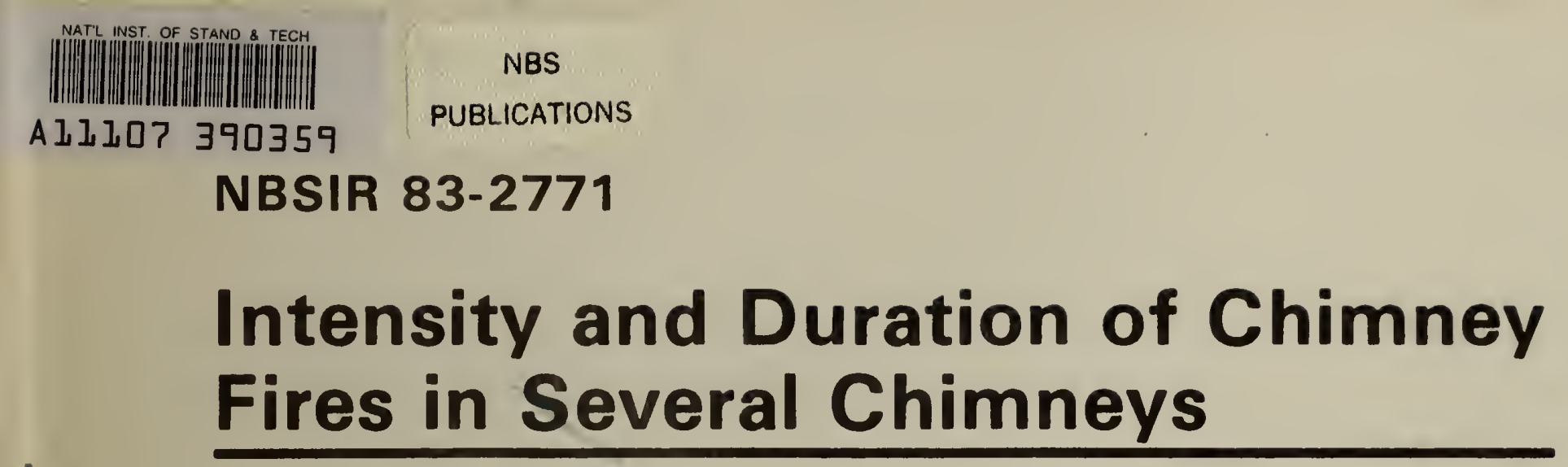

U.S. DEPARTMENT OF COMMERCE

National Bureau of Standards

National Engineering Laboratory

Center for Fire Research

Washington, DC 20234

December 1983

Prepared for:

U.S. Consumer Product Safety Commission

Bethesda, MD 20016

and

U.S. Department of Energy

- CC Washington, DC 20545

100

.456

33-2771

1933

C. 2 


\section{INTENSITY AND DURATION OF CHIMNEY FIRES IN SEVERAL CHIMNEYS}

Richard D. Peacock

U.S. DEPARTMENT OF COMMERCE

National Bureau of Standards

National Engineering Laboratory

Center for Fire Research

Washington, DC 20234

December 1983

Prepared for:

U.S. Consumer Product Safety Commission

Bethesda, MD 20016

and

U.S. Department of Energy

Washington, DC 20545

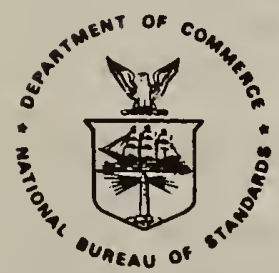

U.S. DEPARTMENT OF COMMERCE, Malcolm Baldrige, Secretary NATIONAL BUREAU OF STANDARDS, Ernest Ambler, Director 

List of Tables $\ldots \ldots \ldots \ldots \ldots \ldots \ldots \ldots \ldots \ldots \ldots \ldots \ldots \ldots \ldots \ldots \ldots \ldots \ldots \ldots \ldots \ldots \ldots \ldots \ldots$ iv

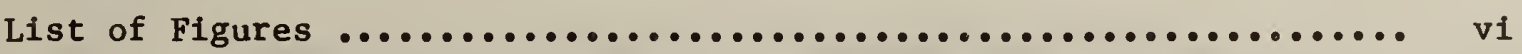

Abstract $\ldots \ldots \ldots \ldots \ldots \ldots \ldots \ldots \ldots \ldots \ldots \ldots \ldots \ldots \ldots \ldots \ldots \ldots \ldots \ldots \ldots \ldots \ldots \ldots \ldots \ldots, \quad$ l

1. INTRODUCTION $\ldots \ldots \ldots \ldots \ldots \ldots \ldots \ldots \ldots \ldots \ldots \ldots \ldots \ldots \ldots \ldots \ldots \ldots \ldots \ldots \ldots$

2. REVIEW OF PREVIOUS WORK ........................... 3

2.1 Fire Incidents Involving Wood-Burning Appliances ........ 3

2.2 Chimney and Connector Construction ................... 4

2.3 Chimney and Chimney Connector Clearances ............... 5

2.4 Temperatures Developed in Heating Appliances ............ 6

2.5 Limiting Safe Temperatures on Combustible Surfaces ....... 7

2.6 Creosoting and Chimney Fires ....................... 9

3. TEST DESIGN AND INSTRUMENTATION $\ldots \ldots \ldots \ldots \ldots \ldots \ldots \ldots \ldots \ldots \ldots \ldots \ldots \ldots . \ldots \ldots$

3.1 Chimney Systems ................................ 10

3.1.1 Chimney Designs .......................... 11

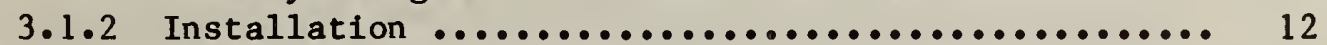

3.2 Appliance Design ................................ 12

3.3 Temperature Control $\ldots \ldots \ldots \ldots \ldots \ldots \ldots \ldots \ldots \ldots \ldots \ldots \ldots \ldots \ldots \ldots \ldots \ldots \ldots$

3.4 Instrumentation $\ldots \ldots \ldots \ldots \ldots \ldots \ldots \ldots \ldots \ldots \ldots \ldots \ldots \ldots \ldots \ldots \ldots \ldots \ldots \ldots \ldots \ldots$

4. FIRING CONDITIONS $\ldots \ldots \ldots \ldots \ldots \ldots \ldots \ldots \ldots \ldots \ldots \ldots \ldots \ldots \ldots \ldots \ldots \ldots$

4.1 Test Procedure, Buildup Tests ........................ 15

4.2 Test Procedure, Burnout Tests ....................... 15

4.3 Test Procedure, Overfire Tests ...................... 16

5. TEST RESULTS $\ldots \ldots \ldots \ldots \ldots \ldots \ldots \ldots \ldots \ldots \ldots \ldots \ldots \ldots \ldots \ldots \ldots \ldots \ldots \ldots \ldots \ldots$

5.1 Buildup Tests ................................ 16

5.2 Burnout Tests $\ldots \ldots \ldots \ldots \ldots \ldots \ldots \ldots \ldots \ldots \ldots \ldots \ldots \ldots \ldots \ldots \ldots \ldots \ldots \ldots \ldots \ldots$

5.3 Overfire Tests .............................. 17

6. BUILDUP TESTS $\ldots \ldots \ldots \ldots \ldots \ldots \ldots \ldots \ldots \ldots \ldots \ldots \ldots \ldots \ldots \ldots \ldots \ldots \ldots \ldots$

7. BURNOUT TESTS $\ldots \ldots \ldots \ldots \ldots \ldots \ldots \ldots \ldots \ldots \ldots \ldots \ldots \ldots \ldots \ldots \ldots \ldots \ldots \ldots \ldots$

7.1 Gas Temperatures .................................. 19

7.2 Chimney Surface Temperatures ....................... 23

7.3 Enclosure Temperatures ............................ 26

7.4 Damage to Chimney Systems ....................... 27

8. OVERFIRE TESTS $\ldots \ldots \ldots \ldots \ldots \ldots \ldots \ldots \ldots \ldots \ldots \ldots \ldots \ldots \ldots \ldots \ldots \ldots \ldots \ldots$

8.1 Maximum Temperatures ............................ 28

8.2 Duration of Elevated Temperatures ................. 30

9. CONCLUSTONS ................................... 30

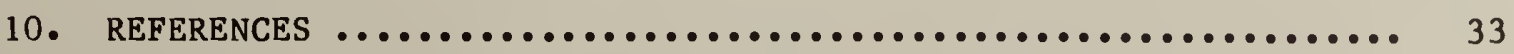


Table 1. Instrumentation for Chimneys 1,2 , and $4 \ldots \ldots \ldots \ldots \ldots . \ldots 37$

Table 2. Instrumentation for Chimney $5 \ldots \ldots \ldots \ldots \ldots \ldots \ldots \ldots \ldots \ldots$

Table 3. Instrumentation for Chimney $3 \ldots \ldots \ldots \ldots \ldots \ldots \ldots \ldots \ldots$

Table 4. Summary of Creosote Burnout Tests in Several Chimneys .... 40

Table 5. Temperature Profiles From Chimney Buildup Test of Chimney 1 ................................ 41

Table 6. Temperature Profiles From Chimney Buildup Test of

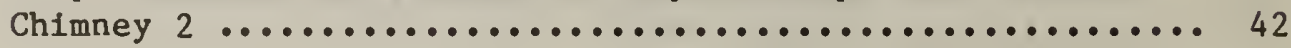

Table 7. Temperature Profiles From Chimney Buildup Test of

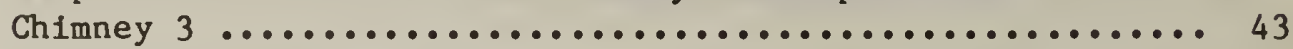

Table 8. Temperature Profiles From Chimney Buildup Test of Chimney 4 .................................. 44

Table 9. Temperature Profiles From Chimney Burnout Test of

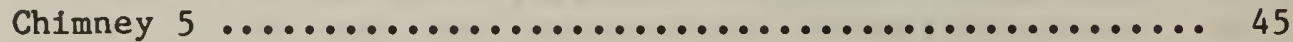

Table 10. Temperature Profiles From Chimney Burnout Test of Chimney 1, Test 1 ........................... 46

Table 11. Temperature Profiles From Chimney Burnout Test of

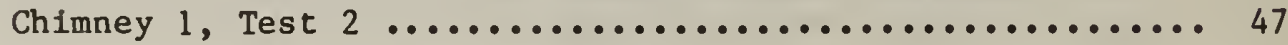

Table 12. Temperature Profiles From Chimney Burnout Test of Chimney 1, Test $3 \ldots \ldots \ldots \ldots \ldots \ldots \ldots \ldots \ldots \ldots \ldots . \ldots . \ldots . \ldots$

Table 13. Temperature Profiles From Chimney Burnout Test of

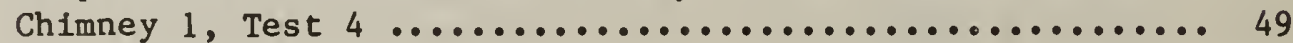

Table 14. Temperature Profiles From Chimney Burnout Test of Chimney 2, Test 5 ........................... 50

Table 15. Temperature Profiles From Chimney Burnout Test of

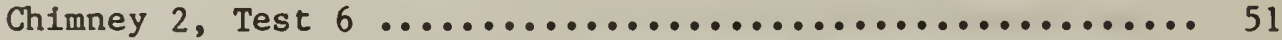

Table 16. Temperature Profiles From Chimney Burnout Test of

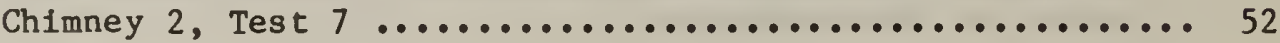

Table 17. Temperature Profiles From Chimney Burnout Test of Chimney 2, Test $8 \ldots \ldots \ldots \ldots \ldots \ldots \ldots \ldots \ldots \ldots \ldots \ldots \ldots . \ldots \ldots$

Table 18. Temperature Profiles From Chimney Burnout Test of

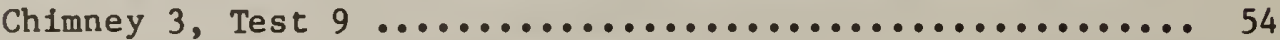


Table 19. Temperature Profiles From Chimney Burnout Test of Chimney 4, Test 10

Table 20. Temperature Profiles From Chimney Burnout Test of Chimney 4 , Test $11 \ldots \ldots \ldots \ldots \ldots \ldots \ldots \ldots \ldots \ldots \ldots \ldots \ldots \ldots$

Table 21. Temperature Profiles From Chimney Burnout Test of Chimney 5 , Test $12 \ldots \ldots \ldots \ldots \ldots \ldots \ldots \ldots \ldots \ldots \ldots \ldots \ldots \ldots$

Table 22. Maximum Temperatures Measured During Several Chimney Fires in Five Different Chimneys ................... 58

Table 23. Temperature Profiles From Chimney Overfire Test of Chimney 1 ................................... 59

Table 24. Temperature Profiles From Chimney Overfire Test of Chimney 2 .................................... 60

Table 25. Temperature Profiles From Chimney Overfire Test of Chimney 3 ..................................... 61

Table 26. Temperature Profiles From Chimney Overfire Test of Chimney 4 ...................................... 62

Table 27. Temperature Profiles From Chimney Overfire Test of Chimney 5 ..................................... 
Figure 1. Installation of Factory-Bu1lt Chimneys 1, 2, and 4

for Ch1mney Fire Tests ....................... 64

Figure 2. Installation of Factory-Bullt Chimney 5 for Chimney

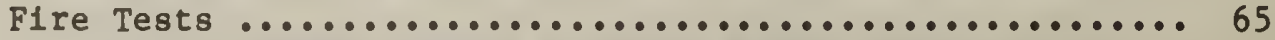

F1gure 3. Installation of Masonry Chimney 3 for Chimney F1re

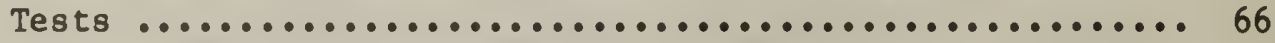

Figure 4. Detalls of the Construction of the Factory-Bullt

Ch1mneys Tested ...............................

F1gure 5. Detalls of the Construction of Combustible Enclosures

Used to Surround Ch1mneys 1 through $4 \ldots . . . \ldots . . . . .668$

F1gure 6. Temperature Control and Appliance A1r Inlet Control

Systems Design .............................. 69

F1gure 7. Instrumentation Locations for Tests of Factory-Bullt

Ch1mneys 1,2 , and $4 \ldots \ldots \ldots \ldots \ldots \ldots \ldots \ldots \ldots \ldots \ldots \ldots$

F1gure 8. Instrumentation Locations for Tests of Factory-Bu1lt

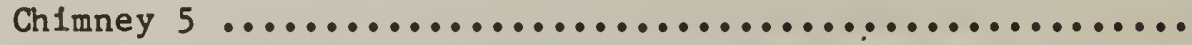

F1gure 9. Instrumentat1on Locat1ons for Tests of Masonry

Ch1mney 3 ................................ 72

F1gure 10. Temperatures at Chlmney Base Durlng Creosoting Bulldup Test of Ch1mney $1 \ldots \ldots \ldots \ldots \ldots \ldots \ldots \ldots \ldots . \ldots \ldots$

F1gure 11. Temperatures at Chimney Base During Creosoting Bulldup

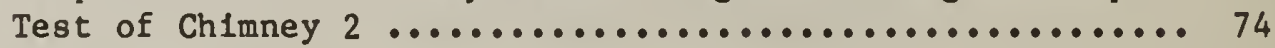

Figure 12. Temperatures at Ch1mney Base During Creosoting Bulldup

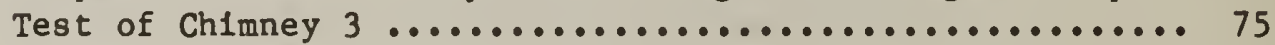

Figure 13. Temperatures at Ch1mney Base Durlng Creosoting Bulldup

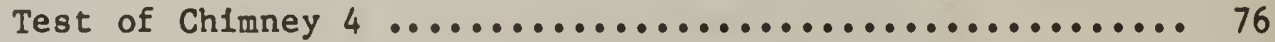

F1gure 14. Temperatures at Chlmney Base Durlng Creosoting Bu1ldup

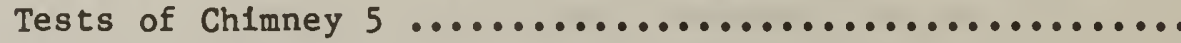

F1gure 15. Temperature Profiles During Creosoting Bulldup Test of Ch1mney 1 ................................... 78

Figure 16. Temperature Profiles During Creosoting Bulldup Test of

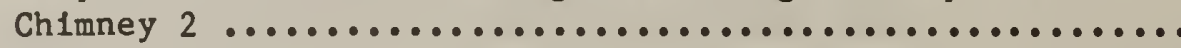


Figure 17. Temperature Profiles During Creosoting Buildup Test of Chimney 3 ................................ 80

Figure 18. Temperature Profiles During Creosoting Buildup Test of Chimney 4 ................................. 81

Figure 19. Temperature Profiles During Creosoting Buildup Test of Chimney 5 ................................

Figure 20. Temperatures at Chimney Base During Burnout of Chimney 1 , Test 1 ......................................

Figure 21. Temperatures at Chimney Base During Burnout of Chimney 1 , Test 2 ................................... 84

Figure 22. Temperatures at Chimney Base During Burnout of Chimney 1 , Test 3 .......................................

Figure 23. Temperatures at Chimney Base During Burnout of Chimney 1 , Test 4 .....................................

Figure 24. Temperatures at Chimney Base During Burnout of Chimney 2, Test 5 .....................................

Figure 25. Temperatures at Chimney Base During Burnout of Chimney 2, Test 6 ......................................

Figure 26. Temperatures at Chimney Base During Burnout of Chimney 2, Test 7 ......................................

Figure 27. Temperatures at Chimney Base During Burnout of Chimney 2 , Test 8 ......................................

Figure 28. Temperatures at Chimney Base During Burnout of Chimney 3, Test 9 ..................................... 91

Figure 29. Temperatures at Chimney Base During Burnout of Chimney 4, Test 10 .....................................

Figure 30. Temperatures at Chimney Base During Burnout of Chimney 4,

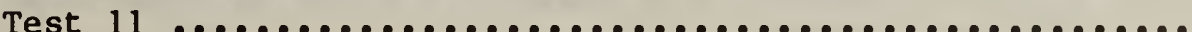

Figure 31. Temperatures at Chimney Base During Burnout of Chimney 5, Test 12

Figure 32. Temperature Profiles During Burnout Test of Chimney 1, Test 1

Figure 33. Temperature Profiles During Burnout Test of Chimney 1 ,

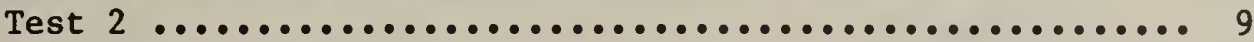

Figure 34. Temperature Profiles During Burnout Test of Chimney 1 , Test 3 
Figure 35. Temperature Profiles During Burnout Test of Ch1mney 1 ,

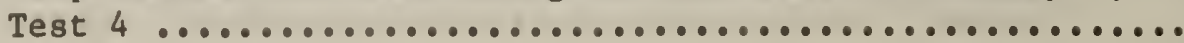

F1gure 36. Temperature Prof1les During Burnout Test of Ch1mney 2,

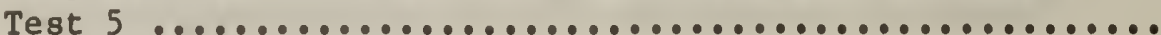

F1gure 37. Temperature Profiles During Burnout Test of Chimney 2,

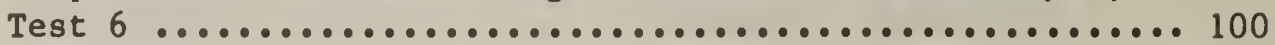

F1gure 38. Temperature Profiles During Burnout Test of Chimney 2,

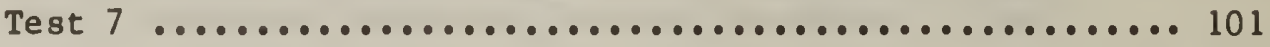

F1gure 39. Temperature Prof1les Dur1ng Burnout Test of Chimney 2,

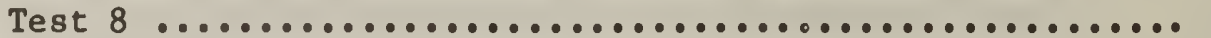

F1gure 40. Temperature Prof1les Dur1ng Burnout Test of Ch1mney 3,

Test 9 .....................................

F1gure 41. Temperature Profiles Dur1ng Burnout Test of Chimney 4,

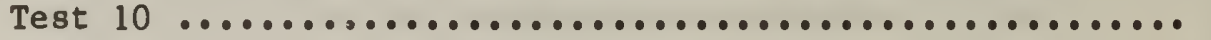

F1gure 42. Temperature Profiles During Burnout Test of Chimney 4,

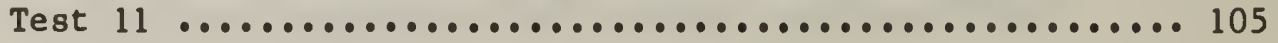

F1gure 43. Temperature Profiles During Burnout Test of Ch1mney 5,

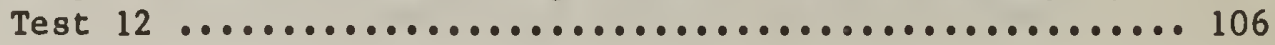

F1gure 44. Duration of Elevated Temperatures Dur1ng Ch1mney Burnout

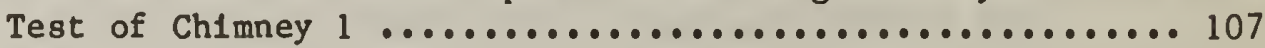

F1gure 45. Duration of Elevated Temperatures Durlng Ch1mney Burnout

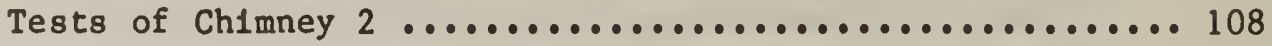

F1gure 46. Duration of Elevated Temperatures During Ch1mney Burnout Tests of Ch1mney 3 .............................. 109

F1gure 47. Duration of Elevated Temperatures During Ch1mney Burnout

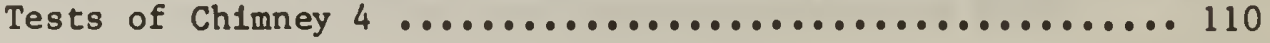

F1gure 48. Duration of Elevated Temperatures Dur1ng Chimney Burnout Test of Ch1mney 5 .............................111

F1gure 49. Duration of Temperatures in Excess of $50^{\circ} \mathrm{C}$ on Enclosure Surfaces During Ch1mney Burnout Tests ................ 112

F1gure 50. Temperatures at Chimney Base Dur1ng Overfire Test of Ch1mney 1 ...................................

F1gure 51. Temperatures at Chimney Base During Overfire Test of

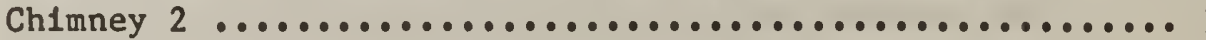

F1gure 52. Temperatures at Ch1mney Base Dur1ng Overfire Test of Ch1mney 3 
Figure 53. Temperatures at Chimney Base During Overfire Test of Chimney 4

Figure 54. Temperatures at Chimney Base During Overfire Test of

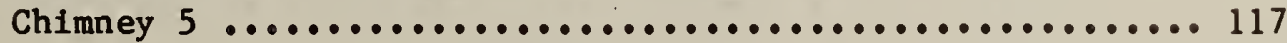

Figure 55. Temperature Profiles During Overfire Test of Chimney $1 \ldots 118$

Figure 56. Temperature Profiles During Overfire Test of Chimney 2 .. 119

Figure 57. Temperature Profiles During Overfire Test of Chimney 3 .. 120

Figure 58. Temperature Profiles During Overfire Test of Chimney 4 .. 121

Figure 59. Temperature Profiles During Overfire Test of Chimney 5 .. 122

Figure 60. Damage to Masonry Chimney 3 After Chimney Fire ........ 123

Figure 61. Damage to Masonry Chimney 3 After Chimney Fire ........ 124

Figure 62. Damage to Factory-Built Chimney 5 After Chimney Fire -Hole in Tee Section at Base of Chimney ............. 125

Figure 63. Damage to Factory-Built Chimney 5 After Chimney Fire Buckling of Stainless Steel Inner Liner ............. 126 

Intensity and Duration of Chimney Fires in Several Chimneys

\section{Richard D. Peacock}

\section{Abstract}

A series of tests was conducted in five instrumented chimneys to study the intensity and duration of chimney fires due to the ignition and burning of combustible deposits accumulated on the chimney lining over a prolonged period of time. These tests were conducted (1) to establish typical conditions including temperatures in the chimneys and on combustible surfaces nearby, (2) to determine the duration of the burnout as evidenced by elevated temperatures within the chimneys, and (3) to compare these measured values with those obtained during overfire conditions - prolonged firing of the appliances at high rates.

The results of these tests point out some areas where the codes and standards covering residential wood heating appliances should be modernized to better protect against fallure due to chimney fires.

Key words: Chimney fires; chimneys; creosote; fire safety; fire tests; flues; heating equipment; stoves; wood.

\section{INTRODUCTION}

The U.S. Department of Energy (DOE) and the U.S. Consumer Product Safety Commission (CPSC), as part of a program to investigate safety risks involved with the use of solid-fuel burning appliances, have sponsored experimental studies at the Center for Fire Research (CFR) at the National Bureau of Standards (NBS) to identify some of the hazards associated with solid-fuel heating, to provide information to improve safety practices for the use of the appliances, and to provide data forming the basis for improved codes and standards.

During the first year of the program, an accident survey, literature review, and codes and standards analysis were performed to establish accident 
patterns, to determine the types of risks involved with the use of woodburning appliances, and to ascertain the adequacy of existing codes and standards in addressing these risks $[1-3]^{1}$. Overwhelmingly, conditions related to installation, operation, and maintenance were responsible for the fire incidents studied. Only a small percentage of the fires was attributed to product design or product defects. Thus, the safe installation and use of wood-burning appliances is a critical requirement for preventing fire accidents involving the equipment. Most of the criteria for the installation and use of wood-burning appliances are based upon data developed over 40 years ago and do not provide information on materials of construction, or appliances avallable in the current market.

The present research program at CFR includes research on:

- clearances to combustibles from appliances and chimney connectors;

- methods of protection to allow reduced clearances to walls and ceilings;

- temperatures developed in and around fireplaces whth and without fireplace inserts installed;

- intensity and duration of chimney fires in factory-built and masonry chimneys; and

- temperatures on combustible material surrounding chimney connectors passing through walls and/or connecting to chimneys.

This report, one of a series of reports providing information from the DOE/CPSC sponsored experimental program on wood-burning safety at NBS, presents the results of fire tests conducted on a number of chimneys, of both factory-bullt and masonry design. The tests were conducted to establish maximum temperatures and duration of these elevated temperature levels during

Numbers in brackets refer to literature references listed in section 10 at the end of this report. 
creosote burnouts in chimneys serving wood-burning appliances. The intended uses of these data are to define appropriate levels for testing of chimneys to simulate chimney fires and to provide information for improved construction requirements for masonry chimneys.

\section{REV IEW OF PREVIOUS WORK}

\subsection{Fire Incidents Involving Wood-Burning Appliances}

Recent statistics on fires and injuries related to wood-burning appliances are alarming:

\begin{tabular}{ccccc} 
Year & Fires & $\begin{array}{c}\text { Percent } \\
\text { Change }\end{array}$ & Deaths & $\begin{array}{c}\text { Dollar } \\
\text { Loss }\end{array}$ \\
\hline 1978 & 66,800 & & 250 & $\$ 134$ million \\
1979 & 70,700 & $+14 \%$ & 210 & $\$ 175$ million \\
1980 & 112,000 & $+58 \%$ & 350 & not available \\
1981 & 130,100 & $+16 \%$ & 290 & $\$ 265$ million \\
\hline
\end{tabular}

Source: National Fire Protection Association, U.S. Fire Administration, U.S. Consumer Product Safety Commission/EPHA

There were more fires in solid-fuel burning equipment, and a larger percentage increase over previous years, than were reported for any other kind of heating equipment - including gas, electric, and oil-burning appliances [4,5]. A recent analysis indicated wood-burning appliances were the third leading cause of multiple deaths from fires in residential properties from 1971 to 1980 [6]. Clearly, accidental fires from wood-burning appliances are an increasingly important problem.

In a study of the hazards associated with the use of wood or coal-burning stoves by the U.S. Consumer Product Safety Commission, chimneys, flues, or chimney connectors were identified as a leading cause of fires [7]. In 1981, out of an estimated 130,100 fires involving heating equipment, 52,000, or about 40 percent, were attributed to chimneys, flues or chimney connectors. About 85 percent $(44,700)$ of these fires were from chimneys and flues and about 15 percent $(7,900)$ from chimney connectors [4]. An earlier study by NBS 
presented an analysis of fire incident data related to wood-burning appliances [1-2,8]. Product malfunctions, construction defects, design deficiencies, or worn out equipment were attributed to be the cause in only 13 percent of the solid fuel related fires recorded in the U.S. Fire Administration data base. overwhelmingly, conditions related to the installation, operation, or maintenance of the appliances were reported as responsible for the fires. Shelton $[3,9]$ supports this conclusion with studies in the state of Massachusetts and from an insurance company in Wisconsin. A breakdown of solid fuel appliance related fire incidents by probable cause and by equipment type indicates that except for improper maintenance, the appliances themselves were involved in most of the fires rather than chimneys or chimney connectors -- over 70 percent in these cases [8]. However, under the category of improper maintenance, appliances were involved in only 26 percent of the recorded fires. Improper maintenance is the significant problem associated with chimneys and chimney connectors.

\subsection{Chimney and Connector Construction}

Recommendations for minimum construction specifications for masonry chimneys and chimney connectors are available in the various model building codes [10-17]. A fire-clay flue liner, $16 \mathrm{~mm}$ (5/8 in) thick, is surrounded by a masonry wall of solid masonry units not less than $102 \mathrm{~mm}$ ( 4 in) in thickness, or of reinforced portland or refractory cement concrete at least $102 \mathrm{~mm}$ (4 in) thick or of rubble stone masonry not less than $305 \mathrm{~mm}$ (12 in) thick. The flue liner is separated from the chimney wall by an air space.

For factory-built chimneys, performance based specifications are available in standards used for testing and listing of chimneys [18]. The standards specify maximum operating temperatures for the chimneys during normal and overfire conditions, maximum allowable temperatures on chimney and surrounding combustible surfaces, and structural requirements for the chimneys. In addition complete installation and operation instructions are required. 


\subsection{Chimney and Chimney Connector Clearances}

Clearances to combustible materials for chimneys and chimney connectors are also specified in the various model codes [10-17]. For simplicity and ease of enforcement, a single, hopefully conservative clearance is given for each type of chimney and chimney connector. For residential solid fuel chimneys, typically $51 \mathrm{~mm}$ (2 in) of clearance is required. Chimney connectors for solid fuel burning residential appliances require a clearance of at least $0.46 \mathrm{~m}$ (18 in) to combustible materials. However, by protecting combustible material, these clearances may be reduced.

The experimental basis for these code requirements is not, however, quite so clear. Several experimental studies have been carried out to determine minimum acceptable clearances to combustible materials. Voigt [19], in a 1933 publication, recommends a minimum clearance of $0.30 \mathrm{~m}$ (12 in) for chimney connectors $0.23 \mathrm{~m} \mathrm{(} 9 \mathrm{in}$ ) in diameter. A more extensive study, performed by Underwriters Laboratories in 1943 [20], presents minimum safe clearances for both unprotected surfaces and surfaces protected by various methods. Distances at which a maximum temperature rise of $50^{\circ} \mathrm{C}\left(90^{\circ} \mathrm{F}\right)$ above room temperature is reached are presented as a function of the temperature of the exposed face of a heat producing appliance. The relative protection afforded by various materials used as heat barriers between the appliance and combustible surface is also examined. Lawson, Fox, and Webster [21] and Lawson and Simms [22] have studied the heating of wall panels and wood by radiation. With experimentation and theoretical predictions, they present safe clearances between flue pipes and wall surfaces as a function of the pipe diameter and the pipe surface temperature. To maintain a maximum wall temperature of $100^{\circ} \mathrm{C}$ $\left(212^{\circ} \mathrm{F}\right)$, a $0.15 \mathrm{~m}(6 \mathrm{in})$ pipe should not exceed $350^{\circ} \mathrm{C}\left(660^{\circ} \mathrm{F}\right)$ in surface temperature at a clearance of $0.46 \mathrm{~m}$ (18 in) [21].

These experimental studies established limits for two important parameters: appliance surface temperature and clearance to combustibles for unprotected and protected surfaces. Maximum appliance surface temperature for the appliances studied ranged from 300 to $350^{\circ} \mathrm{C}\left(600\right.$ to $\left.660^{\circ} \mathrm{F}\right)$. Minimum safe wall clearance for unprotected surfaces range from $0.3 \mathrm{~m}$ to $0.91 \mathrm{~m}$ (12 in to $36 \mathrm{in})$. Most of the current code provisions are only adequate for maximum appliance surface temperatures up to 300 to $350^{\circ} \mathrm{C}$. 


\subsection{Temperatures Developed in Heating Appliances}

Tests made with prefabricated porcelain-enameled metal chimneys for solid or liquid fuel furnaces $[23,24]$ established a limiting temperature rise of $190^{\circ} \mathrm{C}\left(375^{\circ} \mathrm{F}\right)$ on the outer surface of the chimney for a flue gas temperature of $540^{\circ} \mathrm{C}\left(1000^{\circ} \mathrm{F}\right)$. With this limitation, wood framing spaced $51 \mathrm{~mm}(2 \mathrm{in})$ or more away from the chimney was considered safe. Satisfactory insulation of the chimneys to reduce the outer surface temperatures to acceptable levels was obtalned with asbestos paper plies totaling about $45 \mathrm{~mm}$ ( $13 / 4 \mathrm{in}$ ) in thickness. In the same study, some asbestos-cement pipe coverings also were found to be capable of reducing heat transmission to the extent required for safety of nearby combustibles.

To establish performance requirements for lightwelght prefabricated chimneys, tests were conducted with lined and unlined masonry chimneys having $102 \mathrm{~mm}$ (4 in) thick walls [25]. Temperatures in excess of $50^{\circ} \mathrm{C}\left(90^{\circ} \mathrm{F}\right)$ above ambient on wood framing spaced $51 \mathrm{~mm}$ ( 2 in) away from the chimney were noted with a steady-state flue gas temperature of $480^{\circ} \mathrm{C}\left(900^{\circ} \mathrm{F}\right)$ for the unlined chimney and $590^{\circ} \mathrm{C}\left(1100^{\circ} \mathrm{F}\right)$ for the lined chimney. However, these hazardous conditions were not reached in the lined chimney tests until after 13 hours. In order to study operating conditions with typical fuels, a number of firing tests [26] were conducted with heating appliances known to give high flue gas temperatures, using wood and soft coal as fuels. With a coal-fired, jacketed type heater, gas temperatures ranging from $650^{\circ} \mathrm{C}$ to $705^{\circ} \mathrm{C}\left(1200^{\circ} \mathrm{F}\right.$ to $\left.1300^{\circ} \mathrm{F}\right)$ were measured for an hour or more in the flue at the celling level above the heater. Thus, temperatures in excess of safe limits can be produced for extended periods of time.

Lawson, et al. [21] present the results of tests to measure surface temperatures of the flue plpes to validate theoretical predictions. Measured for a variety of flue systems using solid fuels--mostly coal and coke--they report temperatures of about $148^{\circ} \mathrm{C}\left(300^{\circ} \mathrm{F}\right)$ under "normal conditions" and temperatures as high as $815^{\circ} \mathrm{C}\left(1500^{\circ} \mathrm{F}\right)$ under overload conditions.

Fox and Whittaker [26] report temperatures on metal flues of several heating appliances over a range likely to be encountered in normal use. 
Maximum flue pipe surface temperatures ranged from 700 to $815^{\circ} \mathrm{C}$ (1300 to $\left.1500^{\circ} \mathrm{F}\right)$ at the appliance flue outlet, 360 to $510^{\circ} \mathrm{C}\left(680\right.$ to $\left.950^{\circ} \mathrm{F}\right)$ at a distance of $1 \mathrm{~m}\left(3 \mathrm{ft}\right.$ ) from the appliance flue outlet and 280 to $330^{\circ} \mathrm{C}(550$ to $\left.620^{\circ} \mathrm{F}\right)$ at a distance of $2 \mathrm{~m}(6 \mathrm{ft})$ from the appliance flue outlet.

Shoub [23] concludes that combustible materials will be ignited if maintained in continued contact with a chimney of $121 \mathrm{~mm}$ ( $43 / 4 \mathrm{in}$ ) wall thickness and with flue gas temperatures of $400^{\circ} \mathrm{C}\left(750^{\circ} \mathrm{F}\right)$.

Current test procedures for prefabricated chimneys require testing of chimney assemblies with hot flue gases [27]. Flue gas temperatures of $540^{\circ} \mathrm{C}$ $\left(1000^{\circ} \mathrm{F}\right)$ are maintained until steady-state conditions are reached, followed by $760^{\circ} \mathrm{C}\left(1400^{\circ} \mathrm{F}\right)$ for 1 hour and $925^{\circ} \mathrm{C}\left(1700^{\circ} \mathrm{F}\right)$ for 10 minutes. These conditions are intended to simulate worst-case conditions.

In tests for the U.S. Department of Energy, maximum surface temperatures ranging from 212 to $456^{\circ} \mathrm{C}\left(414\right.$ to $\left.853^{\circ} \mathrm{F}\right)$ were recorded on single wall chimney connectors. The average maximum surface temperature for seventeen tests of five different appliances was $375^{\circ} \mathrm{C}\left(707^{\circ} \mathrm{F}\right)$. Flue gas temperatures ranging from 600 to $800^{\circ} \mathrm{C}\left(1100\right.$ to $\left.1475^{\circ} \mathrm{F}\right)$ were noted at the appliance flue outlet. Further downstream at $2 \mathrm{~m}(6 \mathrm{ft})$ from the appliance flue outlet, flue gas temperatures dropped to 400 to $550^{\circ} \mathrm{C}\left(750\right.$ to $\left.1020^{\circ} \mathrm{F}\right)[8]$.

\subsection{Limiting Safe Temperatures on Combustible Surfaces}

Listings of chimneys for heat producing appliances by nationally recognized testing laboratories and methods for setting clearances between chimneys and combustible surfaces are based on temperature rises on combustible surfaces of: 
Maximum Temperature R1se

$\begin{array}{cccc}\text { Firing Condition } & \text { Flue Gas } & \text { Exposed } & \text { Unexposed } \\ \text { Temperature } & \text { Surface } & \text { Surface } \\ \left({ }^{\circ} \mathrm{C} /{ }^{\circ} \mathrm{F}\right) & \left({ }^{\circ} \mathrm{C} /{ }^{\circ} \mathrm{F}\right) & \left({ }^{\circ} \mathrm{C} /{ }^{\circ} \mathrm{F}\right)\end{array}$

$\begin{array}{lccr}\text { Continuous firing at } & 538 / 1000 & 65 / 117 & 50 / 90 \\ 1 \text { hour overload at } & 760 / 1400 & 78 / 140 & 78 / 140 \\ 10 \text { min overload at } & 927 / 1700 & 97 / 175 & 97 / 175 \\ 3-10 \text { min overloads at } & 1149 / 2100 & 97 / 175 & 97 / 175\end{array}$

Source: U 103 and UL 1482 (references [18] and [28]).

These requirements are based on the fact that, while the 1gnition temperature of wood products 18 generally quoted to be on the order of $200^{\circ} \mathrm{C}\left(400^{\circ} \mathrm{F}\right)$ [8], wood that is exposed to constant heating over a perlod of time may undergo a chemical change resulting in a much lower ignition temperature and increased potential for self-ignition [28].

Mitchell [30] presents data on wood fiberboard exposed to temperatures as low as $109^{\circ} \mathrm{C}\left(228^{\circ} \mathrm{F}\right)$ that resulted in ignition after an exposure of several months. MacLean $[31,32]$ reports charring of wood samples at temperatures as low as $93^{\circ} \mathrm{C}\left(200^{\circ} \mathrm{F}\right)$ after longer exposures. He concludes that wood should not be exposed to temperatures appreciably higher than $66^{\circ} \mathrm{C}\left(150^{\circ} \mathrm{F}\right)$ for long periods. McGuire [33], suggests that the maximum safe temperature on the surface of a combustible material adjacent to a constant heat source should be no more than $100^{\circ} \mathrm{C}\left(212^{\circ} \mathrm{F}\right)$.

Clearly, the ignition of wood at moderately elevated temperatures is a complex phenomenon. The time of exposure is indeed an 1mportant parameter [34]. While exact 1 imits recommended in the literature vary due to exposure time and detalls of the tests conducted, the numerous documented fires involving the ignition of wood members near low pressure steam pipes [35] suggest an upper temperature $11 \mathrm{mit}$ for wood exposed to long-term low-level heating should not be appreclably higher than $100^{\circ} \mathrm{C}\left(212^{\circ} \mathrm{F}\right)$. 


\subsection{Creosoting and Chimney Fires}

Published literature related to creosoting and chimney fires is scarce. A brief review of efforts to characterize chimney creosoting is included below.

The term "creosote" is used in several different ways in relation to wood heating. It may refer to whatever accumulates in a chimney or chimney connector attached to a wood-burning appliance, such as tar, liquids, and soot; or to the tar and liquids only; or to the liquids only; or to one particular compound in the liquid [9]. For the purposes of this study, a definition by Shelton [9] is appropriate: "everything in the chimney that might burn or need cleaning, but excluding such things as birds' nests."

Flink [36] presents the results of a number of chimney fire tests conducted to establish test criteria for factory-built chimneys. He reports two regimes of burning during a chimney fire. In all cases of artificially produced chimney fires, a primary fire with flue gas temperatures of $971^{\circ} \mathrm{C}$ $\left(1780^{\circ} \mathrm{F}\right)$ is followed by up to four secondary fires resulting in a rise in the gas temperature during the successive secondary fires to as high as $1166^{\circ} \mathrm{C}$ $\left(2130^{\circ} \mathrm{F}\right)$. Outer chimney surface temperatures of approximately $260^{\circ} \mathrm{C}\left(500^{\circ} \mathrm{F}\right)$ were noted.

Stone [37] notes peak flue gas temperatures from $717^{\circ} \mathrm{C}\left(1322^{\circ} \mathrm{F}\right)$ to $806^{\circ} \mathrm{C}$ $\left(1483^{\circ} \mathrm{F}\right)$ during two chimney fire tests. He concludes that igniting chimney fires under controlled conditions may prevent creosote buildup from becoming too dangerous, while not creating unsafe temperatures on surrounding combustibles.

Studies at Auburn University present interesting insights into the buildup of creosote deposits prior to a chimney fire [38-40]. Eighteen different tests were performed on one chimney using three different types of wood (hickory, oak, and yellow pine), each with three different wood geometries. Tests were also performed using different moisture levels. The wood type, moisture content, and geometry did affect the creosote formation by the stove used in the tests. Dry wood produced slightly more creosote than wet wood. 
Hardwoods, such as hickory and oak, produced more creosote than yellow pine. However, in all tests, significant amounts of creosote were generated.

\section{TEST DESIGN AND INSTRUMENTATION}

The work reported herein consists of a series of tests conducted with five different chimneys for residential solid-fuel appliances. The tests were designed to provide data on the intensity and duration of chimney fires in chimneys serving wood-burning appliances. Five different chimneys were studied: four factory-bullt chimneys and one masonry chimney. Areas of interest included:

- temperatures developed on chimney surfaces and on surrounding combustibles,

- temperatures developed in the flue gas,

- duration of elevated temperatures in the chimney and on surrounding combustible surfaces, and

- structural integrity of the chimney--does any fallure occur in the chimney as a result of the chimney fire that leads to unsafe conditions?

\subsection{Chimney Systems}

Five different chimney systems were selected by their design as being representative of those avallable in the marketplace. Obviously, with many manufacturers of factory-bullt chimneys and an almost infinite variety of masonry chimneys, it would be impossible to test every varlation. However, the chimneys used represent a selection of those on the market. A description of each chimney is included below. Figures 1 to 3 show the experimental setup used during the testa of the factory-built chimneys and the masonry chimney. Figures 4 and 5 provide detalls of construction of the chimneys. 


\subsubsection{Chimney Designs}

Chimney 1 is a $0.15 \mathrm{~m}$ (6 in) inside diameter air-insulated factory-built chimney constructed of three concentric metal pipes, each separated by an air space. The inside pipe is of stainless steel and the center and outer pipe $(0.20 \mathrm{~m} / 8$ in and $0.25 \mathrm{~m} / 10$ in in diameter) are of aluminized and galvanized steel, respectively. The three pipes are held in place by four spacers at the ends of each chimney section. The entire chimney is capped at the ends to minimize the air circulation both along the length of the chimney and between the two air spaces formed by the walls of the chimney. Total chimney height is $3 \mathrm{~m}$ (10 ft) plus $1.8 \mathrm{~m}$ ( $6 \mathrm{ft}$ ) of single-wall steel chimney connector between the appliance outlet and the chimney inlet. The chimney is a listed unit.

Chimney 2 is a $0.15 \mathrm{~m}$ (6 in) inside diameter solid-packed factory-built chimney. Outside diameter of the chimney was $0.20 \mathrm{~m}$ ( $8 \mathrm{in}$ ). High temperature insulation separates the inner chimney wall of stainless steel and the outer chimney wall of aluminum coated steel. Total chimney height is $3 \mathrm{~m}$ ( $10 \mathrm{ft}$ ) plus $1.8 \mathrm{~m}$ ( $6 \mathrm{ft}$ ) of single-wall steel chimney connector between the appliance outlet and the chimney inlet. The chimney system is a listed unit.

Chimney 3 is a masonry chimney constructed to minimum building code requirements. A nominal $0.3 \mathrm{~m} \times 0.3 \mathrm{~m}$ (12 in $\mathrm{x} 12 \mathrm{in}$ ) fireclay flue liner is encased by a single course of nominal $0.1 \mathrm{~m}$ ( $4 \mathrm{in}$ ) wide common brick. The flue liner was separated from the brick by a minimum $25 \mathrm{~mm}$ ( 1 in) air space. Total height of the masonry chimney was $3.5 \mathrm{~m}(12 \mathrm{ft})$ plus $0.9 \mathrm{~m}(3 \mathrm{ft})$ of single wall chimney connector between the appliance outlet and the chimney inlet.

Chimney 4 is a $0.15 \mathrm{~m}$ (6 in) inside diameter solid-packed factory-built chimney similar to chimney 2. Both chimney walls are of stainless steel and the chimney sections join differently than those of chimney 2. Height and connection are the same as chimney 2. The chimney is a listed unit. Chimney 4 was selected because it was identified in accident data as being involved in a large number of fires. 
Chimney 5 is a $0.2 \mathrm{~m}$ (8 in) inside diameter solid-packed factory-built chimney of a design identical to chimney 4 (except for the chimney diameter). Total chimney height was $5.6 \mathrm{~m}(18.4 \mathrm{ft})$ plus $1.2 \mathrm{~m}(4 \mathrm{ft})$ of single-wall steel chimney connector between the appliance outlet and the chimney inlet. The chimney is a listed unit.

\subsubsection{Installation}

The four factory-bullt chimney systems were installed with clearances to combustible materials as recommended by the manufacturer. Typically, the minimum clearance to combustibles was specified as $50 \mathrm{~mm}(2 \mathrm{in})$. For chimney 2 , however, a clearance of $25 \mathrm{~mm}$ ( 1 in) was allowed where the chimney passed through walls and cellings with the use of a chimney support/radiation shield. The masonry chimney was installed with a clearance of $25 \mathrm{~mm}$ ( $1 \mathrm{in}$ ) to combustible materials, consistent with minimum recommendations in model building codes.

An enclosure of $13 \mathrm{~mm}(1 / 2 \mathrm{in})$ thick exterior grade plywood was constructed around chimneys 1 through 4 surrounding these chimneys on all sides. The enclosure began at the base of the chimney, encased the chimney for $2.4 \mathrm{~m}$ ( $8 \mathrm{ft}$ ) vertically, and was closed at both ends with typical floor and celling construction. Detalls of the enclosure are presented in figure 5. Chimney 5 was installed without an enclosure and exposed to outside conditions throughout the test series.

\subsection{Appliance Design}

Two different wood-burning appliances were used during the creosote buildup tests. The appliances were chosen as two different designs (radiant and convective types) and sizes. Construction details are described below.

Appliance 1 is a small radiant room heater constructed of $6.4 \mathrm{~mm}(1 / 4 \mathrm{in})$ and $8 \mathrm{~mm}(5 / 16 \mathrm{in})$ plate steel for the top, sides, and bottom of the appliance. The inside of the firechamber is lined with fire brick refractory. The door is cast iron with a single draft inlet and draft control knob to adjust the intensity of the fire. A $0.15 \mathrm{~m}$ ( $6 \mathrm{in}$ ) diameter flue collar projects out 
the back of the unit and sheet steel bottom heat shield is attached to block radiation from the appliance to the floor surface. The appliance was $46 \mathrm{~cm}$ long by $37 \mathrm{~cm}$ high by $65 \mathrm{~cm}$ wide $\left(18 \times 14 \frac{1}{2} \times 25 \frac{1}{2}\right.$ in) with a hearth area of $1250 \mathrm{~cm}^{2}\left(194 \mathrm{in}^{2}\right)$.

Appliance 2 is a circulating or convective type room heater, a radiant room heater with an exterior cabinet allowing air circulation around the appliance. The firebox is constructed of cast iron and the cabinet of sheet steel. A thermostatically controlled damper regulates the air supply for combustion. Wood inside the unlined firebox rests on a grate with an ash pan and ash door below for removal of ashes. The flue collar attachment for a $0.15 \mathrm{~m}$ ( $6 \mathrm{in}$ ) diameter flue is on the back of the appliance. The appliance was larger than appliance 1 , measuring $53 \mathrm{~cm} \times 89 \mathrm{~cm} \times 54 \mathrm{~cm}$ (21 in $\times 35$ in $\times$ $21 \mathrm{in}$ ) with a hearth area of $2280 \mathrm{~cm}^{2}\left(353 \mathrm{in}^{2}\right)$.

\subsection{Temperature Contro1}

For the creosote buildup tests, the temperature of the flue gas entering the chimney was maintained within preset limits in order to 1) prevent the gas temperature from rising enough to ignite the deposits in the chimney, 2) to keep flue gas temperatures low to promote creosote production, and 3) to allow unattended operation of the appliances. Thus, when the flue gas temperature fell below a predetermined lower limit, the draft inlet on the appliance was opened fully and when the temperature rose above a second predetermined limit, the draft inlet on the appliance was closed completely. A dual set point temperature controller was used with relay outputs and associated electronics to power a linear stepping motor to open or close the draft inlet of the appliance. Limit switches were installed on the appliance draft inlet to sense when the inlet was fully open or fully closed and protect the motor from burnout. The control temperature was measured approximate1y $0.25 \mathrm{~m}$ (10 in) from the base of the chimney. Figure 6 illustrates the temperature control circuitry. 


\subsection{Instrumentation}

The appliances, chimney connector, and chimney were instrumented to measure conditions throughout the tests. All instrument data were automatically recorded at regular intervals on a digital data acquisition system.

Twenty-four-gauge chromel-alumel thermocouples were used to measure temperatures on appliance surfaces, chlmney surfaces and on the face of combustible surfaces adfacent to the chimneys. Flue gas temperatures were monitored with shlelded 24-gauge thermocouples mounted in the center of the flue. Thermocouples were placed in the flue gas, on the inside wall of the chimney, on the outside wall of the chimney, and at four locations on the enclosure approximately every $0.3 \mathrm{~m}$ ( $1 \mathrm{ft}$ ) for the entire helght of the chimney. Thermocouple locations for the factory-bullt chimneys are indicated in tables 1 and 2 as well as in flgures 7 and 8 . Locations of thermocouples in the masonry chimney are shown in table 3 and flgure 9.

\section{FIRING CONDITIONS}

A total of 19 experiments were conducted on the five different chimneys previously described. Typically, three types of experiments were conducted with each chimney--a creosote buildup test, a creosote burnout test, and an overfire test. The creosote bulldup test consisted of a lengthy firing (from one week to several months) at low burning rates (controlling the flue gas temperature) to generate and deposit creosote on the lining of the chimney. Detalls of one day's bulldup in each of the five chimneys is provided in this report. A creosote burnout test followed the perlod of creosote buildup. After the deposits were ignited, the chimney fire was allowed to burn until it burned out. No attempt was made to extinguish the fires. Several burnout tests were conducted on each chimney. For ease of discussion, the tests were assigned a test number, one through twelve. Test results are presented with these test numbers. Data acquisition continued until maximum temperatures were reached. The overfire tests, prolonged firing at high burning rates, were conducted for comparison of maximum temperatures during a chimney fire with those during extreme firing of a clean chimney. The test lasted as long as necessary to reach maximum temperatures. 
In table 4, detalls of the twelve burnout tests are presented. Also detailed in table 4 are the length of the buildup prior to each burnout test and the amount of wood burned.

\subsection{Test Procedure, Buildup Tests}

Using the temperature controllers described earlier allowed continuous operation of the appliances for 24 hours per day, five days per week. Each appliance was charged with wood in the morning, refueled as necessary during the day and fully loaded in the evening for overnight burning. Typically, the flue gas temperature was maintained between $80^{\circ} \mathrm{C}\left(176^{\circ} \mathrm{F}\right)$ and $100^{\circ} \mathrm{C}\left(212^{\circ} \mathrm{F}\right)$ for the duration of the buildup tests. From table 4 , an average of $1.6 \mathrm{~kg} / \mathrm{hr}$ ( $3.6 \mathrm{lb} / \mathrm{hr}$ ) of wood was burned in the buildup experiments. The amount of wood consumed was, of course, dependent upon the appliance size. Since the experiments were conducted in a conditioned laboratory space, the effect of variations in outside air temperature was minimal. Periodically, the chimney connector pipes were removed to examine the progress of the buildup. Table 4 provides the thickness of buildup at the base of the chimney prior to each burnout test.

\subsection{Test Procedure, Burnout Tests}

Following the lengthy buildup period, the deposits in the chimney were ignited and allowed to burn until it was evident that maximum temperatures had been reached. To ignite the creosote deposits, a large hot fire was built in the appliance firebox to ralse the flue gas temperature (and the temperature of the deposits) high enough to lead to ignition of the creosote. Typically temperatures in excess of $650^{\circ} \mathrm{C}$ to $725^{\circ} \mathrm{C}\left(1170^{\circ} \mathrm{F}\right.$ to $\left.1300^{\circ} \mathrm{F}\right)$ were obtained at the appliance outlet before ignition of the deposits was evident. Once it was apparent that the creosote had ignited, all wood was removed from the firebox to observe the effects of the chimney fire alone. The fire was allowed to burn until it died out naturally. Data were recorded until temperatures on surrounding combustibles reached maximum levels and began to decrease. For chimneys 1 to 4 , ambient conditions surrounding the chimneys was controlled to about 20 to $24^{\circ} \mathrm{C}\left(68\right.$ to $\left.75^{\circ} \mathrm{F}\right)$ for the tests. 
For chimney 5, outside alr temperature at the beginning of the test was $-6^{\circ} \mathrm{C}\left(21^{\circ} \mathrm{F}\right)$. As with the other burnout tests, the deposits were 1gnited with a large hot fire on the firebox. Once it was apparent that the deposits had 1gnited, all wood was removed from the firebox to observe the effects of the chimney fire alone. For the first 100 minutes of the test, the fire was mainly confined to the chimney connector, with little burning in the chimney. Upon investigation (by removal of the bottom plate of the Tee) the reason for this became obvious - deposits from the upper levels of the chimney had fallen to nearly totally block the chimney at the Tee. After dislodging the blockage at the Tee, an intense fire in the chimney ensued.

\subsection{Test Procedure, Overfire Tests}

Underwriters Laboratorles standard 1482 for solid fuel burning room heaters provides guidelines for testing wood-burning appliances [28]. In the "brand-fire test," specially constructed, oven-dry douglas fir brands are added at $71 / 2$ minute intervals after ignition unt11 it is apparent that maximum temperatures have been reached. The brands are constructed as two crossed layers of nominal $25 \mathrm{~mm}$ ( 1 in) douglas fir spaced $25 \mathrm{~mm}$ ( 1 in) apart on center. Each brand is sized (width $x$ length) to be approximately $1 / 3$ the area of the hearth of the appliance.

\section{TEST RESULTS}

\subsection{Bufldup Tests}

Measurements of flue gas temperature, chimney surface temperatures, and enclosure temperature at the base of the chimney during a day of typical buildup are shown in figures 10 to 14 for the five chimneys studied. Average temperatures over the entire duration of the tests are presented in tables 5 to 9 and figures 15 to 19 as profiles of temperature through the entire height of the flue. 


\subsection{Burnout Tests}

Measurements of flue gas temperature, chimney surface temperatures, and enclosure temperature at the base of the chimney during the twelve burnout tests are presented in figures 20 to 31 for the five chimneys studied. Maximum temperatures over the entire duration of the tests are presented in tables 10 to 21 and figures 32 to 43. The duration of these elevated temperatures is presented in figures 44 to 48 as the amount of time during the test the temperature of the flue gas or chimney wall temperature was above given levels. The duration of time the enclosure temperature exceeded a level of $50^{\circ} \mathrm{C}\left(90^{\circ} \mathrm{F}\right)$ above ambient temperature is shown in figure 49 . Table 22 summarizes the temperature levels attained in the tests.

\subsection{Overfire Tests}

Measurements of flue gas temperature, chimney surface temperatures, and enclosure temperature at the base of the chimney during the five overfire tests are shown in figures 50 to 54. Maximum temperatures over the entire duration of the tests are presented in figures 55 to 59 and in tables 23 to 27.

\section{BUILDUP TESTS}

Temperature profiles during the buildup tests on the five chimneys (figures 15 to 19) were understandably similar due to the controlled flue gas temperature. The average temperatures at the base of the chimneys were:

\begin{tabular}{ccccc} 
Chimney & Gas & Inner Lining & Outer Surface & Enclosure \\
\hline & $\left({ }^{\circ} \mathrm{C} /{ }^{\circ} \mathrm{F}\right)$ & $\left({ }^{\circ} \mathrm{C} /{ }^{\circ} \mathrm{F}\right)$ & $\left({ }^{\circ} \mathrm{C} /{ }^{\circ} \mathrm{F}\right)$ & $\left({ }^{\circ} \mathrm{C} /{ }^{\circ} \mathrm{F}\right)$ \\
1 & $88 / 190$ & $59 / 138$ & & \\
2 & $89 / 192$ & $69 / 156$ & $29 / 84$ & $25 / 77$ \\
3 & $76 / 169$ & $52 / 126$ & $49 / 102$ & $27 / 81$ \\
4 & $88 / 190$ & $76 / 169$ & $45 / 113$ & $34 / 93$ \\
5 & $85 / 184$ & $69 / 156$ & $13 / 55$ & $30 / 86$ \\
\hline
\end{tabular}

$\mathrm{n} \cdot \mathrm{r} .=$ not recorded 
The flue gas temperatures were somewhat lower in the masonry chimney due to the high mass and larger s1ze of the masonry chimney. A reduced draft in the larger masonry chimney kept firing rates low and made control of the flue gas temperature difficult and response slugg1sh. The high mass of the chimney led to slow response to changes in the air inlet. However, once operating temperatures were reached in the masonry chimney, steady temperatures were easily malntalned with little varlation in the flue gas temperature.

Enclosure temperatures rose 11ttle above amblent temperatures during the bulldup tests. Maximum temperature rises above amblent on the enclosures were $+3^{\circ} \mathrm{C}\left(5^{\circ} \mathrm{F}\right),+5^{\circ} \mathrm{C}\left(9^{\circ} \mathrm{F}\right),+12^{\circ} \mathrm{C}\left(22^{\circ} \mathrm{F}\right)$, and $+10^{\circ} \mathrm{C}\left(18^{\circ} \mathrm{F}\right)$ for chimneys 1 through 4, respectively. Since chimney 5 was installed outdoors, with no enclosure, no readings were recorded for this chimney.

Surprisingly, significant levels of creosote deposits were generated on the linings of all chimneys in very short perlods of time in a laboratory space whose air temperature averaged approximately $25^{\circ} \mathrm{C}\left(77^{\circ} \mathrm{F}\right)$ in the vicinity of the chimneys. The bulldup of deposits prior to tests 1 and 5 resulted from a total of only seven days continuous burning. After this short period, deposits up to $3 \mathrm{~mm}$ to $6 \mathrm{~mm}(1 / 8 \mathrm{in}$ to $1 / 4 \mathrm{ln})$ were evident in the chimneys. During the longer tests, connector plpe elbows became clogged with deposits after about six weeks. The heav1est bulldup was noted for the test of chimney 5. Since this chimney was allowed to bulld deposits over a longer perlod of t1me and was exposed to amblent temperatures much lower than the other chimneys, this result was expected.

Since the chimneys were not disassembled and weighed during the tests, no quantitative data are avallable on the relative amounts of creosote produced. Significant levels of creosote deposits were generated in the five different chimney designs, with both hard/seasoned and soft/green woods. Th1s 18 consistent with other studies. No discernable difference was noted in the level of bulldup between the two appliances used in the bulldup tests. Both appliances produced thicknesses of deposit sufficlent for severe chimney fires. 


\section{BURNOUT TESTS}

\subsection{Gas Temperatures}

The highest flue gas temperatures were usually noted in the section of the chimney connector closest to the appliance during the burnout tests. Peak temperatures for all chimneys ranged from a low of $908^{\circ} \mathrm{C}\left(1666^{\circ} \mathrm{F}\right)$ to a high of more than $1370^{\circ} \mathrm{C}\left(2500^{\circ} \mathrm{F}\right)$.

Peak Flue Gas Temperatures

Chimney

Peak Temperature $\left({ }^{\circ} \mathrm{C} /{ }^{\circ} \mathrm{F}\right)$

$\begin{array}{rrrrrrrrr}1 & (1) & 1008 / 1846 & (2) & 988 / 1810 & (3) & 1109 / 2028 & (4) & 996 / 1825 \\ 2 & (5) & 958 / 1756 & (6) & 965 / 1769 & (7) & 1050 / 1922 & (8) & 1030 / 1886 \\ 3 & (9) & 1095 / 2003 & & & & & & \\ 4 & (10) & 908 / 1666 & (11) & 1022 / 1872 & & & & \\ 5 & (12) & >1370 />2500 & & & & & & \end{array}$

Note: Numbers in parentheses are test numbers of the burnout tests

The average peak flue gas temperatures in the four chimneys tested in a conditioned laboratory were $1025^{\circ} \mathrm{C}\left(1877^{\circ} \mathrm{F}\right), 1044^{\circ} \mathrm{C}\left(1911^{\circ} \mathrm{F}\right), 1095^{\circ} \mathrm{C}\left(2003^{\circ} \mathrm{F}\right)$, and $965^{\circ} \mathrm{C}\left(1769^{\circ} \mathrm{F}\right)$ for chimney $1,2,3$, and 4 , respectively. The difference between the lowest average flue gas temperature (chimney 4 ) and the highest average flue gas temperature (chimney 3) was only 12 percent. Chimney 5, the solid-packed chimney tested outdoors in a colder environment was markedly different, however. Peak flue gas temperature during this test exceeded $1370^{\circ} \mathrm{C}\left(2500^{\circ} \mathrm{F}\right), 275^{\circ} \mathrm{C}\left(495^{\circ} \mathrm{F}\right)$ higher than the highest temperature recorded during the tests in a conditioned laboratory and $358^{\circ} \mathrm{C}\left(645^{\circ} \mathrm{F}\right)$ higher than the average peak temperature noted during the eleven indoor tests.

At the base of the chimney, beyond the chimney connector, temperatures were generally lower. Temperature measurement was made approximately $0.25 \mathrm{~m}$ (10 in) from the base of the chimney at a point $2.1 \mathrm{~m}$ (82 in) from the appliance outlet for the factory-built chimneys tested in a conditioned laboratory space (chimneys 1 to 4 ). Since the masonry chimney was connected to the appliance by a shorter $(0.9 \mathrm{~m} / 3 \mathrm{ft})$ section of chimney connector, temperature 
measurement was made at a point $1.2 \mathrm{~m}$ ( $4 \mathrm{ft}$ ) from the appliance outlet. Consequently, a higher flue gas temperature at the base of the chimney was recorded during the burnout test of the masonry chimney at $1095^{\circ} \mathrm{C}\left(2003^{\circ} \mathrm{F}\right)$ than for the other indoor chimneys. At a point $2.1 \mathrm{~m}(6.8 \mathrm{ft})$ from the appliance outlet, flue gas temperature in the masonry chimney was $918^{\circ} \mathrm{C}\left(1684^{\circ} \mathrm{F}\right)$, within the range of temperatures noted for chimneys 1, 2, and 4. For the other tests, the average maximum flue gas temperature at the base of the chimney was $883^{\circ} \mathrm{C}\left(1621^{\circ} \mathrm{F}\right)$ with a coefficient of variation of \pm 9 percent. As before, temperatures recorded during the burnout test of chimney 5 were considerably higher than those noted for the other chimneys. Individual maximums taken from figures 20 through 31 or tables 10 to 21 were:

Flue Gas Temperatures at the Base of the Chimneys

\begin{tabular}{|c|c|c|c|c|c|c|c|c|}
\hline Chimney & & & & ak Temper & re $(c$ & $\left.\mathrm{C} /{ }^{\circ} \mathrm{F}\right)$ & & \\
\hline 1 & (1) & $870 / 1598$ & (2) & $711 / 1311$ & (3) & $933 / 1711$ & (4) & $931 / 1707$ \\
\hline 2 & (5) & $902 / 1655$ & (6) & $954 / 1749$ & $(7)$ & $810 / 1490$ & (8) & $889 / 1632$ \\
\hline 3 & (9) & $1095 / 2003$ & & & & & & \\
\hline 4 & $(10)$ & $851 / 1563$ & (11) & $974 / 1785$ & & & & \\
\hline 5 & (12) & $1370 / 2498$ & & & & & & \\
\hline
\end{tabular}

Note: Numbers in parentheses are test numbers of the burnout tests

Maximum flue gas temperatures within the chimney were not always recorded at the base of the chimney. Location of peak temperature inside the chimney varied from the base of the chimney in the majority of tests ( 4 to 10 and 12) to the top of the chimney during test 2. Maximum temperatures were always close to the temperature measured at the base of the chimney:

Maximum Flue Gas Temperatures Inside Chimney

Chimney Peak Temperature $\left({ }^{\circ} \mathrm{C} /{ }^{\circ} \mathrm{F}\right)$

\begin{tabular}{|c|c|c|c|c|c|c|c|c|}
\hline 1 & (1) & $948 / 1738$ & (2) & $754 / 1389$ & (3) & $934 / 1713$ & (4) & $931 / 1707$ \\
\hline 2 & (5) & $902 / 1655$ & (6) & $954 / 1749$ & (7) & $810 / 1490$ & (8) & $889 / 1632$ \\
\hline 3 & (9) & $1095 / 2003$ & & & & & & \\
\hline 4 & (10) & $851 / 1563$ & (11) & $984 / 1803$ & & & & \\
\hline 5 & (12) & $1370 / 2498$ & & & & & & \\
\hline
\end{tabular}

Note: Numbers in parentheses are test numbers of the burnout tests 
The average maximum flue gas temperature inside the chimney for the factorybuilt chimneys tested indoors (chimneys 1,2 , and 4 ) was $896^{\circ} \mathrm{C}\left(1644^{\circ} \mathrm{F}\right)$ with a coefficient of variation of \pm 8 percent. If chimney 5 is included in the average, this temperature rises to $939^{\circ} \mathrm{C}\left(1745^{\circ} \mathrm{F}\right) \pm 17$ percent

Temperature variation from the base of the chimney to the top of the chimney (figures $32-43)$ was usually $200^{\circ} \mathrm{C}\left(360^{\circ} \mathrm{F}\right)$ or less. The largest variation in flue gas temperature over the length of the chimney was recorded for the masonry chimney $\left(610\right.$ to $1095^{\circ} \mathrm{C} / 1130$ to $\left.2003^{\circ} \mathrm{F}\right)$, the smallest in the solidpacked factory-built chimneys -838 to $889^{\circ} \mathrm{C}\left(1540\right.$ to $\left.1632^{\circ} \mathrm{F}\right)$ during test 8 and 902 to $984^{\circ} \mathrm{C}\left(1656\right.$ to $\left.1803^{\circ} \mathrm{F}\right)$ during test $11-$ a range of only $51^{\circ} \mathrm{C}\left(92^{\circ} \mathrm{F}\right)$ and $82^{\circ} \mathrm{C}\left(148^{\circ} \mathrm{F}\right)$, respectively:

Variation in Peak Flue Gas Temperatures Inside the Chimney Chimney Temperature Range $\left({ }^{\circ} \mathrm{C}\right)$

\begin{tabular}{lllllllll}
\hline 1 & $(1)$ & $767-948$ & $(2)$ & $642-754$ & $(3)$ & $724-934$ & (4) & $726-931$ \\
2 & $(5)$ & $756-902$ & $(6)$ & $775-954$ & $(7)$ & $665-810$ & (8) & $838-889$ \\
3 & $(9)$ & $610-1095$ & & & & & & \\
4 & $(10)$ & $633-851$ & $(11)$ & $902-984$ & & & \\
5 & $(12)$ & $921-1370$ & & & & & \\
\hline
\end{tabular}

$1 \quad$ (1) 1413-1738

2 (5) $1393-1656$

$3 \quad$ (9) $1130-2003$

$4 \quad(10) \quad 1171-1564$

5
(2) $1188-1389$

(6) $\quad 1427-1749$

(3) $1335-1713$

(7) $\quad 1229-1490$

(4) 1339-1708

(11) $1656-1803$

Note: Numbers in parentheses are test numbers of the burnout tests

The high thermal mass of the masonry chimney, combined with slower moving flue gas due to the larger size of the masonry chimney flue allowed the gas to cool to lower temperatures. The large range noted for chimney 5 was due to the colder ambient temperature leading to faster heat loss from the flue gas 
to the chimney surfaces. The lower mass but effective insulation of the sol1d-packed factory-bullt chimneys led to less heat loss along the length of these chimneys than noted for the masonry chimney.

The duration of the chimney fires as evidenced by elevated chimney temperatures varied considerably from test to test, even with similar periods of creosote bulldup. The length of the chimney f1res, defined here as flue gas temperatures greater than $200^{\circ} \mathrm{C}\left(392^{\circ} \mathrm{F}\right)$, varled from 760 s to $5940 \mathrm{~s}$--more than $11 / 2$ hours:

Duration of Flue Gas Temperatures Above $200^{\circ} \mathrm{C}\left(392^{\circ} \mathrm{F}\right)$ During Chimney Fires Chimney Time ( 8 )

\begin{tabular}{rrrrrrrrr}
\hline 1 & $(1)$ & 2280 & $(2)$ & 5415 & $(3)$ & 760 & $(4)$ & 980 \\
2 & $(5)$ & 3210 & $(6)$ & 2625 & $(7)$ & 840 & $(8)$ & 1310 \\
3 & $(9)$ & 1040 & & & & & & \\
4 & $(10)$ & 940 & $(11)$ & 3390 & & & \\
5 & $(12)$ & 5940 & & & & & \\
\hline
\end{tabular}

Note: Numbers in parentheses are test numbers of the burnout tests

The duration of higher temperatures and of pak temperatures was considerably less, however. Flue gas temperatures were above $700^{\circ} \mathrm{C}\left(1292^{\circ} \mathrm{F}\right)$ for only 100 s to 2250 s during the burnout tests:

Duration of Flue Gas Temperatures Above $700^{\circ} \mathrm{C}\left(1292^{\circ} \mathrm{F}\right)$ During Chimey Fires Chimney Time (s)

\begin{tabular}{lrrrrrrrr}
\hline 1 & $(1)$ & 860 & $(2)$ & 100 & $(3)$ & 500 & $(4)$ & 310 \\
2 & $(5)$ & 690 & $(6)$ & 865 & $(7)$ & 250 & $(8)$ & 380 \\
3 & $(9)$ & 440 & & & & & & \\
4 & $(10)$ & 260 & $(11)$ & 1290 & & & \\
5 & $(12)$ & 2250 & & & & & \\
\hline
\end{tabular}

Note: Numbers in parentheses are test numbers of the burnout tests 
Flue gas temperatures at levels above $1000^{\circ} \mathrm{C}\left(1832^{\circ} \mathrm{F}\right)$ were rarer still. Temperatures of $1000^{\circ} \mathrm{C}\left(1832^{\circ} \mathrm{F}\right)$ were reached in only seven of the twelve burnout tests. The duration of time above $1000^{\circ} \mathrm{C}\left(1832^{\circ} \mathrm{F}\right)$ ranged from only $10 \mathrm{~s}$ in test 1 to $500 \mathrm{~s}$ in test 12 :

Duration of Flue Gas Temperatures Above $1000^{\circ} \mathrm{C}\left(1832^{\circ} \mathrm{F}\right)$ During Chimney Fires Chimney Time ( 8 )

$\begin{array}{rrrrrrrrr}1 & (1) & 10 & (2) & 0 & (3) & 370 & (4) & 0 \\ 2 & (5) & 0 & (6) & 0 & (7) & 90 & (8) & 50 \\ 3 & (9) & 190 & & & & & & \\ 4 & (10) & 0 & (11) & 50 & & & \\ 5 & (12) & 500 & & & & & \end{array}$

Notes: Numbers in parentheses are test numbers of the burnout tests

\subsection{Chimney Surface Temperatures}

Temperatures on the outside surface of the inside chimney wall (the flue liner) were, naturally, lower than the flue gas temperatures--averaging $186^{\circ} \mathrm{C}$ $\left(336^{\circ} \mathrm{F}\right)$ lower. As with the flue gas temperatures, the peak inner chimney surface temperature was not necessarily recorded at the base of the chimney. Peak temperatures for all chimneys ranged from a low of $265^{\circ} \mathrm{C}\left(509^{\circ} \mathrm{F}\right)$ in the masonry chimney to $1111^{\circ} \mathrm{C}\left(2031^{\circ} \mathrm{F}\right)$ in one of the solid-packed factory-built chimneys:

Peak Chimney Surface Temperatures

Chimney Peak Temperature $\left({ }^{\circ} \mathrm{C} /{ }^{\circ} \mathrm{F}\right)$

$\begin{array}{lrrrrrrrr}1 & (1) & 778 / 1432 & (2) & 653 / 1207 & (3) & 814 / 1497 & \text { (4) } & 906 / 1662 \\ 2 & (5) & 758 / 1396 & (6) & 867 / 1592 & (7) & - & \text { (8) } & 874 / 1605 \\ 3 & (9) & 265 / 509 & & & & & & \\ 4 & (10) & 715 / 1319 & (11) & 917 / 1682 & & & & \\ 5 & (12) & 1111 / 2031 & & & & & & \end{array}$

Note: Numbers in parentheses are test numbers of the burnout tests 
Few differences were noted comparing the peak inner chlmney surface temperatures of the three factory-bu1lt chimneys tested in a conditioned laboratory space (chimneys 1, 2, and 4). The average of peak temperatures for all tests of the three 1ndividual factory-bu1lt chimneys were $788^{\circ} \mathrm{C}\left(1450^{\circ} \mathrm{F}\right), 805^{\circ} \mathrm{C}$ $\left(1481^{\circ} \mathrm{F}\right)$, and $812^{\circ} \mathrm{C}\left(1494^{\circ} \mathrm{F}\right)--a$ range of only $24^{\circ} \mathrm{C}\left(43^{\circ} \mathrm{F}\right)$. Understandably, the temperature on the masonry chimney was lower. Since all inner chimney wall temperatures were measured on the outer surface of the wall, the 16 mm $(5 / 8 \mathrm{in})$ of fire clay flue lining provided more insulation to heat conduction than the thinner stalnless steel linings of the factory-bullt chimneys. Following the flue gas temperatures, Inner chimney wall temperatures for chimney 5 were considerably higher than those recorded for the other chimneys.

Varlation in the Inner chimney wall temperatures from the base of the chlmney to the top was larger in magnitude than the varlation in flue gas temperatures, averaging $234^{\circ} \mathrm{C}\left(422^{\circ} \mathrm{F}\right)$. Lowest temperatures were usually, although not always, noted at the top of the chimney. Since the upper sections of chimney in all tests was not enclosed, greater heat $10 s 8$ was possible high in the chimney:

Variation in Inner Chimney Wall Temperatures

Chimney Temperature Range $\left({ }^{\circ} \mathrm{C}\right)$

\begin{tabular}{|c|c|c|c|c|c|c|c|c|}
\hline 1 & (1) & $590-778$ & (2) & $488-653$ & (3) & $514-814$ & (4) & $640-906$ \\
\hline 2 & (5) & $448-758$ & (6) & $531-867$ & (7) & $465-721$ & (8) & $650-874$ \\
\hline 3 & (9) & $108-265$ & & & & & & \\
\hline 4 & $(10)$ & $413-715$ & (11) & $836-909$ & & & & \\
\hline 5 & (12) & $714-1111$ & & & & & & \\
\hline
\end{tabular}

Ch1mney

Temperature Range $\left({ }^{\circ} \mathrm{F}\right)$

\begin{tabular}{lllllllll}
\hline 1 & $(1)$ & $1094-1432$ & $(2)$ & $910-1207$ & $(3)$ & $957-1497$ & (4) & $1184-1663$ \\
2 & $(5)$ & $838-1396$ & $(6)$ & $988-1593$ & (7) & $869-1330$ & (8) & $1202-1605$ \\
3 & $(9)$ & $226-509$ & & & & & & \\
4 & $(10)$ & $775-1319$ & $(11)$ & $1537-1668$ & & & \\
5 & $(12)$ & $1317-1111$ & & & & & \\
\hline
\end{tabular}

Note: Numbers in parentheses are test numbers of the burnout tests 
Peak temperatures on the exterior surface of the chimneys ranged from $46^{\circ} \mathrm{C}\left(115^{\circ} \mathrm{F}\right)$ on the outside surface of the masonry chimney to $433^{\circ} \mathrm{C}\left(811^{\circ} \mathrm{F}\right)$ on the outside surface of the air-insulated factory-built chimney. Averages of peak temperatures for all tests of the individual chimneys were $376^{\circ} \mathrm{C}\left(709^{\circ} \mathrm{F}\right)$, $205^{\circ} \mathrm{C}\left(401^{\circ} \mathrm{F}\right), 46^{\circ} \mathrm{C}\left(115^{\circ} \mathrm{F}\right), 212^{\circ} \mathrm{C}\left(414^{\circ} \mathrm{F}\right)$, and $289^{\circ} \mathrm{C}\left(552^{\circ} \mathrm{F}\right)$ for chimney 1 , chimney 2, chimney 3 , chimney 4 , and chimney 5, respectively:

\section{Peak Outer Chimney Surface Temperature}

Chimney

$\begin{array}{lrr}1 & (1) & 420 / 788 \\ 2 & (5) & 222 / 431 \\ 3 & (9) & 46 / 114 \\ 4 & (10) & 137 / 278 \\ 5 & (12) & 289 / 552\end{array}$

Peak Temperature $\left({ }^{\circ} \mathrm{C} /{ }^{\circ} \mathrm{F}\right)$

(2) $325 / 617$

(3) $327 / 620$

(4) $433 / 811$

(6) $233 / 451$

(7) $200 / 392$

(8) $168 / 334$

(11) $288 / 550$

Note: Numbers in parentheses are test numbers of the burnout tests

Thus, while flue gas temperatures were very similar in the four chimney designs, the different designs varied in their ability to retain the heat of the flue gas within the chimney. The masonry chimney, by virtue of its high mass, barely reacted at all to the relatively short duration of the chimney fire $(940 \mathrm{~s})$. In contrast, the light weight of the air-insulated chimney allowed temperatures to rise considerably.

The length of time the outside chimney surface remained at elevated temperature levels varied considerably from test to test. In several tests, $200^{\circ} \mathrm{C}\left(392^{\circ} \mathrm{F}\right)$ was never reached while in other tests, temperatures on the outside of the chimney were in excess of $200^{\circ} \mathrm{C}\left(392^{\circ} \mathrm{F}\right)$ for more than $1300 \mathrm{~s}$ : 
Duration of Elevated Temperatures on Outside Chimney Wall

Chimey

Time (s)

\begin{tabular}{rrrrrrrrr}
\hline 1 & $(1)$ & 1390 & $(2)$ & 1475 & (3) & 640 & (4) & 800 \\
2 & $(5)$ & 790 & $(6)$ & 905 & $(7)$ & 5 & (8) & 0 \\
3 & $(9)$ & 0 & & & & & & \\
4 & $(10)$ & 0 & $(11)$ & 1860 & & & & \\
5 & $(12)$ & 1416 & & & & & \\
\hline
\end{tabular}

Notes: Numbers in parentheses are test numbers of the burnout tests

\subsection{Enclosure Temperatures}

Temperature levels on the surfaces of the combustible enclosure facing the chimneys also varied considerably from test to test. Maximum temperatures measured ranged from $39^{\circ} \mathrm{C}\left(102^{\circ} \mathrm{F}\right)$ to $234^{\circ} \mathrm{C}\left(453^{\circ} \mathrm{F}\right)$. Following the ranking of the chimneys by outside surface temperature, the lowest temperatures were noted for the masonry chlmney and the highest temperatures for the alrinsulated chimney. Average maximum temperatures for all enclosure thermocouples in each test were $133^{\circ} \mathrm{C}\left(271^{\circ} \mathrm{F}\right), 91^{\circ} \mathrm{C}\left(196^{\circ} \mathrm{F}\right), 37^{\circ} \mathrm{C}\left(99^{\circ} \mathrm{F}\right)$ and $91^{\circ} \mathrm{C}$ $\left(196^{\circ} \mathrm{F}\right)$ for chimney 1 , chimney 2 , chimney 3 , and chimney 4 , respectively. Since no enclosure was used for chimney 5 , no data are noted:

Peak Enclosure Surface Temperature

\begin{tabular}{cccccccr} 
ChImney & \multicolumn{8}{c}{ Peak Temperature $\left({ }^{\circ} \mathrm{C} /{ }^{\circ} \mathrm{F}\right)$} \\
\hline 1 & $(1)$ & $154 / 309$ & (2) $182 / 359$ & (3) $177 / 350$ & (4) & $234 / 453$ \\
2 & $(5)$ & $97 / 206$ & (6) $112 / 233$ & (7) $112 / 233$ & (8) & $95 / 203$ \\
3 & $(9)$ & $39 / 102$ & & & & & \\
4 & $(10)$ & $62 / 143$ & (11) $149 / 300$ & & & \\
5 & $(12)$ & - & & & & &
\end{tabular}

Note: Numbers in parentheses are test numbers of the burnout tests. No enclosure wall used for chimney 5 .

In all tests but one, peak temperatures on the enclosure surface were recorded at the topmost thermocouple location. During the test of the masonry chimney, the highest temperature was noted at the base of the enclosure. However, 
during this test, all the enclosure temperatures were within $3^{\circ} \mathrm{C}\left(5^{\circ} \mathrm{F}\right)$ of the peak temperature of $39^{\circ} \mathrm{C}\left(102^{\circ} \mathrm{F}\right)$ with a rise in temperature of only 10 to $13^{\circ} \mathrm{C}$ (18 to $23^{\circ} \mathrm{F}$ ) above room ambient air temperature.

Temperatures on combustible enclosure surfaces were elevated for considerable periods of time during most tests. Enclosure temperatures exceeded the criterion used for testing and listing of chimneys of $50^{\circ} \mathrm{C}\left(90^{\circ}\right)$ above room temperature for times as long as 56 minutes. In some tests, temperatures on enclosure surfaces were elevated for periods of time equal to or greater than the duration of the creosote fire in the chimney:

\section{Duration of Elevated Temperatures on Enclosure Surfaces $\left(50^{\circ} \mathrm{C} / 90^{\circ} \mathrm{F}\right.$ Rise Above Room Temperature)}

Chimney

Time (s)

\begin{tabular}{lrrrrrrrr}
\hline 1 & $(1)$ & 1350 & $(2)$ & 2150 & $(3)$ & 610 & (4) & 1660 \\
2 & $(5)$ & 750 & $(6)$ & 945 & $(7)$ & 145 & (8) & 1170 \\
3 & $(9)$ & 0 & & & & & & \\
4 & $(10)$ & 0 & $(11)$ & 3330 & & & \\
5 & $(12)$ & - & & & & & \\
\hline
\end{tabular}

Note: Numbers in parentheses are test numbers of the burnout tests. No enclosure was used for chimney 5 .

\subsection{Damage to Chimney Systems}

There was little visible damage to the chimneys after most of the chimney fires. After four chimney creosote burnouts of chimney 1 , degradation of the galvanized outer pipe was evidenced by a dulling of the coating on the upper sections of the chimney. While this would not affect chimney performance immediately, the loss of galvanization would lead to corrosion over longer periods of time. Flue linings were undamaged. After tests of chimneys 2 and 4 (two solid-packed factory-built chimneys) no damage was apparent on the interior or exterior of the chimneys. Flue linings were relatively clean, with no distortions visible. 
Damage to chimney 3 (a masonry chimney) and to chimney 5 (a solid-packed factory-bullt chimney) were more significant, however. Inspection of the masonry chimney after the creosote burnout test revealed cracks along the molding seams of the tile liners 6 to $12 \mathrm{~mm}(1 / 4$ to $1 / 2 \mathrm{in})$ in width along the entire length of the chimney. Numerous smaller cracks were evident throughout the liner sections upon subsequent disassembly of the chimney. After the test of chimney 5, damage was evident in all sections of the chimney. In the Tee section, where temperatures were the highest, holes were found over the entire surface of the inner wall. The holes ranged in size from small, barely noticeable penetrations to one approximately 50 by $80 \mathrm{~mm}$ ( 2 by $3 \mathrm{fn}$ ). Although most severe at the base of the chimney, buckling of the inner wall was apparent in all sections. Buckling in both the radial and longitudinal directions was found, resulting in separation at the ends of each section and exposing the insulation between the walls. Figures 60 to 63 1llustrate the damage to chimneys 3 and 5 .

\section{OVERFIRE TESTS}

Overfire tests--continuous firing at maximum rates for extended periods of time--were conducted to compare with temperature levels attained during the chimney fire burnout tests. Each chimney and appliance combination was fired continuously unt 11 maximum temperatures were attalned on all surfaces. All chimneys, except chimney 5, were tested prior to conducting creosote burnout tests. Chimney 5 was tested in a damaged condition to assess temperatures on exterior surfaces after damage had occurred.

\subsection{Maximum Temperatures}

Maximum temperatures recorded during the overfire tests were always noted at the base of the chimney or in the lower sections of the chimney. Temperatures at the base of the chimney ranged from 772 to $916^{\circ} \mathrm{C}$ ( 1422 to $1681^{\circ} \mathrm{F}$ ) in the flue gas, 358 to $849^{\circ} \mathrm{C}\left(676\right.$ to $\left.1560^{\circ} \mathrm{F}\right)$ on the inner wall of the chimney, 143 to $305^{\circ} \mathrm{C}\left(289\right.$ to $\left.581^{\circ} \mathrm{F}\right)$ on the outer wall of the chimney and 57 to $145^{\circ} \mathrm{C}$ $\left(135\right.$ to $293^{\circ} \mathrm{F}$ ) on the enclosure. Peak temperatures at any position within the chimney were simflar to those recorded at the base of the chimney: 


\section{At Base of Chimney}

\begin{tabular}{ccccc} 
Ch1mney & $\begin{array}{c}\text { Flue } \\
\text { Gas }\end{array}$ & $\begin{array}{c}\text { Inner } \\
\text { Wall }\end{array}$ & $\begin{array}{l}\text { Outer } \\
\text { Wall }\end{array}$ & Enclosure \\
\hline & \multicolumn{3}{c}{$\left({ }^{\circ} \mathrm{C} /{ }^{\circ} \mathrm{F}\right)$} \\
1 & $830 / 1526$ & $654 / 1209$ & $182 / 360$ & $57 / 135$ \\
2 & $939 / 1722$ & $673 / 1243$ & $199 / 390$ & $66 / 151$ \\
3 & $772 / 1422$ & $358 / 676$ & $143 / 289$ & $100 / 212$ \\
4 & $916 / 1681$ & $849 / 1560$ & $305 / 581$ & $145 / 293$ \\
5 & $692 / 1277$ & n.r. & $160 / 320$ & -
\end{tabular}

Overal1

\begin{tabular}{clllc} 
Chimney & $\begin{array}{l}\text { Flue } \\
\text { Gas }\end{array}$ & $\begin{array}{l}\text { Inner } \\
\text { Wall }\end{array}$ & $\begin{array}{l}\text { Outer } \\
\text { Wall }\end{array}$ & Enclosure \\
\hline & & \multicolumn{3}{c}{$\left({ }^{\circ} \mathrm{C} /{ }^{\circ} \mathrm{F}\right)$} \\
1 & $836 / 1537$ & $668 / 1234$ & $270 / 518$ & $118 / 244$ \\
2 & $939 / 1722$ & $831 / 1528$ & $206 / 403$ & $108 / 226$ \\
3 & $772 / 1422$ & $358 / 676$ & $156 / 313$ & $116 / 241$ \\
4 & $916 / 1681$ & $849 / 1560$ & $334 / 633$ & $171 / 340$ \\
5 & $718 / 1324$ & $635 / 1175$ & $160 / 320$ & - \\
\hline
\end{tabular}

n.r. = not recorded. No enclosure was used for chimney 5.

The average of the peak flue gas temperatures during the overfire tests of the factory-built chimneys was $830^{\circ} \mathrm{C}\left(1526^{\circ} \mathrm{F}\right)$ with a coefficient of variation of \pm 12 percent--somewhat lower than the average of the peak flue gas temperatures during the burnout tests. During most tests of the factory-built chimneys, inside chimney surface temperatures were, in contrast, considerably lower during the overfire tests than during the burnout tests. In the overfire test of the masonry chimney, both flue gas temperatures and chimney surface temperatures were higher than those recorded during the burnout tests.

During a creosote burnout, combustion takes place on or near the chimney walls. Thus, measurement of the flue gas at the midpoint of the chimney may not indicate maximum temperatures in the chimney. Temperatures are likely to be considerably higher nearer to the walls of the chimney. Thus, a measurement of simply a single flue gas temperature may not be sufficient to fully understand the effects of a chimney fire. In the masonry chimney, the high thermal mass of the chimney and the relatively short duration of the chimney fire allowed the chimney to absorb the heat from the chimney fire. 


\subsection{Duration of Elevated Temperatures}

Perhaps more enlightening than peak temperatures is the duration of elevated temperatures during the overfire tests. Flue gas temperatures were above $200^{\circ} \mathrm{C}\left(392^{\circ} \mathrm{F}\right)$ for 87 to 98 percent of the overfire tests of the factorybullt chimneys but only 34 percent of the duration of the masonry chimney overfire test. Gas temperatures were above $700^{\circ} \mathrm{C}\left(1292^{\circ} \mathrm{F}\right)$ for 12 to 39 percent of the tests of the factory-bullt chimneys but only 0.4 percent of the masonry chimney test. Enclosure surface temperatures, however, do not reveal the same split. Temperatures on the surfaces surrounding the chimneys were more than $50^{\circ} \mathrm{C}\left(90^{\circ} \mathrm{F}\right)$ above room temperature for 11 to 89 percent of the time during the overfire tests of the factory-bullt chimneys and 50 percent of the time during the masonry chimney overfire test.

Duration of Elevated Temperatures During Overfire Tests

\begin{tabular}{ccccc} 
Chimney & $\begin{array}{c}\text { Flue Gas } \\
>\end{array} 200^{\circ} \mathrm{C}$ & $\begin{array}{c}\text { Flue Gas } \\
>700^{\circ} \mathrm{C}\end{array}$ & $\begin{array}{c}\text { Outer Surface } \\
>200^{\circ} \mathrm{C}\end{array}$ & $\begin{array}{c}\text { Enclosure } \\
>50^{\circ} \mathrm{C} \text { rise }\end{array}$ \\
\hline & $(\%)$ & $(\%)$ & $(\%)$ & $(\%)$ \\
1 & 95 & 12 & & 25 \\
3 & 95 & 15 & n.r. & 11 \\
4 & 34 & 0.4 & n.r. & 50 \\
5 & 87 & 39 & 75 & 89 \\
\hline
\end{tabular}

n.r. = not reached. No enclosure was used for chimney 5 .

\section{CONCLUSIONS}

A total of 22 tests were conducted on flve chimneys of differing designs. The tests were run to 1nvestigate the effects of creosote fires on the chimneys and on surrounding combustibles. Three serles of tests were conducted:

- F1ve "bulldup tests" where measurements of chimney temperatures and surrounding surface temperatures were recorded for a full day during the long perlods of low-level burning to deposit creosote on the chlmney surfaces, 
- Twelve "burnout tests" where the deposits were ignited and allowed to burn freely until maximum temperatures were reached in the chimney and on surrounding surfaces, and

- Five "overfire tests" where the appliances were fired at high rates for extended periods of time until steady-state conditions were obtained.

Significant levels of buildup were noted in all chimneys using both seasoned hardwoods and green softwoods. While buildup rates and quantities of deposits were not measured quantitatively, little difference was noted in the amount of buildup thickness during the various tests. Flue gas temperature, chimney surface temperature, and duration of the buildup period appear to be more important to creosote buildup than the type of chimney used or wood burned.

Flue gas temperatures in excess of $1370^{\circ} \mathrm{C}\left(2498^{\circ} \mathrm{F}\right)$ were obtained for short periods of time during the chimney fire "burnout tests." Maximum chimney surface temperatures over $1100^{\circ} \mathrm{C}\left(2000^{\circ} \mathrm{F}\right)$ were recorded. The fire clay flue lining of the masonry chimney was severely cracked during the chimney fire "burnout test." However, because of the chimney's high mass, temperatures on the outside brick surface never approached an unacceptable level of $50^{\circ} \mathrm{C}\left(90^{\circ} \mathrm{F}\right)$ above ambient temperature as defined in the various testing standards $[17,27]$. Severe damage was noted after one chimney fire in one of the factory-built chimney tests. Holes were found in the inner wall of the chimney near the base and buckling of the metal lining was noted in all sections.

Temperatures on surrounding combustible surfaces reached as high as $234^{\circ} \mathrm{C}$ $\left(453^{\circ} \mathrm{F}\right)$ during the "burnout tests," far in excess of acceptable limits and nearing the ignition temperature commonly reported for wood. The highest enclosure temperatures were noted during tests of the air-insulated chimney, the lowest during tests of the masonry chimney. Enclosure temperatures exceeded the criterion used for testing and listing of chimneys of $50^{\circ} \mathrm{C}\left(90^{\circ} \mathrm{F}\right)$ above room temperature for times as long as 56 minutes. In some tests, temperatures on surrounding combustibles were elevated above acceptable limits for periods of time equal to or greater than the duration of the creosote fire in the chimney. 
"Overfire tests"--continuous firing at maximum rates for extended periods of time--were nearly as severe as the "burnout tests." Flue gas temperatures of 772 to $939^{\circ} \mathrm{C}\left(1422\right.$ to $\left.1722^{\circ} \mathrm{C}\right)$ were recorded. Enclosure surface temperatures as high as $171^{\circ} \mathrm{C}\left(340^{\circ} \mathrm{F}\right)$ were obtained. In addition, flue gas temperatures during the "overfire tests" were above $200^{\circ} \mathrm{C}\left(392^{\circ} \mathrm{F}\right)$ for 87 to 98 percent of the duration of the tests and above $538^{\circ} \mathrm{C}\left(1000^{\circ} \mathrm{F}\right)$ for 3 to 58 percent of the duration of the tests.

Some specific conclusions can be made based upon the results of these tests:

- Current test procedures for factory-built chimneys include provisions for testing to simulate chimney fires by a 10 minute test at a flue gas temperature of $927^{\circ} \mathrm{C}\left(1700^{\circ} \mathrm{F}\right)$ or three 10 minute tests at $1149^{\circ} \mathrm{C}$ $\left(2100^{\circ} \mathrm{F}\right)$. Based upon the tests reported herein, the duration of a chimney fire simulation should be longer--a period of 20 minutes or longer would be more appropriate. Little damage to chimney systems were noted at temperatures of 927 to $1149^{\circ} \mathrm{C}\left(1700\right.$ to $\left.2100^{\circ} \mathrm{F}\right)$. Significantly higher temperatures were recorded during a test of one chimney in cold climatic conditions, with notable damage to the chimney. However, the results presented in this report are based upon a limited number of tests. Other chimney systems, and certainly colder climatic conditions could lead to more severe results. More tests would be necessary to provide information on reproducibility and temperature levels for other appliances and chimeys.

- Since burning occurs on and near the chimney walls, measurement of flue gas temperature near the walls or of chimney wall surface temperature is more appropriate than measurement of flue gas temperature at a single point on the center of the flue.

- Highest flue gas temperatures were usually noted at or near the appliance flue outlet. If damage were to occur due to the heat generated by a chimney fire, it would most likely occur near the appliance flue outlet. Thus, placing of factory-built chimney sections directly at the appliance flue outlet may be hazardous. Since flue gas tempera- 
tures are the highest at this location and since the factory-bullt chimney sections are insulated to hold the heat in, excessive temperatures may result. A length of single wall chimney connector (with proper clearances to nearby combustibles) would reduce the problem.

- Particularly noticeable on the surrounding combustible surfaces were the high temperatures resulting from the long duration of the overfire tests. Temperature rises in excess of recommended limits were recorded for long periods of time for all four chimneys. In some cases, temperature rises of more than $150^{\circ} \mathrm{C}\left(270^{\circ} \mathrm{F}\right)$ were noted.

\section{REFERENCES}

[1] Peacock, R. D., A Review of Fire Incldents, Model Bullding Codes, and Standards Related to Wood-Burning Appliances, Nat. Bur. Stand. (U.S.), NBSIR 79-1731 (Apr11 1979).

[2] Peacock, R. D., A Review of Fire Incidents Related to Wood-Burning Appliances, Wood Energy Institute, Proceedings of Wood Heating Seminar IV, Portland, Oregon, March 21-24, 1979, 43-46.

[3] Shelton, J. W., Analysis of Fire Reports on File in the Massachusetts State Fire Marshal's office Relating to Wood and Coal Heating Equipment, contract to the National Bureau of Standards (U.S.), NBS-GCR-78-149 (November 1978).

[4] Kale, D., Fires in Woodburning Appliances, U.S. Consumer Product Safety Commission (December 1982).

[5] Harwood, B. and Kale, D., Fires Involving Fireplaces, Chimneys and Related Appliances, U.S. Consumer Product Safety Commission (September 1981).

[6] Jones, J. C., 1980 Multiple-Death F1res in the United States, F1re Journa1, Vo1. 75, No. 5, 74-79, 106-109 (September 1981).

[7] Harwood, B. and Kluge, P., Hazards Associated with the Use of Wood or Coal-Burning Stoves or Free-Standing Fireplaces, U.S. Consumer Product Safety Commission (February 1980).

[8] Peacock, R. D., Rulz, E., and Torreo-Perena, R., Fire Safety of WoodBurning Appliances, Part 1: State of the Art Review and Fire Tests, Volumes I and II, Nat. Bur. Stand. (U.S.), NBSIR 80-2140 (November 1980).

[9] Shelton, J. W., Wood Heat Safety, (Garden Way Publishing, Charlotte, Vermont, September 1979). 
[10] The BOCA Basic Building Code/1978, Model Building Regulations for the Protection of Public Health, Safety and Welfare, Seventh Edition, Building officials and Code Administrators International, Homeward, Illinois (1978).

[11] The BOCA Basic Mechanical Code/1978, Model Mechanical Regulations for the Protection of Public Health, Safety and Welfare, Third Edition, Building officials and Code Adninistrators International, Homeward, Illinois (1978).

[12] The National Building Code, 1976 Edition, American Insurance Association, New York, New York (1976).

[13] National Fire Codes, Vol. 9, Standard for Chimneys, Fireplaces, and Vents, NFPA 211-1977, National Fire Protection Association, Boston, Massachusetts (1978)。

[14] Standard Bullding Code, 1976 Edition, Southern Building Code Congress, Internationa1, Inc., Birmingham, Alabama (1976).

[15] Amendments to the Standard Bullding Code, 1977 and 1978 Revisions to the 1976 Edition, Southern Building Code Congress, International, Inc., Birmingham, Alabama (1978).

[16] Uniform Bullding Code, 1976 Edition, International Conference of Bulding Officials (1976).

[17] 1977 Supplement to the Uniform Building Code, U.B.C. Standards, Uniform Housing Code, Uniform Code for the Abatement of Dangerous Buildings and the Uniform Fire Code, International Conference of Bullding officials (1977).

[18] Standard for Chimneys, Factory-Built, Residential Type, and Building Heating Appliance, UL103, Sixth Edition, Underwriters Laboratories, Inc. (February 1983).

[19] Voigt, G. Q., Fire Hazard of Domestic Heating Installations, Nat. Bur. Stand. (U.S.), NBS Research Paper RP596 (September 1933).

[20] Neale, J. A., Clearances and Insulation of Heating Appliances, Underwriters Laboratories, Inc., UL Bulletin of Research 非7 (February 1943).

[21] Lawson, D. I., Fox, L. L., and Webster, C. T., The Heating of Panels by Flue Pipes, Fire Research Special Report No. 1, Fire Protection Association, London, England (1952).

[22] Lawson, D. I. and Simms, D. L., The Ignition of Wood by Radiation, British Journal of Applied Physics, Vol. 3, 288-292 (September 1952).

[23] Shoub, H., Survey of Literature on the Safety of Residential Chimneys and Fireplaces, Nat. Bur. Stand. (U.S.), NBS Misc. Pub. 252 (December 1963). 
[24] Prefabricated Metal Chimneys, National Bureau of Standards, Fire Research Section, unpublished reports to Federal Public Housing Authority (1941-1945).

[25] Temperatures Developed in Chimneys for Low Cost Houses, Nat. Bur. Stand. (U.S.), Tech. News Bul1., 328 (August 1944).

[26] Fox, L. L. and Whittaker, D., Some Measurements of Temperatures of Metal Flues of Domestic Heating Appliances, Journal of the Institution of Heating and Ventilation Engineers, Vol. 23, 183-192 (August 1955).

[27] Standard for Chimneys, Factory-Built Residential Type and Building Appliance, UL 103, Fourth Edition, Underwriters Laboratories, Inc. (March 1971).

[28] Standard for Room Heaters, Solid Fuel Type, First Edition, UL 1482, Underwriters Laboratories, Inc. (August 1979).

[29] McKinnon, G. P. and Tower, K., Eds., Fire Protection Handbook, 14th Edition, National Fire Protection Association, Boston, Massachusetts, pages 3-2 to 3-7 (1976).

[30] Mitchel1, N. D., New Light on Self-Ignition, NFPA Quarterly, Vol. 45, No. 2, 165-172 (October 1951).

[31] MacLean, J. D., Effect of Heat on Properties and Serviceability of Wood: Experiments on Thin Wood Specimens, Forest Products Laboratory Report No. Rl471, Madison, Wisconsin (1945).

[32] MacLean, J. D., Rate of Disintegration of Wood Under Different Heating Conditions, American Wood-Preservers Association (1951).

[33] McGuire, J. H., Limiting Safe Surface Temperature of Combustible Materials, Fire Technology, Vol. 5, No. 3 (August 1969).

[34] Ignition and Charring Temperatures of Wood, Forest Products Laboratory Report No. 1464, Madison, Wisconsin (January 1958).

[35] Matson, A. F., Dufori, R. E., and Breen, J. F., Performance of Type B Gas Vents for Gas-Fired Appliances, Part II, Survey of Available Information on Ignition of Wood Exposed to Moderately Elevated Temperatures, Underwriters Laboratories, Inc., Bulletin of Research, No. 51, Northbrook, I11inois (May 1959).

[36] Flink, C. R., Factory-Built Chimneys, Wood Energy Institute, Proceedings of Wood Heating Seminar IV, Portland, Oregon, March 21-24, 1979, 339-342.

[37] Stone, R. L., Solving the Creosote Problem, Fire Journal, Vo1. 74, No. 1, 43-49, 78 (January 1980).

[38] Maxwell, T. T., Dyer, D. F., Maples, G., and Burch, T., An Investigation of Creosoting and Fireplace Inserts, contract to the National Bureau of Standards (U.S.), NBS-GCR-81-365 (December 1981). 
[39] Maxwe11, T. T., Maples, G., Pruitt, T. M., and Dyer, D. F., Design Handbook for Residential Wood-Burning Equ1pment, Department of Mechanical Englneering, Auburn Un1versity (July 1979).

[40] Dyer, D., Maxwell, T. T., and Nunnelly, R. M., Residential Consumer's Handbook for Wood-Fired Appliances, Department of Mechanical

Engineering, Auburn University (November 1981). 
Table 1

Instrumentation for Chimneys 1, 2, and 4

Me asurement

Locations

Amblent Atr Temperature

Flue Gas in Connector

$0.5,1.4 \mathrm{~m} \mathrm{level,} \mathrm{measured} \mathrm{from} \mathrm{appllance} \mathrm{outlet.}$

Flue Gas in Chimney

$2.1,2.3,2.9,3.1,3.6,3.9,4.4,4.6 \mathrm{~m}$ leve 1 , measured from appliance outlet.

Inner ChImney Wall

$2.1,2.3,2.9,3.1,3.6,3.9,4.4,4.6 \mathrm{~m}$ leve1, measured from appliance outlet.

Outer Chimney Wall

$2.1,2.3,2.9,3.1,3.6,3.9,4.4,4.6 \mathrm{~m}$ leve1, measured from appliance outlet.

Enclosure Surface

$2.1,2.3,2.9,3.1,3.6,3.9 \mathrm{~m}$ leve1, measured from appliance outlet. 
Table 2

Instrumentation for Chimney 5

Measurement

Locations

Amblent Alr Temperature

Flue Gas in Connector

$0.5,1.2 \mathrm{~m}$ level, measured from appllance outlet.

Flue Gas in Chimney

$1.5,2.0,2.2,2.7,3.0,3.5,3.8,4.3,4.5,5.0$, $5.3,5.8,6.1,6.6,6.8 \mathrm{~m}$ level, measured from appliance outlet.

Inner Chimney Wall

$2.0,2.2,2.7,3.0,3.5,3.8,4.3,4.5,5.0,5.3$, $5.8,6.1,6.6,6.8 \mathrm{~m}$ level, measured from appliance outlet.

Outer ChImney Wall

$2.0,2.2,2.7,3.0,3.5,3.8,4.3,4.5,5.0,5.3$, $5.8,6.1,6.6,6.8 \mathrm{~m}$ level, measured from appliance outlet. 
Table 3

Instrumentation for Chimney 3

Measurement

Locations

Ambient Air Temperature

Flue Gas in Chimney

$0.6,1.2,1.8,2.4,3.1,3.5 \mathrm{~m}$ level, measured from appliance outlet.

Inner Chimeny Wall

$0.3,0.6,0.9,1.2,1.5,1.8,2.1,2.4,2.7,3.1$, $3.4,3.5 \mathrm{~m}$ level, measured from appliance outlet.

Outer Chimney Wall

$0.3,0.6,0.9,1.2,1.5,1.8,2.1,2.4,2.7,3.1$, $3.4,3.5 \mathrm{~m} \mathrm{level,} \mathrm{measured} \mathrm{from} \mathrm{appliance} \mathrm{outlet.}$

Enclosure Surface

$0.3,0.6,0.9,1.2,1.5,1.8,2.1,2.4,2.7 \mathrm{~m}$ level, measured from appliance outlet.

Stove Surface

Door, Center Left Side, Center Right Side, Top Center, Back Center, Front Center. 


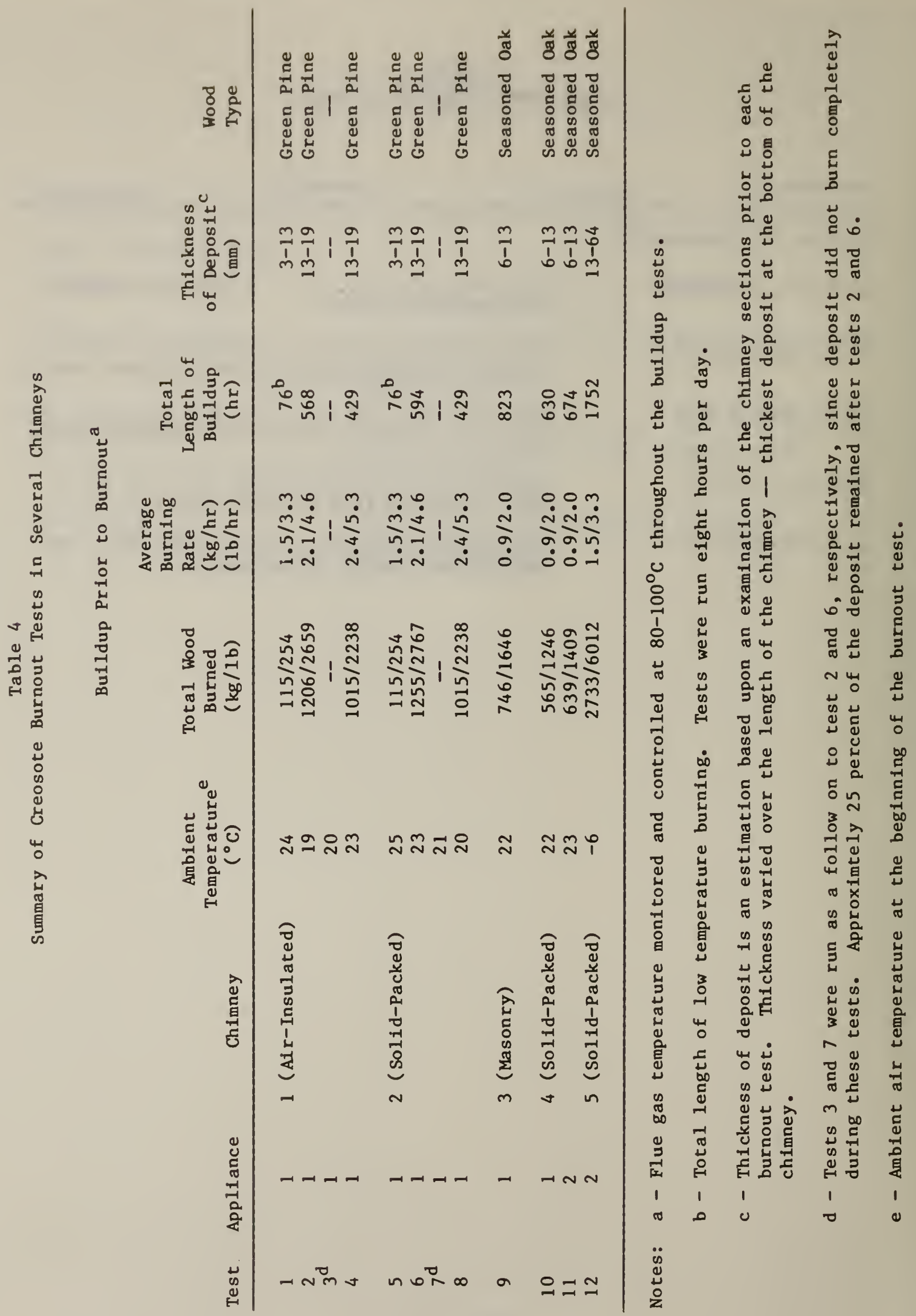




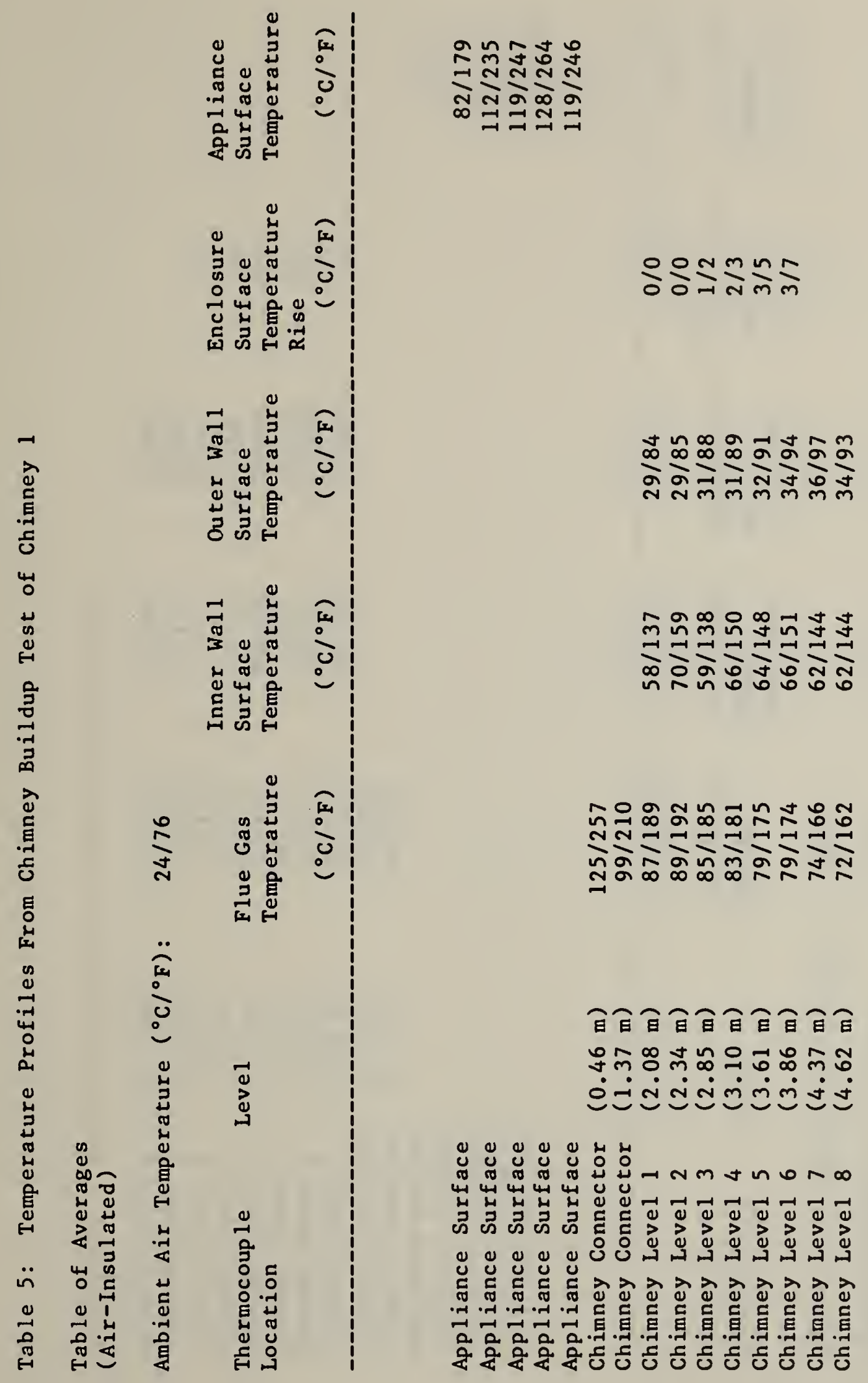


N

离

㟧

岁

号

离

点

(1)

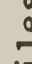

㟧

a

政

2

然

㬅

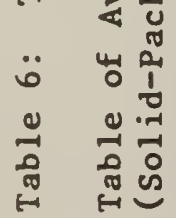

$\infty$

$\stackrel{0}{\infty}=$

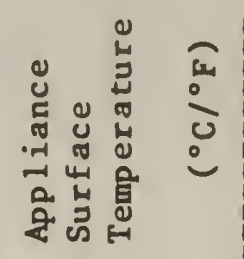

范

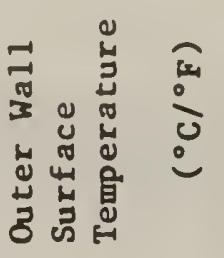

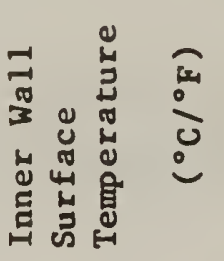

స

崩

$\frac{4}{4}$

4

范
ำกับกับ

웜ำ

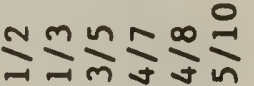

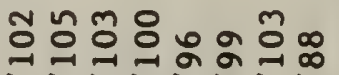

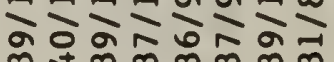

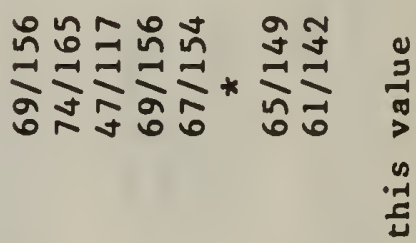

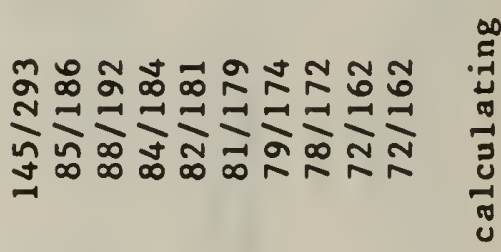

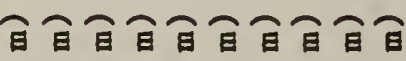
ษก๊

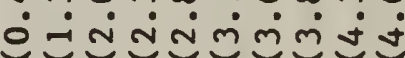

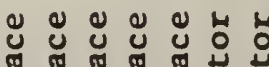

$4 n m+n 0 N \infty$

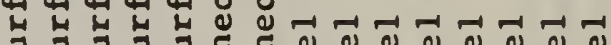
ผ ผ

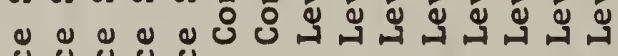
U U U U

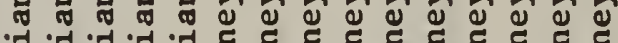

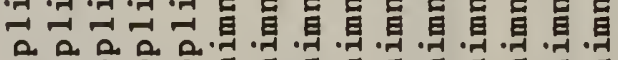

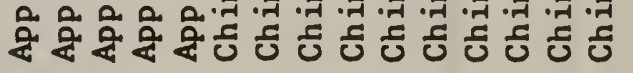

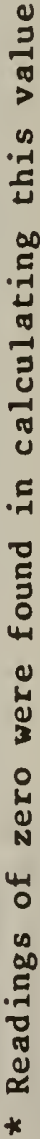



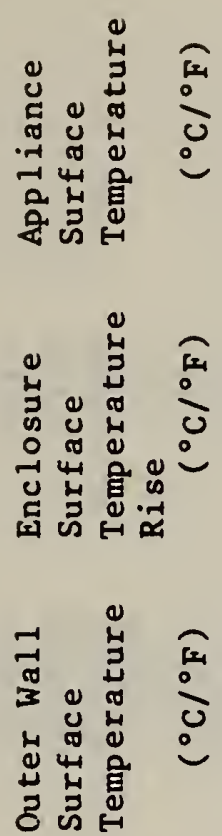

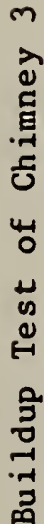

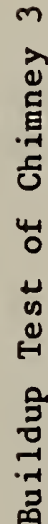

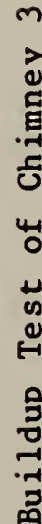

.

ํํำ

a

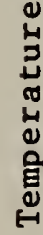

4.

$\ddot{\sim}$

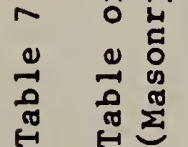

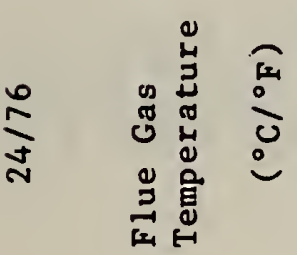

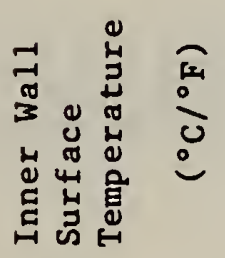

$n m m+\infty N$

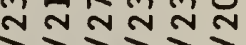

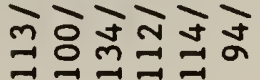

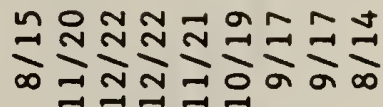

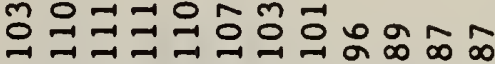

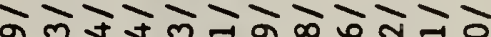

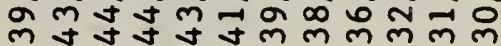

ํํำ

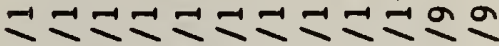

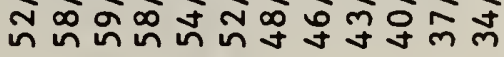

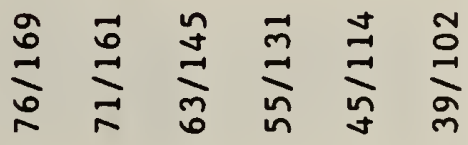

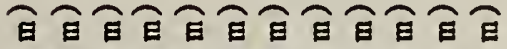

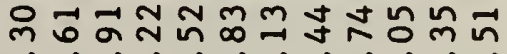

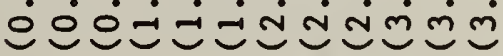

尫 出出出出出出子ન

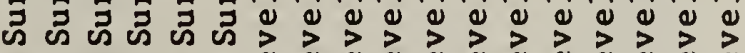
๑

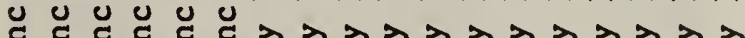

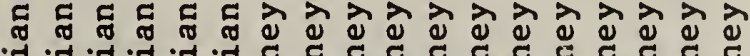

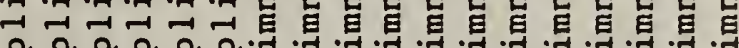

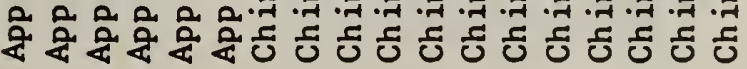



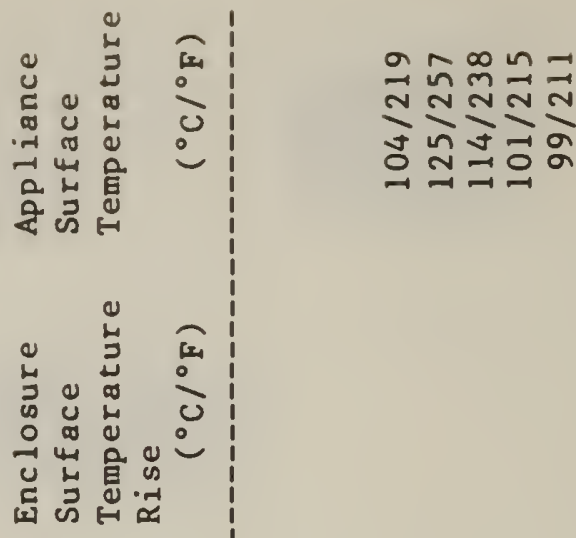

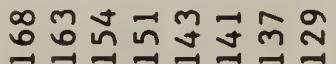

ㄱำ

ำ

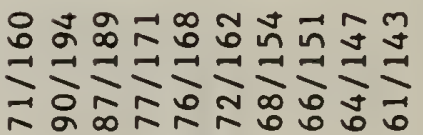

是

(1)

$\stackrel{2}{2}$

$\infty \sim$

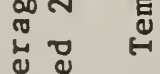

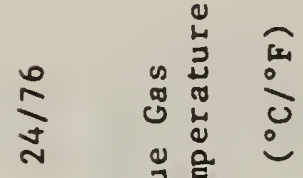
号昌

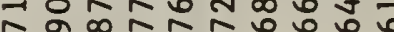

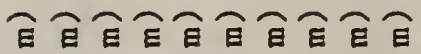

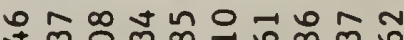
○

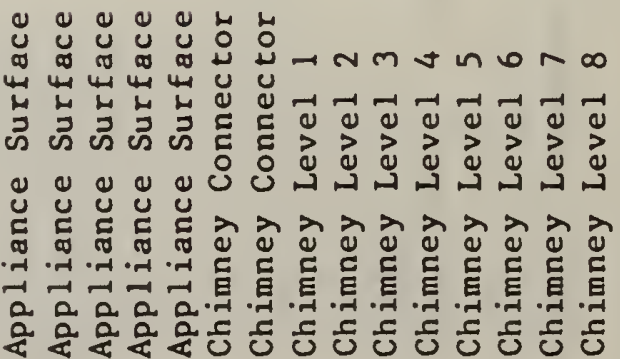




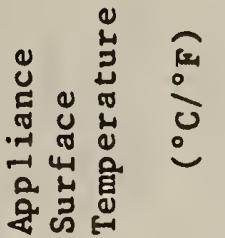

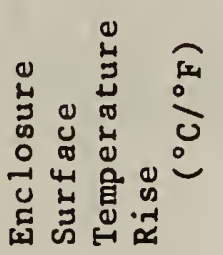

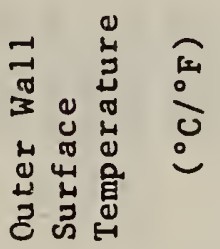

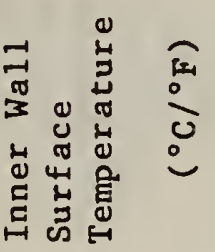

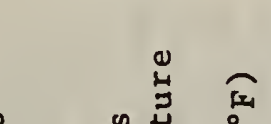

$\begin{array}{llll}\infty & 0 & \text { E } & 0 \\ N & 0 & 0 & 0 \\ 1 & 0 & 0 & 0\end{array}$ त्-

E

in

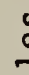

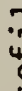

㟧

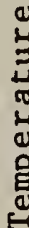

s.

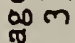

:

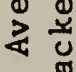

a

营

竞

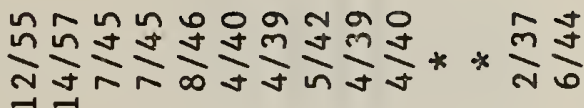

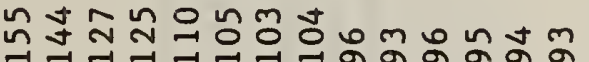

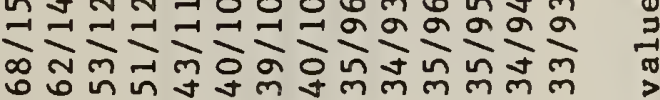
先

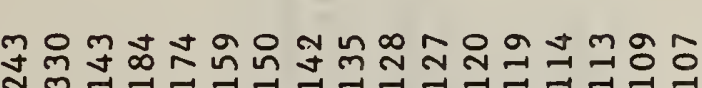

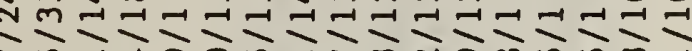

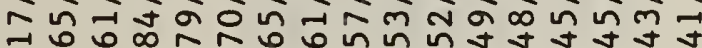
$\exists$

ปี

.

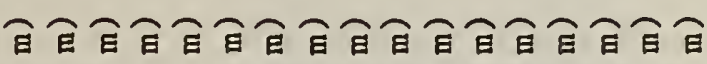

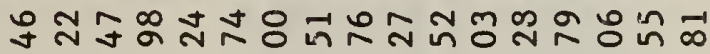

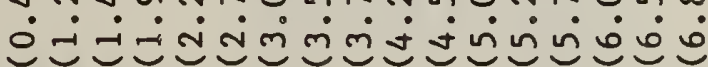

莒 莒

过 E ${ }^{\circ}>>>>>>>>>>>>>>>>>$

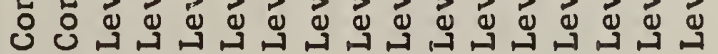

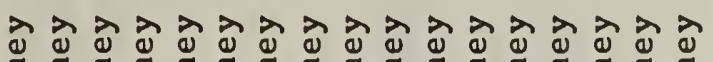

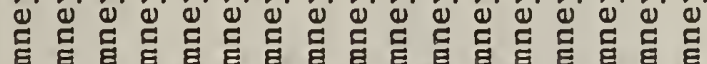

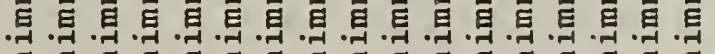

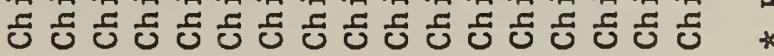




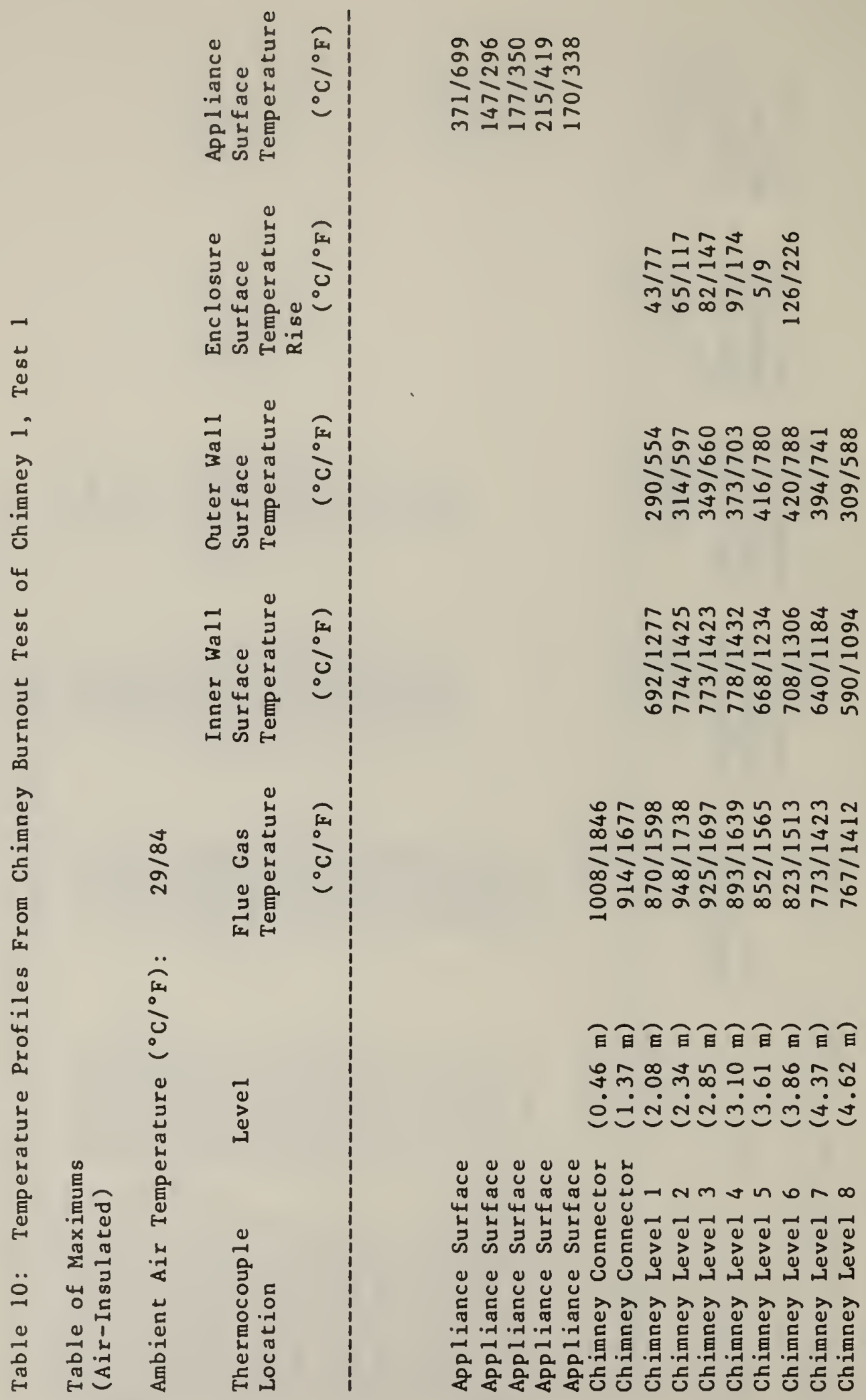




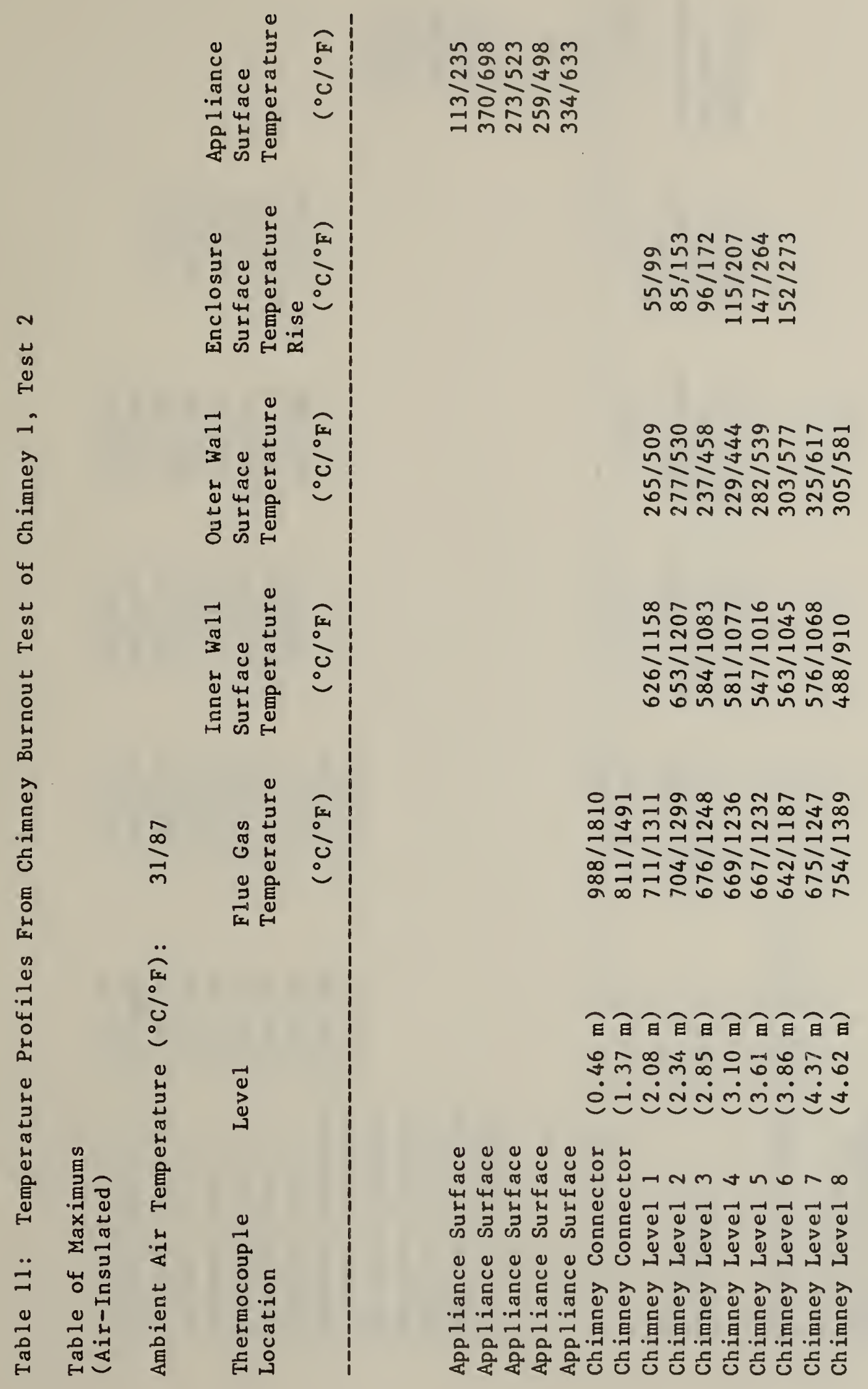




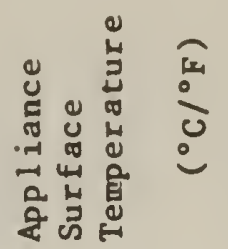

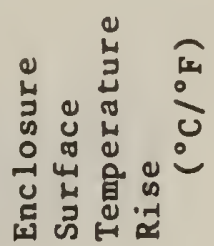

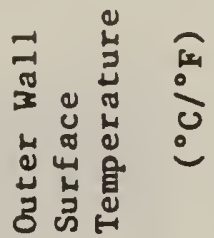

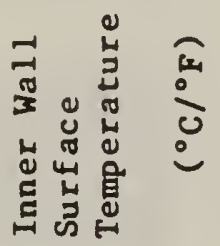

के

ำ

Iㄴำ

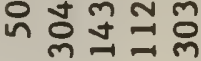

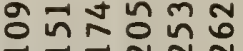

JีINลN

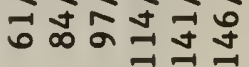

ำลํำํํำ

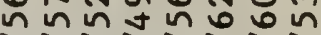

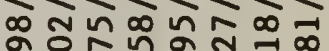

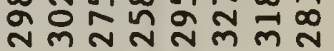

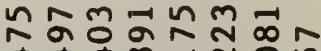

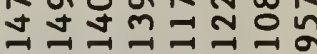
그를

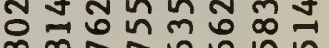

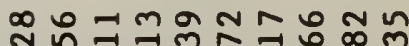

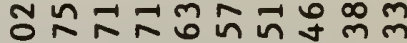

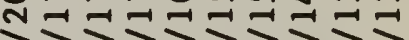

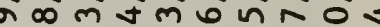

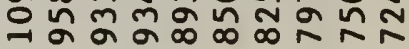

白百百百百百百

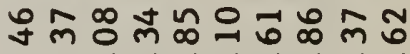

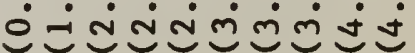

Ð 湈湈嵌岁过 ผ

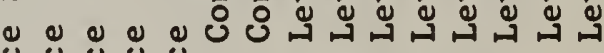
y 0 y 0

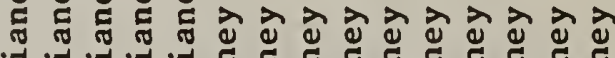

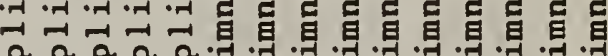

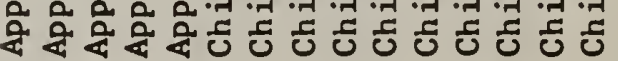




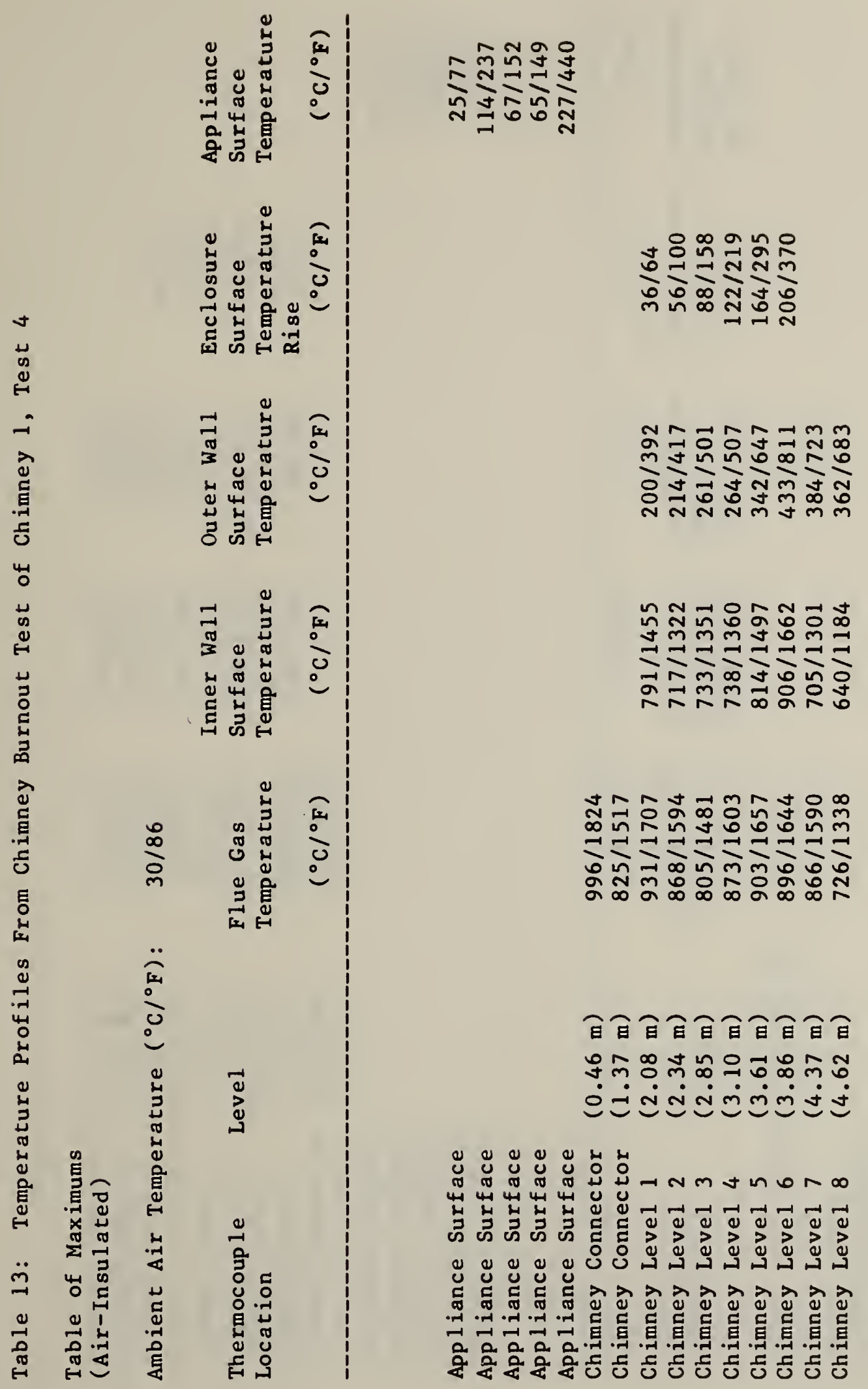




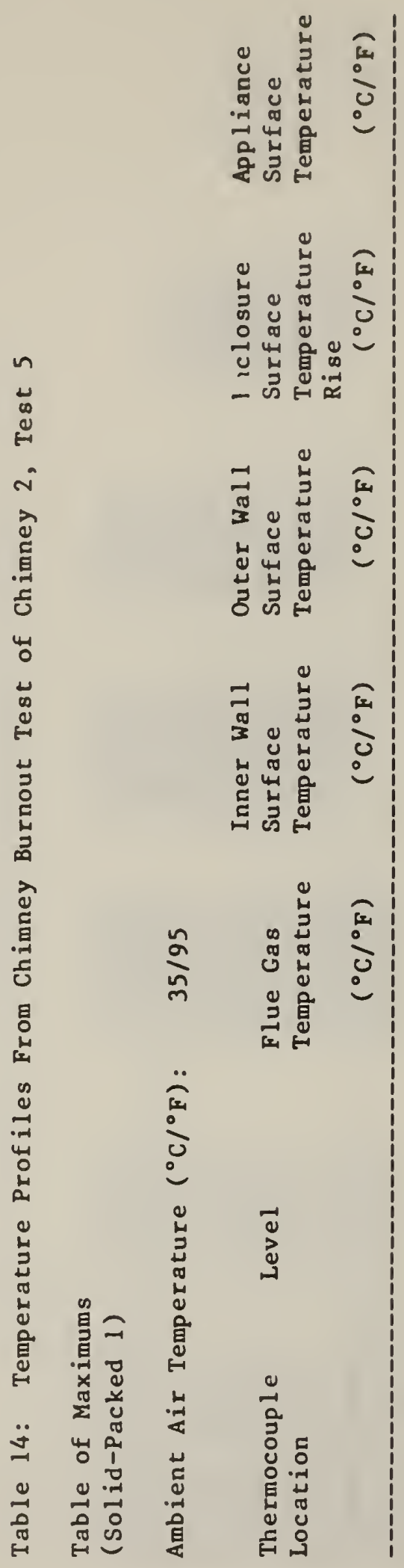

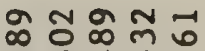

ษงษทำ

可施

กิกลัง

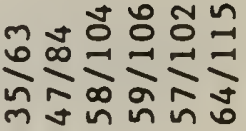

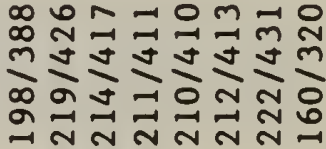

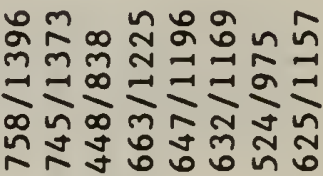

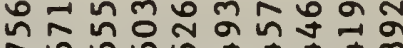
月。

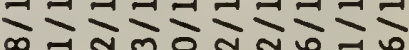
䑰

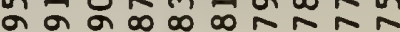

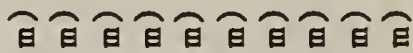
政哭

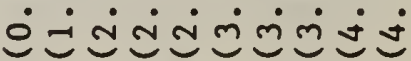

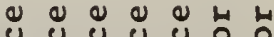

为 出

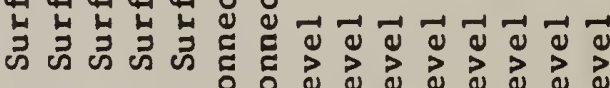
๑ ๕ टू $\breve{c}$ 近

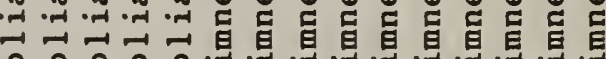

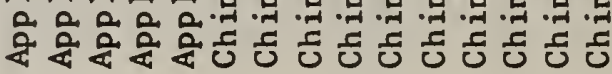




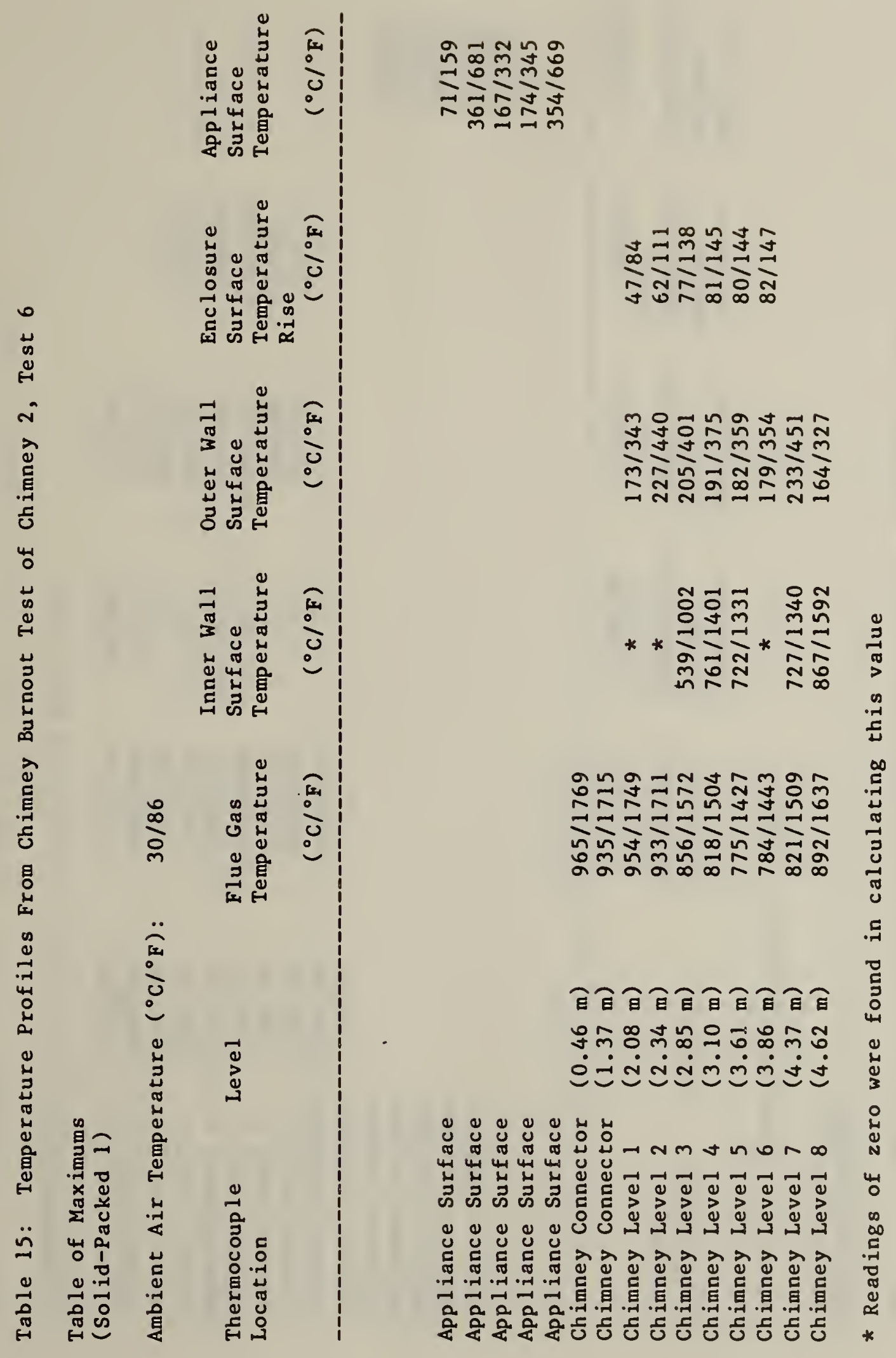




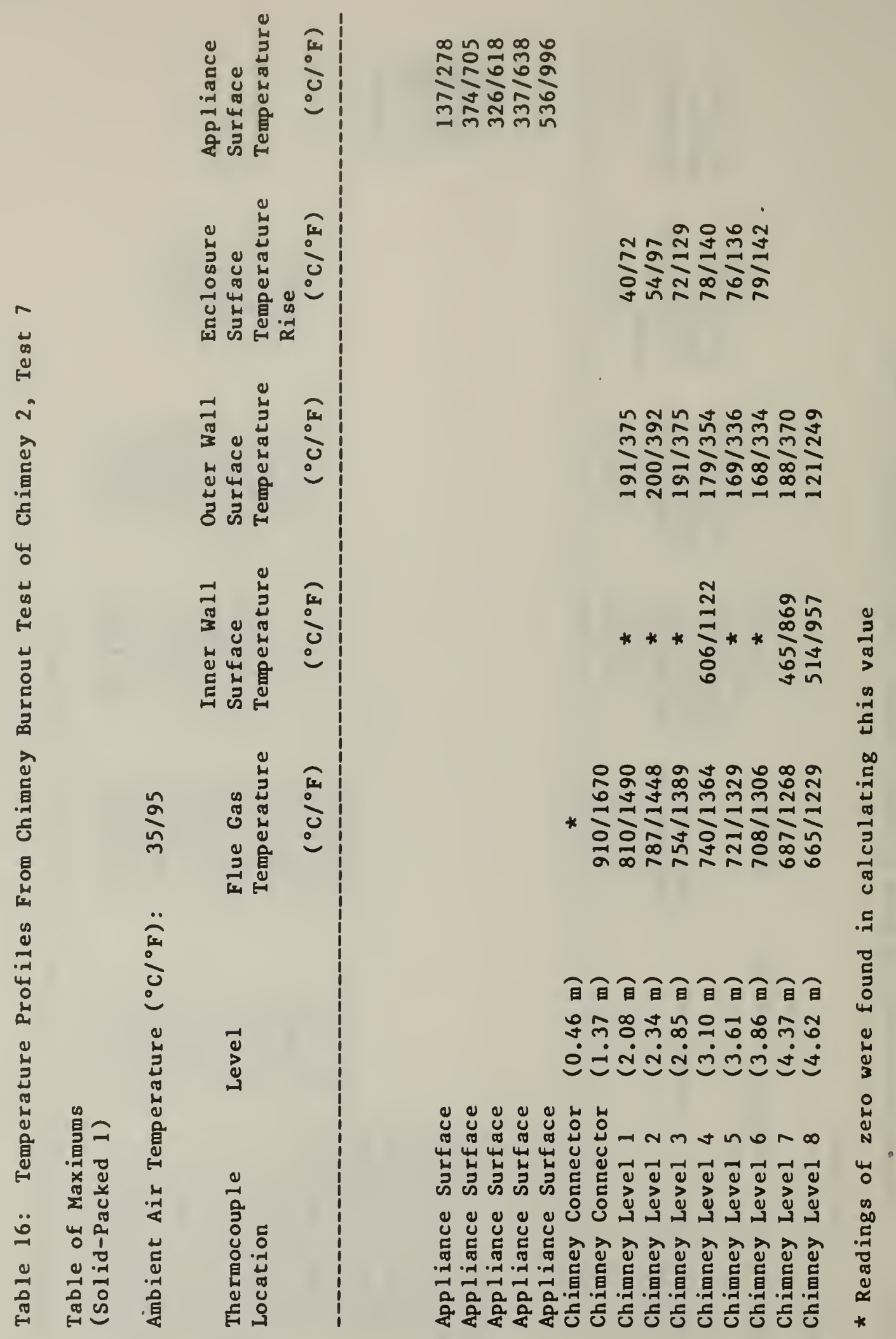




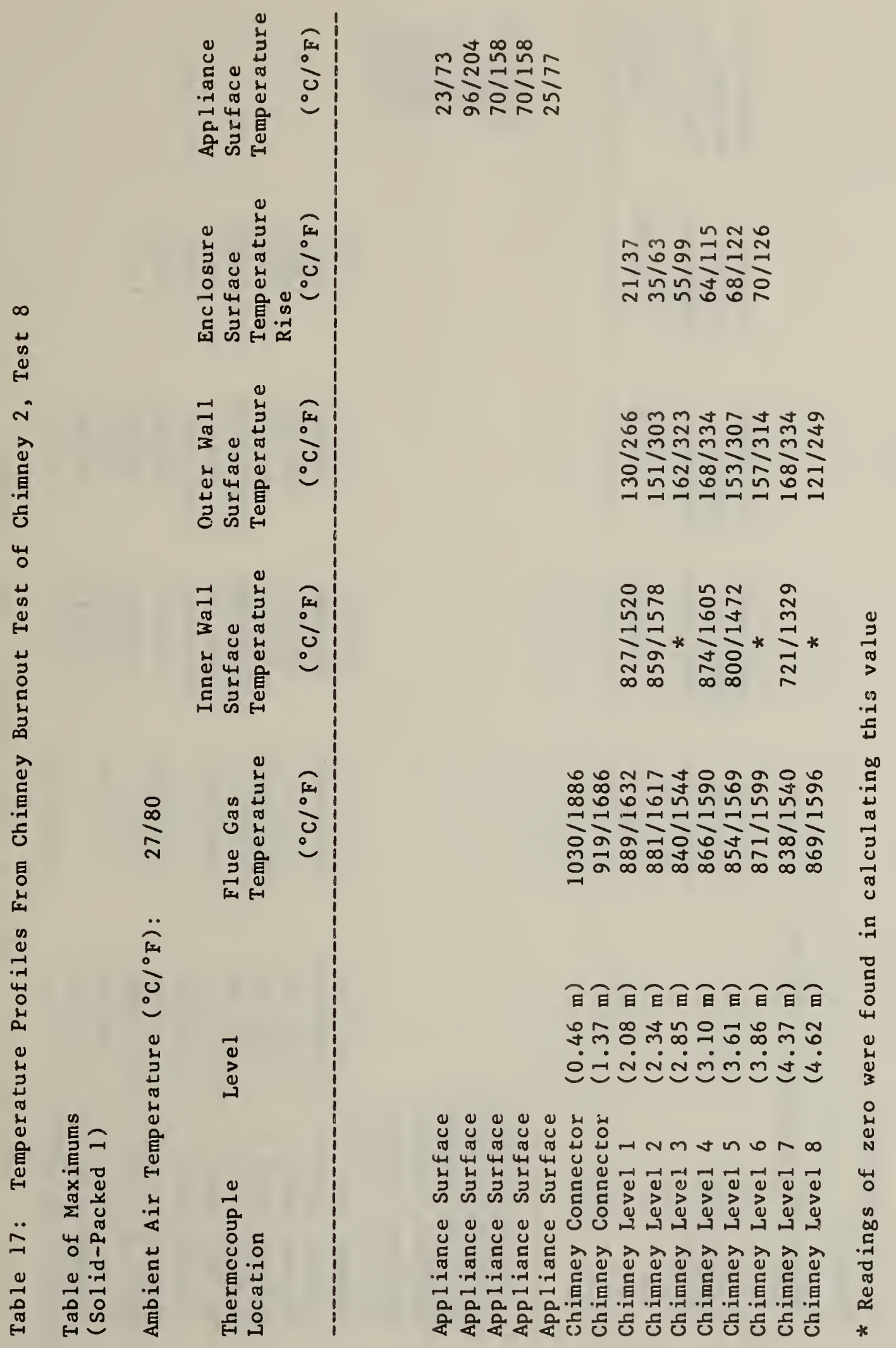




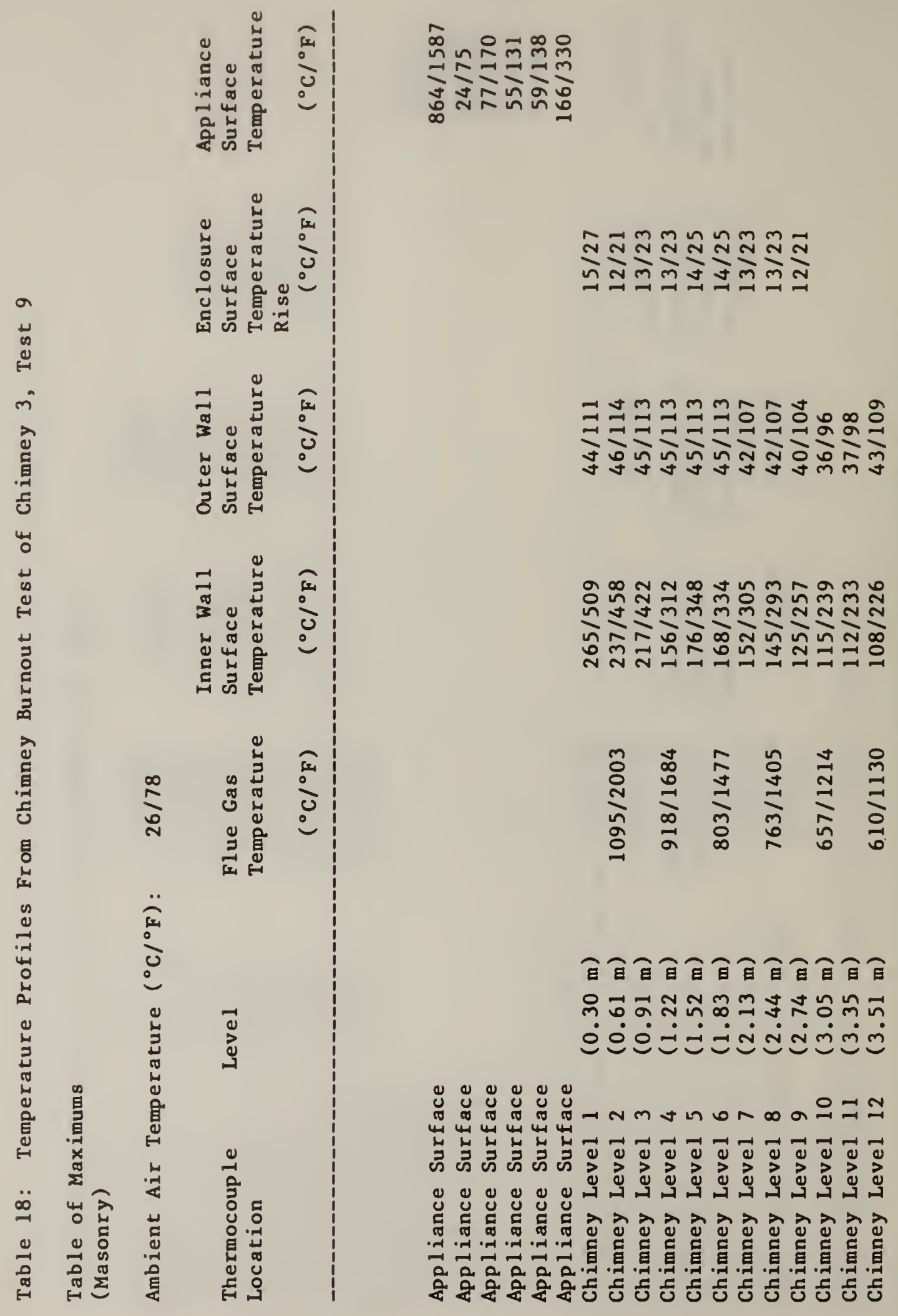




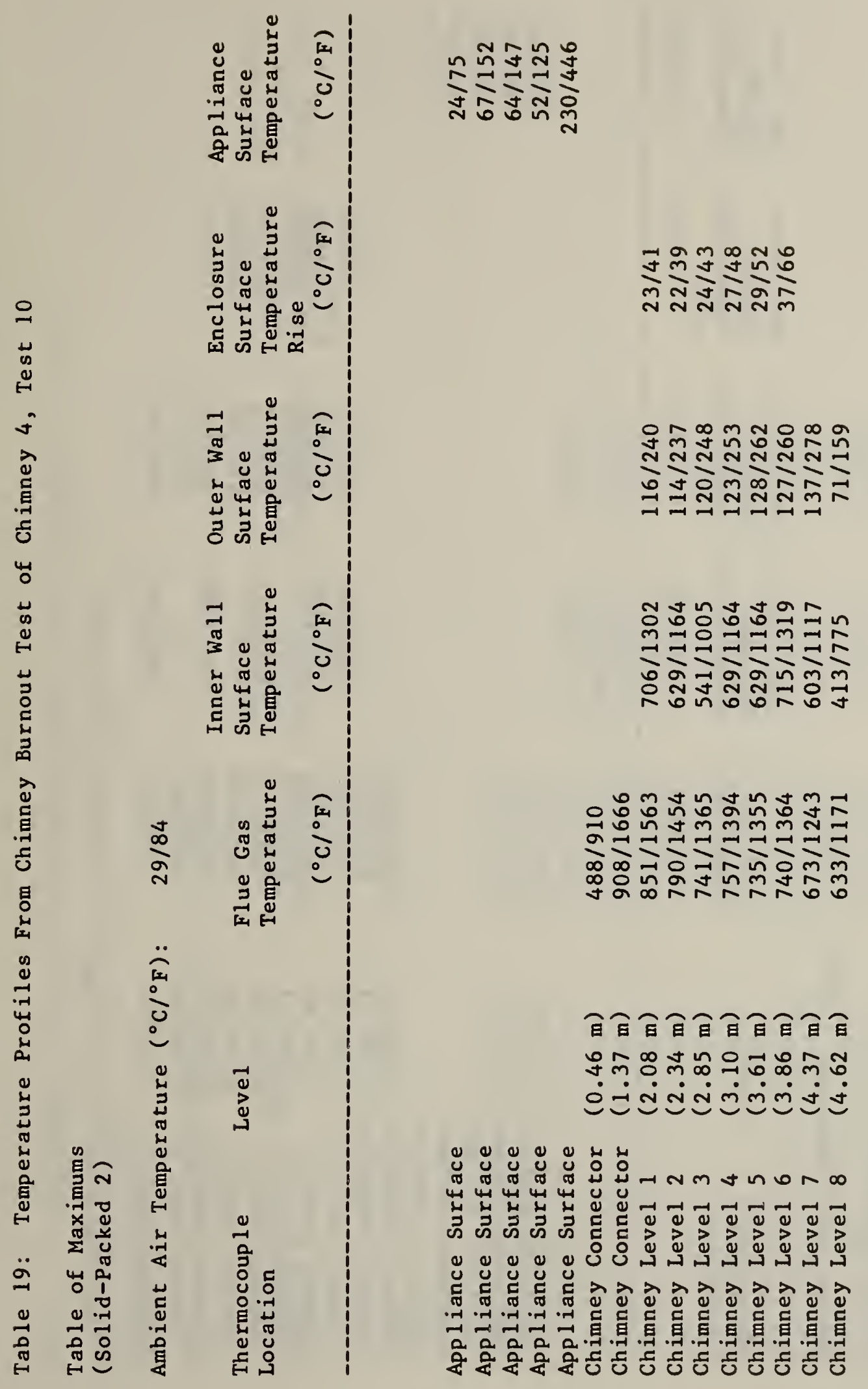




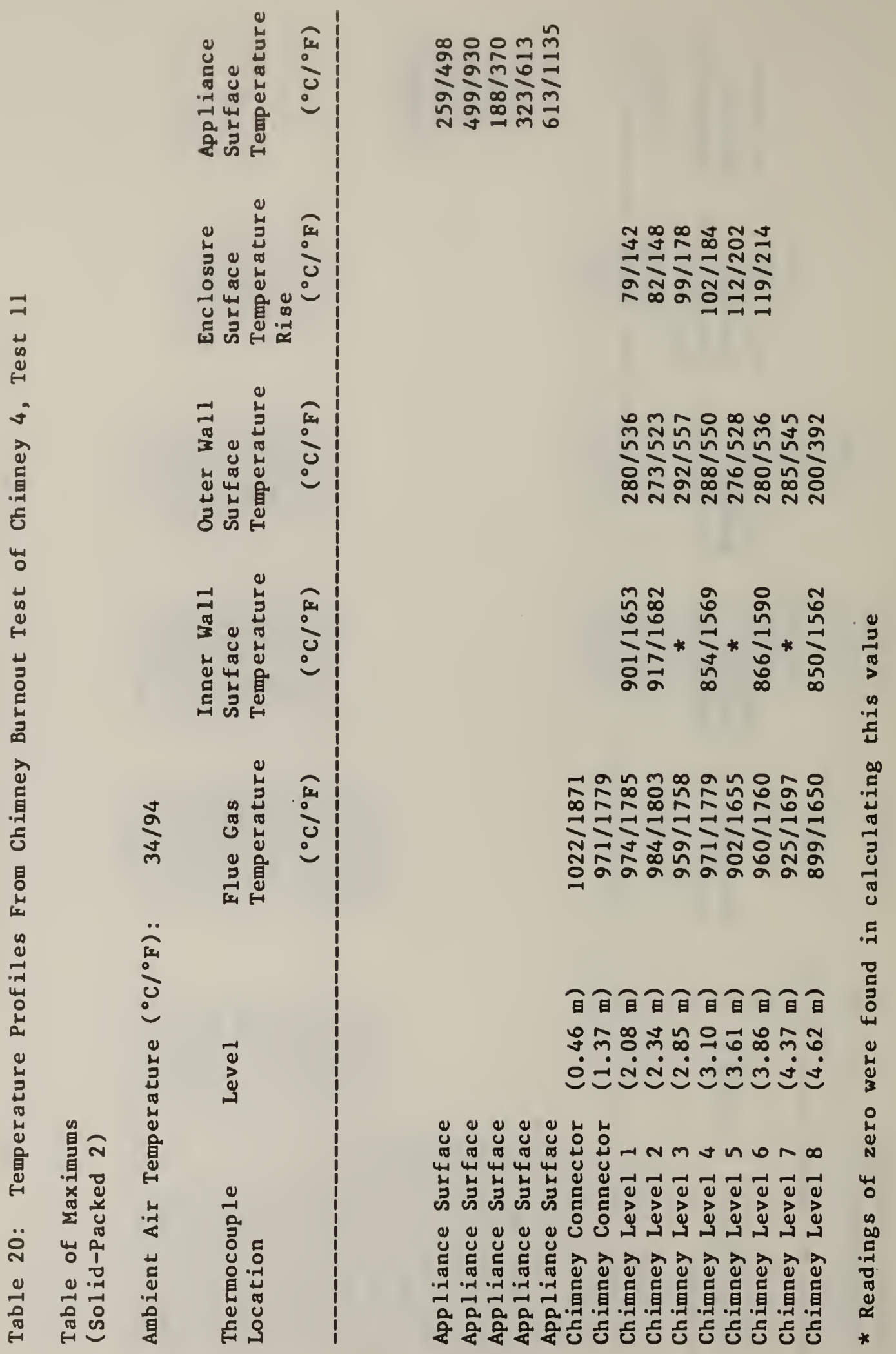




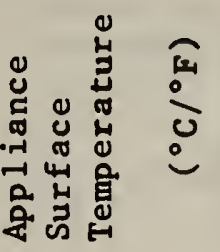

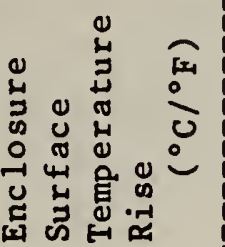
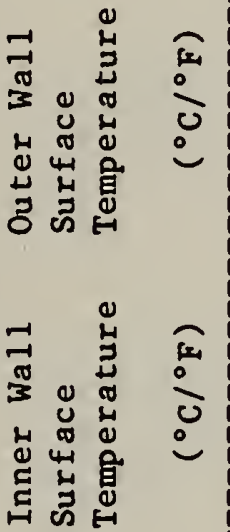

量

है⿴囗十

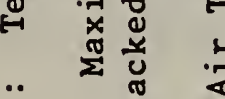

$\ddot{\sim}$

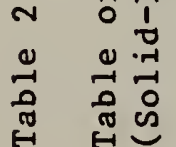

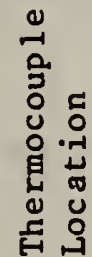

ก้

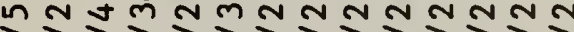

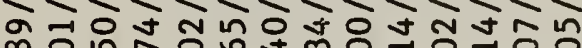

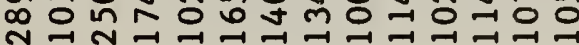

m일요 o $\infty \hat{N}$ in

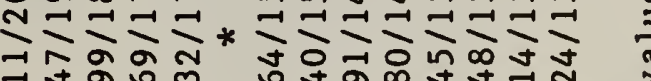

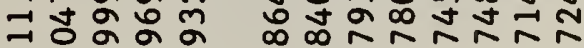

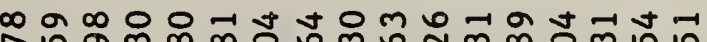

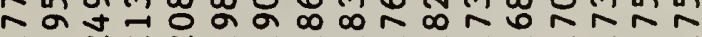

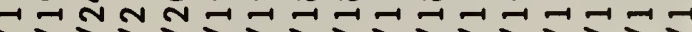
겅ㅎ 춧ㅇำ

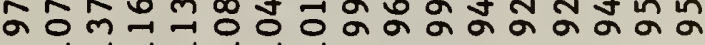

.

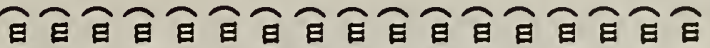

를 ษกษ

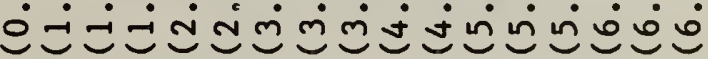

옹어

过

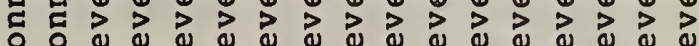

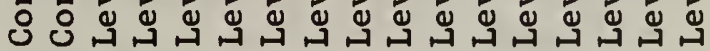

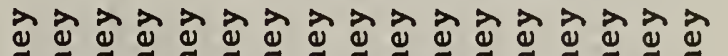

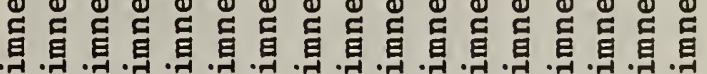
c 
Table 22

Maximum Temperatures Measured During Several Chimney Fires in Five Different Chimneys

Flue Gas Overall in Chimney

Test
Inner Chimney

Wall

$\left({ }^{\circ} \mathrm{C}\right)$
Outer Chimney

Wall

$\left({ }^{\circ} \mathrm{C}\right)$
Enclosure

$\left({ }^{\circ} \mathrm{C}\right)$

Air Insulated

Chimney

$\begin{array}{lr}1 & 1008 \\ 2 & 988 \\ 3 & 1109 \\ 4 & 996\end{array}$

948

754

934

931
902

954

810

889

1030

8

Masonry

Ch1mney

9

Solld-Packed

Chimney 非 2

10

11

908

1022

Sol1d-Packed

Chimney 非 3

1095

1095

265

46

39

222

97

858

233

112

n. $r$.

112

168

95

182

177

234

154

420
325

327

874

95

12

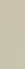




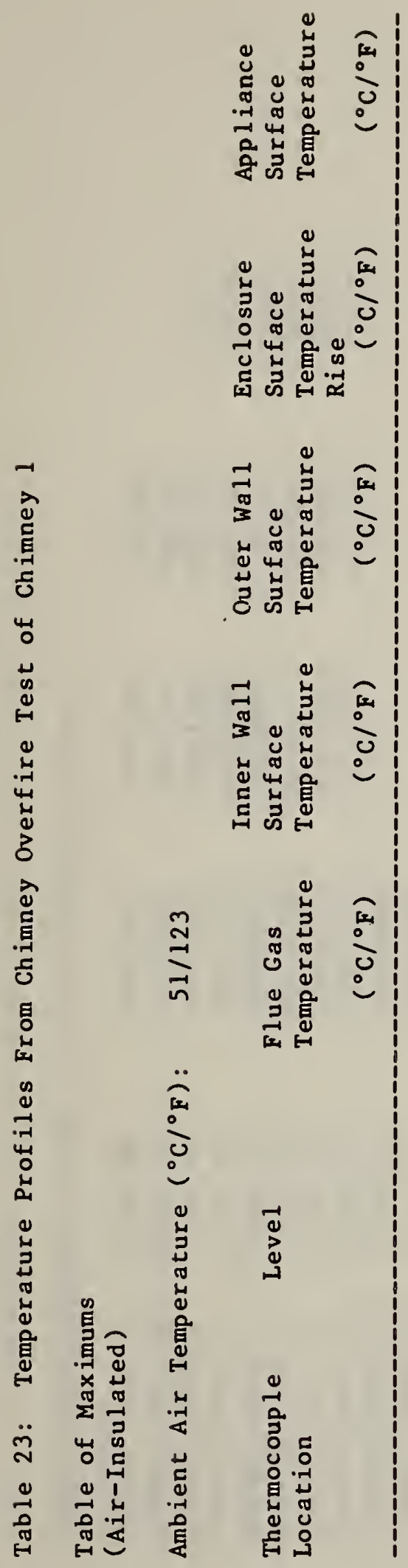

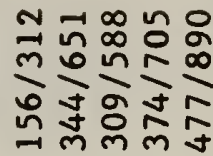

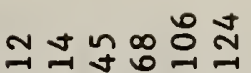

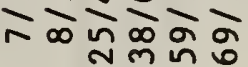

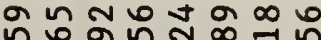

m m m

긍ㅇㅇ $\infty$ 잉

$\infty \infty$

원

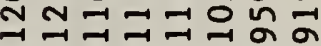

$>\vec{\nabla}>\overrightarrow{2}$

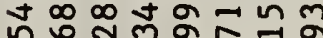
ผ

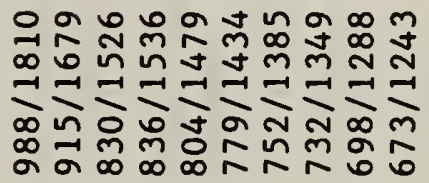

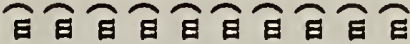

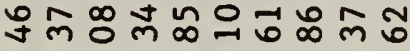

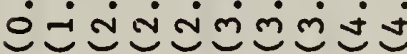

ญ

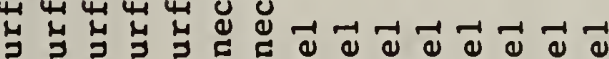

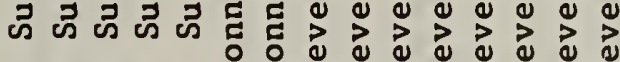
め \& \& \& \& Uूध

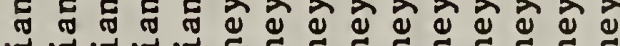

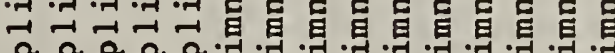

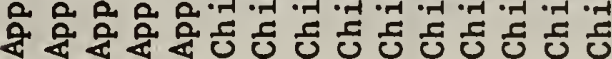


N

$\begin{array}{lll}\ddot{j} & w & 0 \\ \sim & 0 & 1 \\ 0 & 0 & 0 \\ -1 & 0 & 0 \\ \pi & 0 & 0\end{array}$

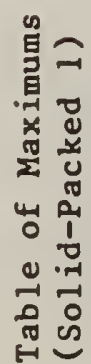

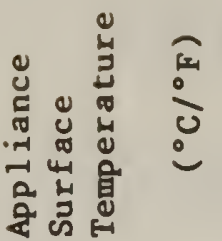
嵌

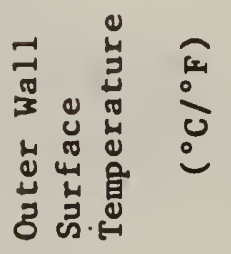

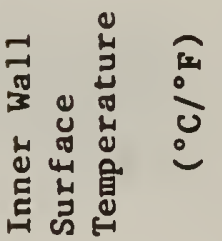

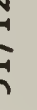

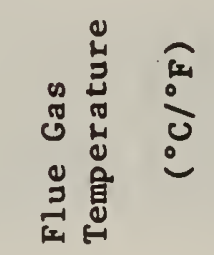

๙

긍ำ

mె

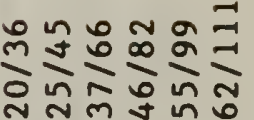

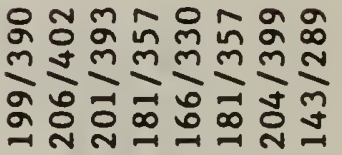

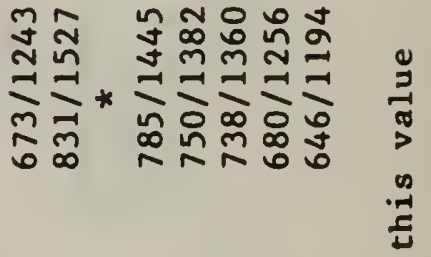

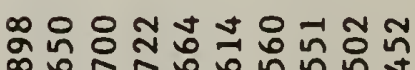

$\infty 0 \pi n$ o 0 nn

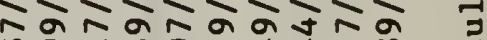
m - $\infty$ a

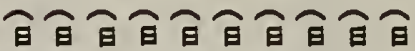

己ู ชิตั

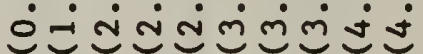

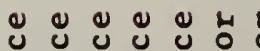

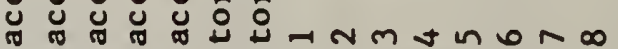

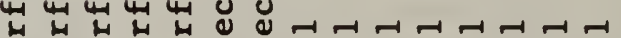

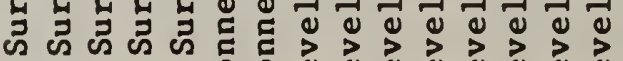

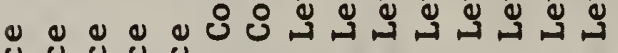
U U U

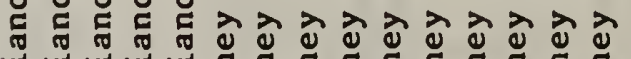

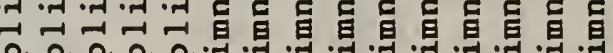
दे दे दे दे 


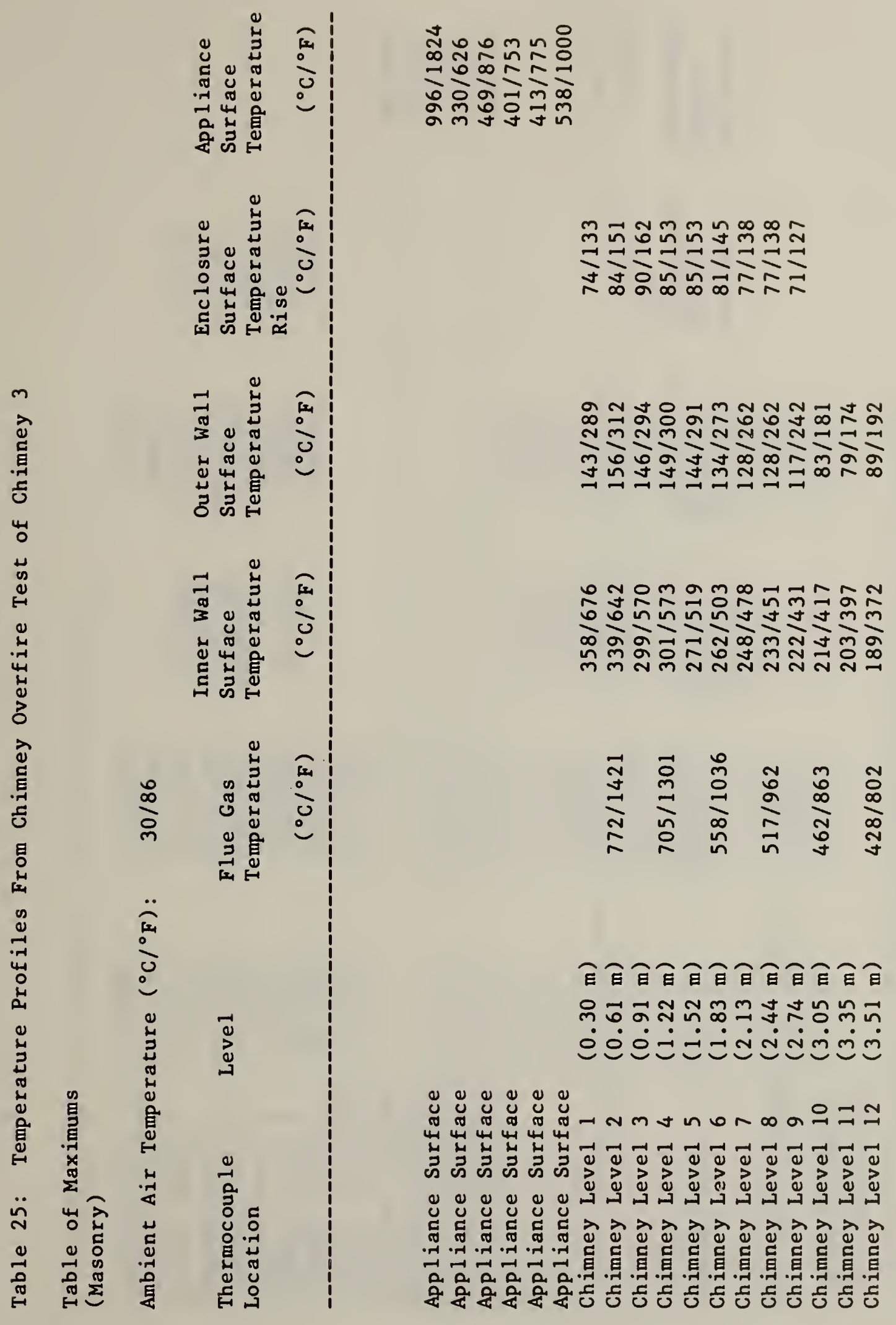




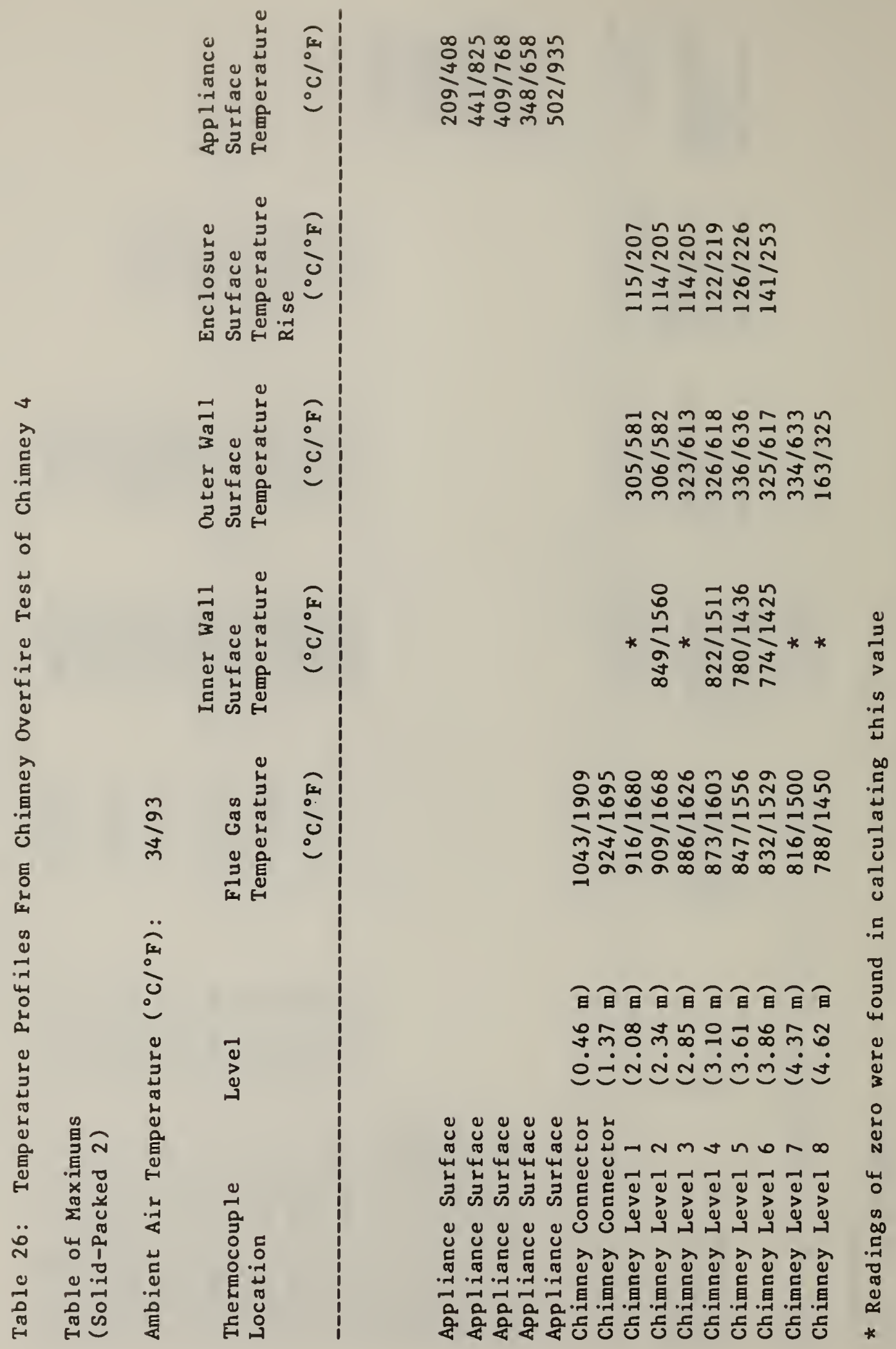




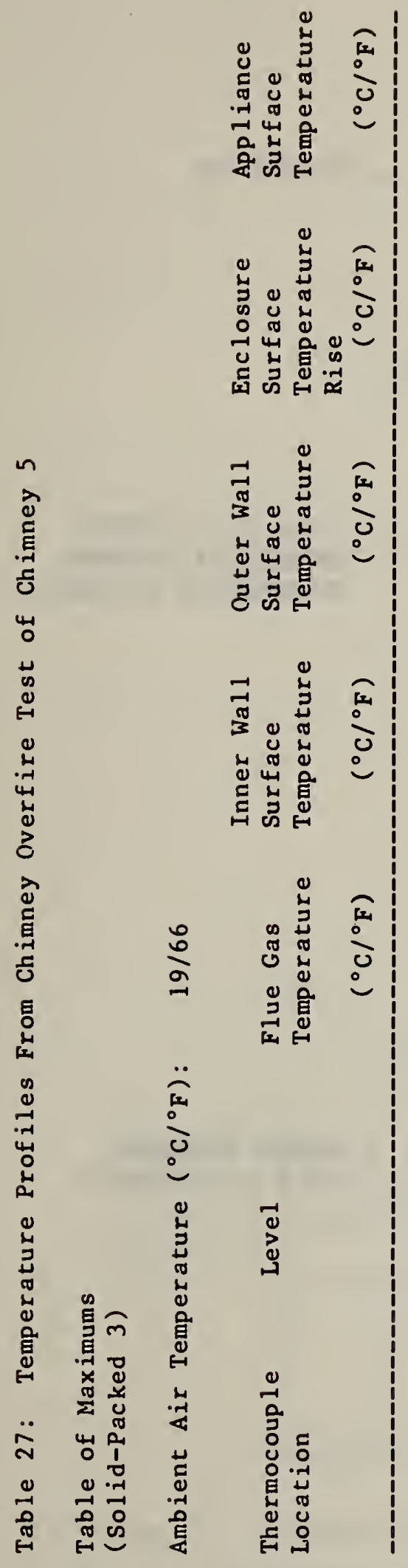

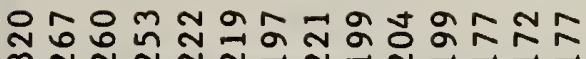

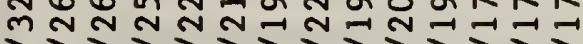

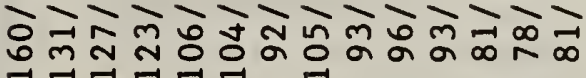

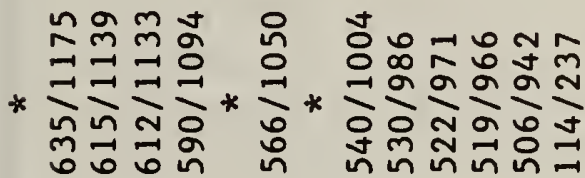

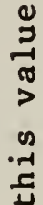

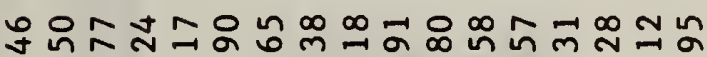

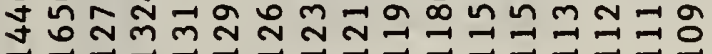

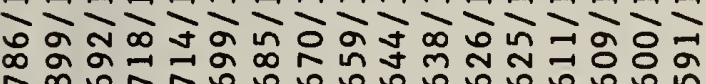
- 0 ט

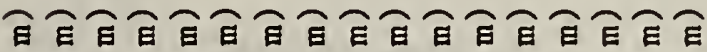
ב

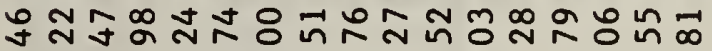

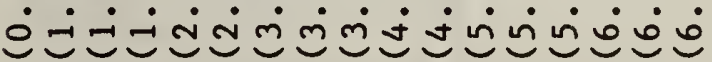

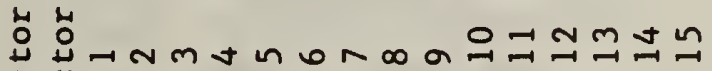

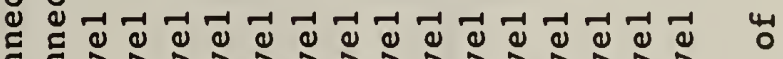

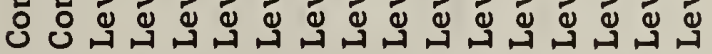

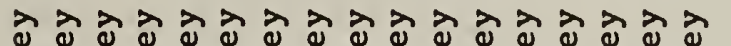

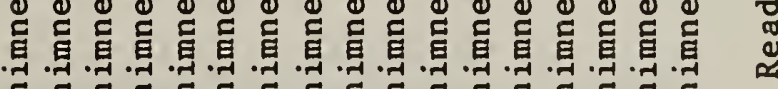

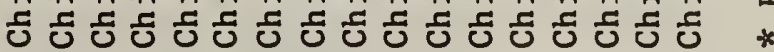




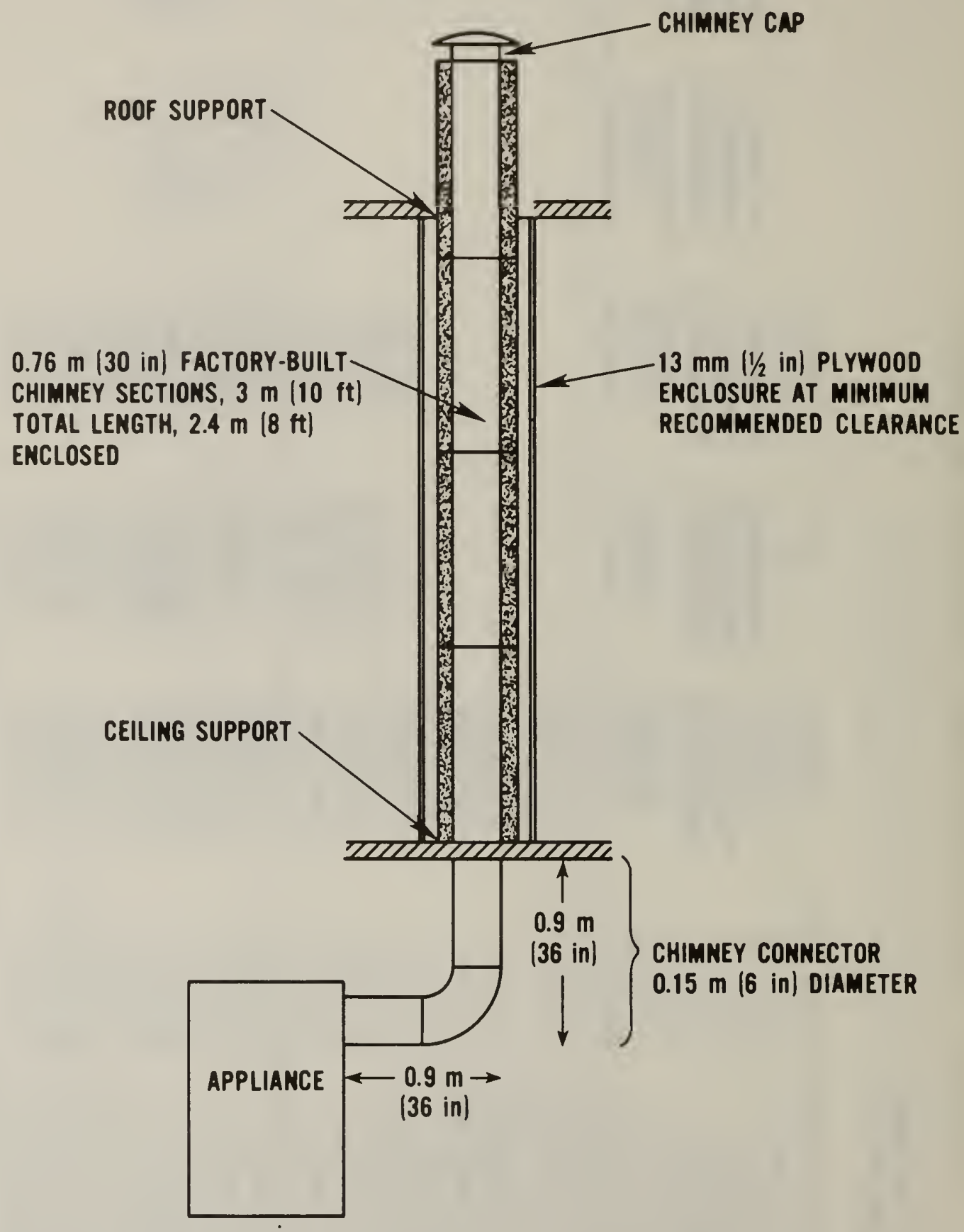

Figure 1. Installation of Factory-Built Chimneys 1, 2, and 4 for Chimney Fire Tests. 


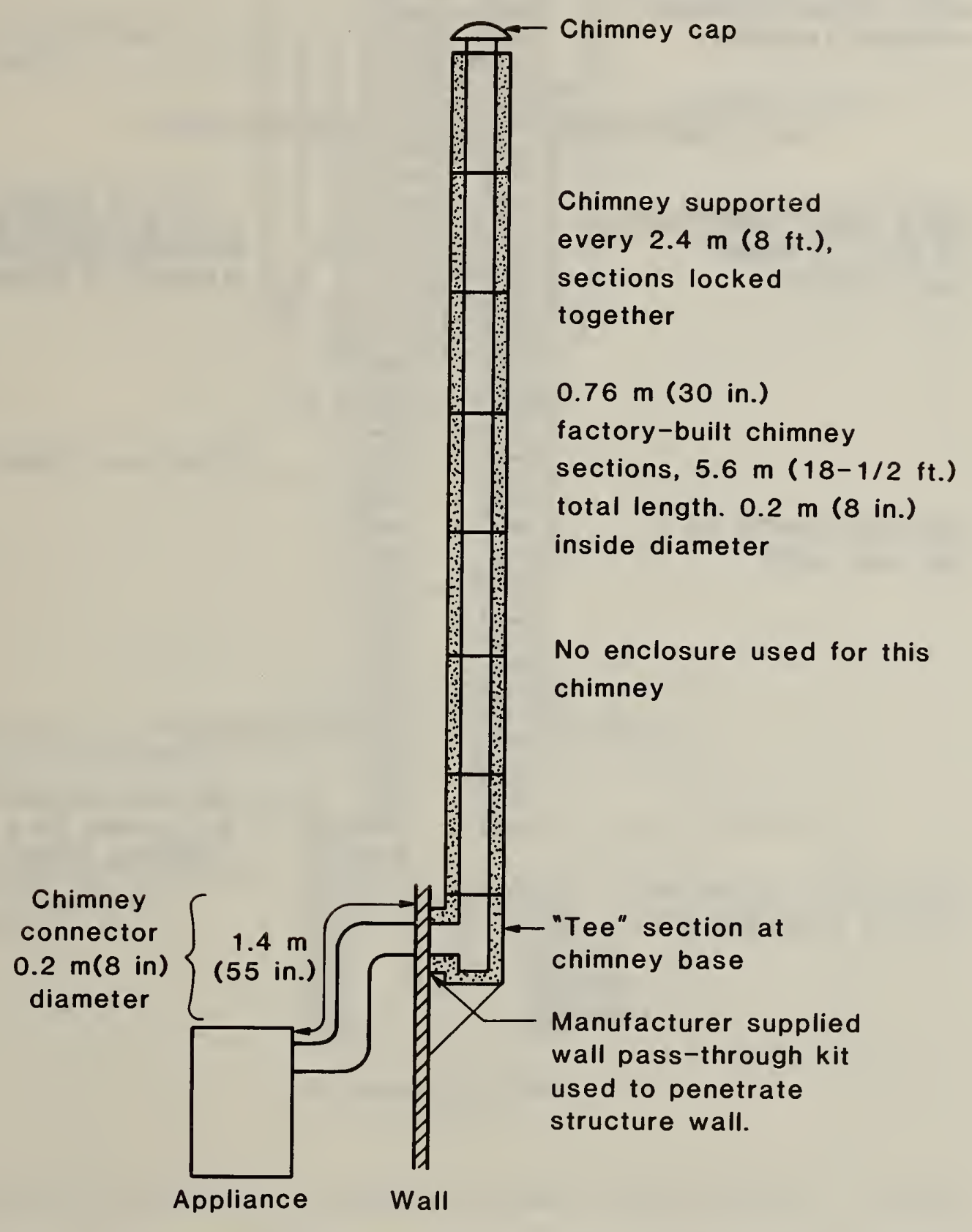

Figure 2. Installation of Factory-Built Chimney 5 for Chimney Fire Tests. 


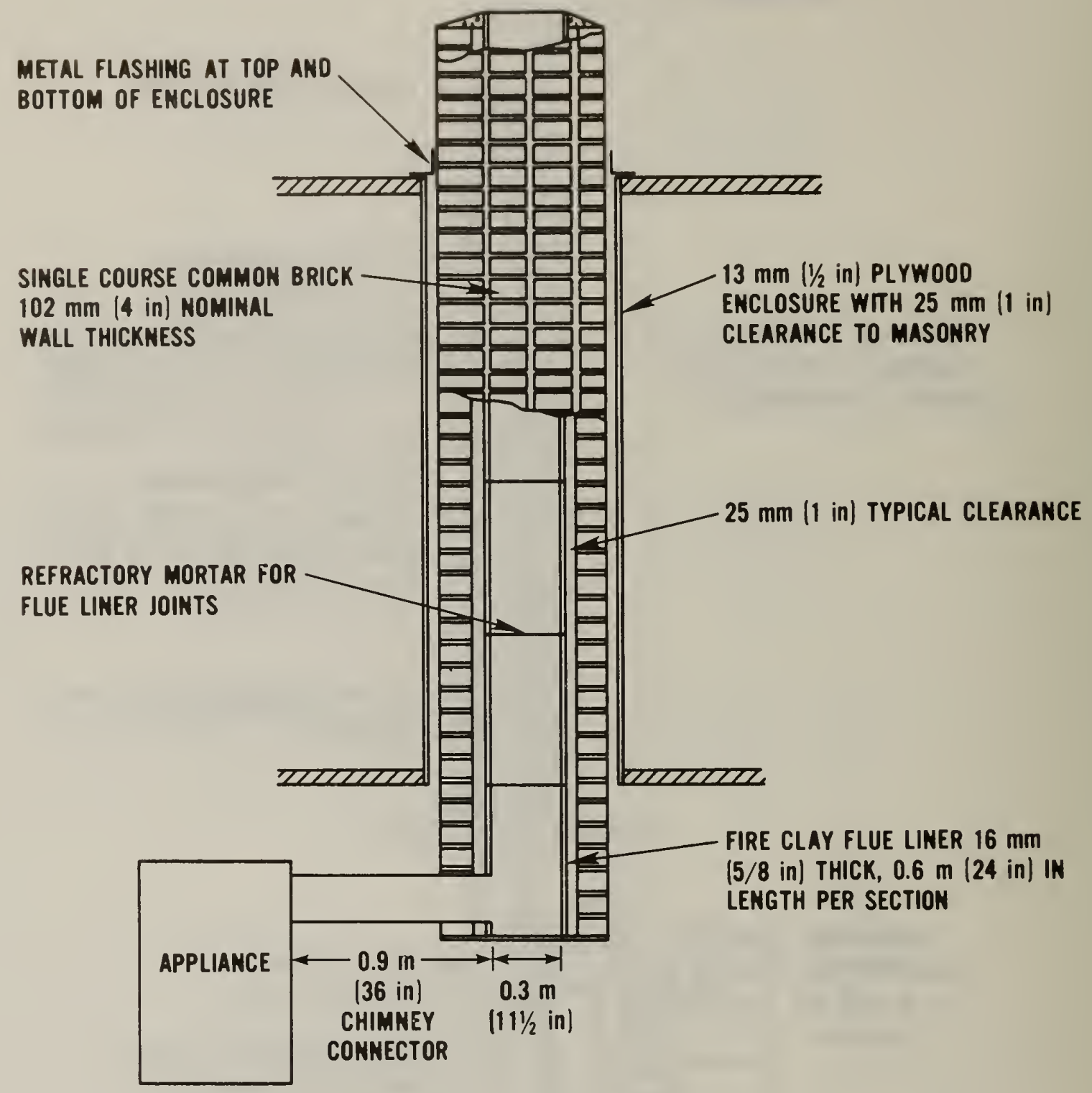

Figure 3. Installation of Masonry Chimney 3 for Chimney Fire Tests. 


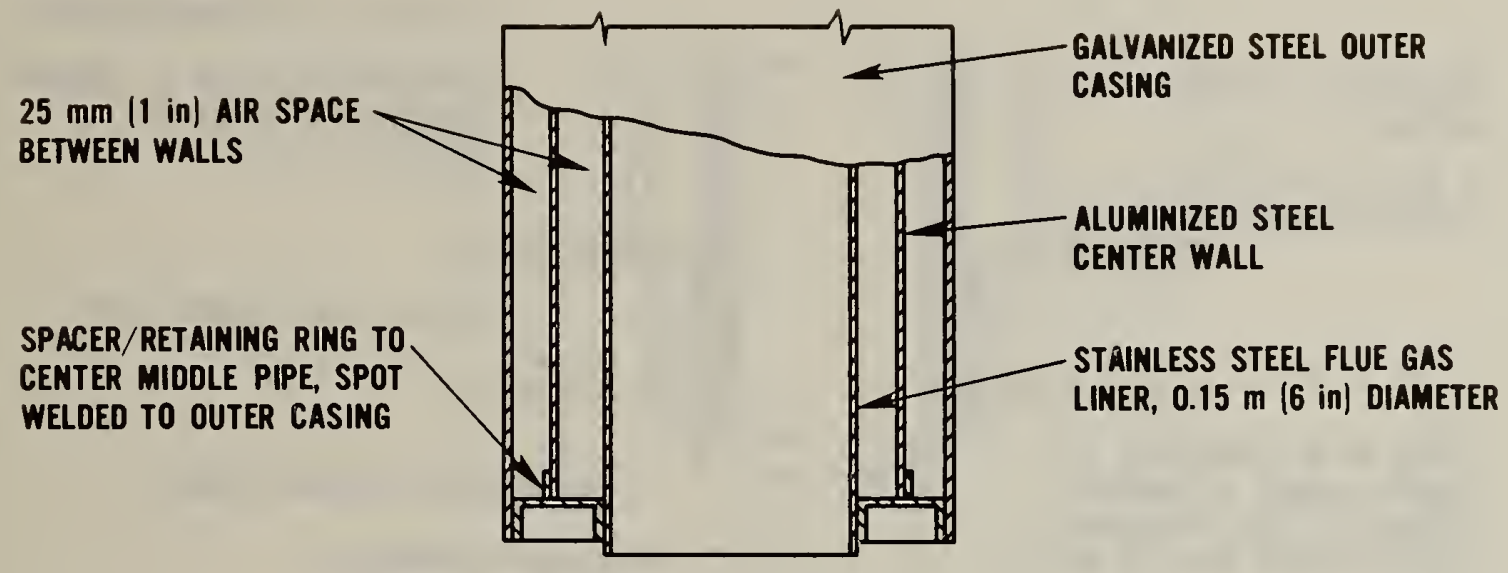

AIR INSULATED CHIMNEY

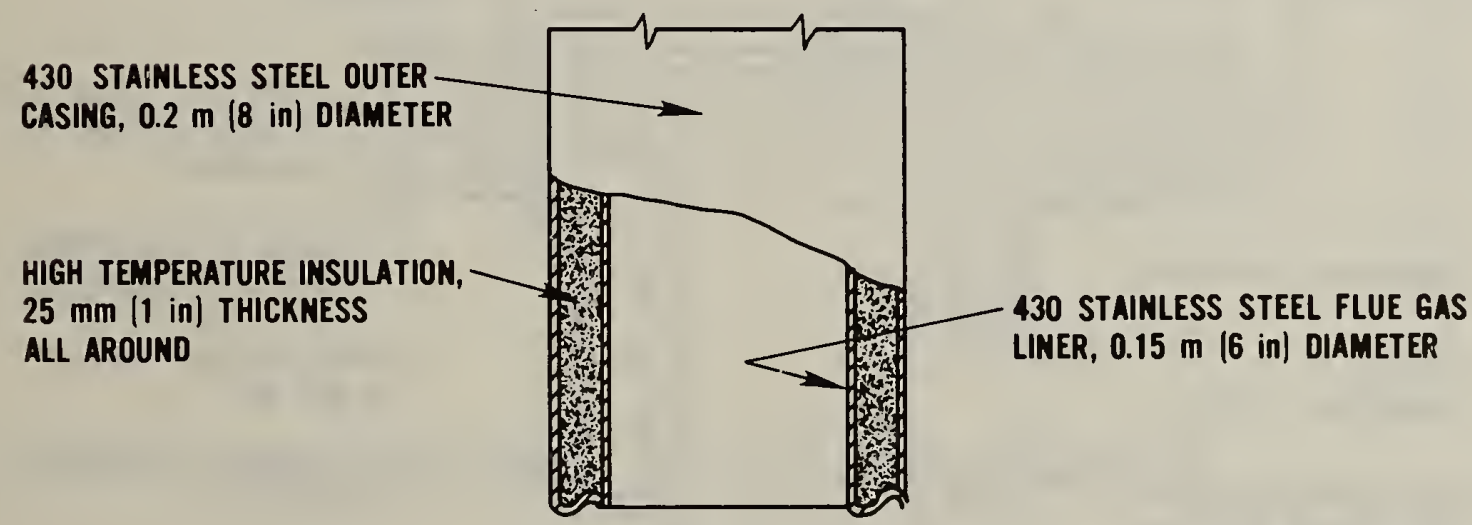

\section{SOLID-PACKED CHIMNEY}

Figure 4. Details of the Construction of the Factory-Built Chimneys Tested. 


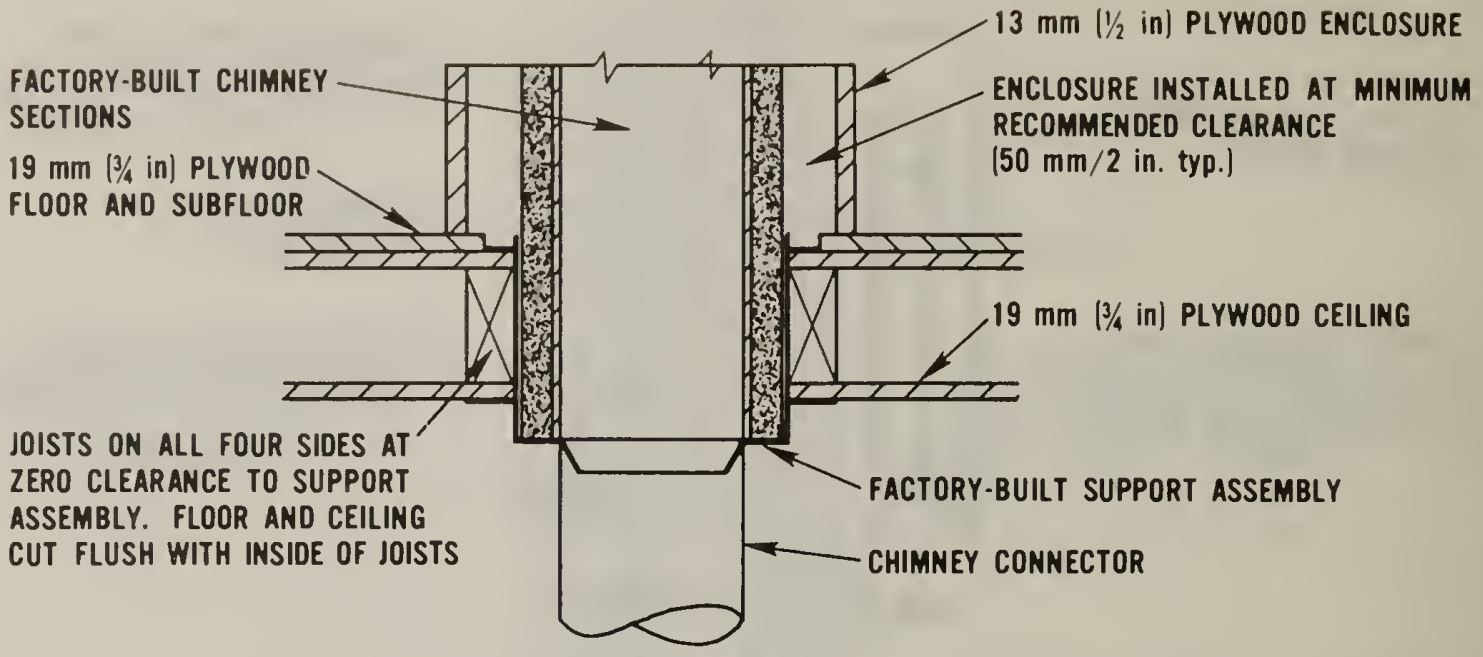

FACTORY-BUILT CHIMNEYS

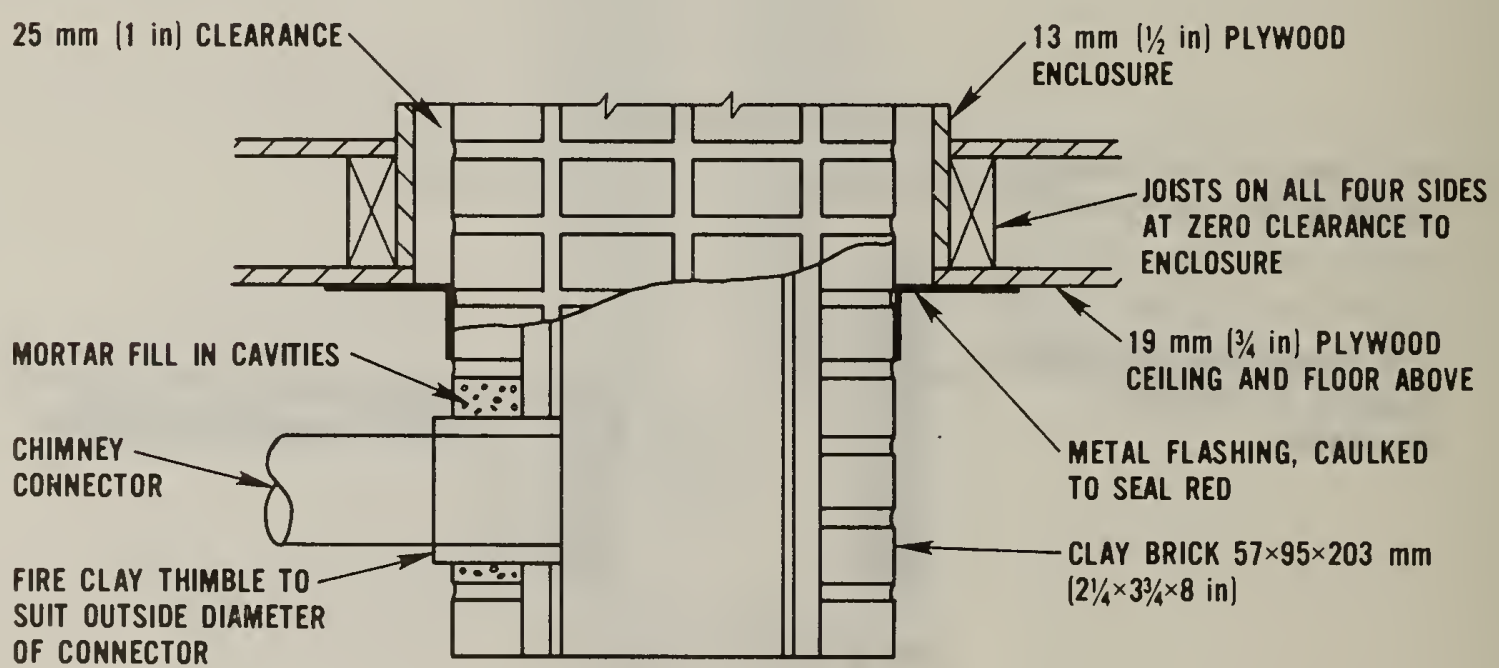

MASONRY CHIMNEYS

Figure 5. Details of the Construction of Combustible Enclosures Used to Surround Chimneys 1 through 4 . 


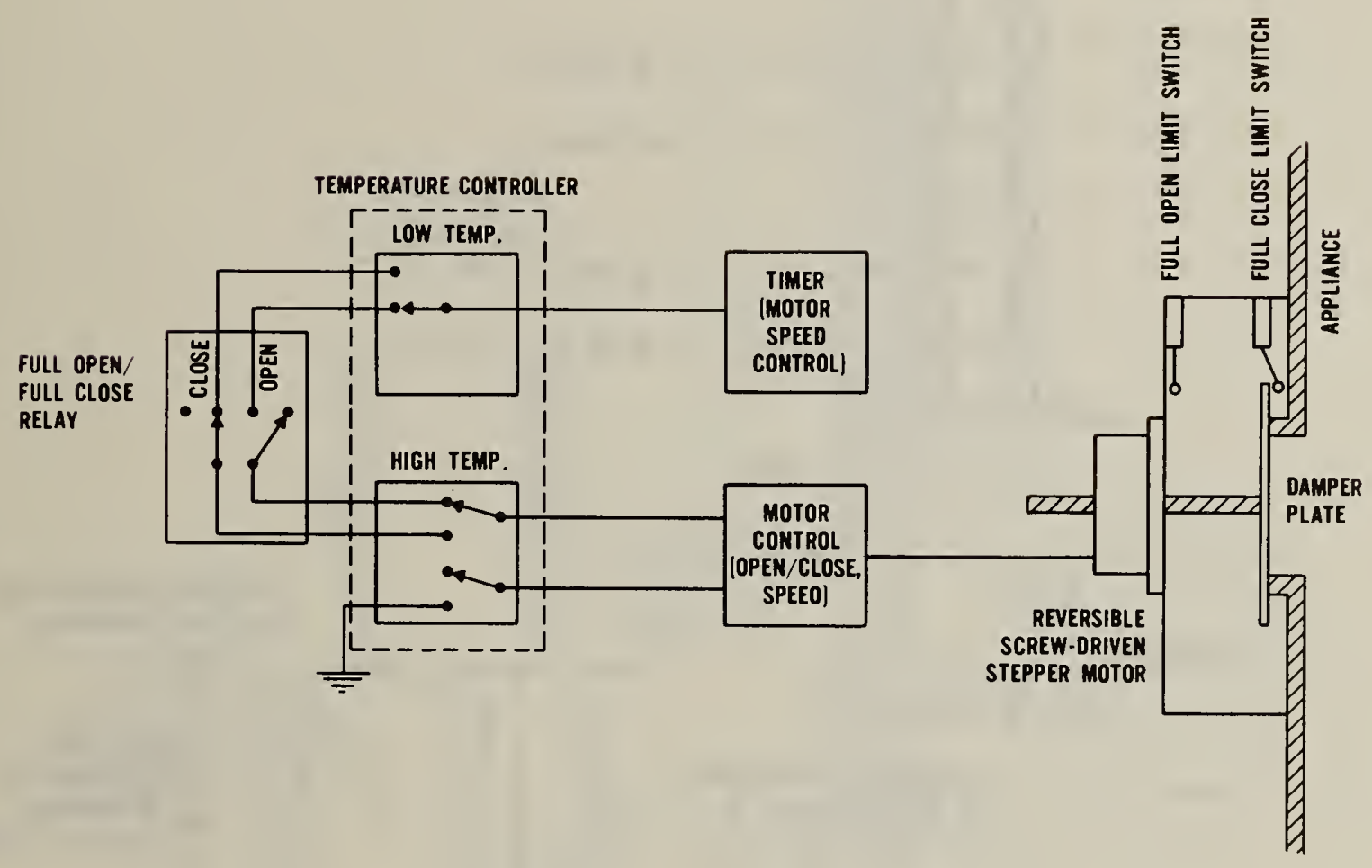

Figure 6. Temperature Control and Appliance Air Inlet Control Systems Design. 


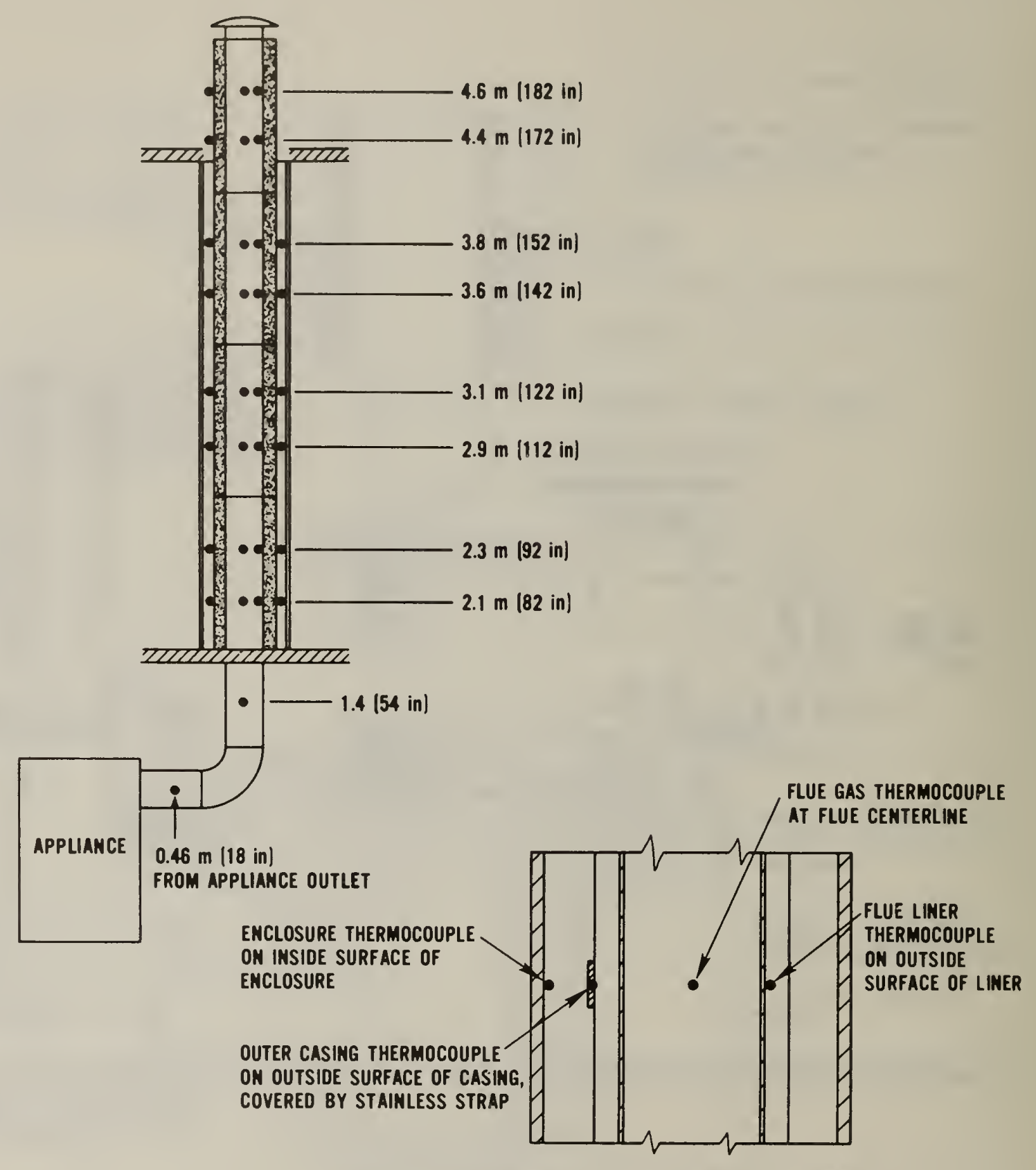

FACTORY-BUILT CHIMNEY SECTION

Figure 7. Instrumentation Locations for Tests of Factory-Built Chimneys 1,2 , and 4 . 


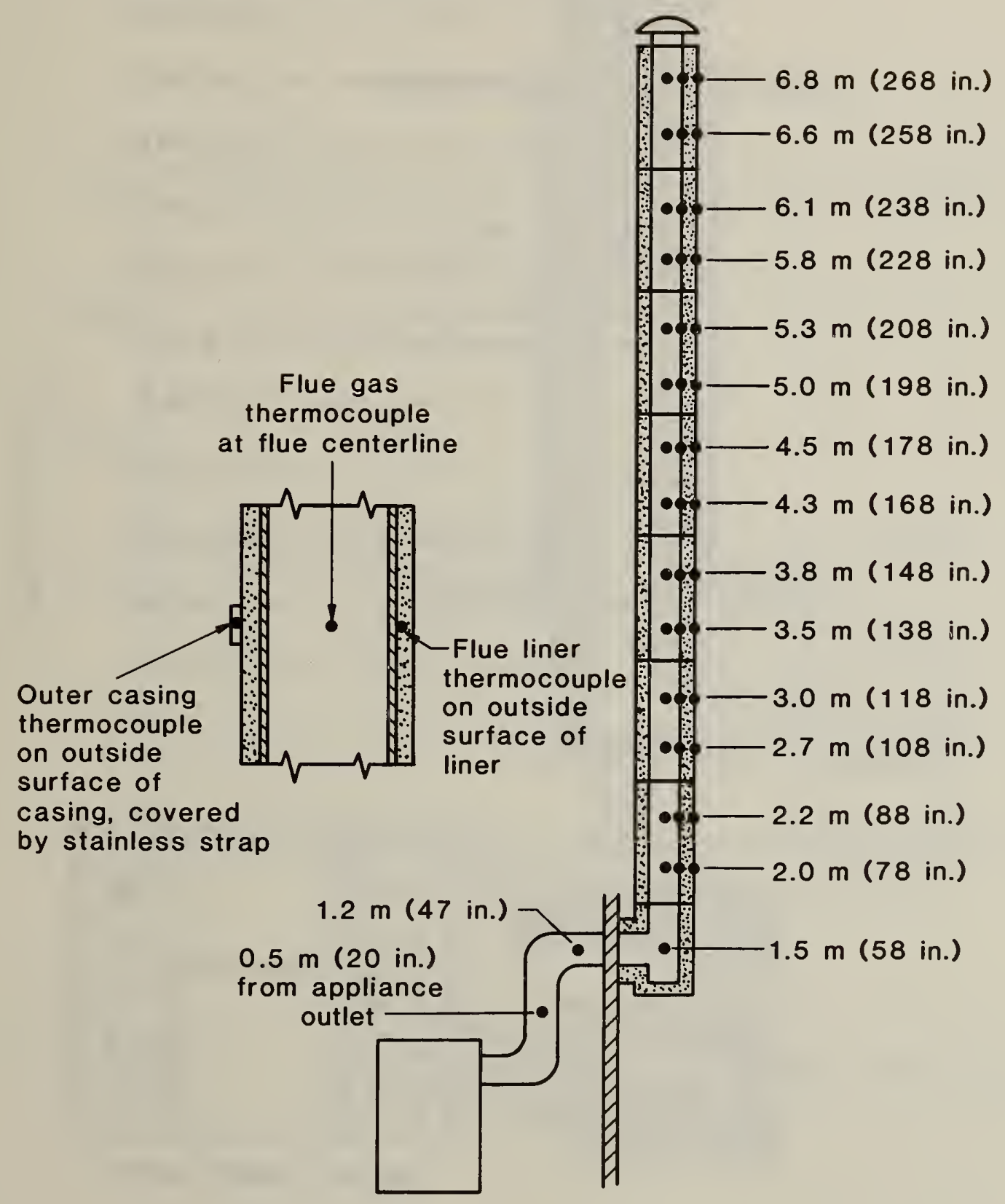

Figure 8. Instrumentation Locations for Tests of Factory Built Chimney 5. 


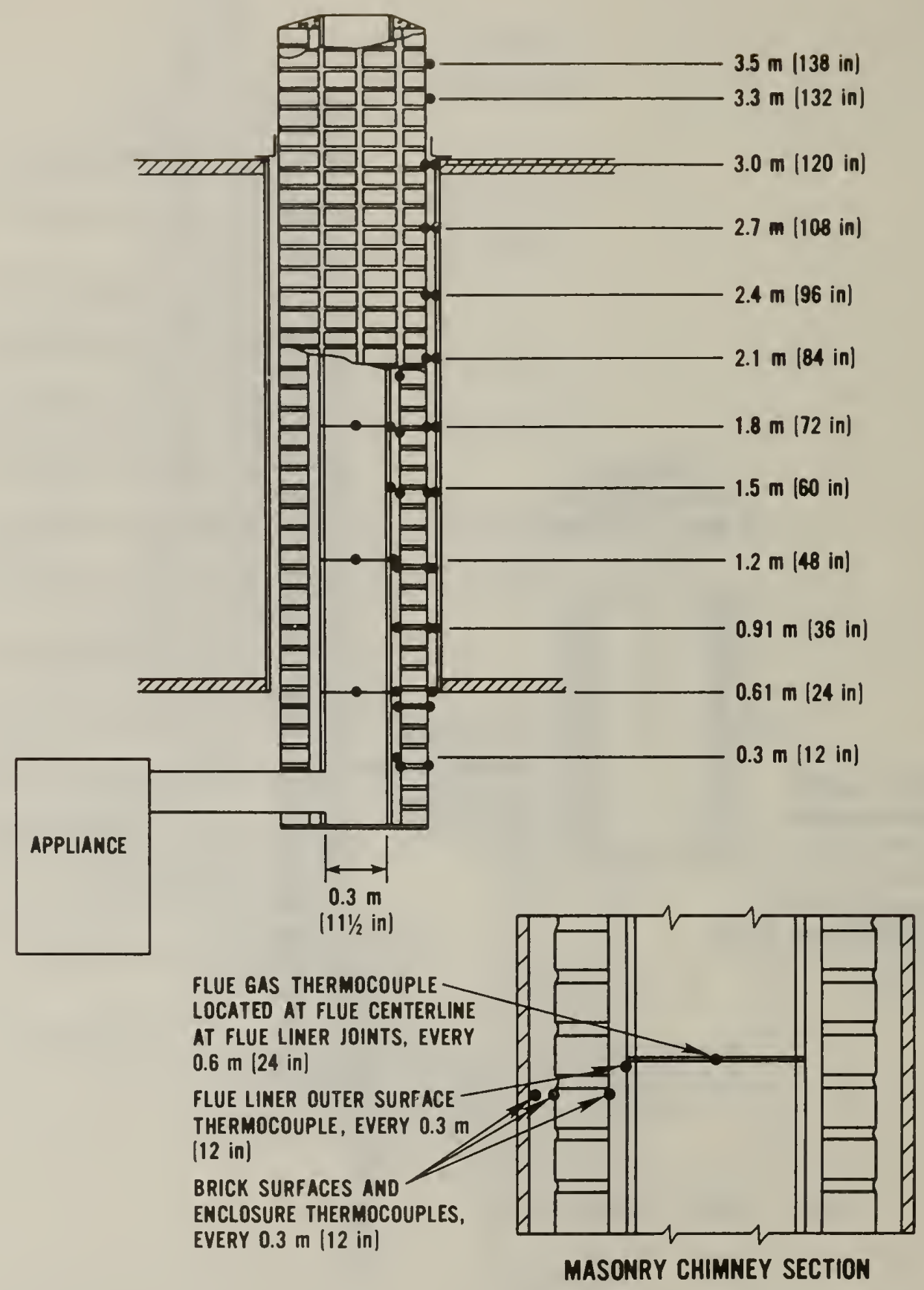

Figure 9. Instrumentation Locations for Tests of Masonry Chimney 3. 


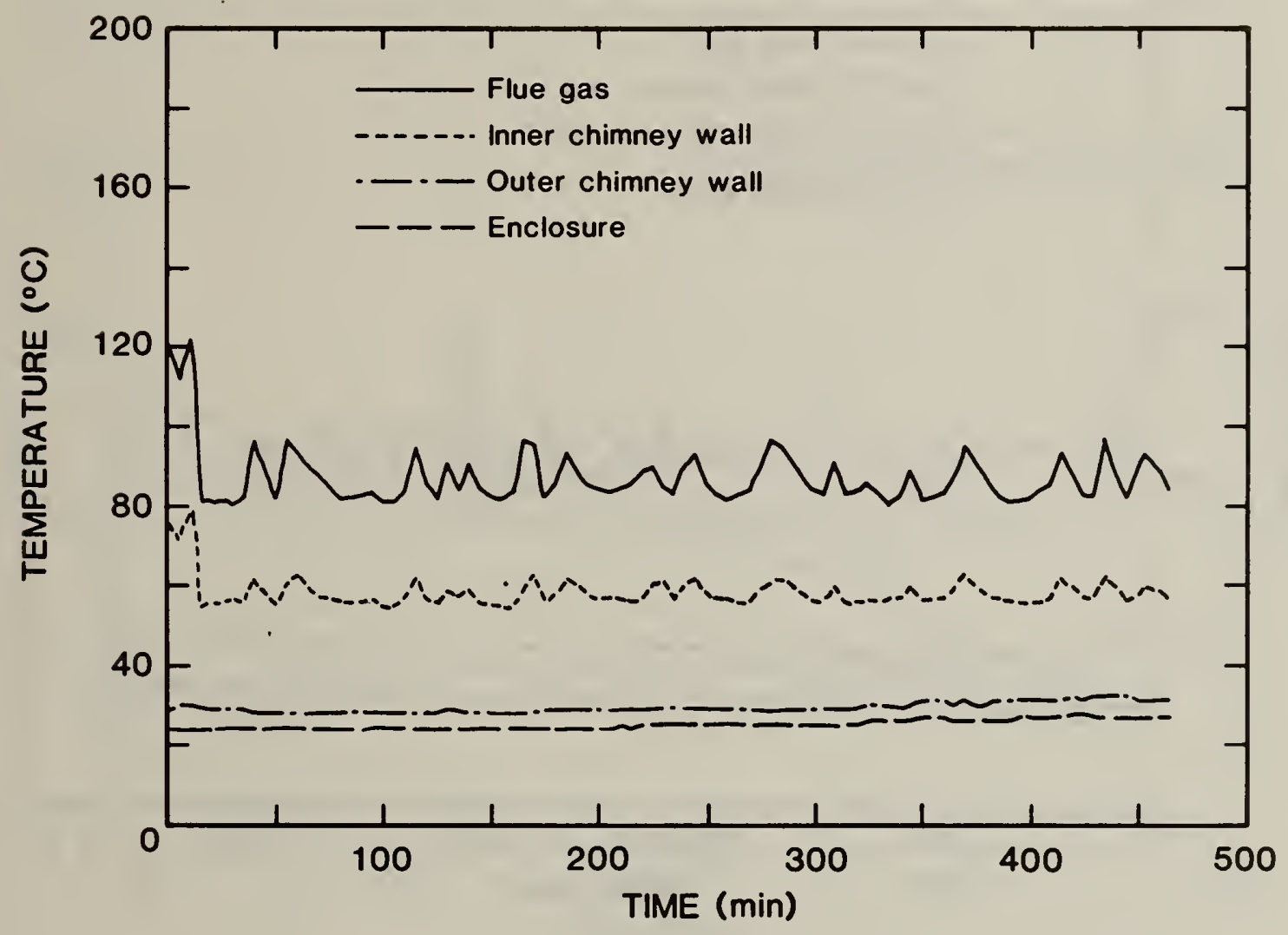

Figure 10. Temperatures at Chimney Base During Creosoting Buildup Test of Chimney 1. 


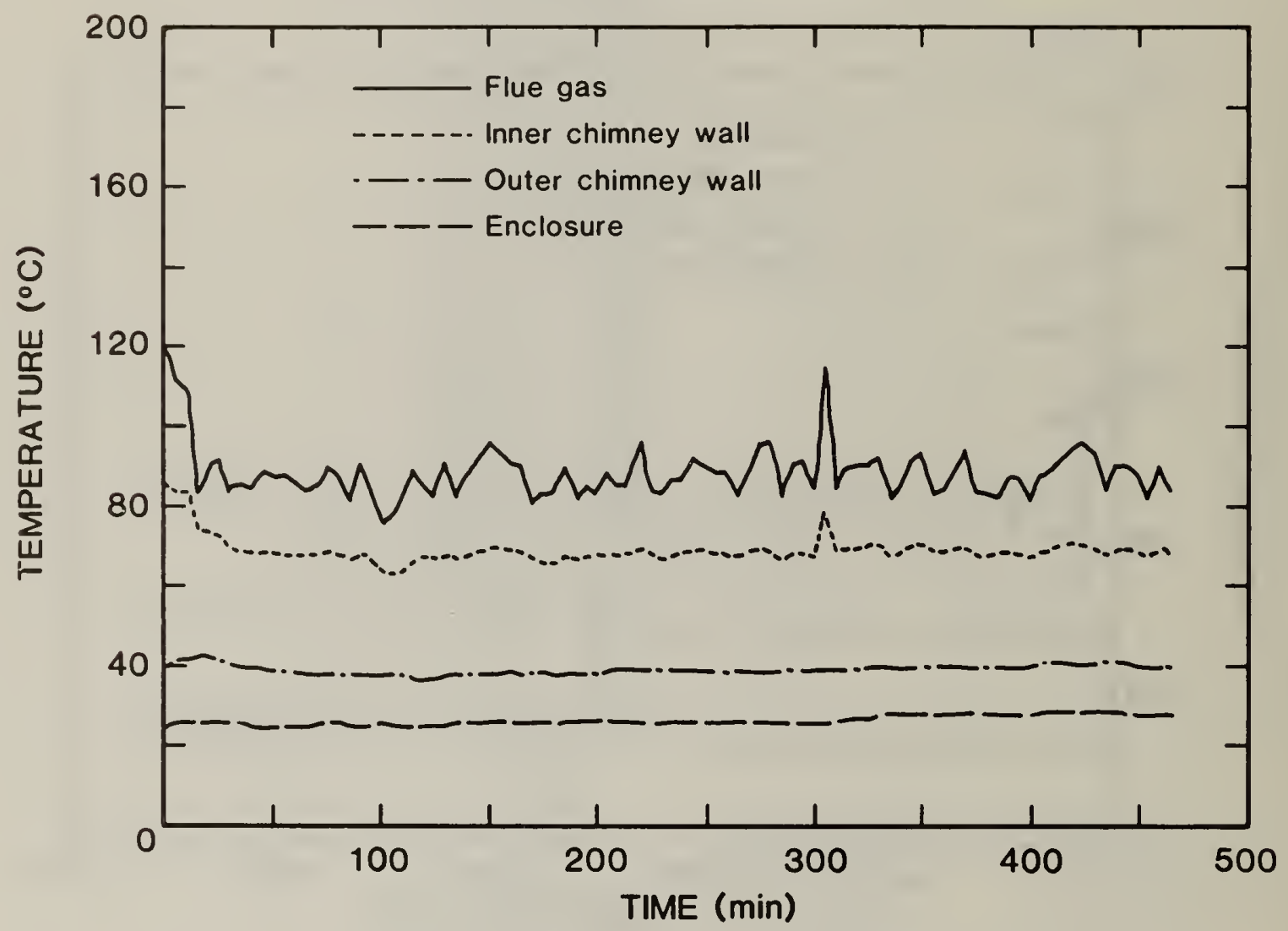

Figure 11. Temperatures at Chimney Base During Creosoting Buildup Test of Chimney 2 . 


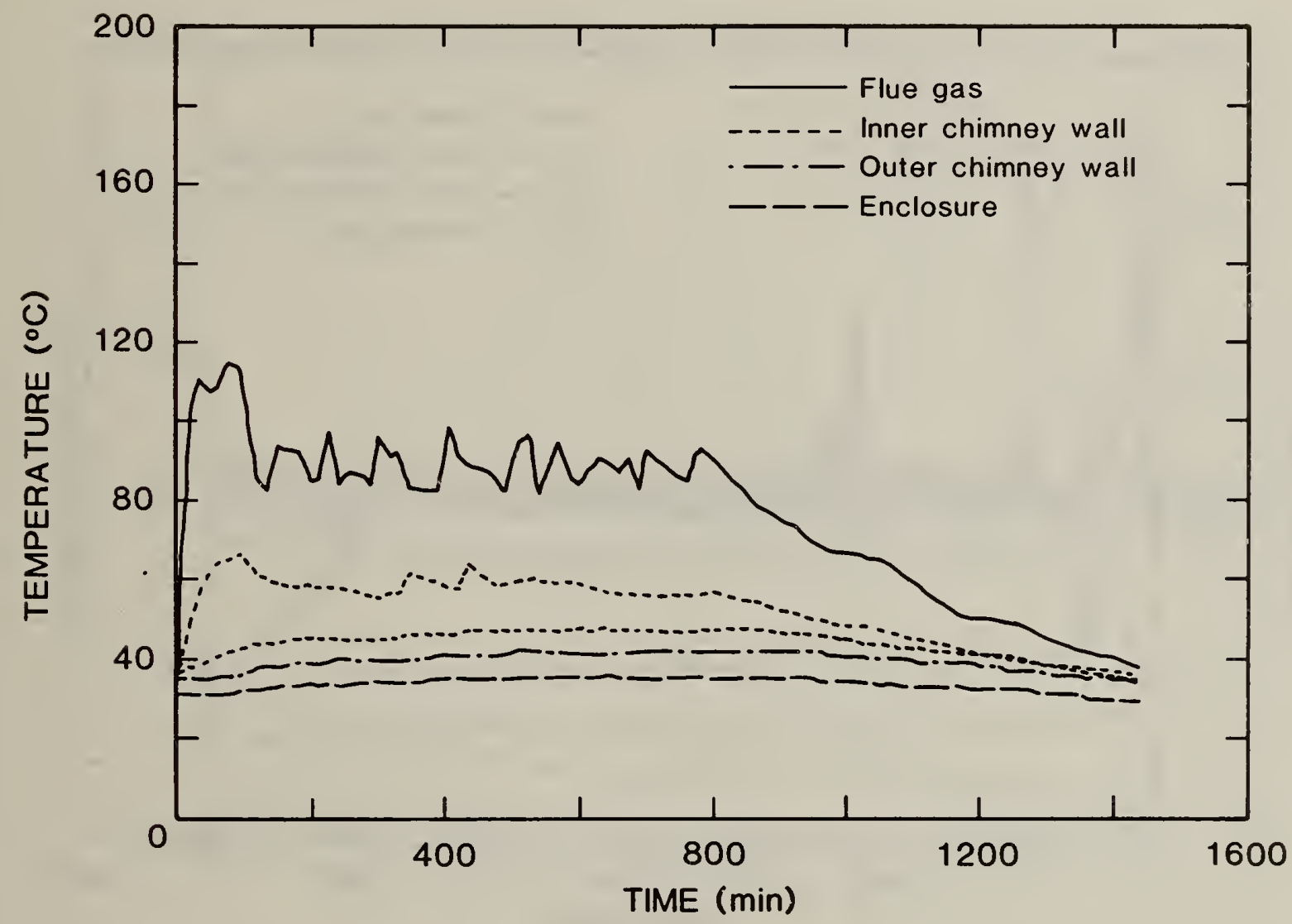

Figure 12. Temperatures at Chimney Base During Creosoting Buildup Test of Chimney 3. 


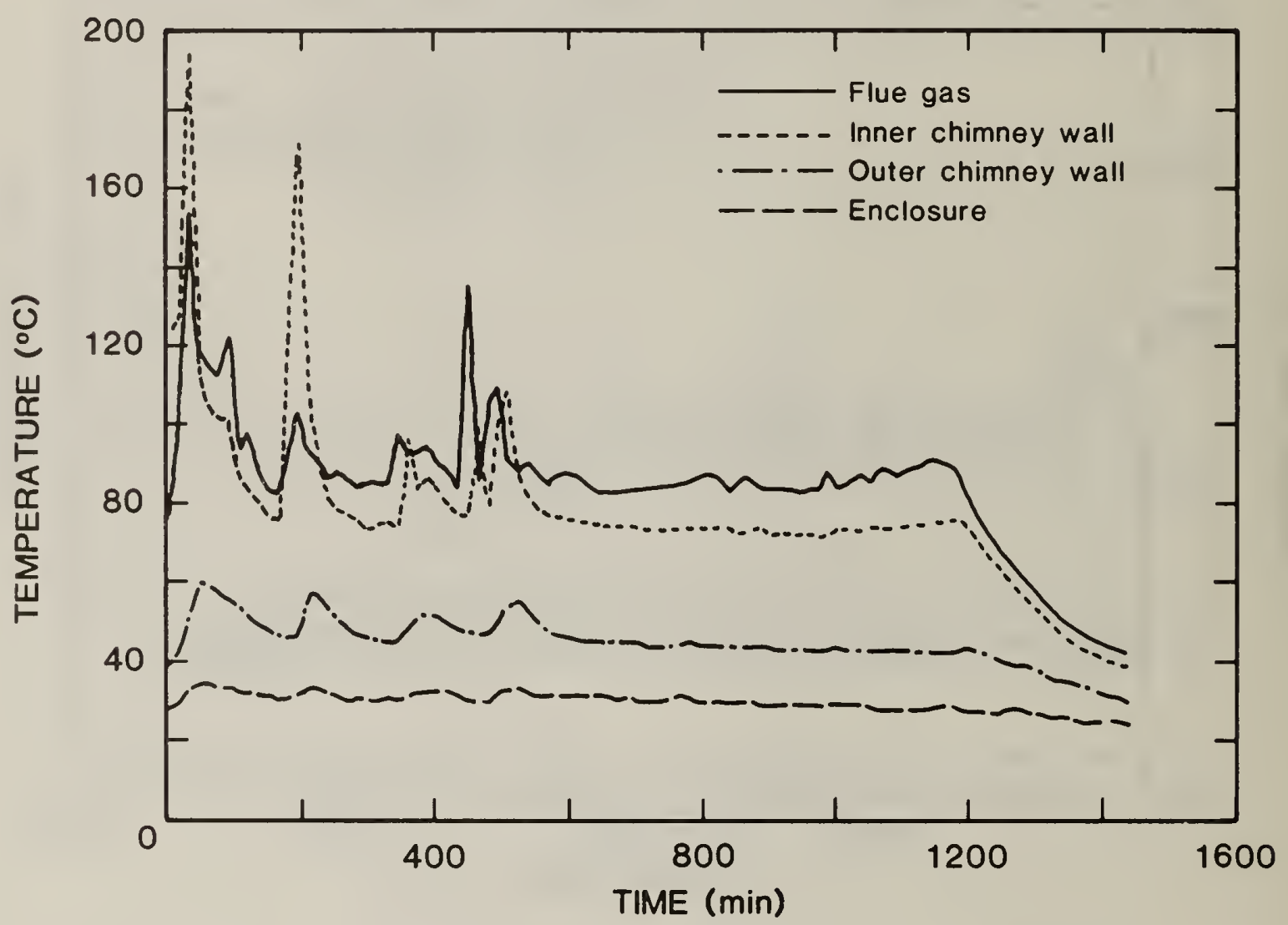

Figure 13. Temperatures at Chimney Base During Creosoting Buildup Test of Chimney 4. 


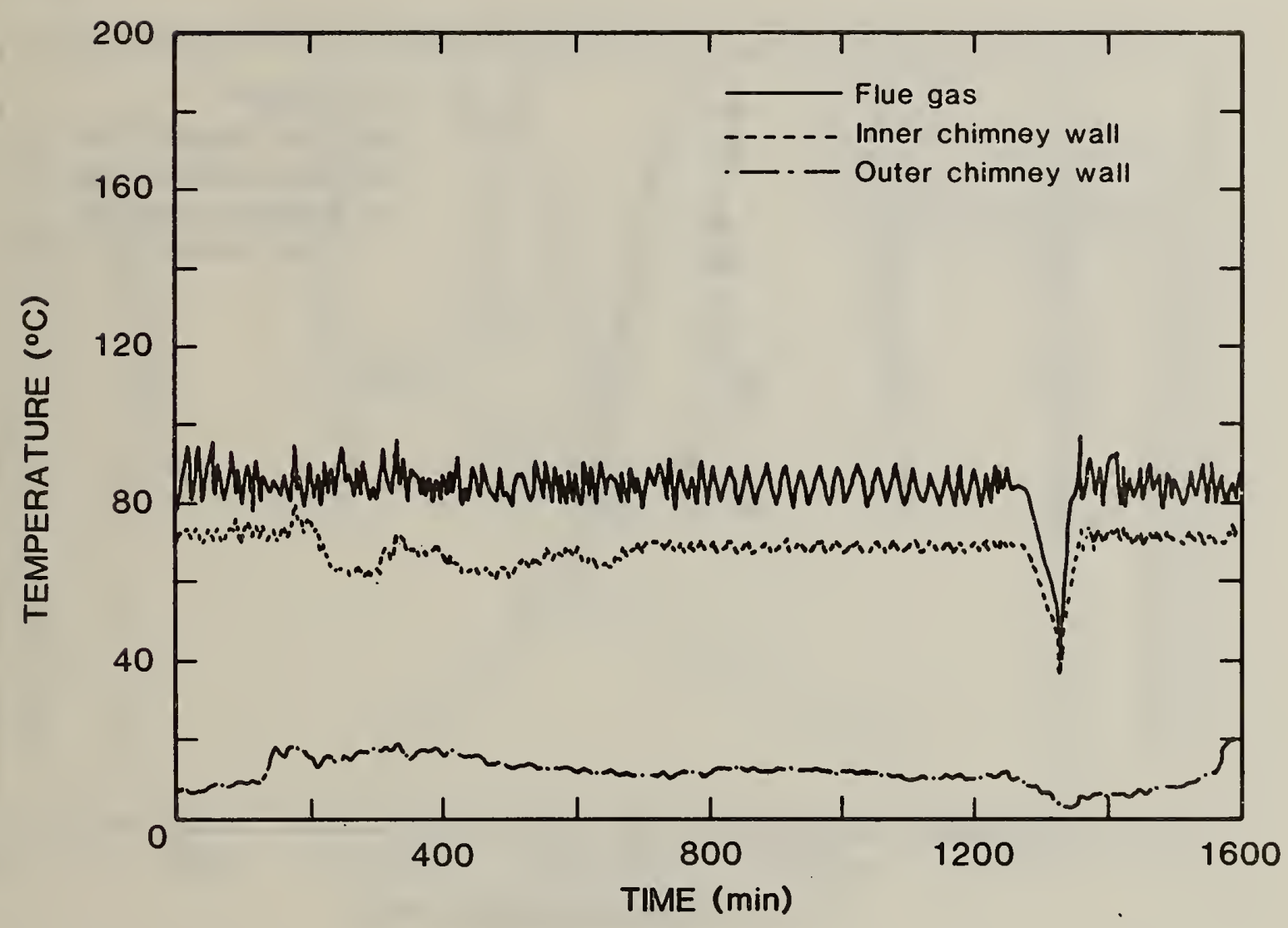

Figure 14. Temperatures at Chimney Base During Creosoting Buildup Test of Chimney 5 . 


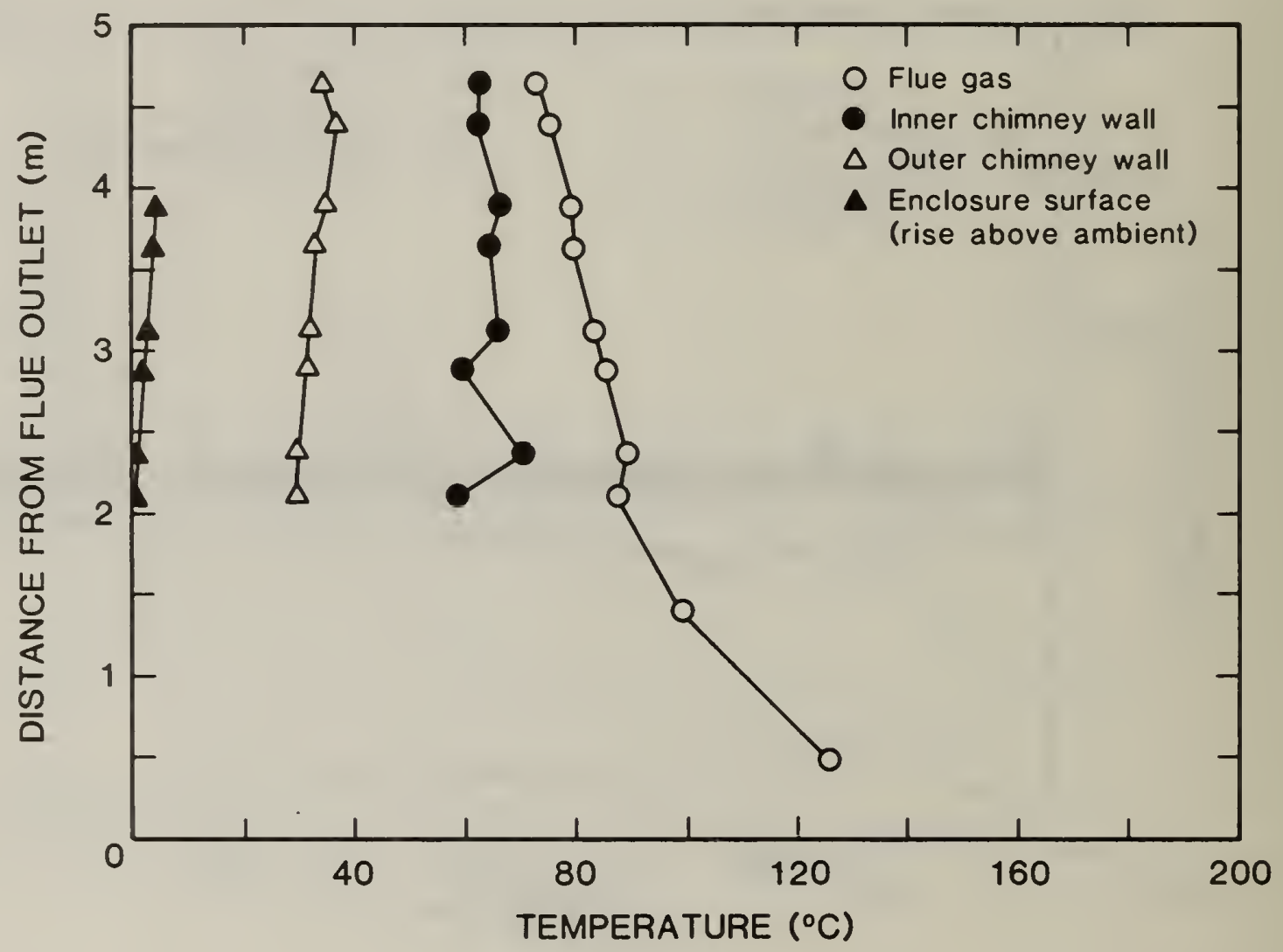

Figure 15. Temperature Profiles During Creosoting Buildup Test of Chimney 1. 


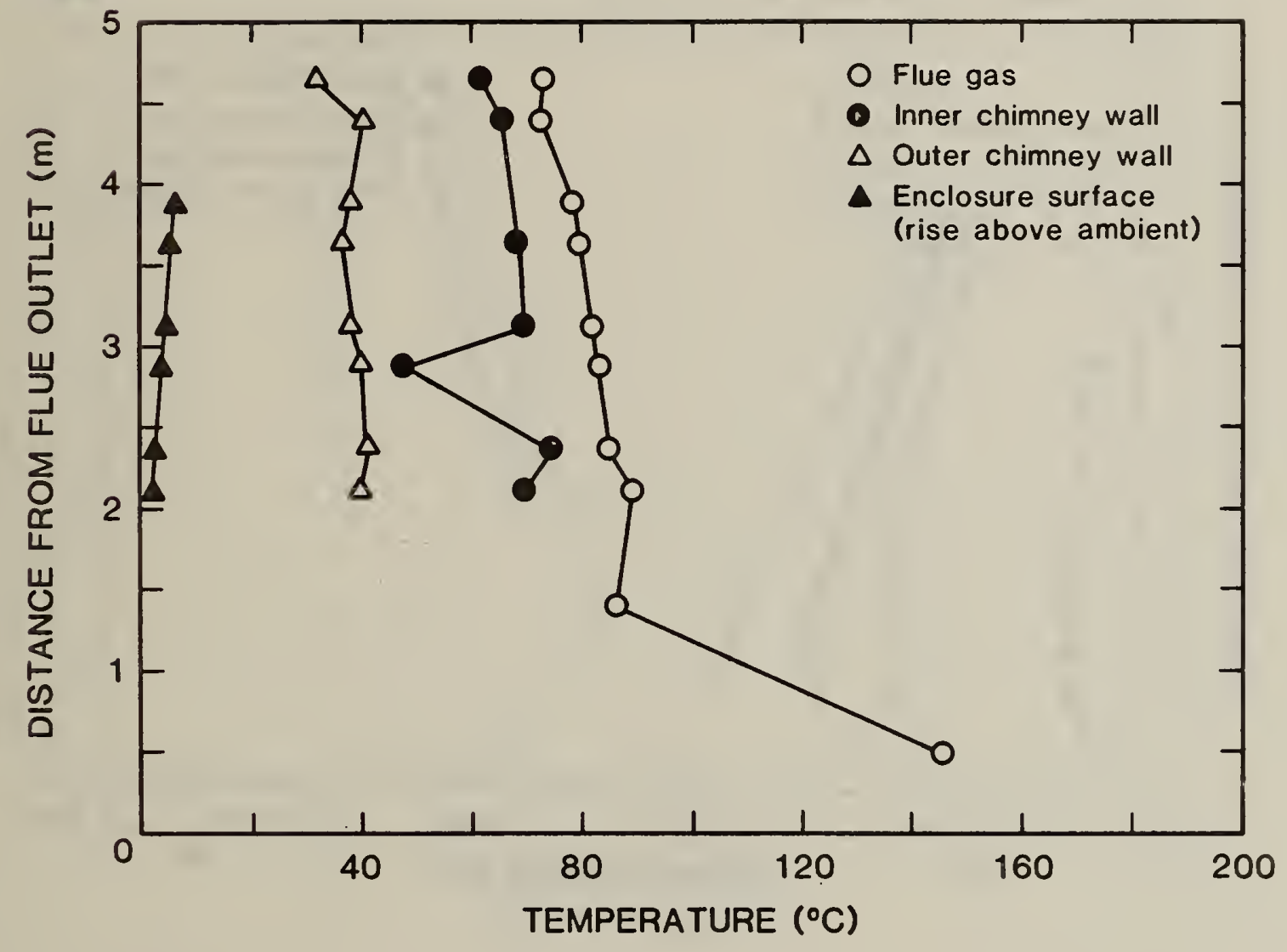

Figure 16. Temperature Profiles During Creosoting Buildup Test of Chimney 2. 


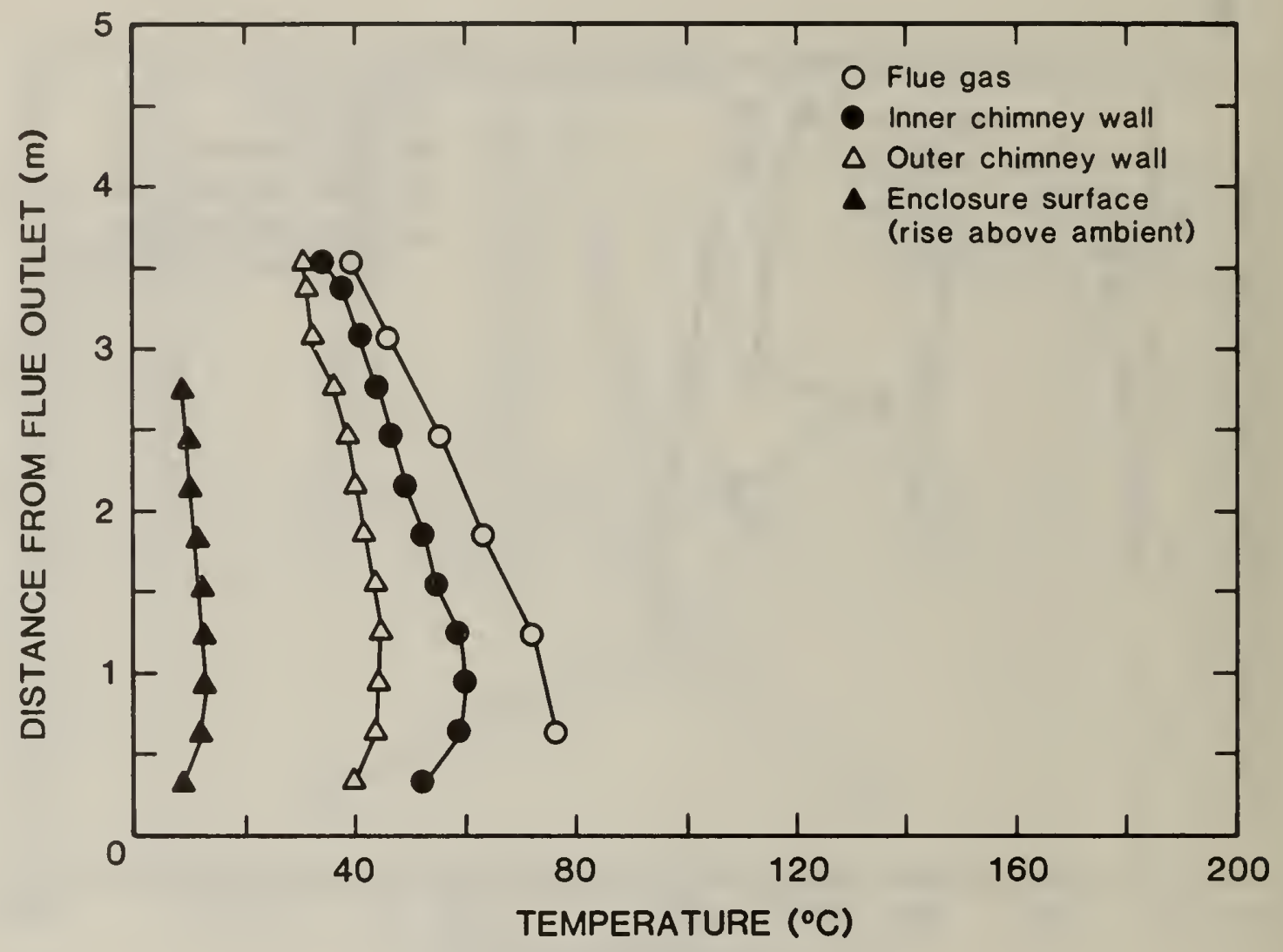

Figure 17. Temperature Profiles During Creosoting Buildup Test of Chimney 3. 


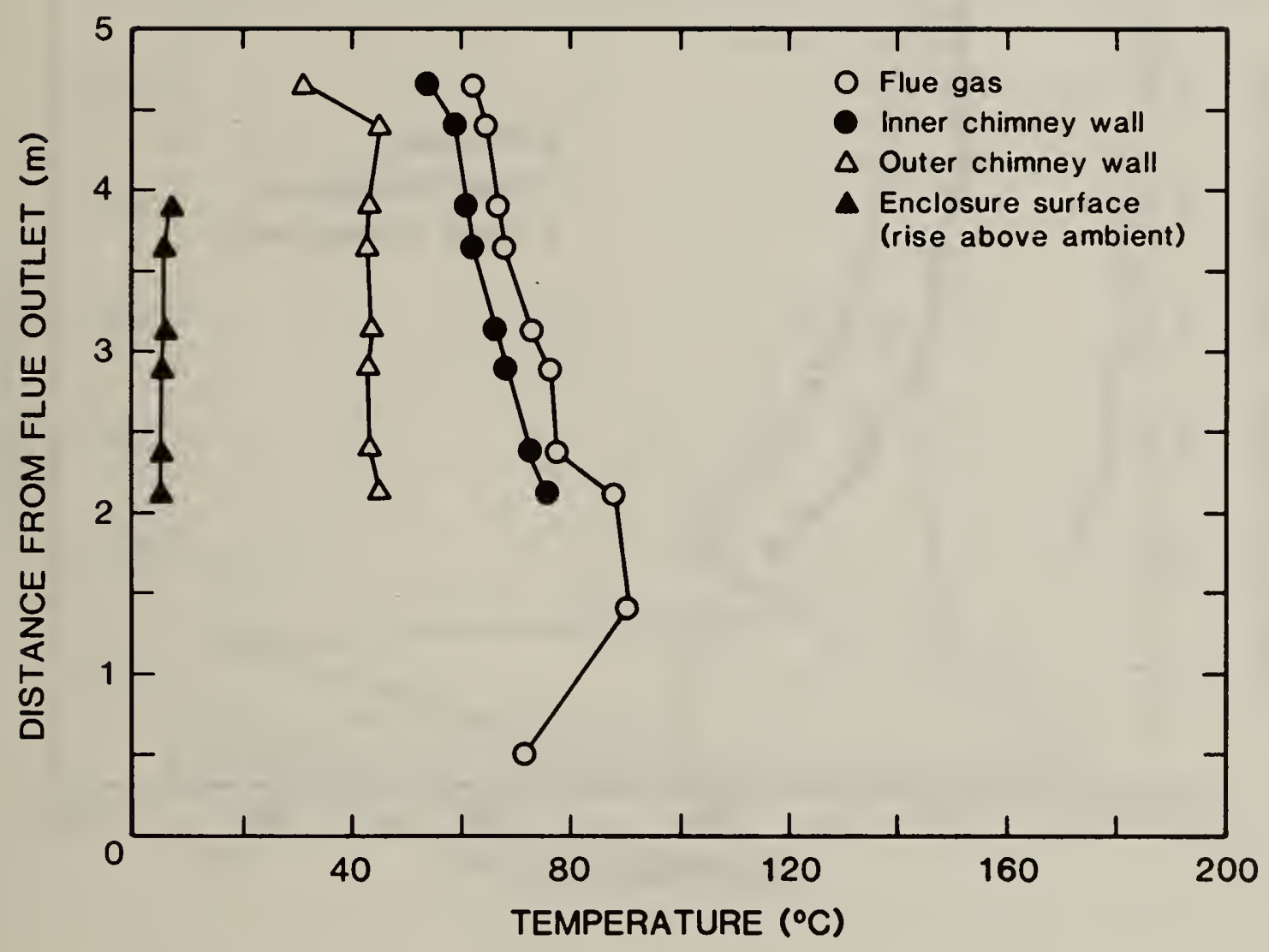

Figure 18. Temperature Profiles During Creosoting Buildup Test of Chimney 4. 


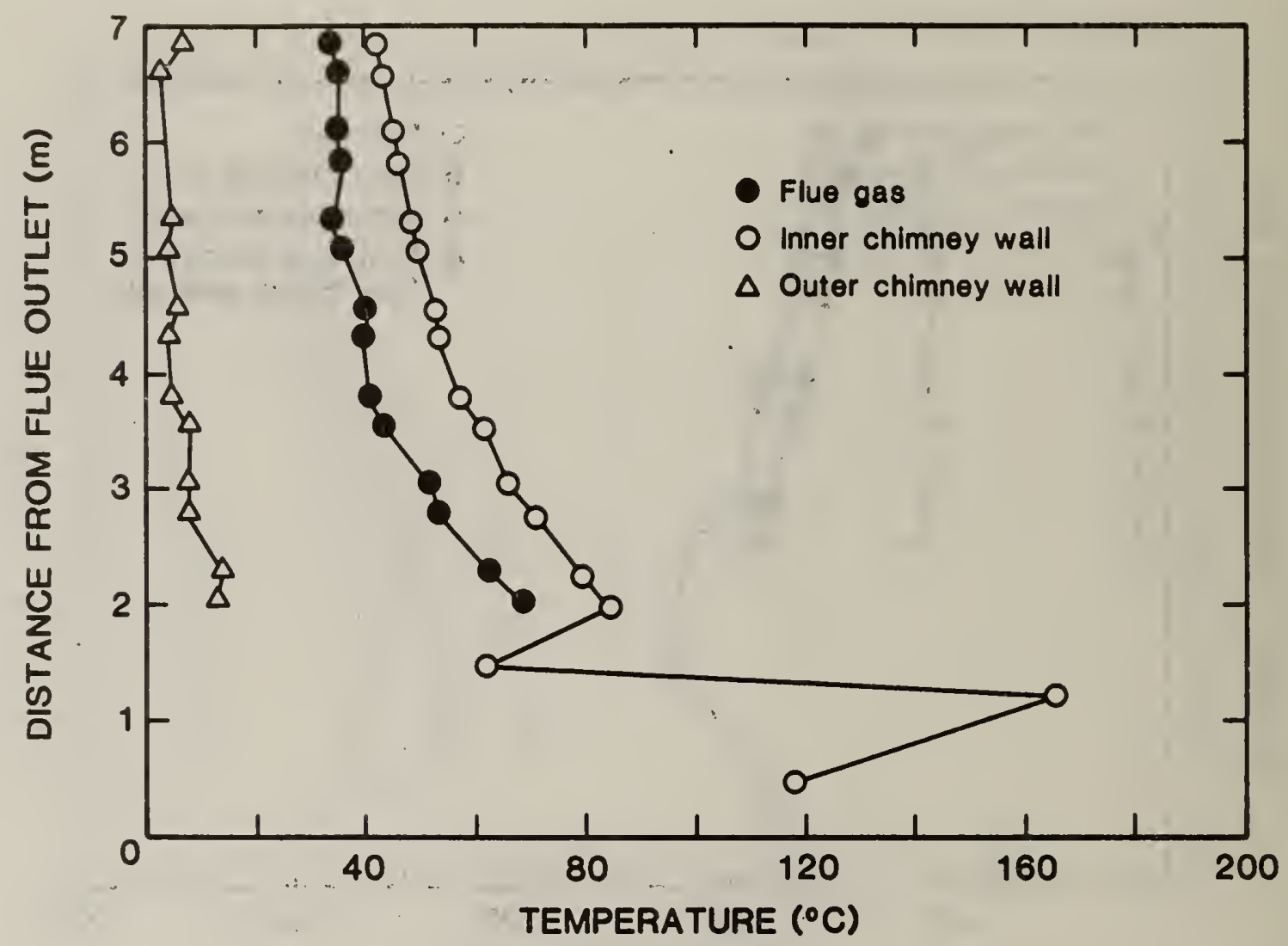

Figure 19. Temperature Profiles During Creosoting Bulldup Test of Chimney 5. 


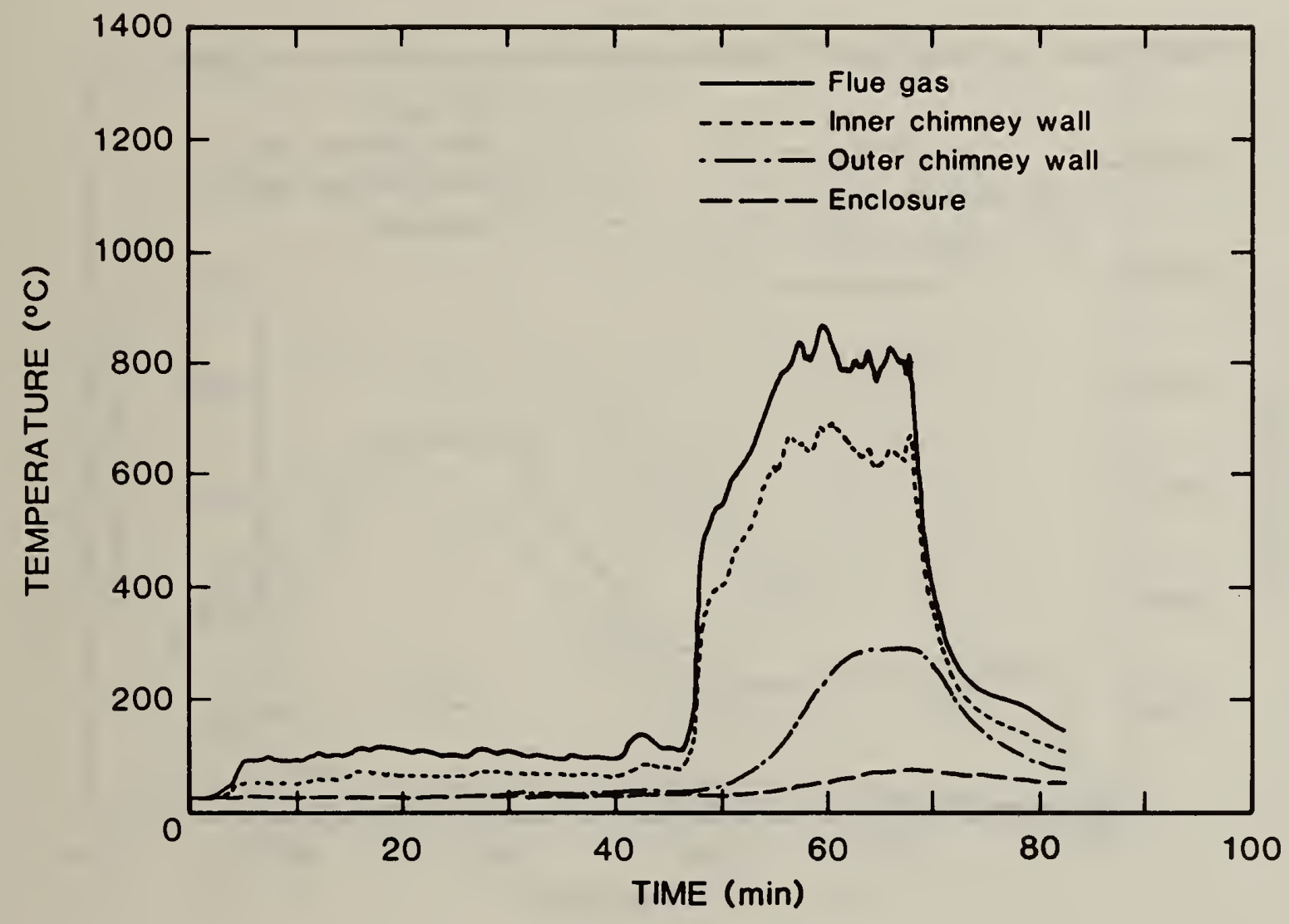

Figure 20. Temperatures at Chimney Base During Burnout of Chimney 1, Test 1. 


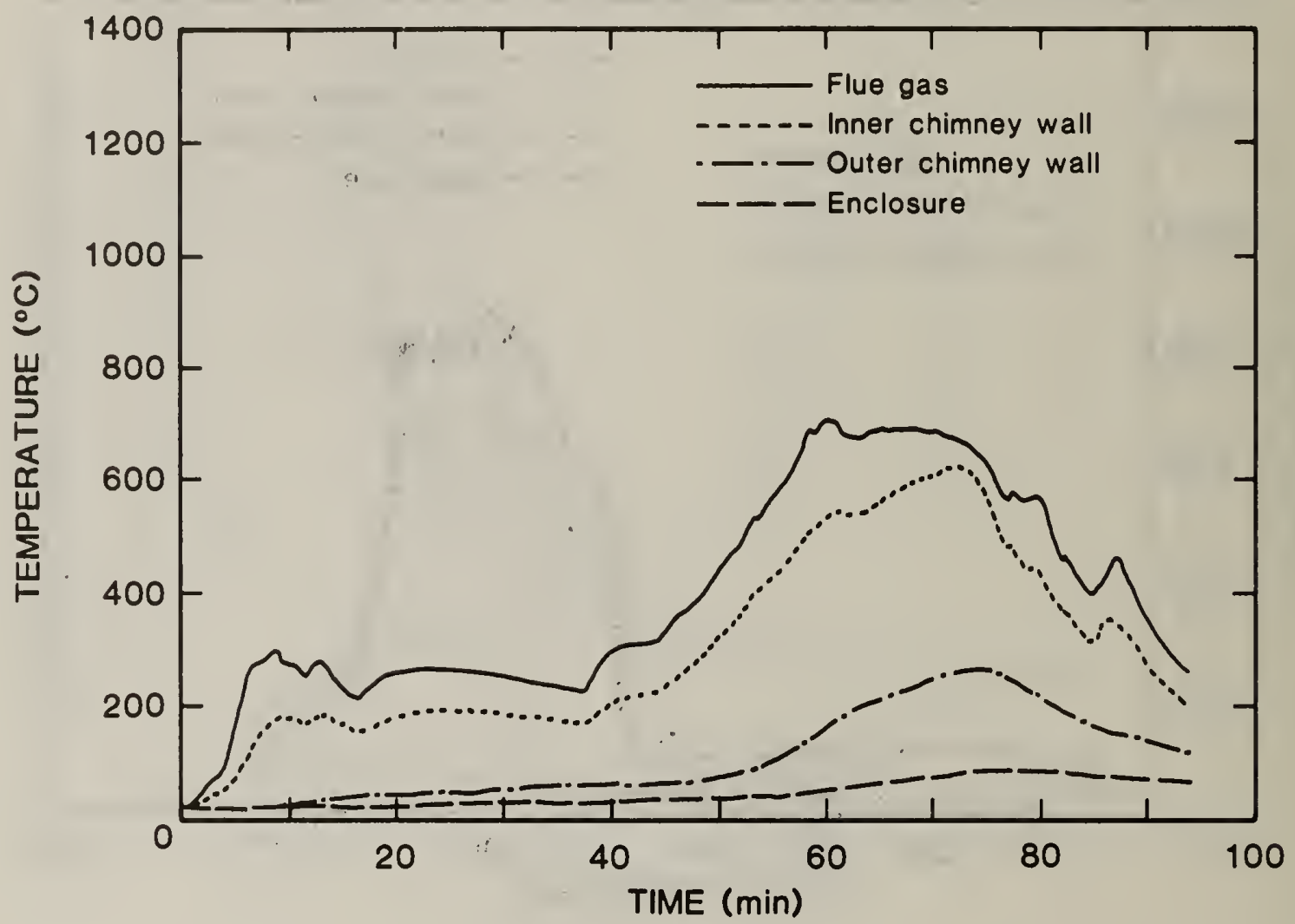

Figure 21. Temperatures at Chimney Base During Burnout of Chimney 1, Test 2. 


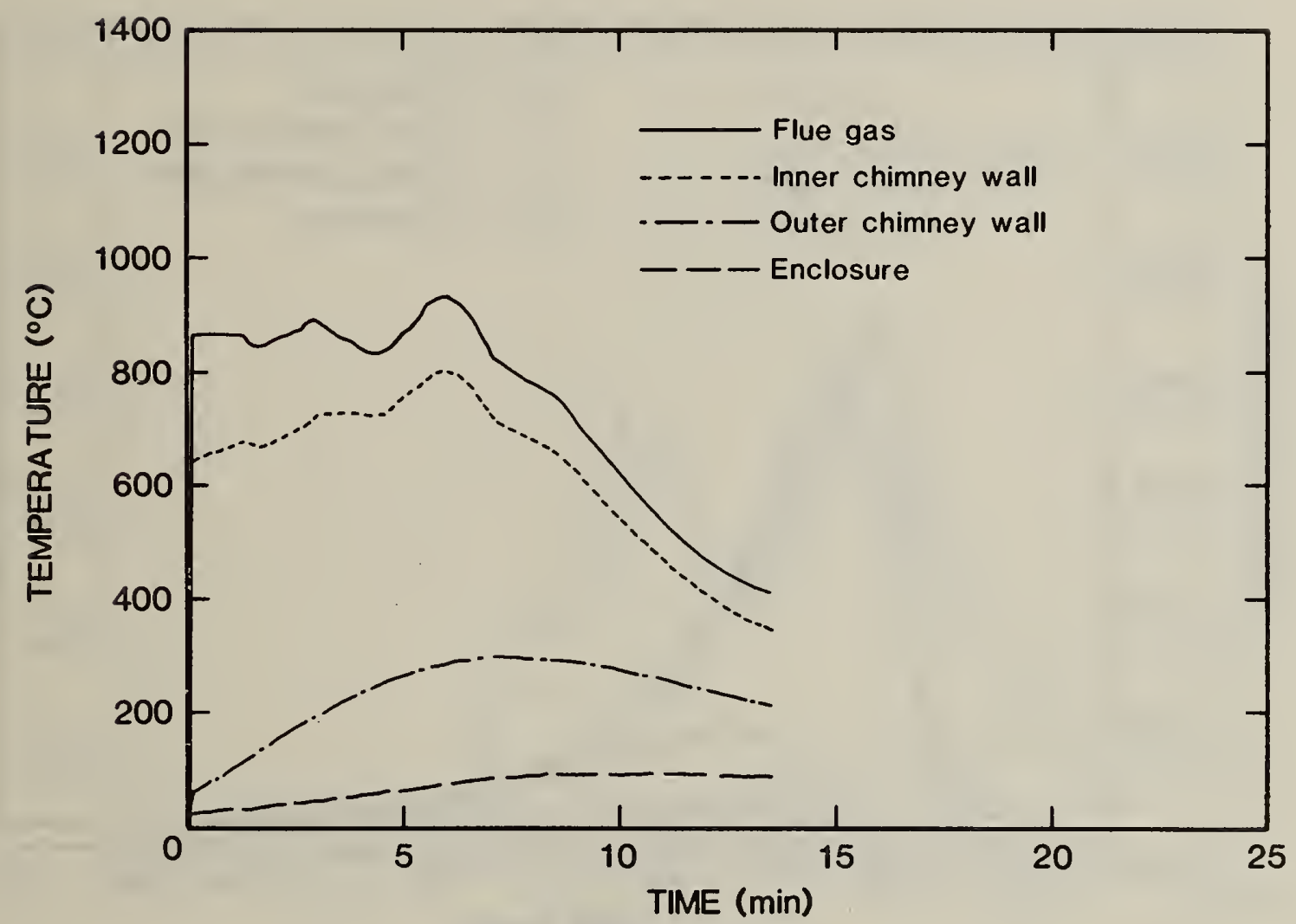

Figure 22. Temperatures at Chimney Base During Burnout of Chimney 1, Test 3 . 


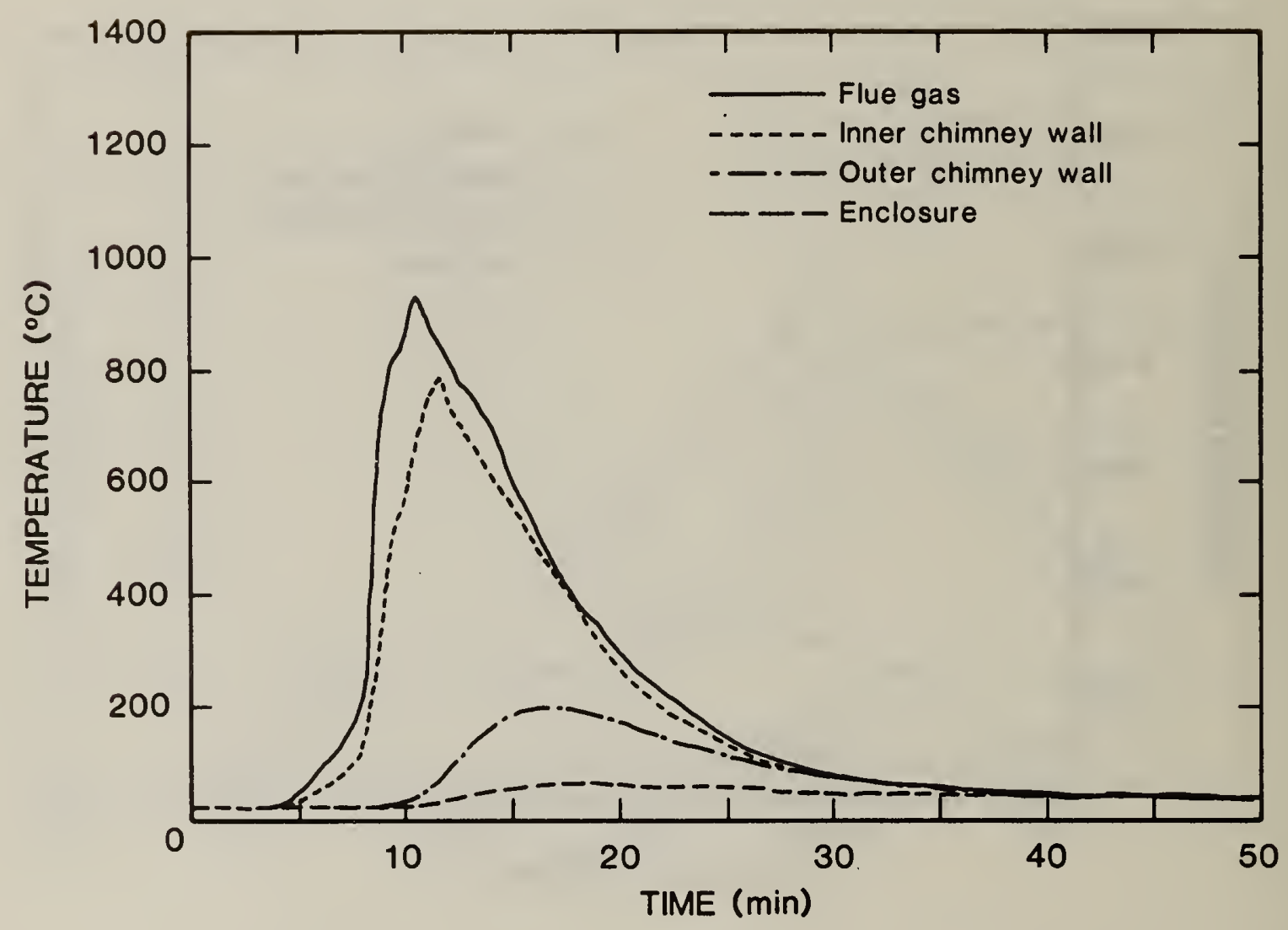

Figure 23. Temperatures at Chimney Base During Burnout of Chimney 1, Test 


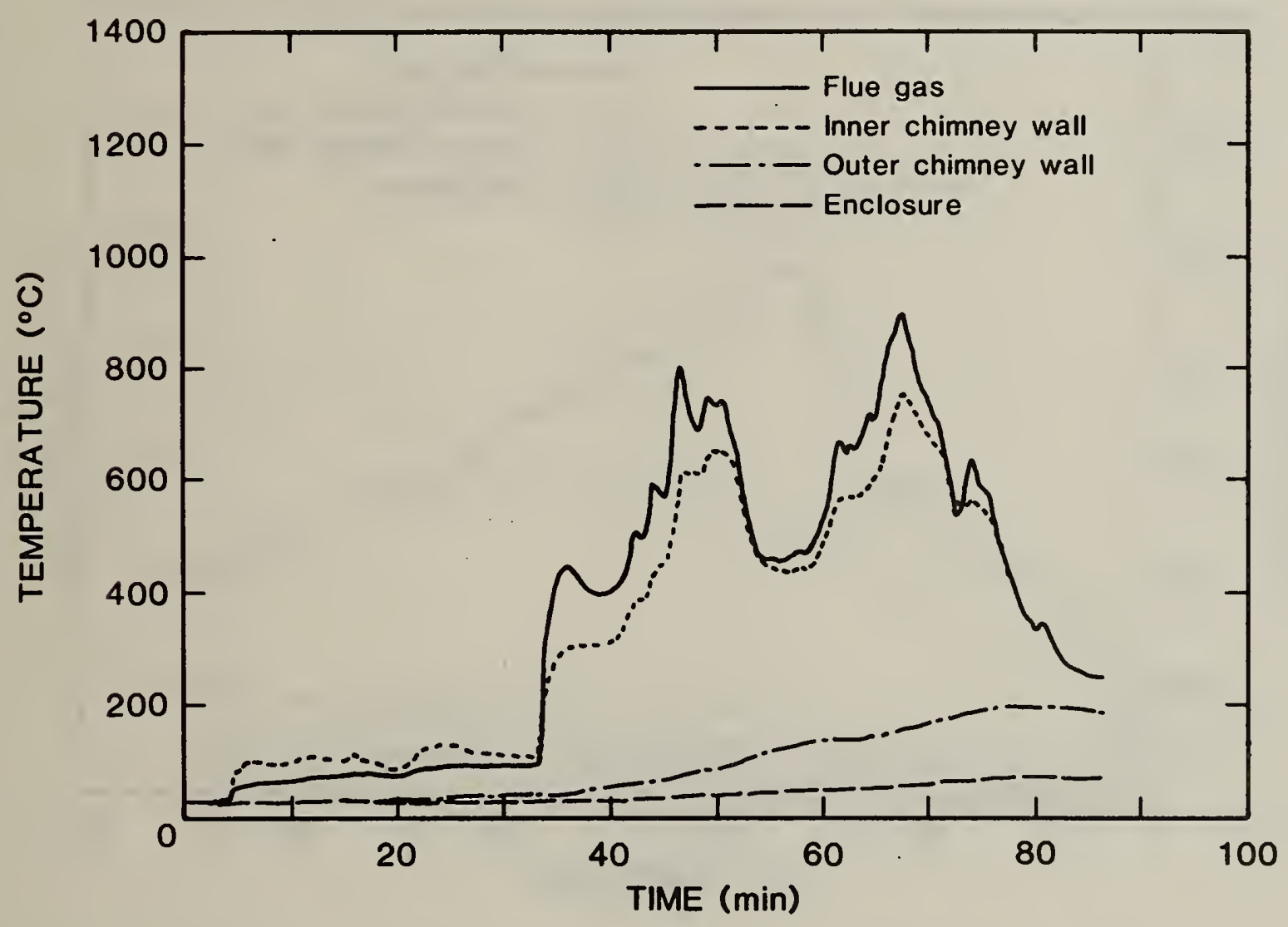

Figure 24. Temperatures at Chimney Base During Burnout of Chimney 2, Test 5. 


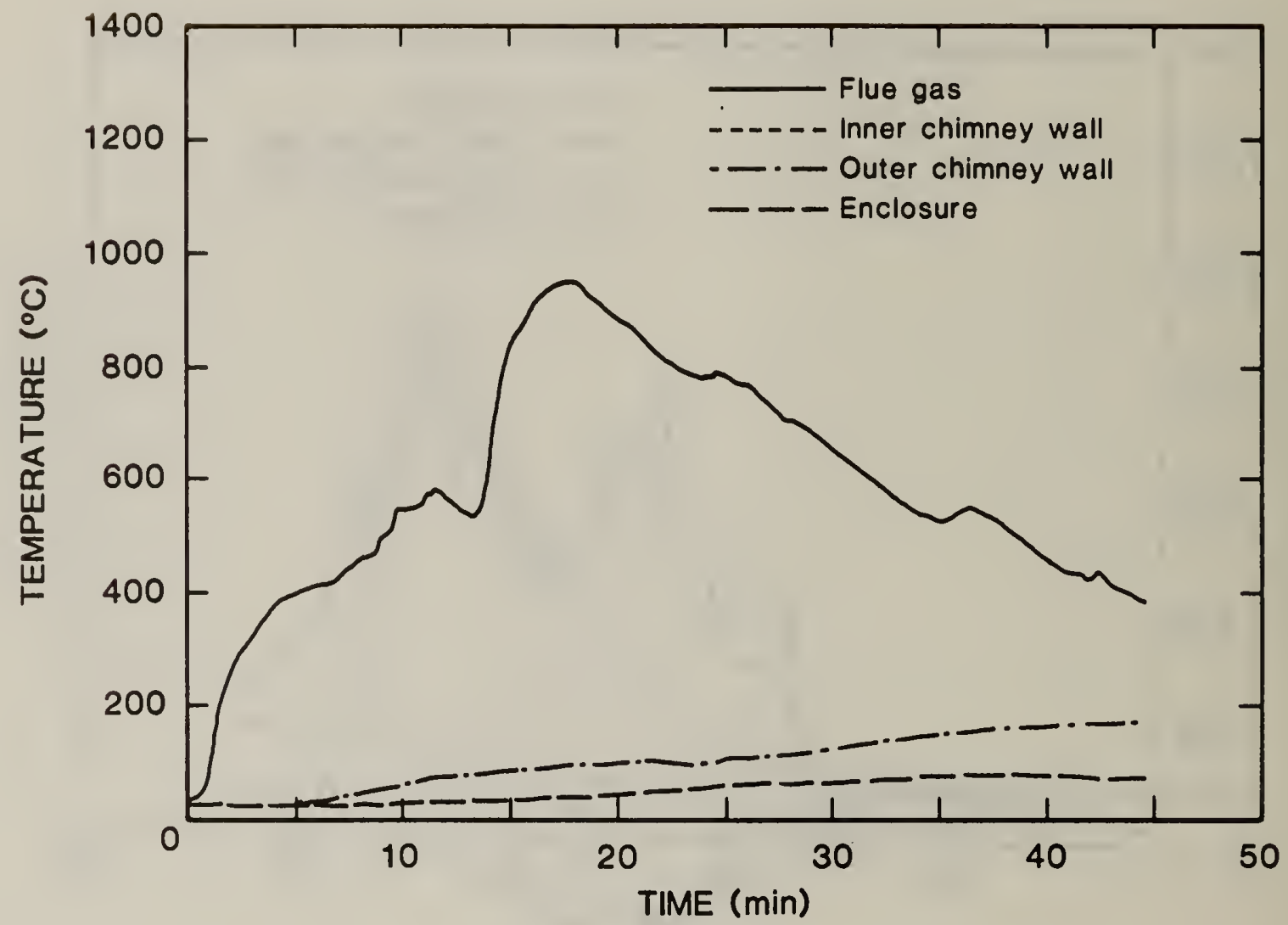

Figure 25. Temperatures at Chimney Base During Burnout of Chimney 2, Test 6. 


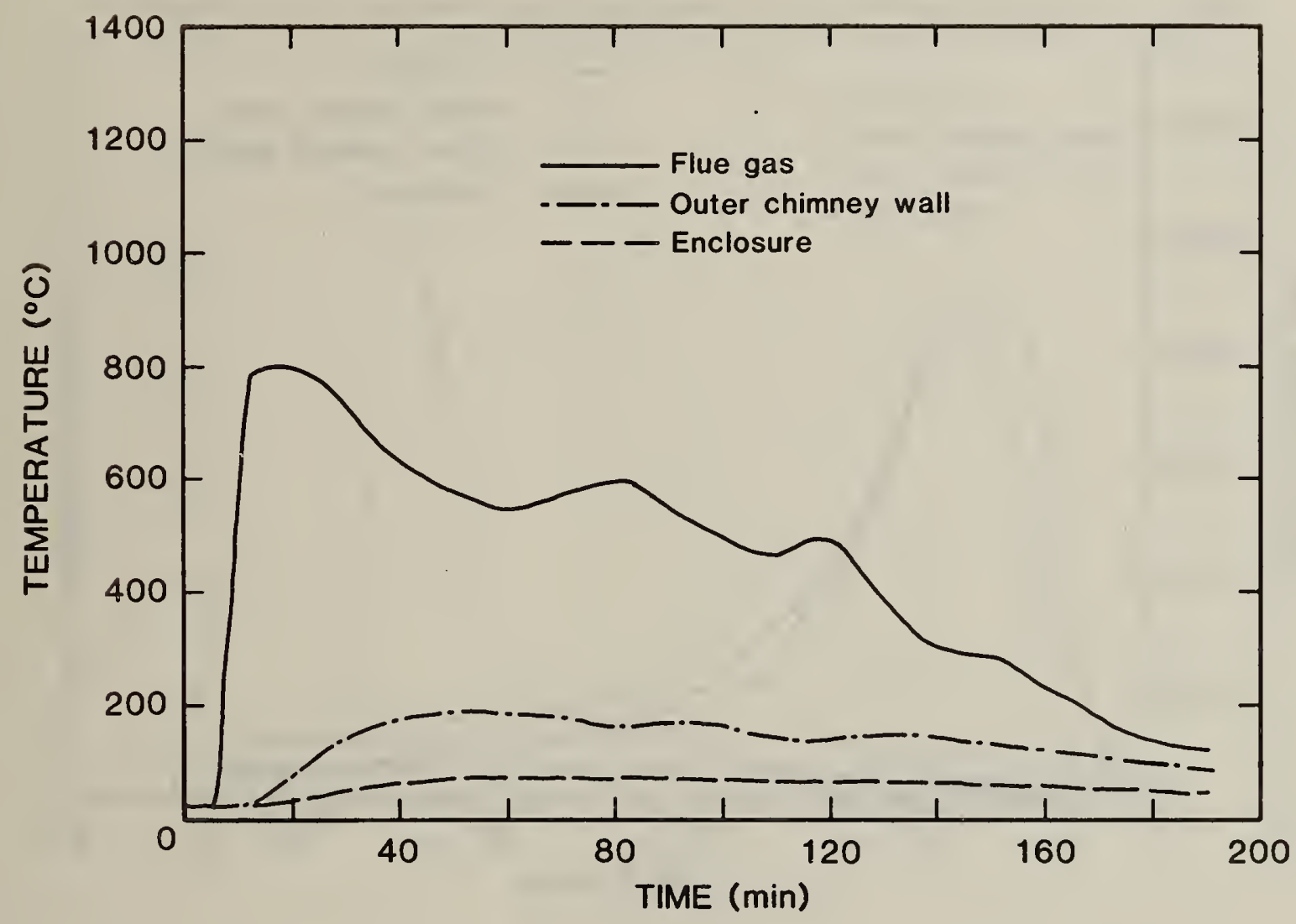

Figure 26. Temperatures at Chimney Base During Burnout of Chimney 2, Test 7. 


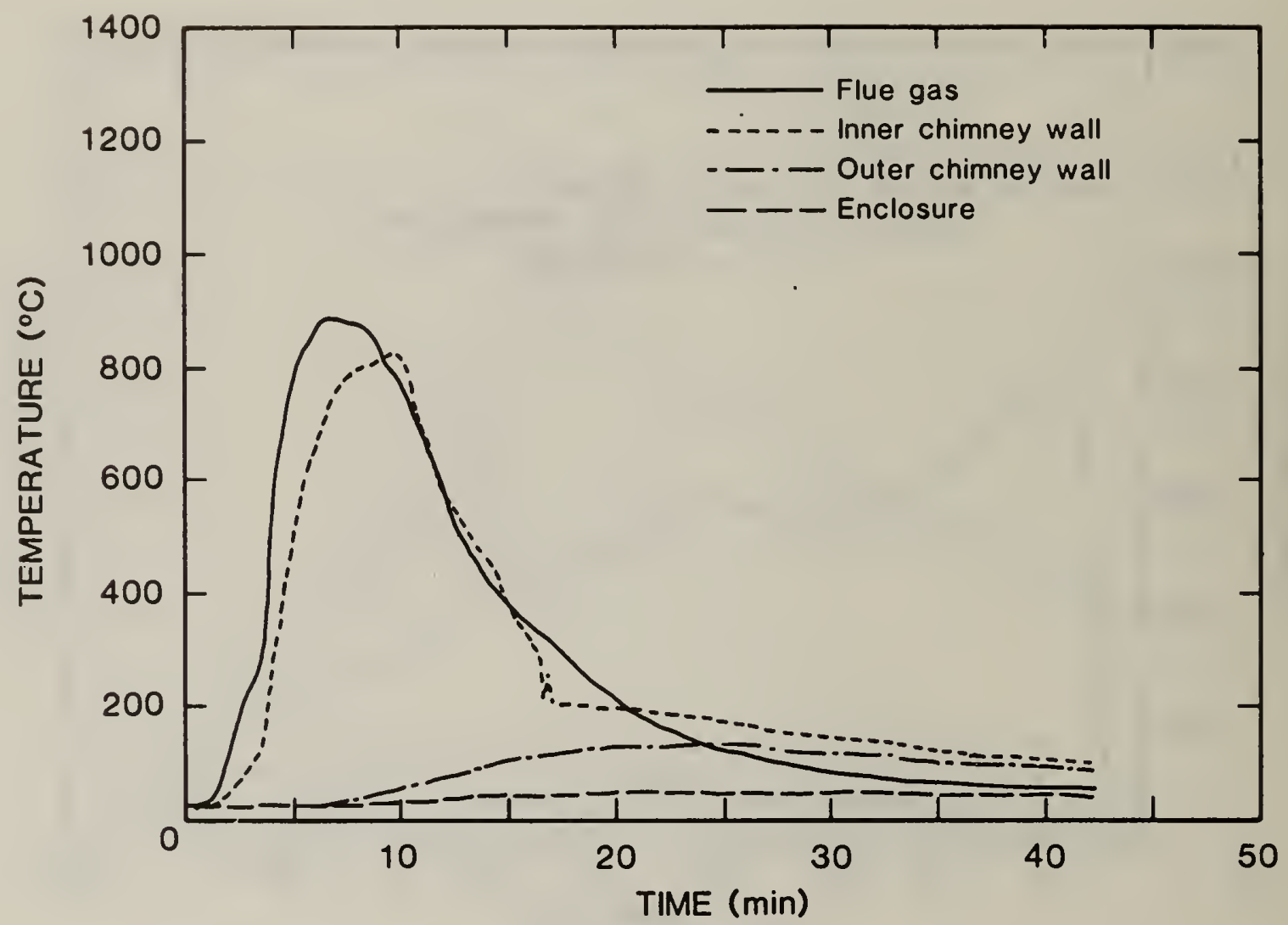

Figure 27. Temperatures at Chimney Base During Burnout of Chimney 2, Test 8. 


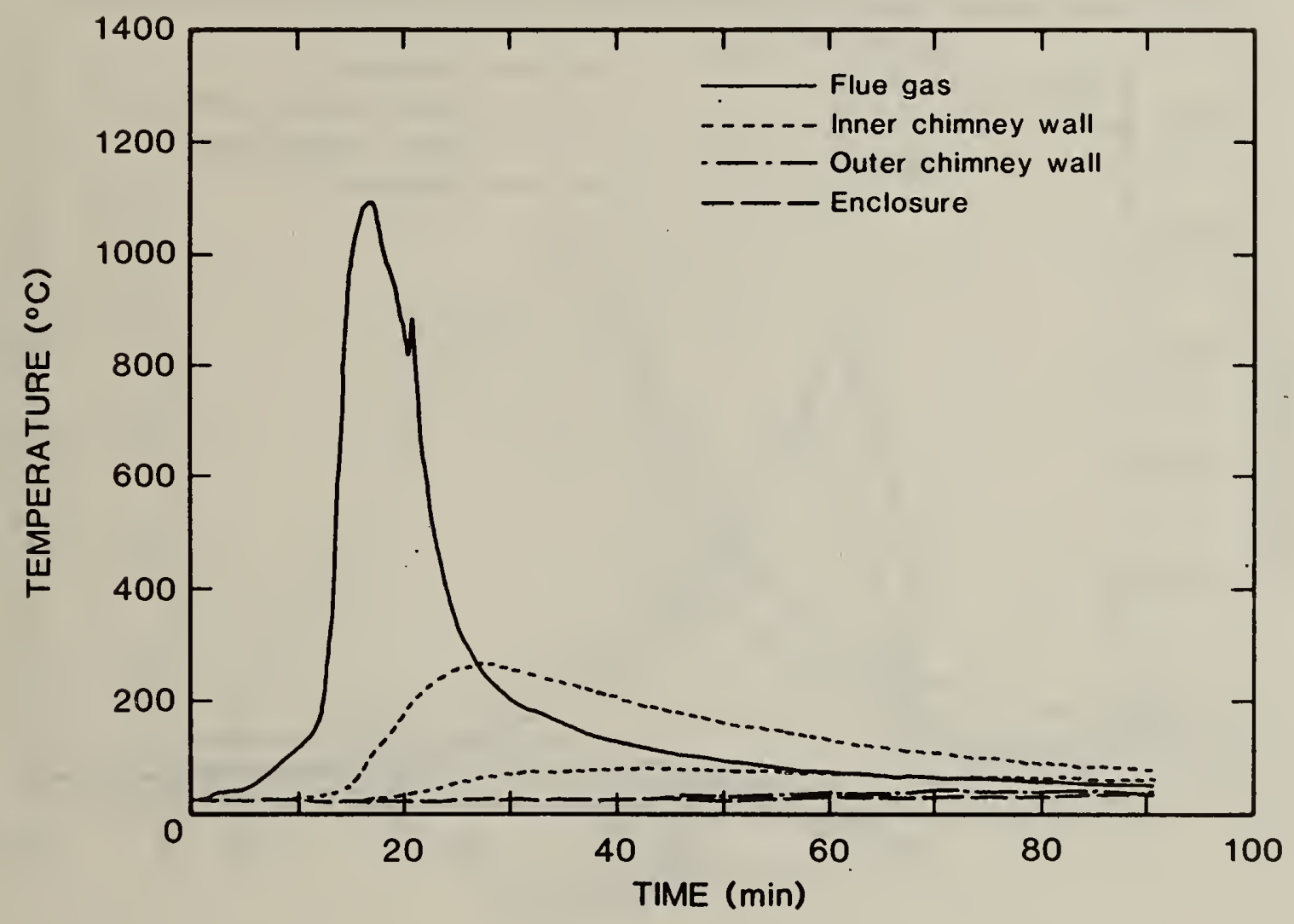

Figure 28. Temperatures at Chimney Base During Burnout of Chimney 3, Test 9. 


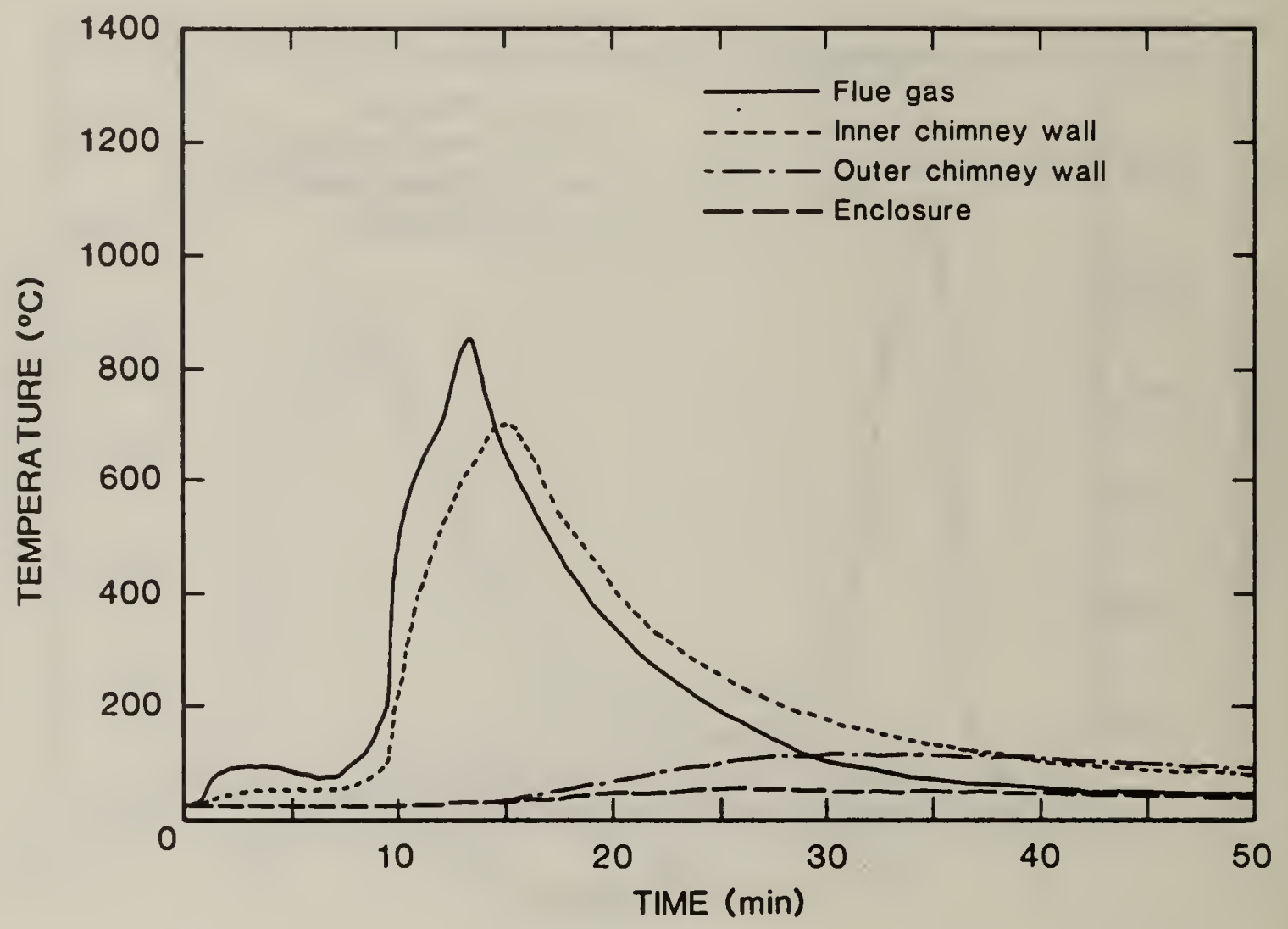

F1gure 29. Temperatures at Chimney Base During Burnout of Chimney 4, Test 10. 


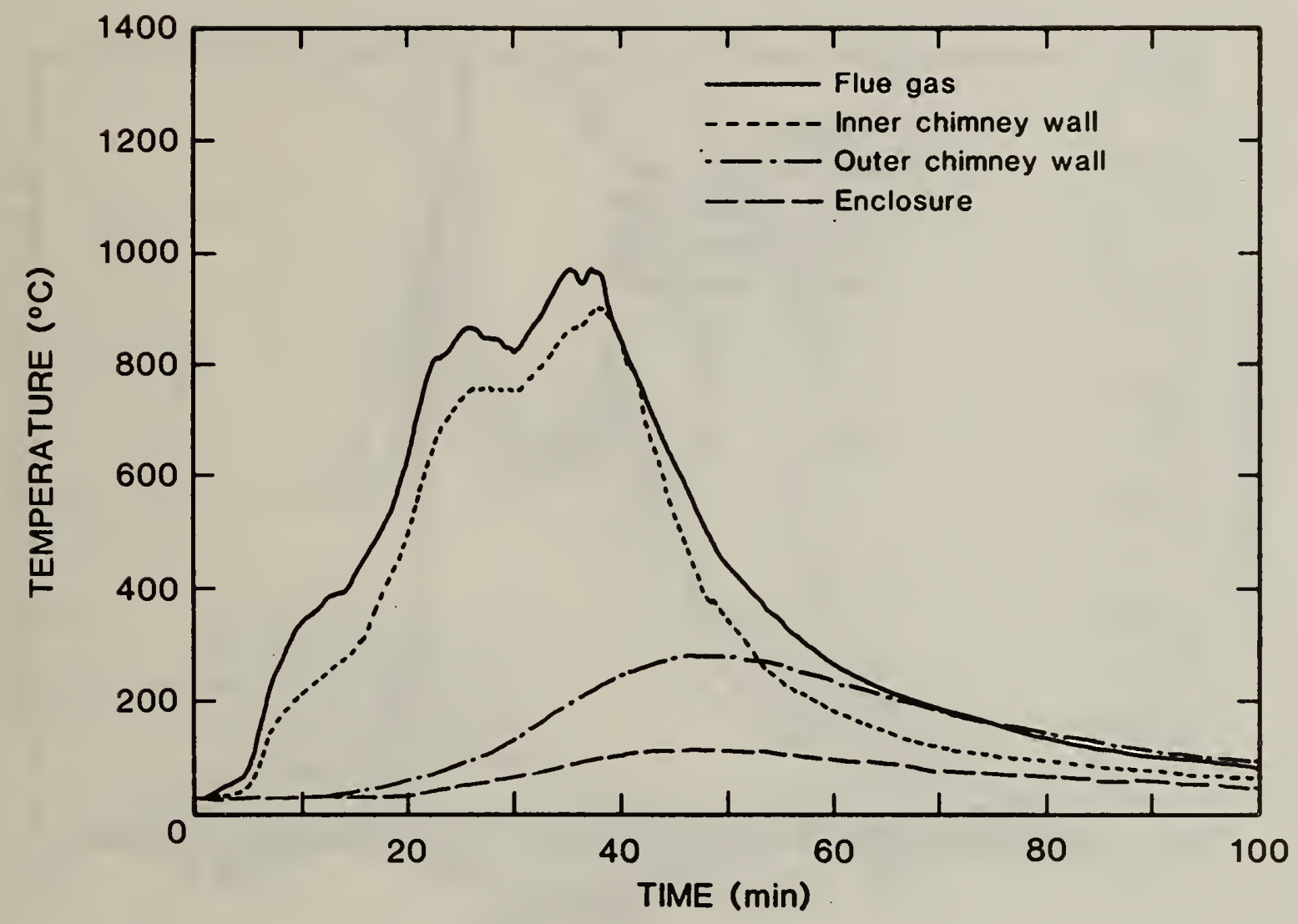

Figure 30. Temperatures at Chimney Base During Burnout of Chimney 4, Test 11. 


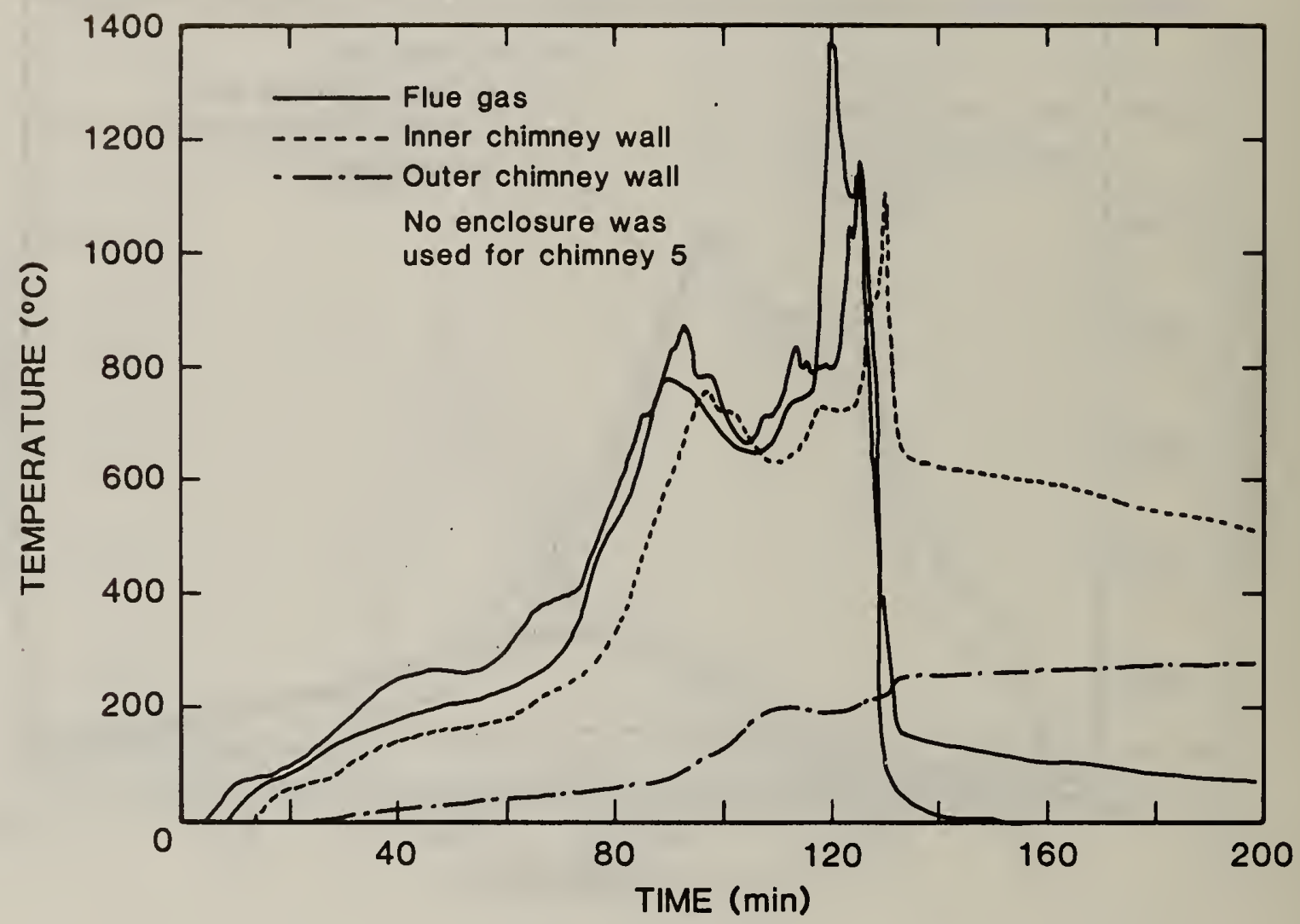

F1gure 31. Temperatures at Ch1mney Base During Burnout of Ch1mney.5, Test 12. 


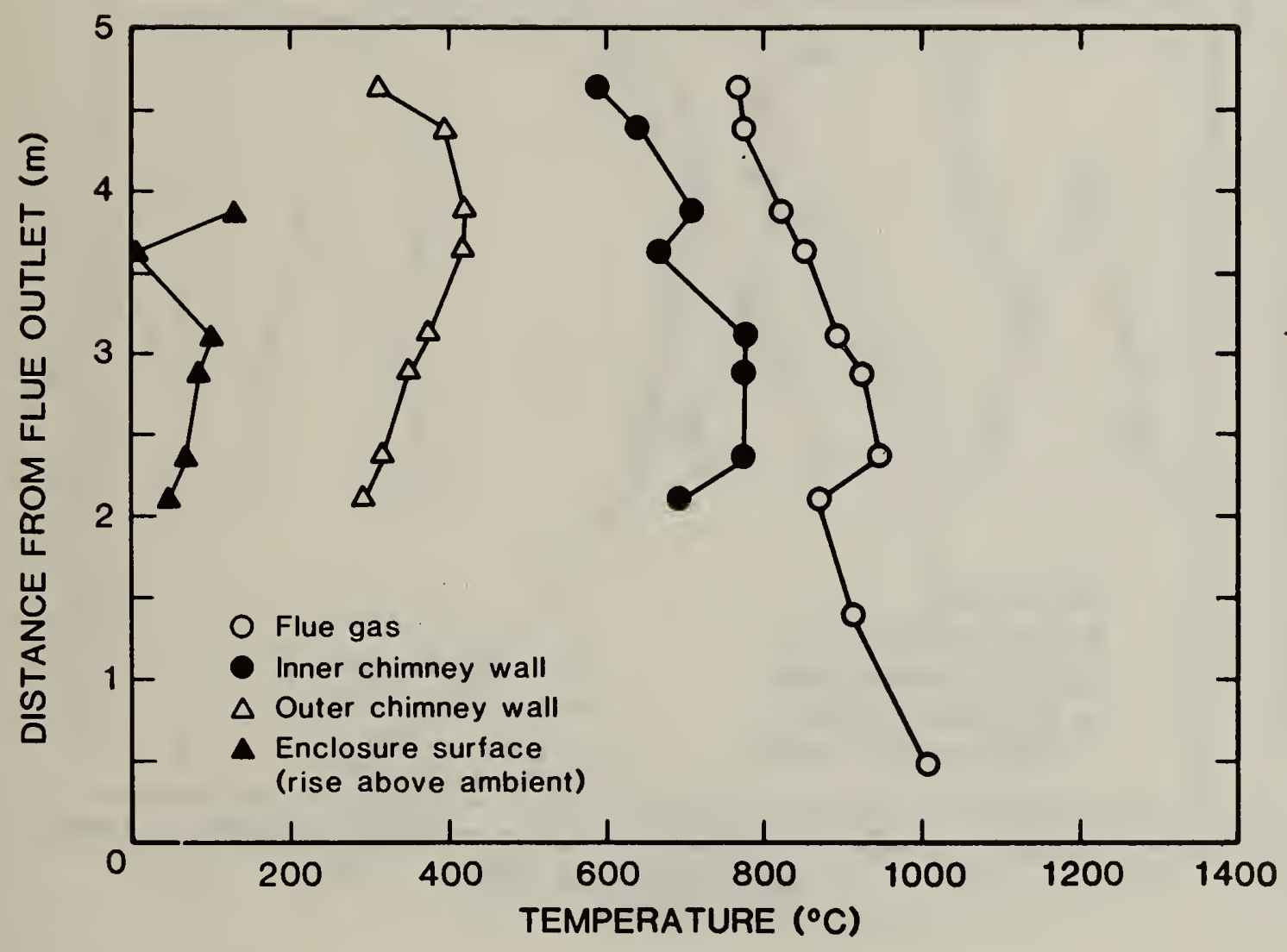

Figure 32. Temperature Profiles During Burnout Test of Chimney 1, Test 1. 


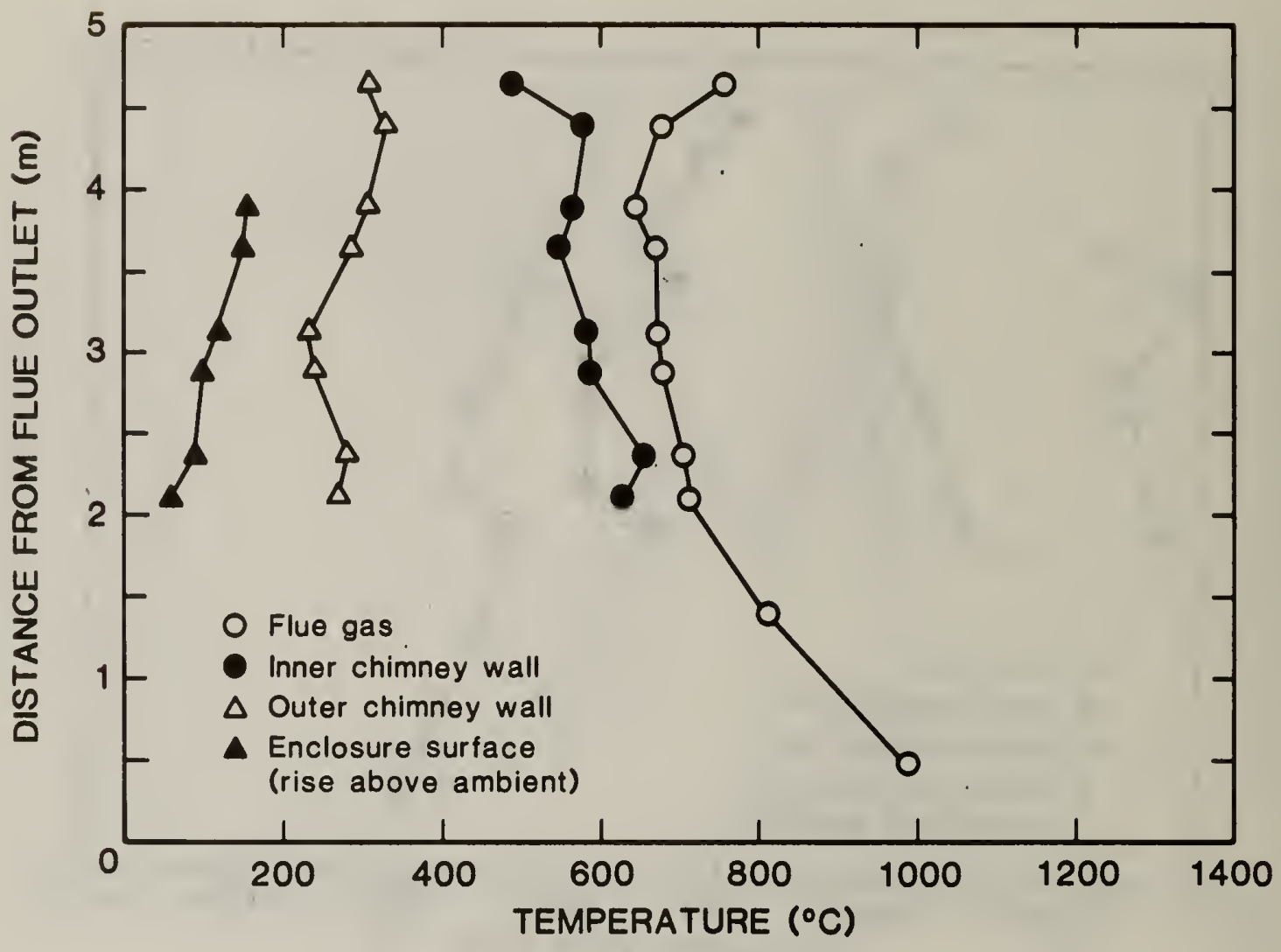

F1gure 33. Temperature Profiles During Burnout Test of Ch1mney 1, Test. 2. 


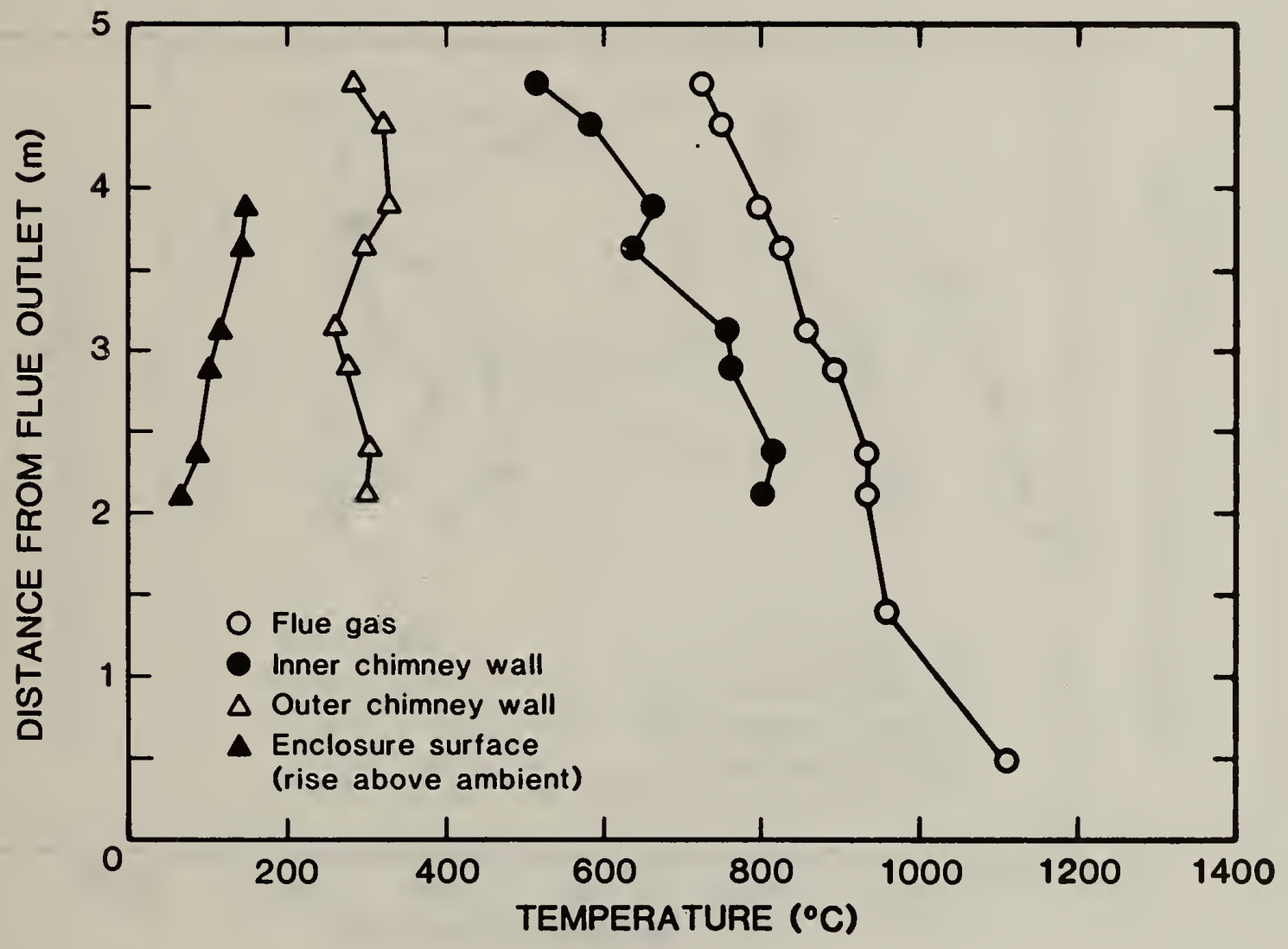

Figure 34. Temperature Profiles During Burnout Test of Chimney 1, Test 3. 


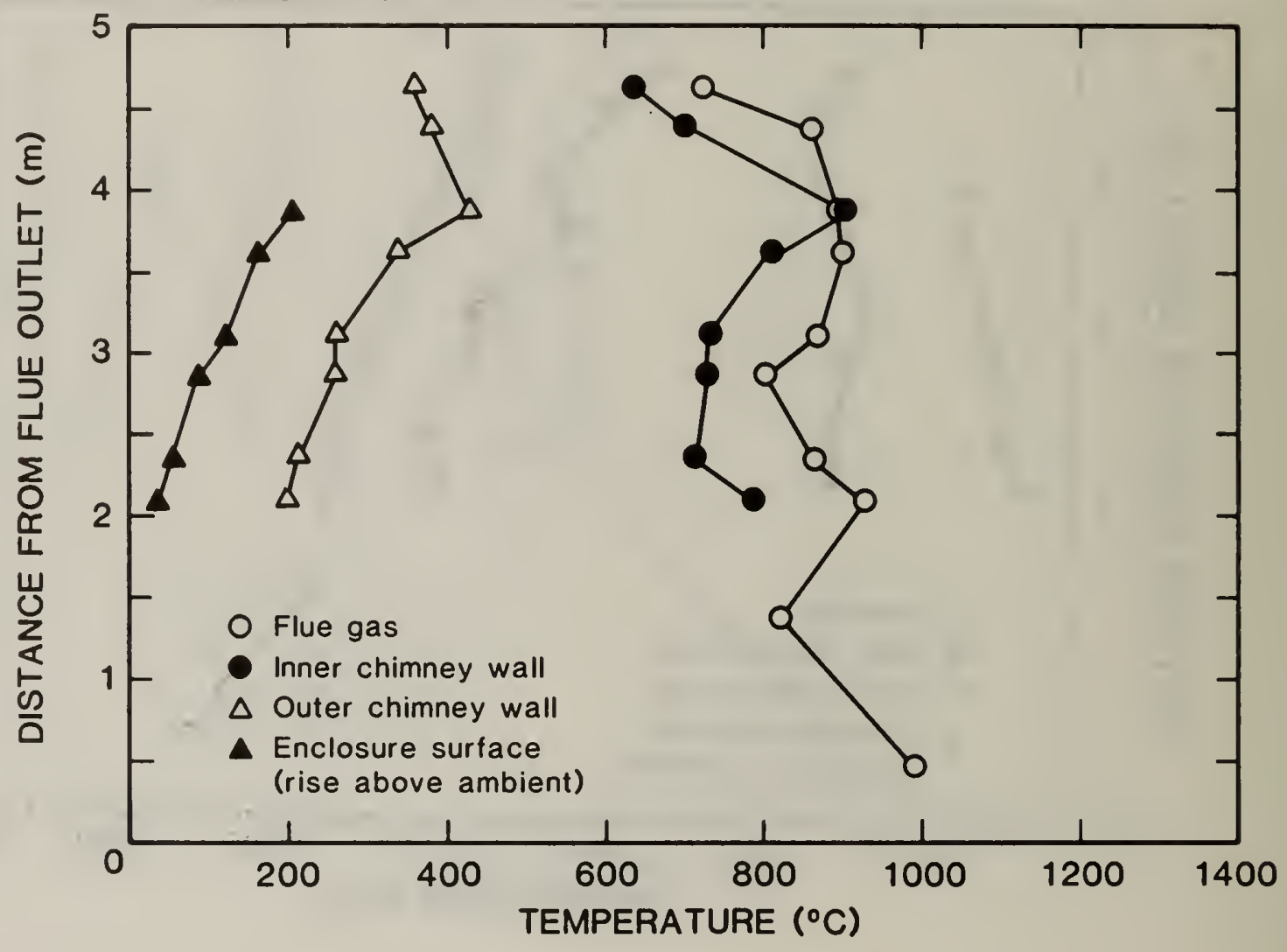

Figure 35. Temperature Profiles During Burnout Test of Chimney 1, Test 4. 


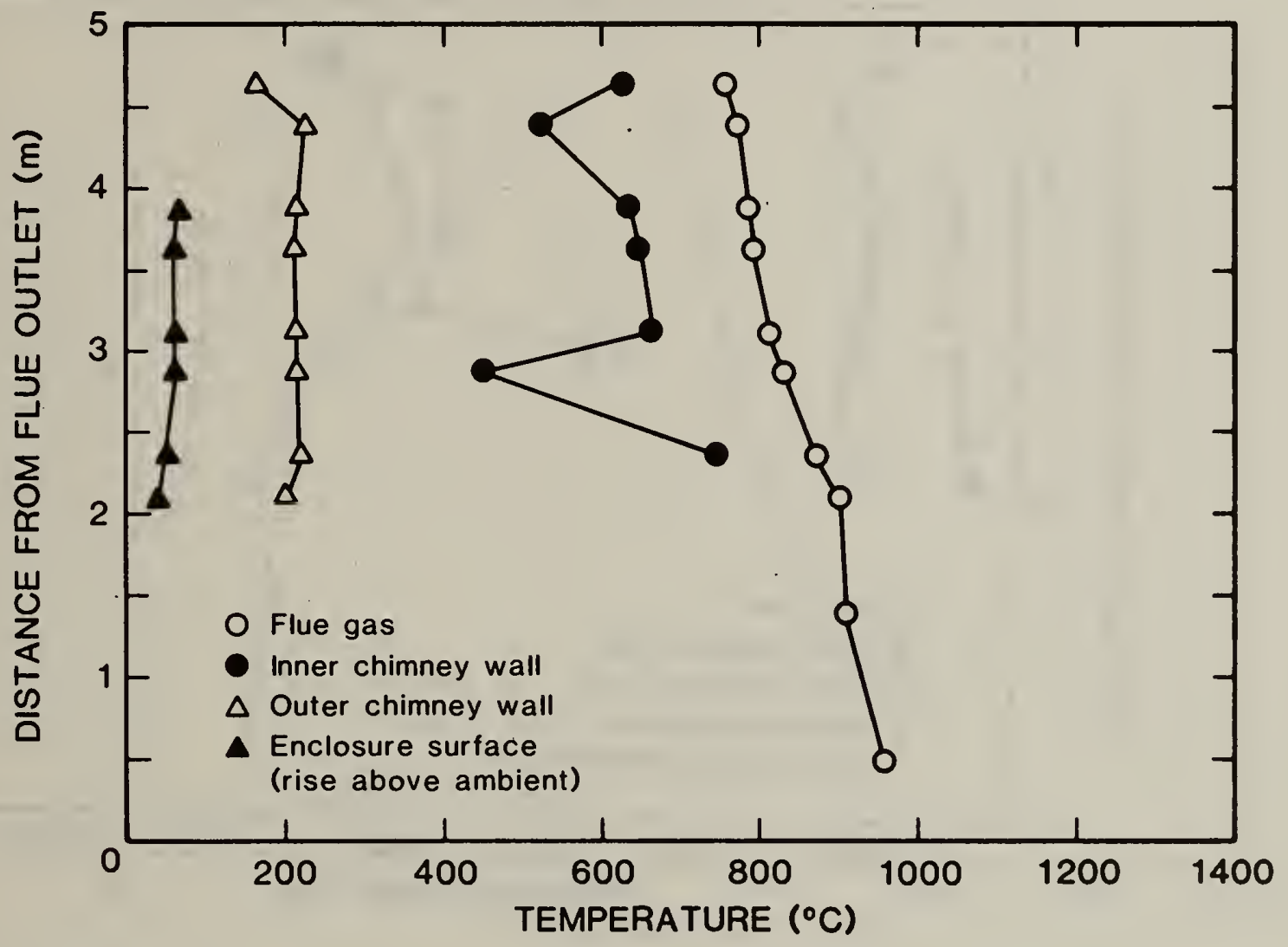

Figure 36. Temperature Profiles During Burnout Test of Chimney 2, Test 5. 


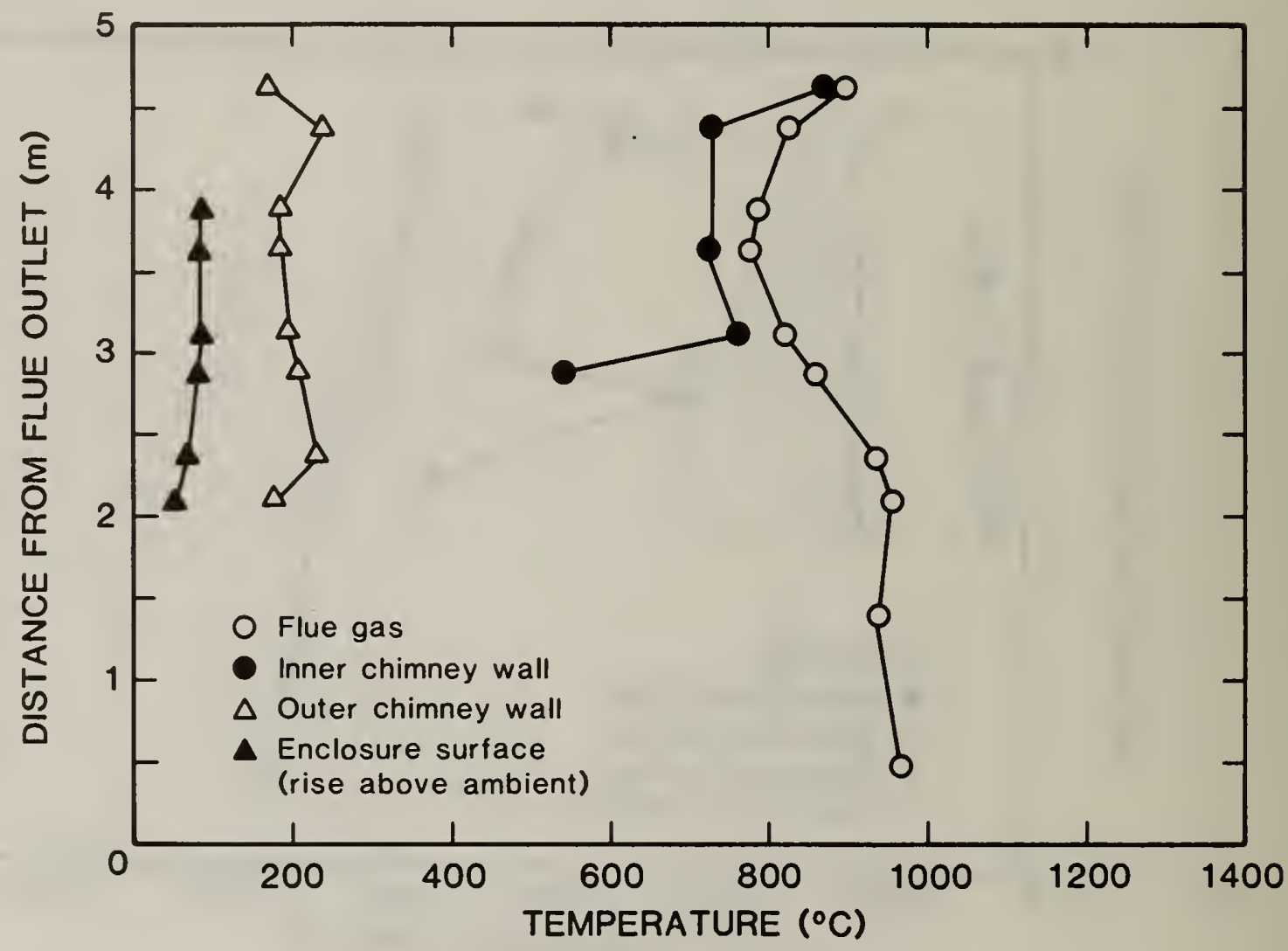

Figure 37. Temperature Profiles During Burnout Test of Chimney 2, Test 6. 


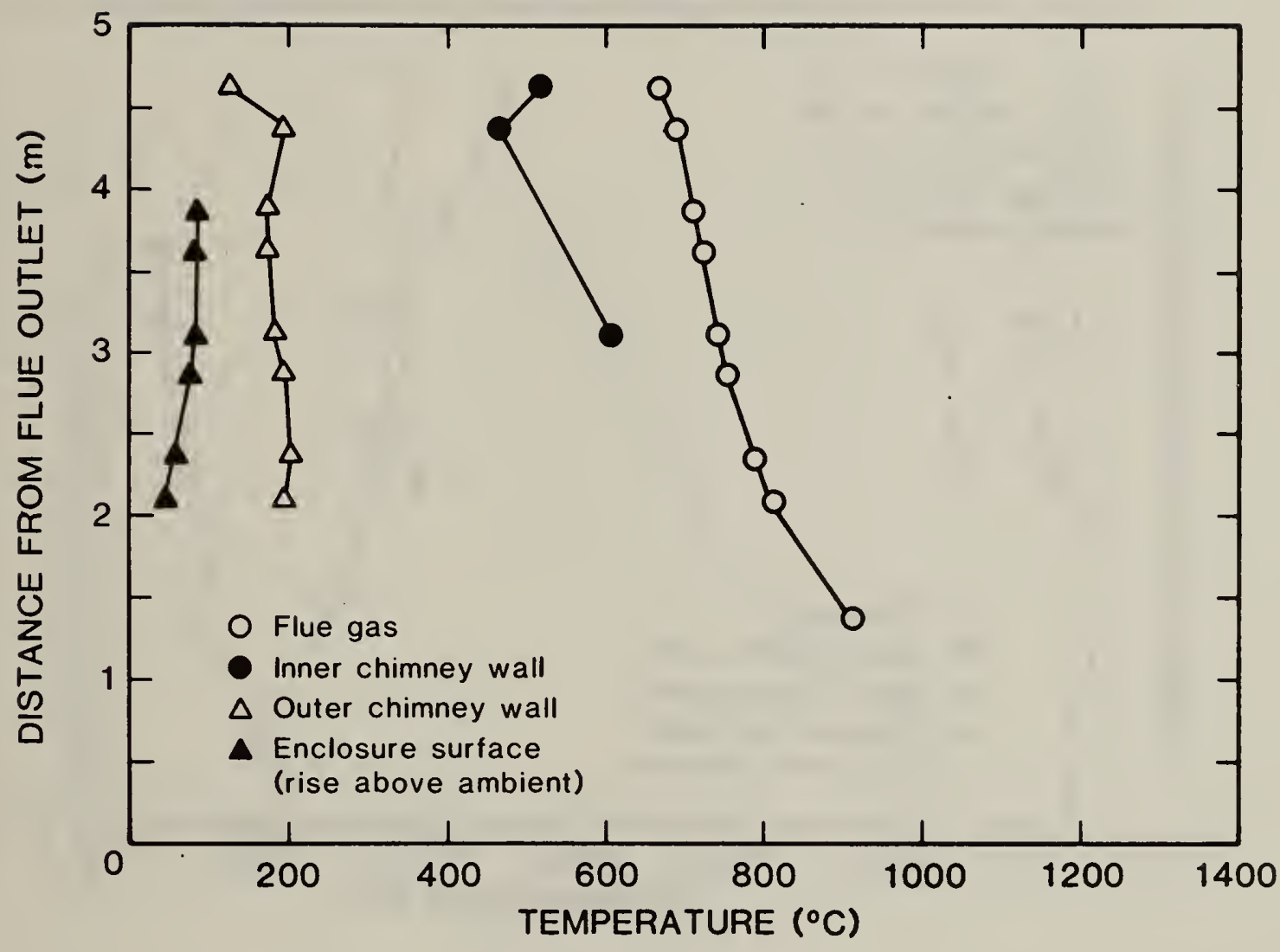

Figure 38. Temperature Profiles During Burnout Test of Chimney 2, Test 7. 


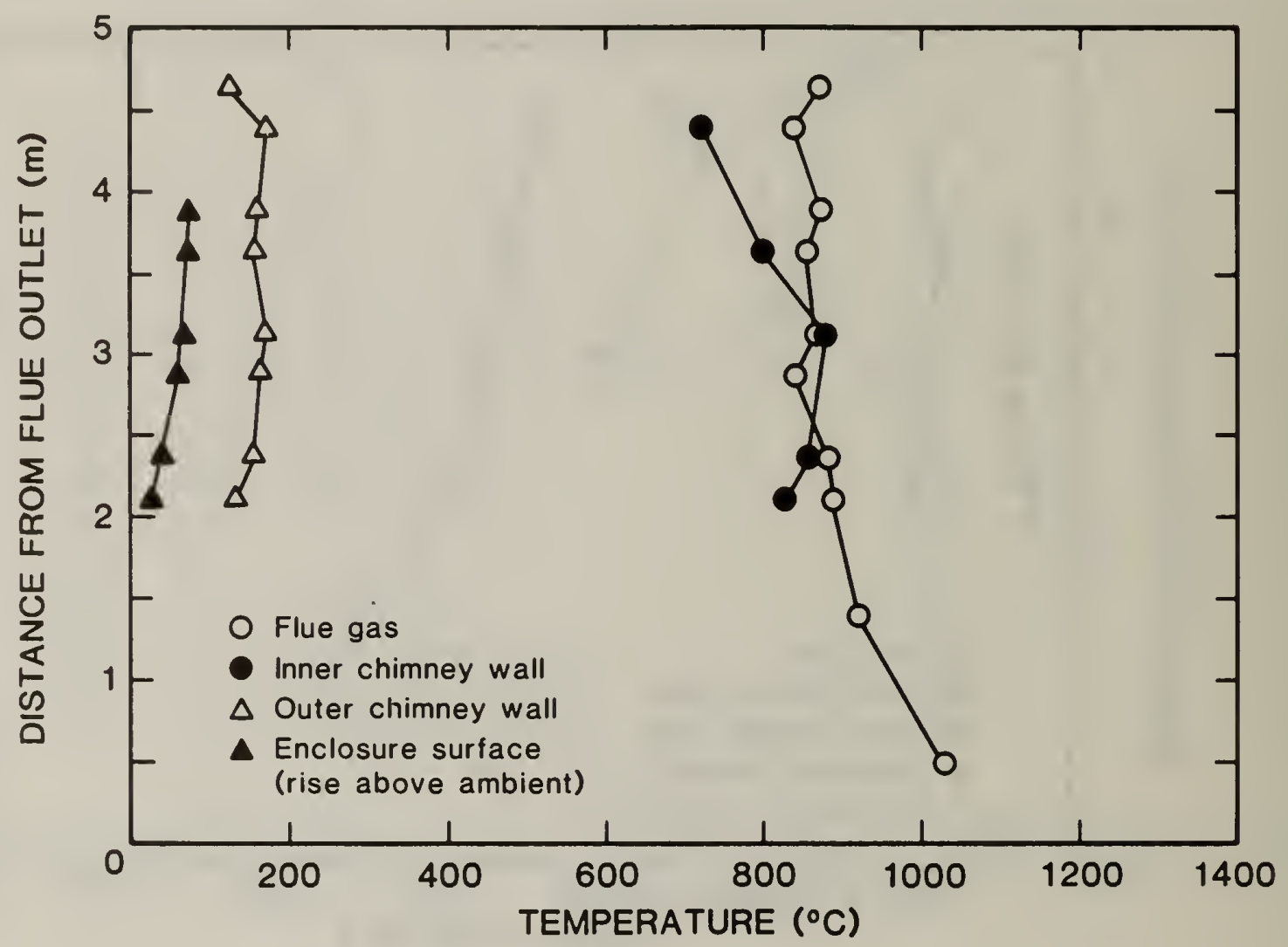

F1gure 39. Temperature Profiles During Burnout Test of Chimney 2, Test 8. 


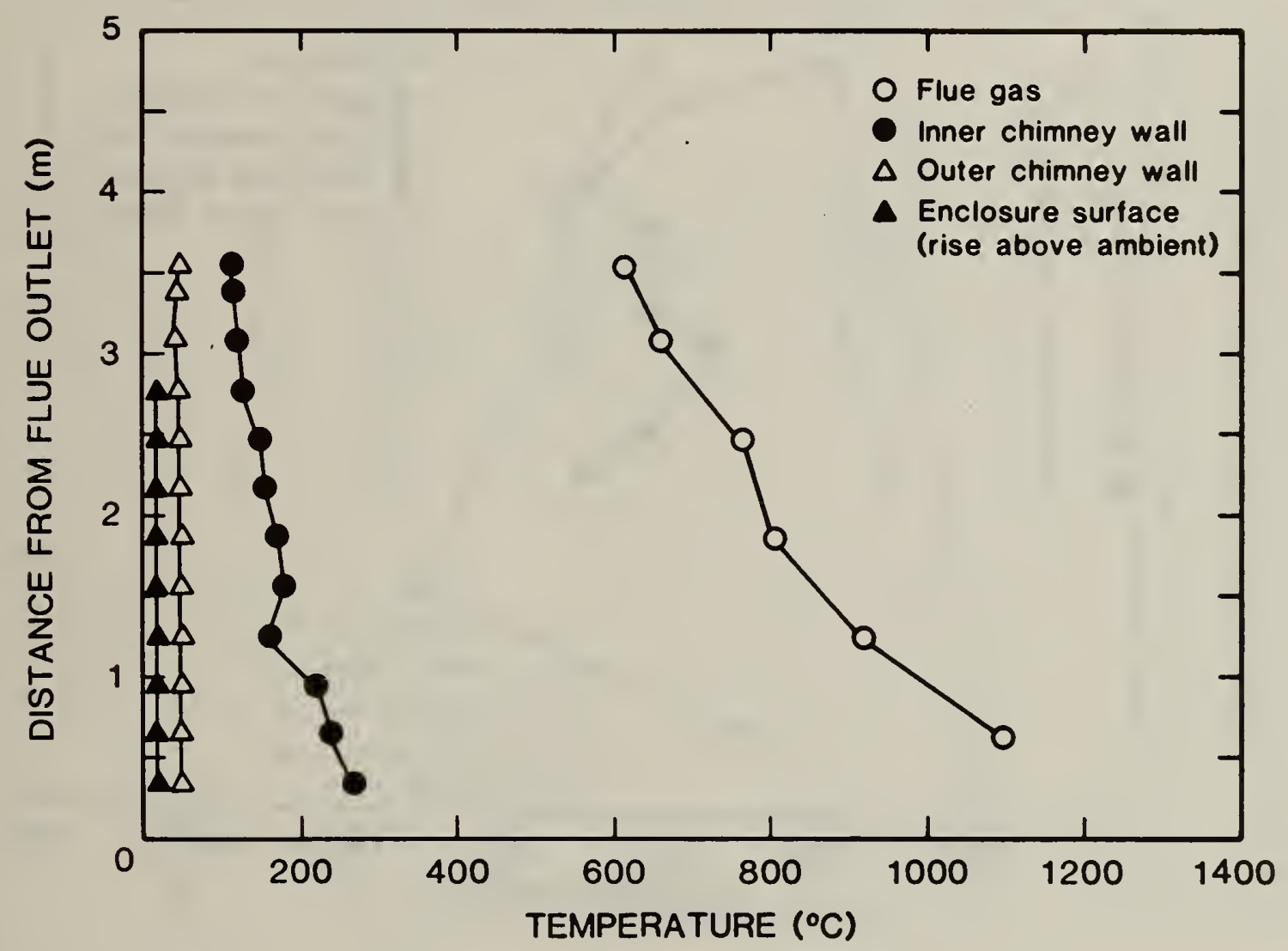

Figure 40. Temperature Profiles During Burnout Test of Chimney 3, Test 9. 


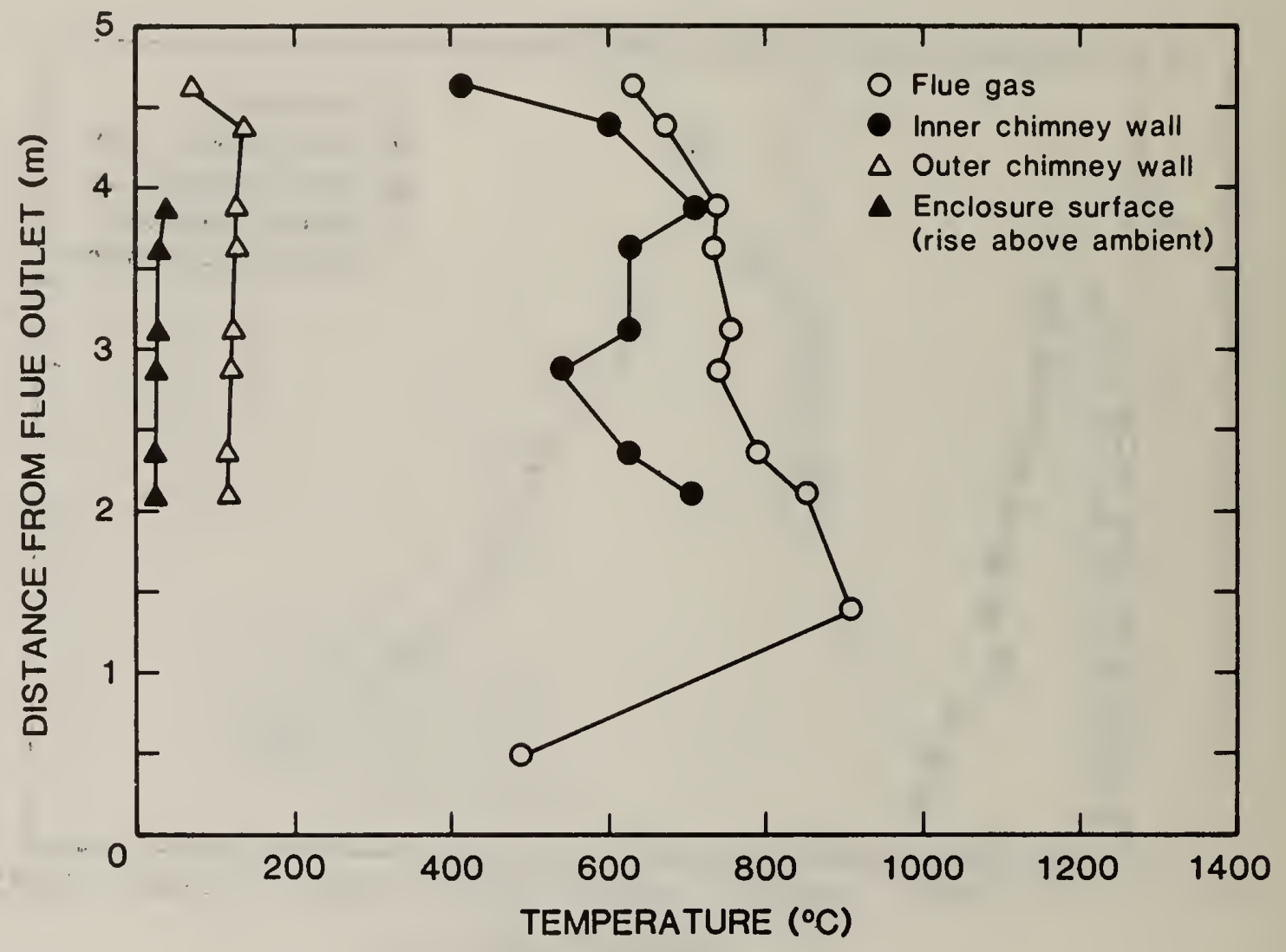

Figure 41. Temperature Profiles During Burnout Test of Chimney 4, Test 10. 


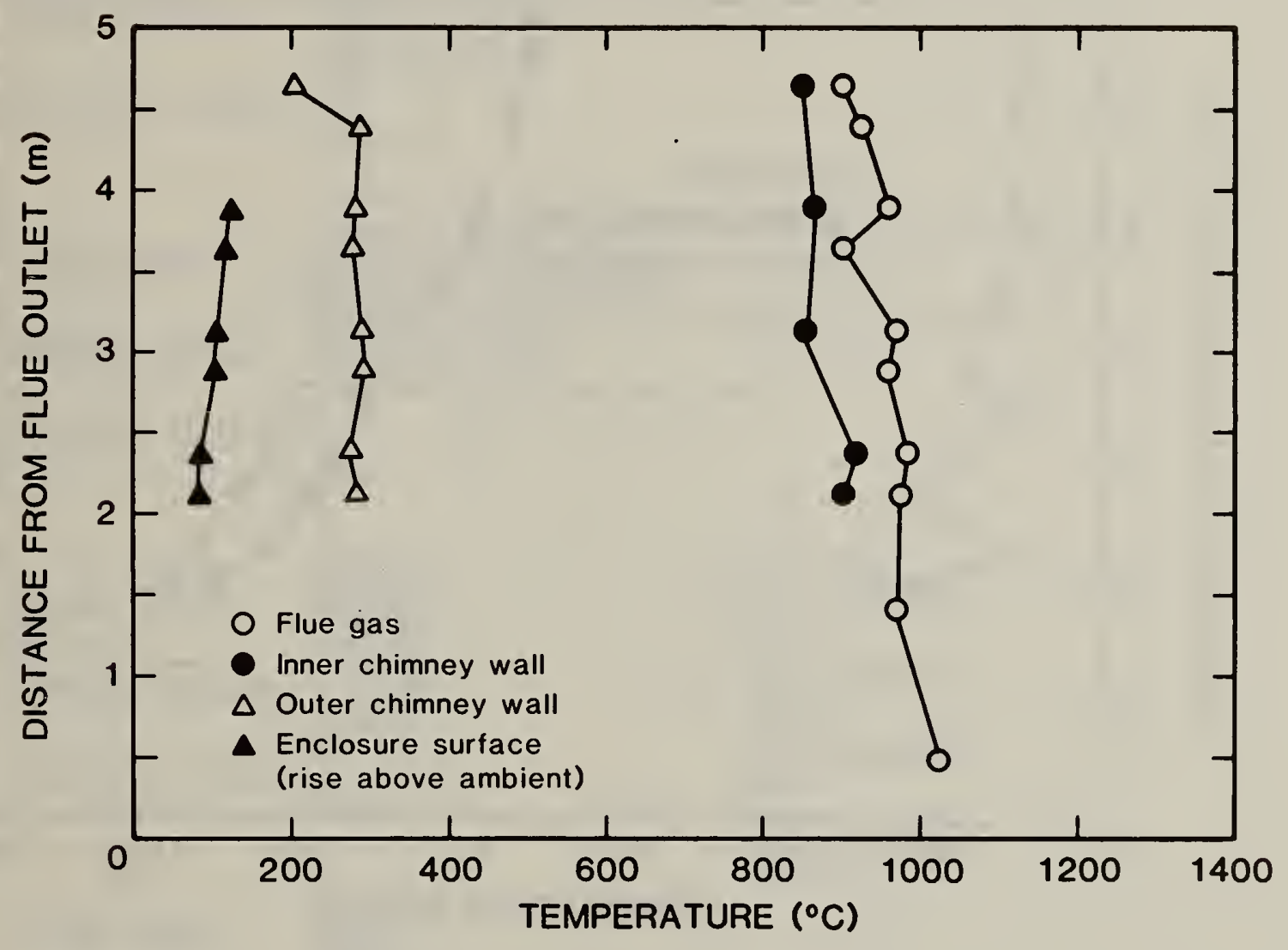

Figure 42. Temperature Profiles During Burnout Test of Chimney 4, Test 11. 


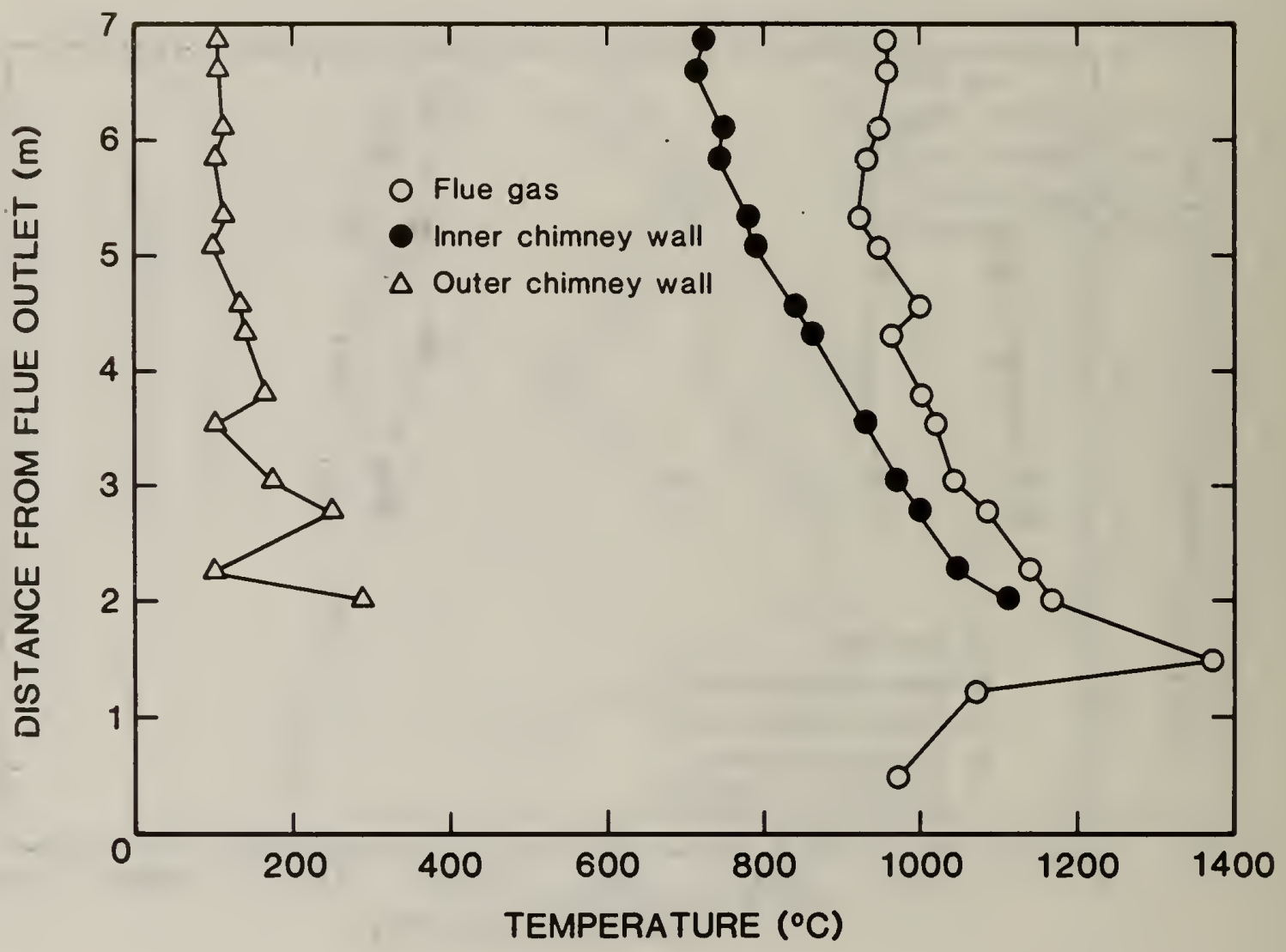

Figure 43. Temperature Profiles During Burnout Test of Chimney 5, Test 12. 


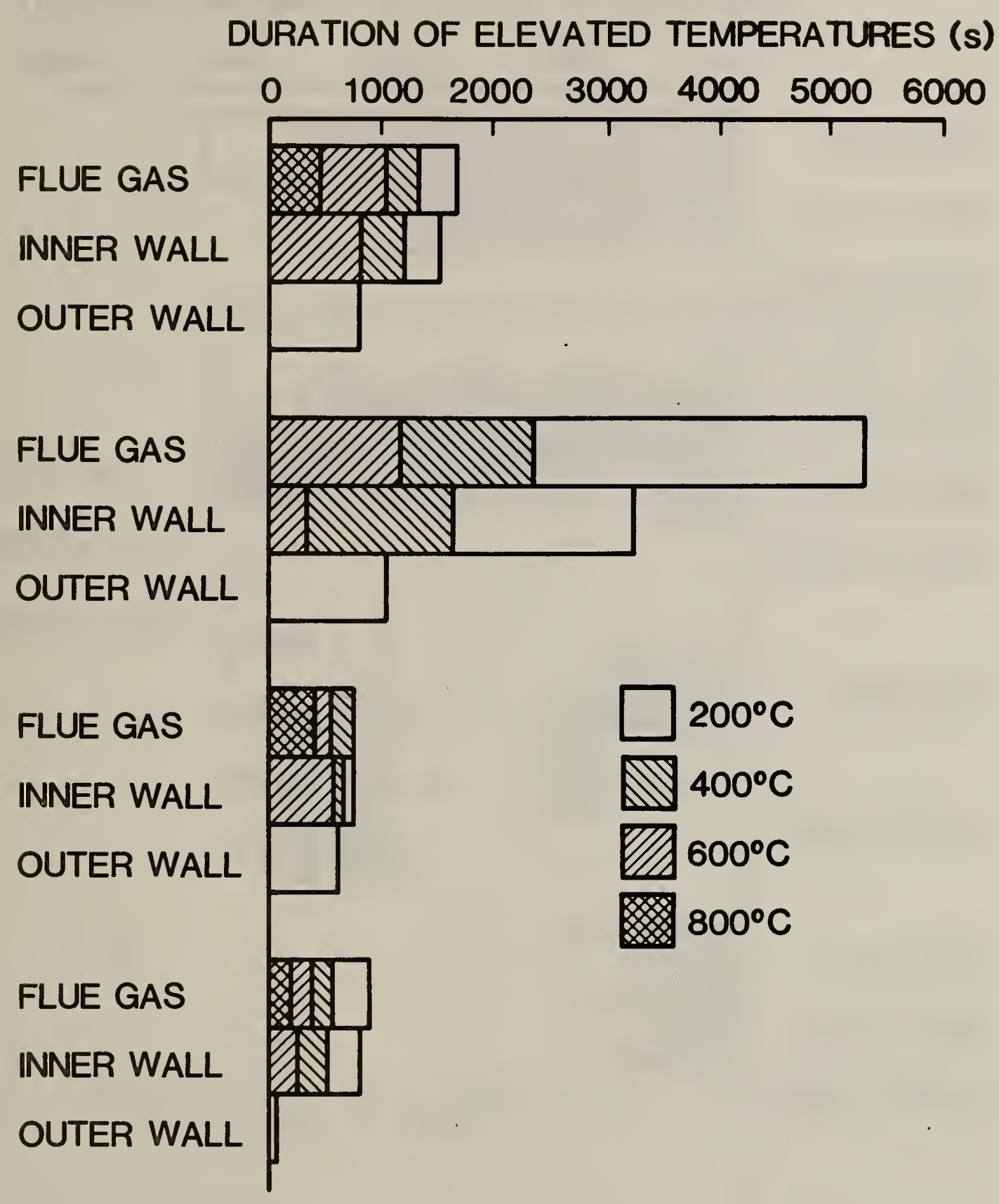

Figure 44. Duration of Elevated Temperatures During Chimney Burnout Tests of Chimney 1 . 


\section{DURATION OF ELEVATED TEMPERATURES (s)}

FLUE GAS

INNER WALL

OUTER WALL

$\begin{array}{llll}0 & 1000 \quad 2000 \quad 3000 \quad 4000\end{array}$

FLUE GAS

INNER WALL

OUTER WALL

FLUE GAS

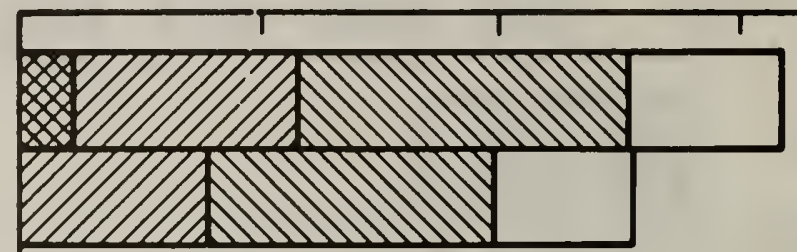

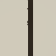

OUTER WALL
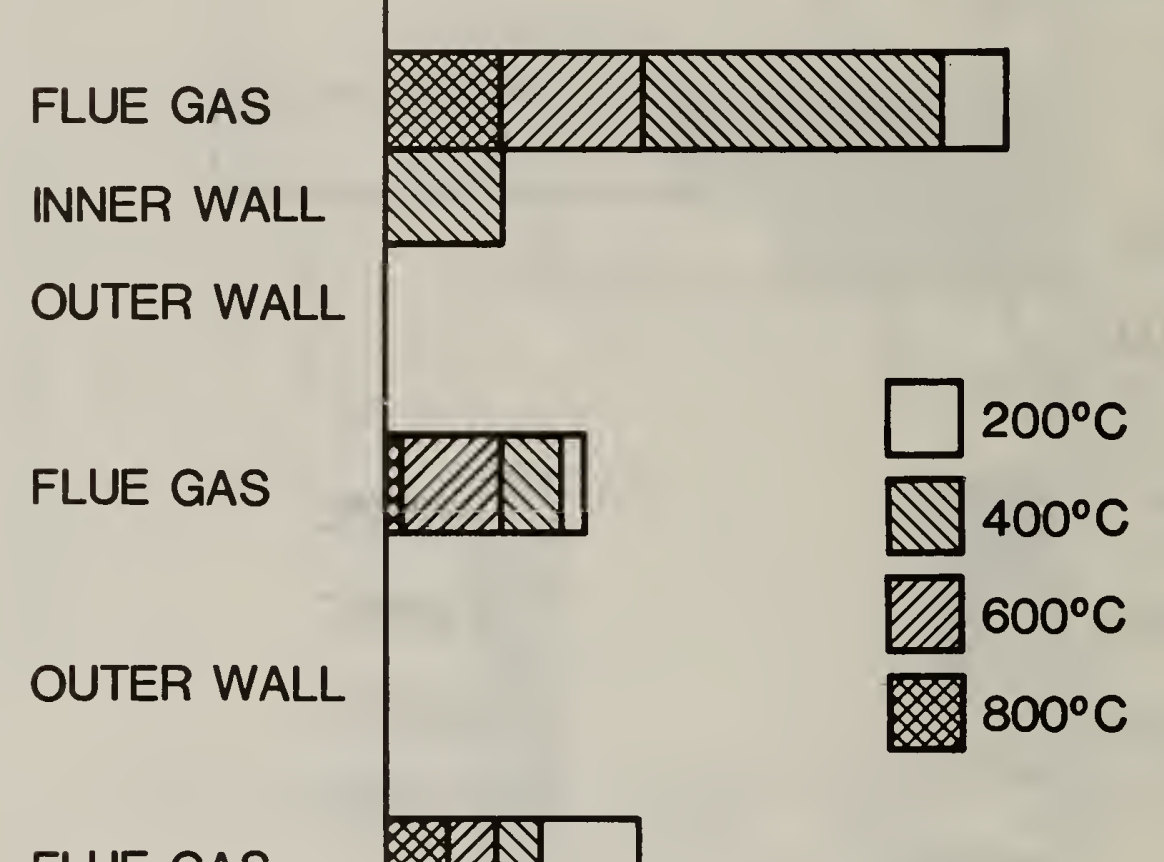

\section{FLUE GAS}

INNER WALL

OUTER WALL
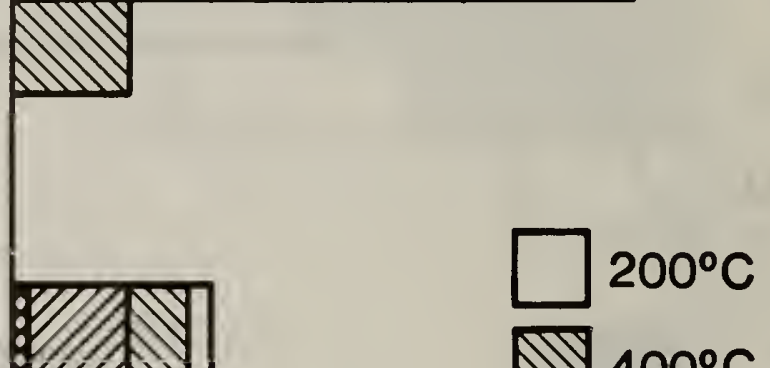

$400^{\circ} \mathrm{C}$

$600^{\circ} \mathrm{C}$

$800^{\circ} \mathrm{C}$

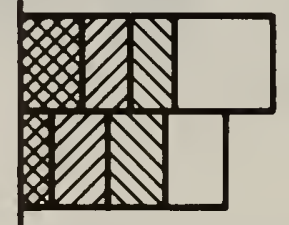

Figure 45. Duration of Elevated Temperatures During Chimney Burnout Tests of Chimney 2. 


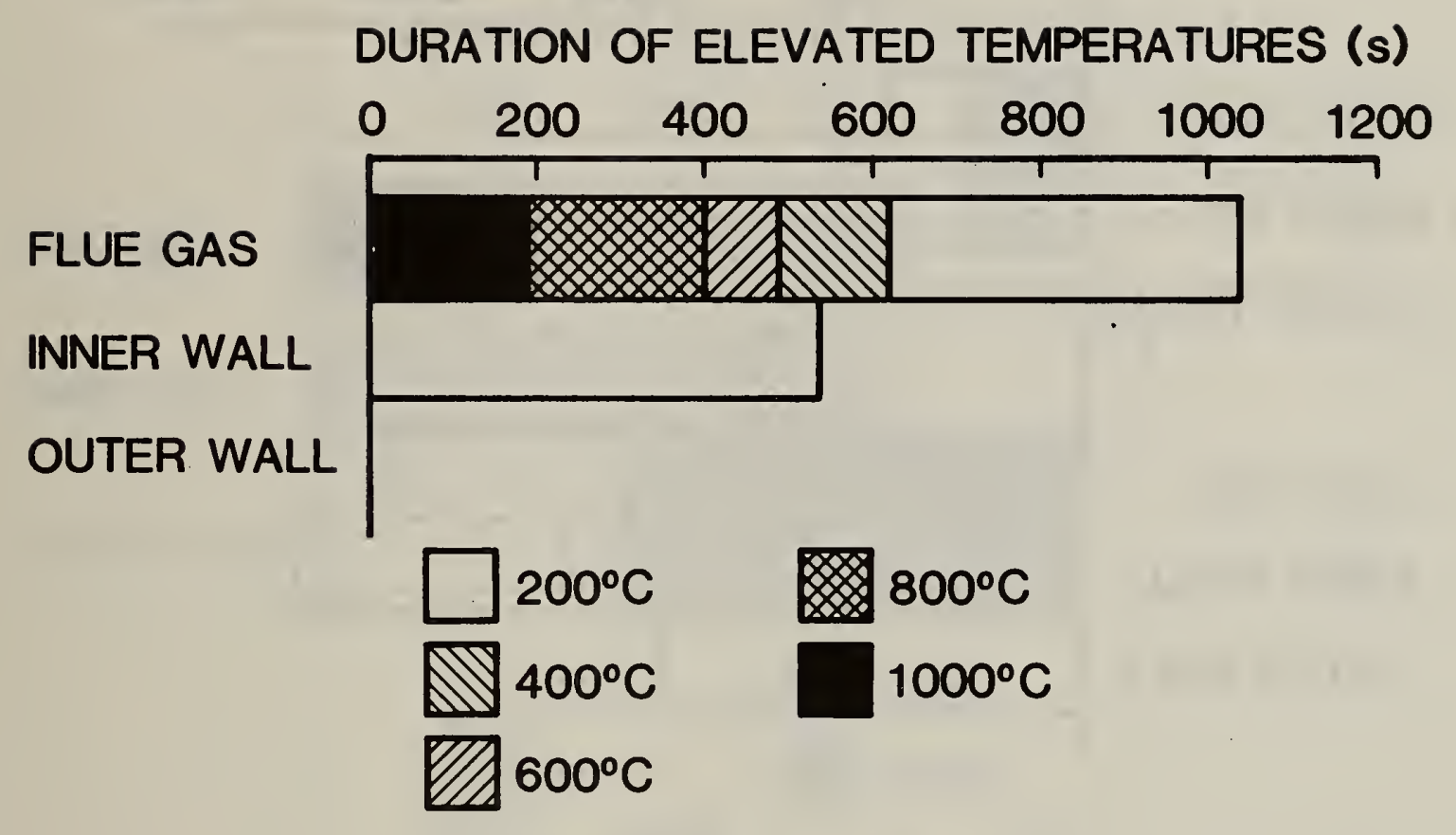

Figure 46. Duration of Elevated Temperatures During Chimney Burnout Tests of Chimney 3. 


\section{DURATION OF ELEVATED TEMPERATURES ( $s$ )}
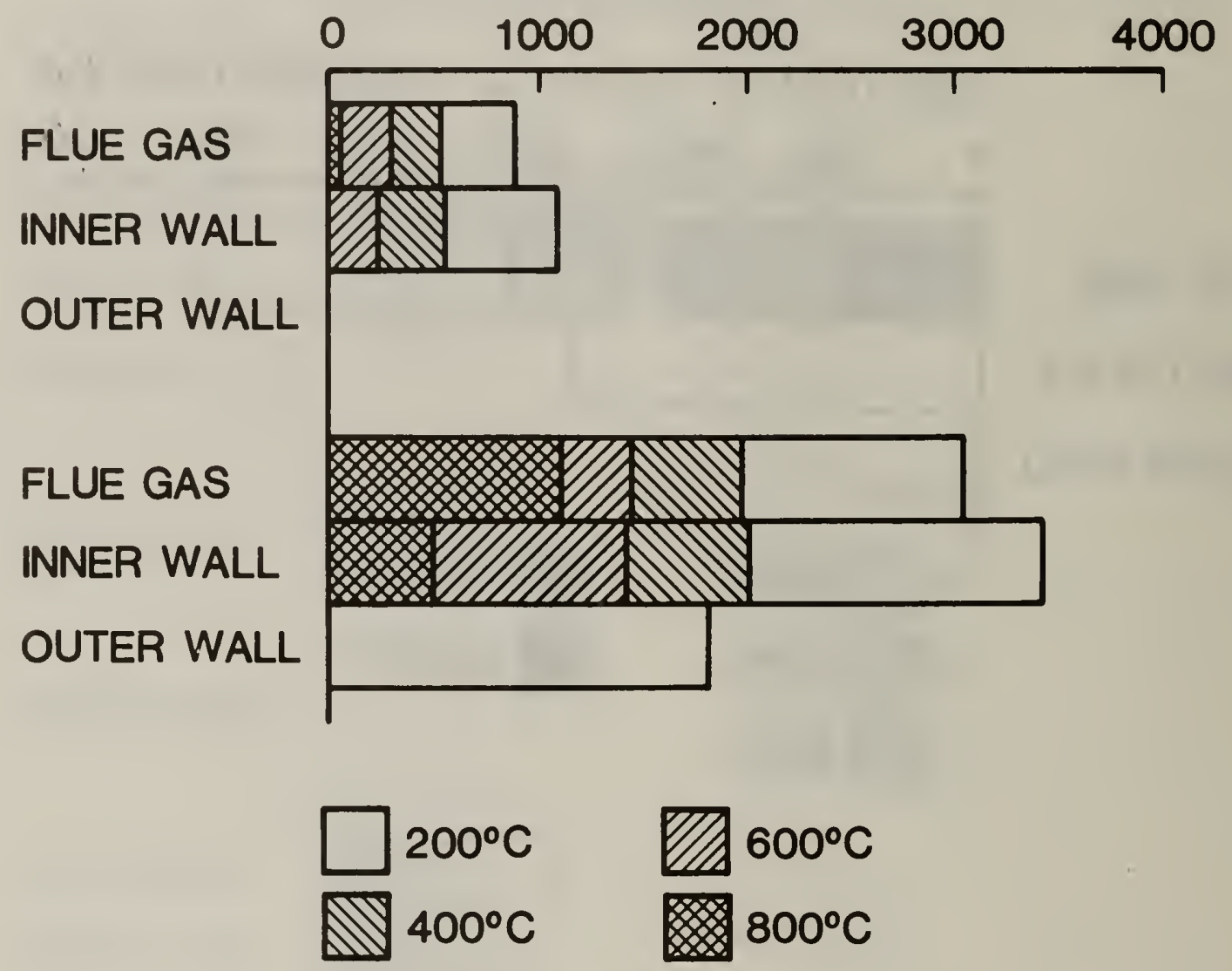

Figure 47. Duration of Elevated Temperatures During Chimney Burnout Tests of Chimney 4. 


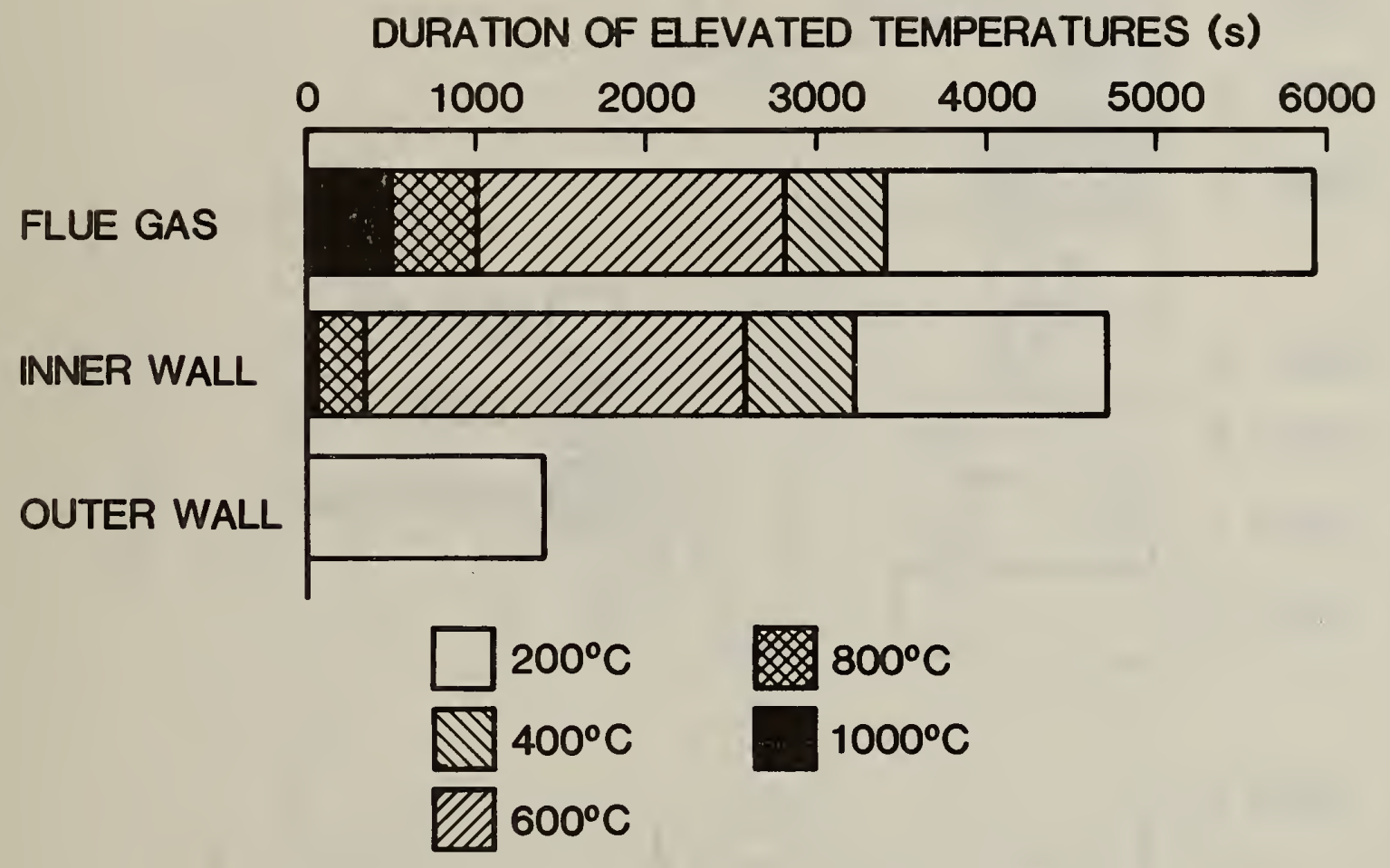

Figure 48. Duration of Elevated Temperatures During Chimney Burnout Tests of Chimney 5. 


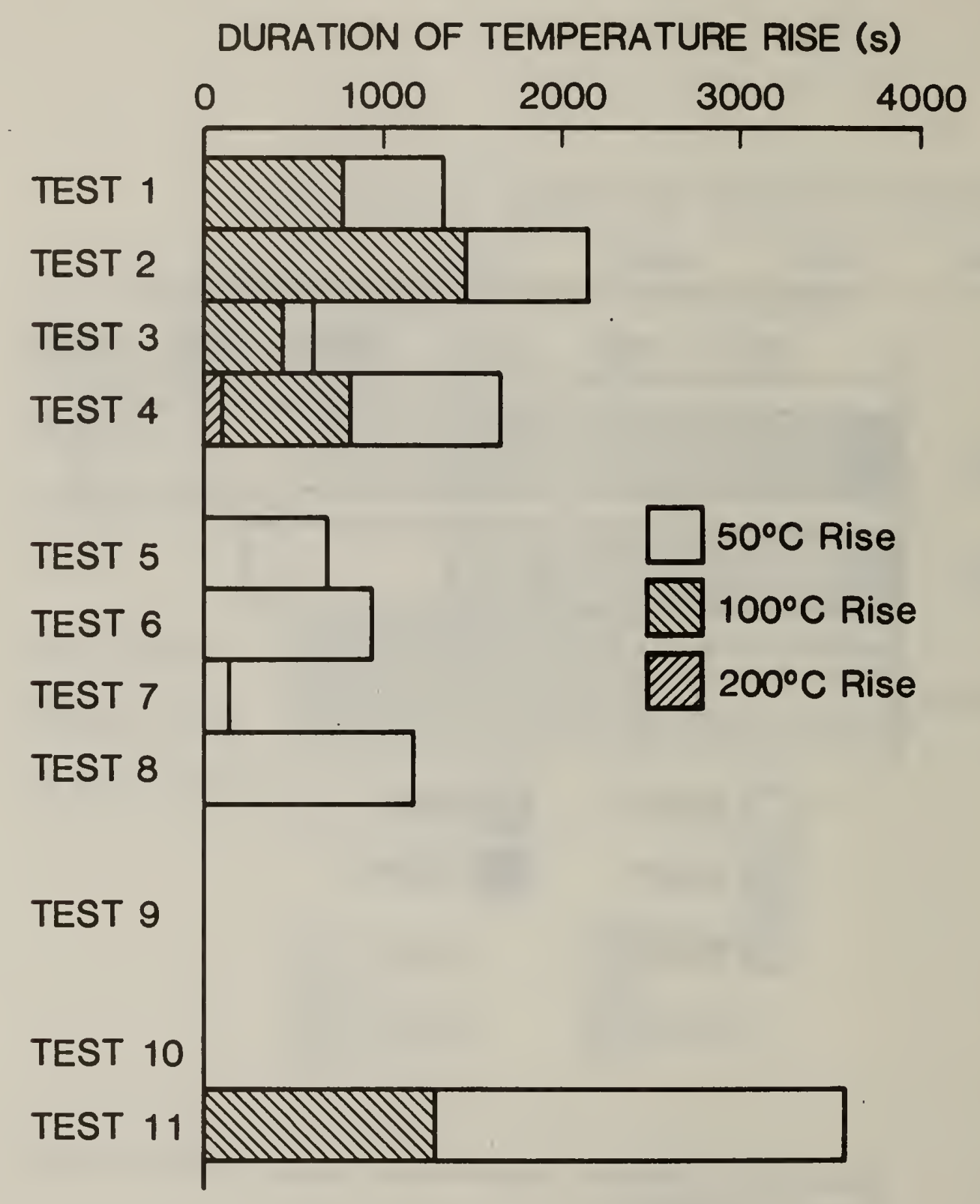

Figure 49. Duration of Temperatures in Excess of $50^{\circ} \mathrm{C}$ on Enclosure Surfaces During Chimney Burnout Tests. 


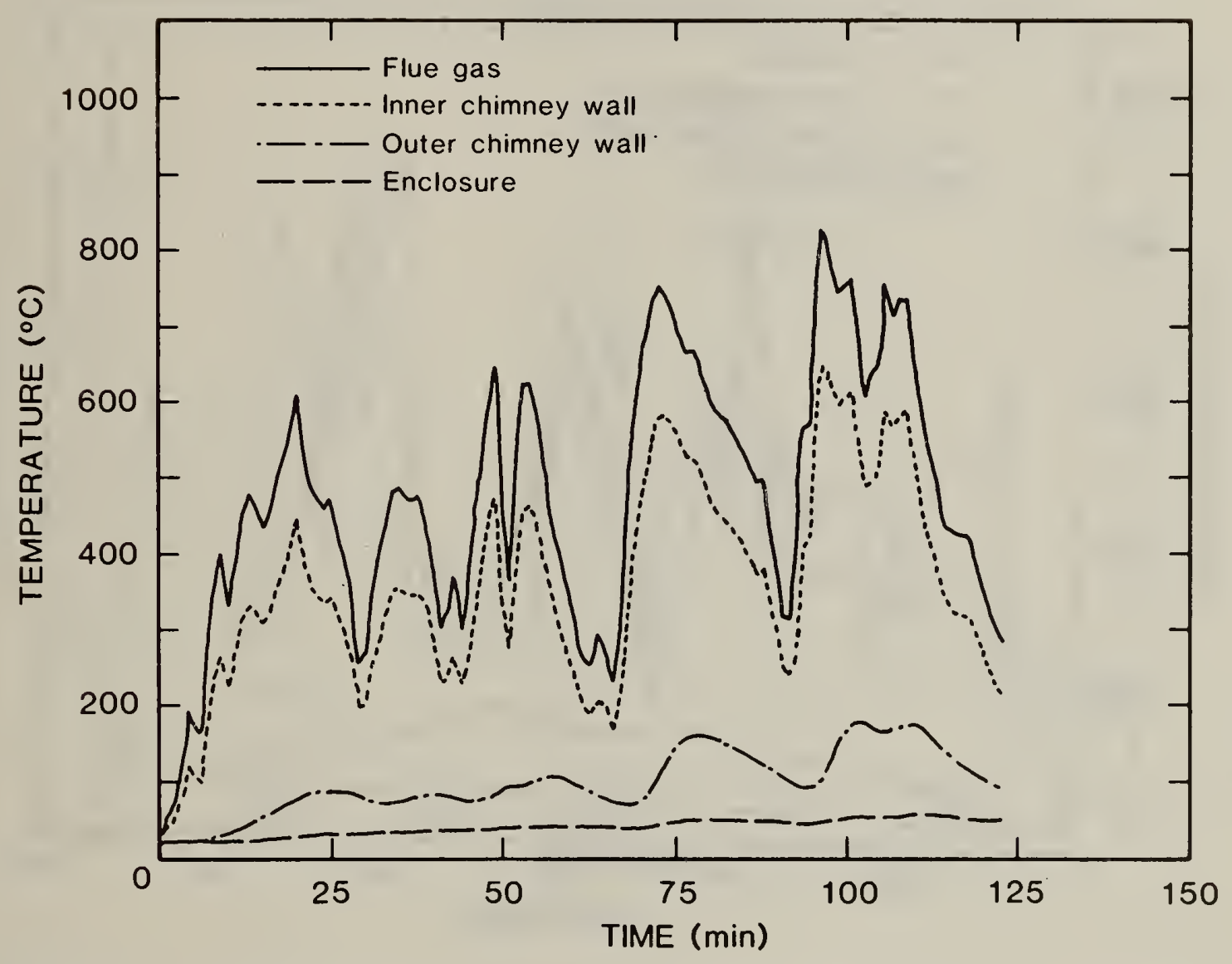

Figure 50. Temperatures at Chimney Base During Overfire Test of Chimney 1. 


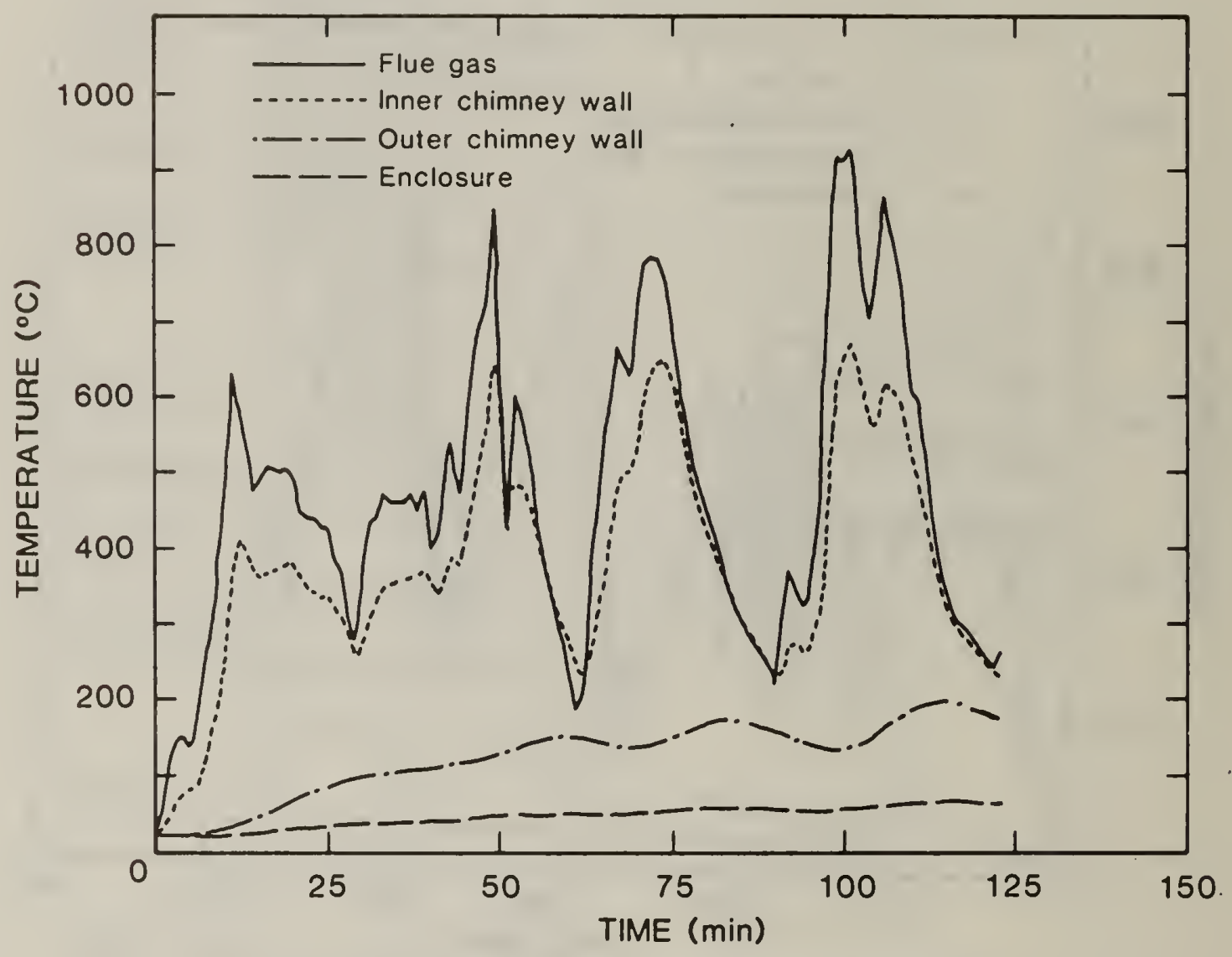

F1gure 51. Temperatures at Ch1mney Base During Overfire Test of Chimney 2. 


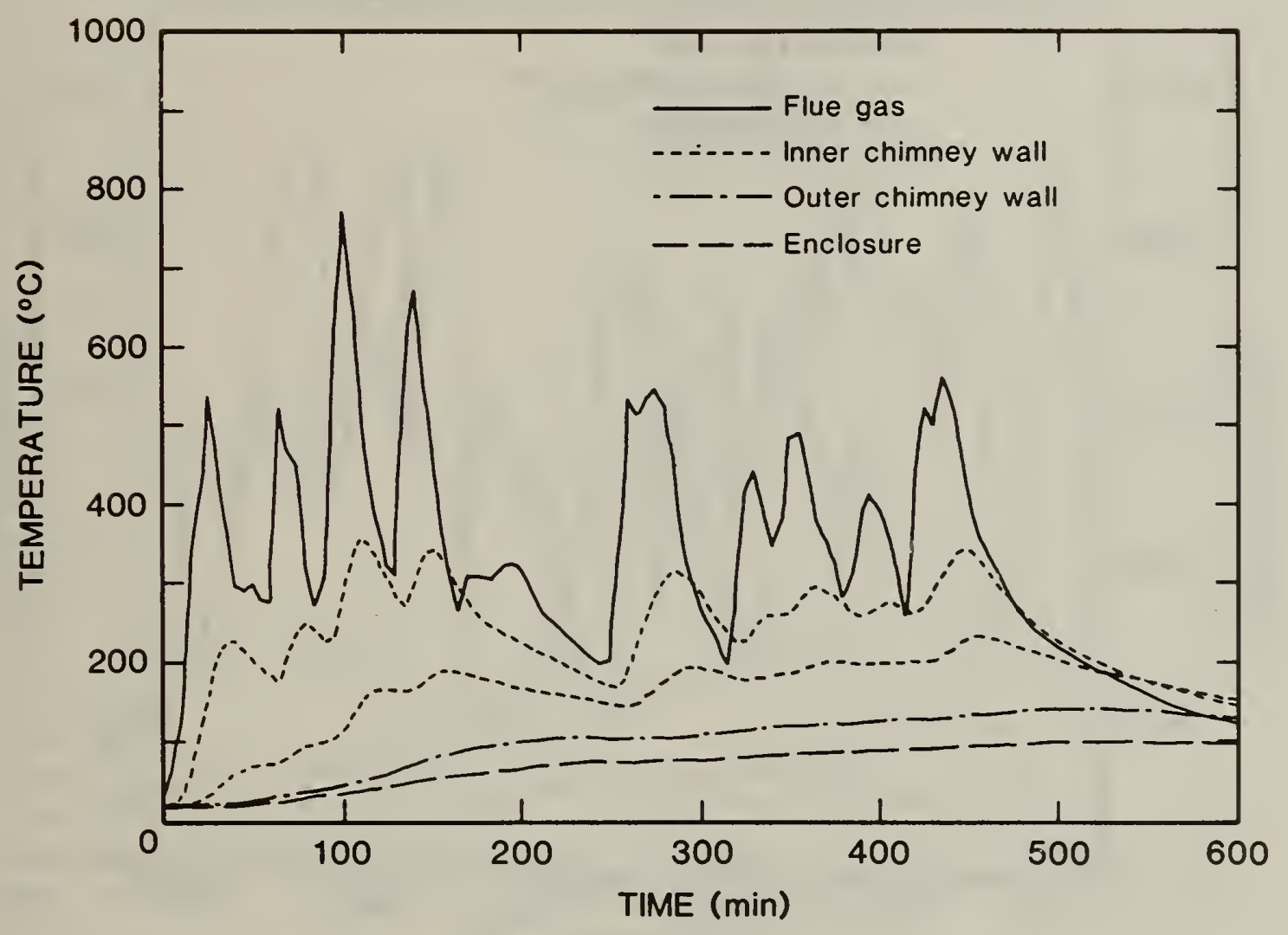

Figure 52. Temperatures at Chimney Base During Overfire Test of Chimney 3. 


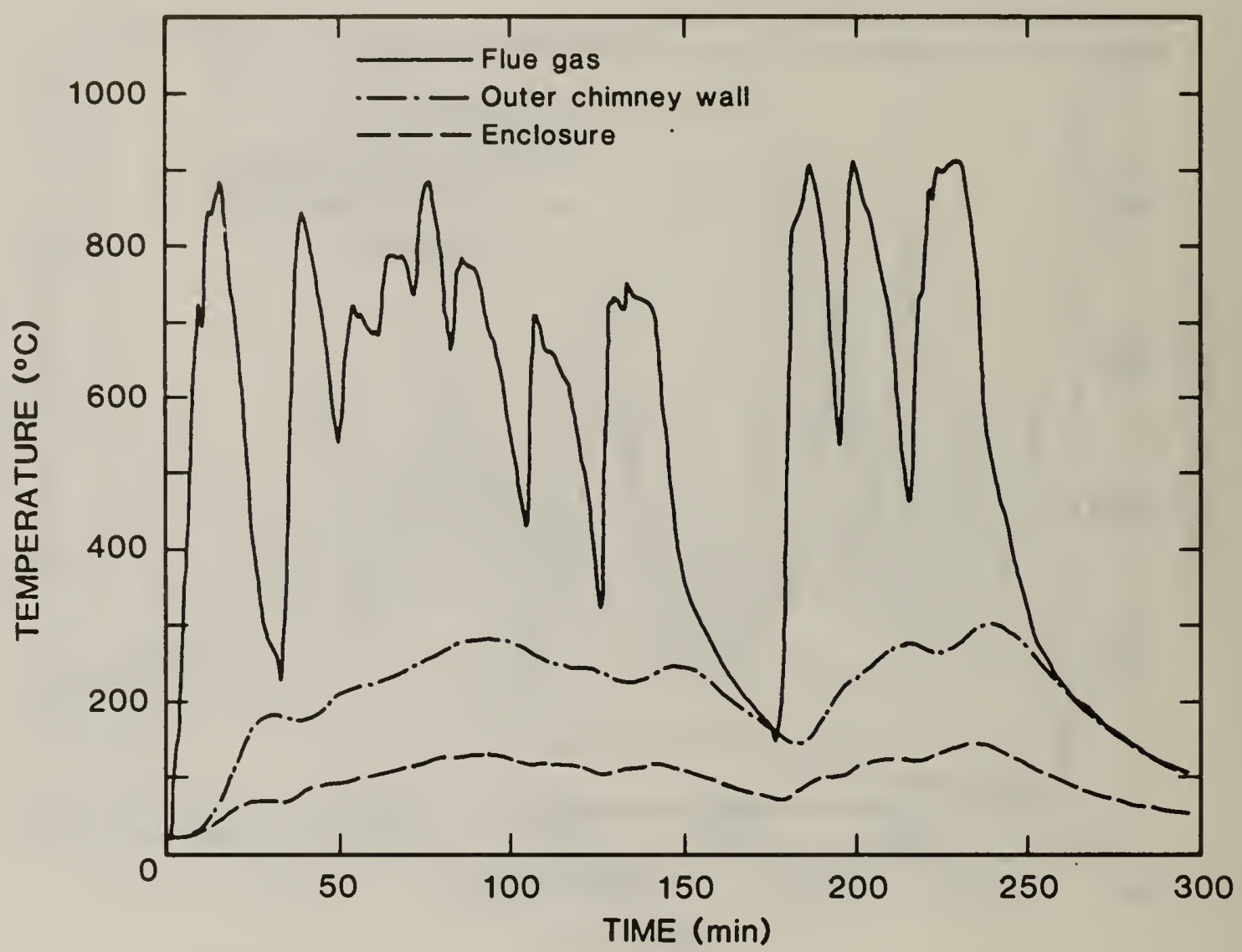

Figure 53. Temperatures at Chimney Base During Overfire Test of Chimney 4. 


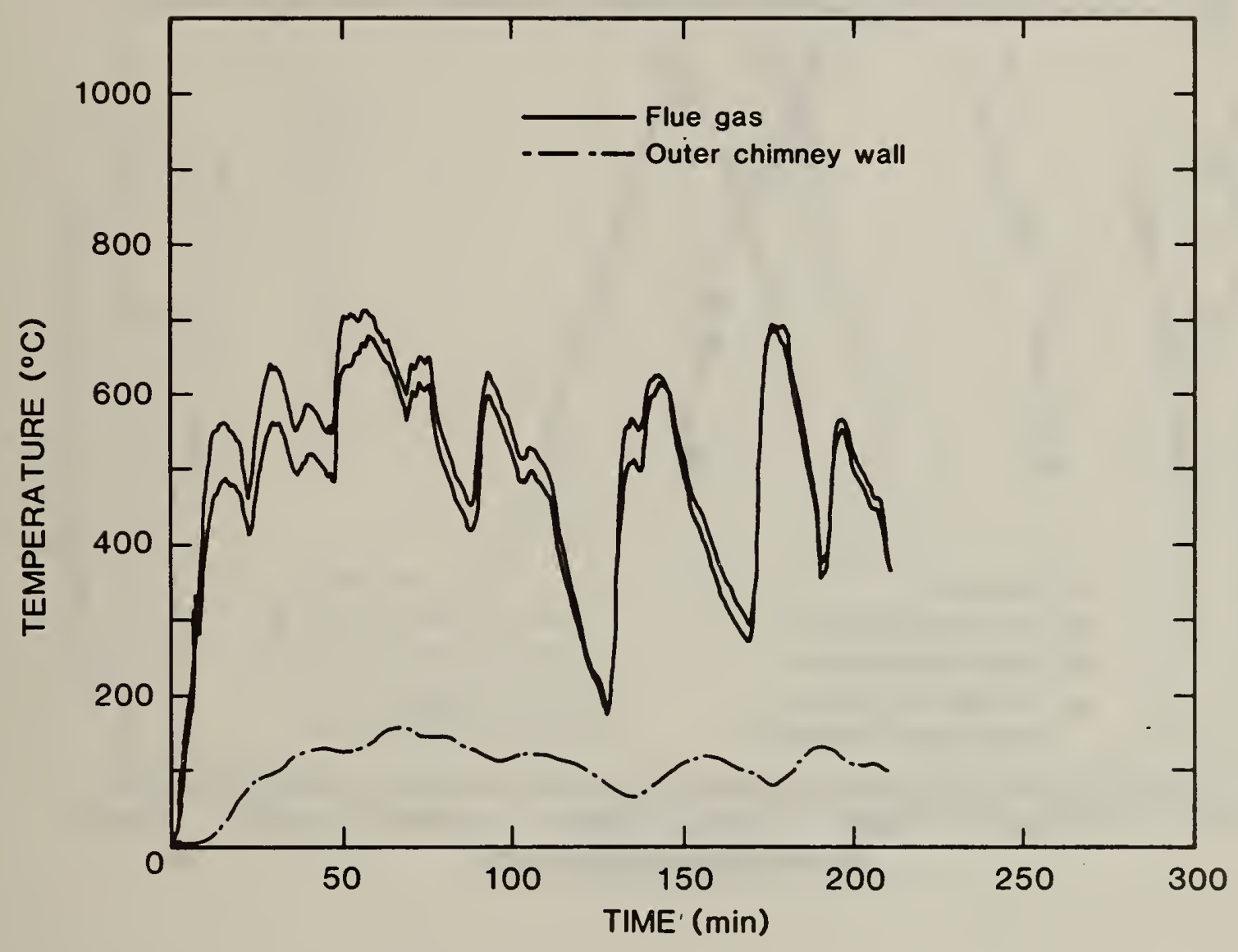

Figure 54. Temperatures at Chimney Base During Overfire Test of Chimney 5. 


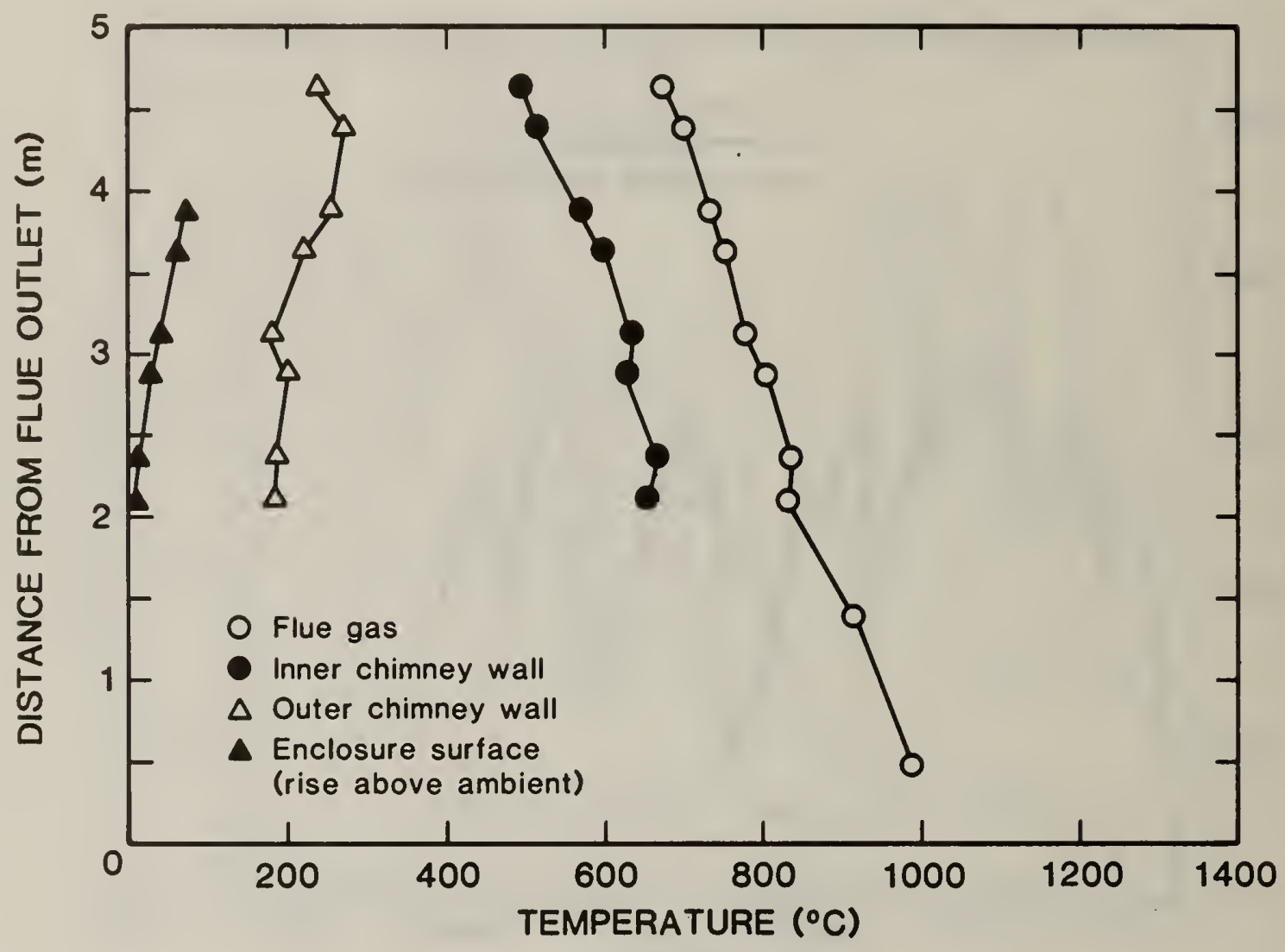

Figure 55. Temperature Profiles During Overfire Test of Chimney 1. 


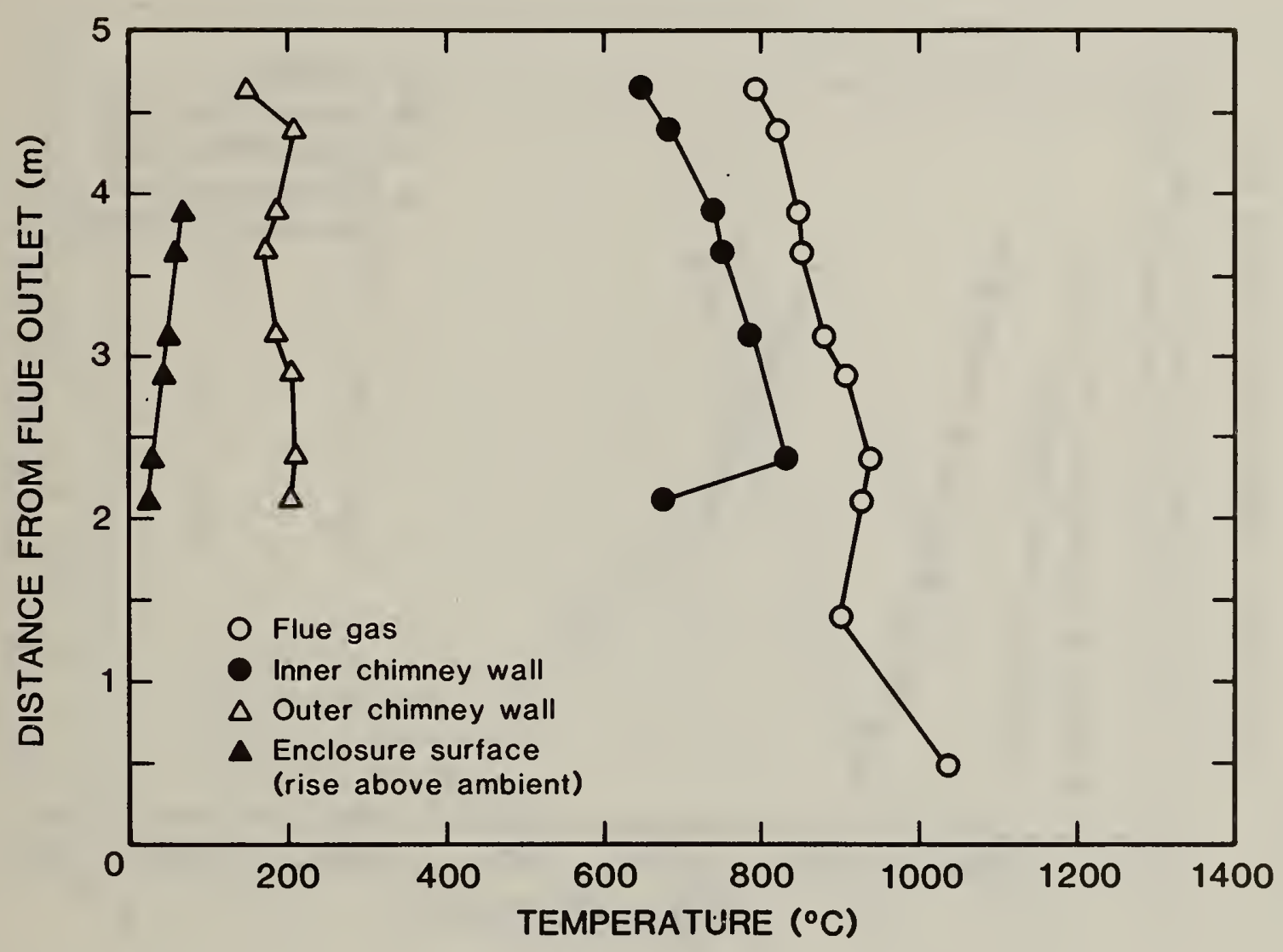

Figure 56. Temperature Profiles During Overfire Test of Chimney 2. 


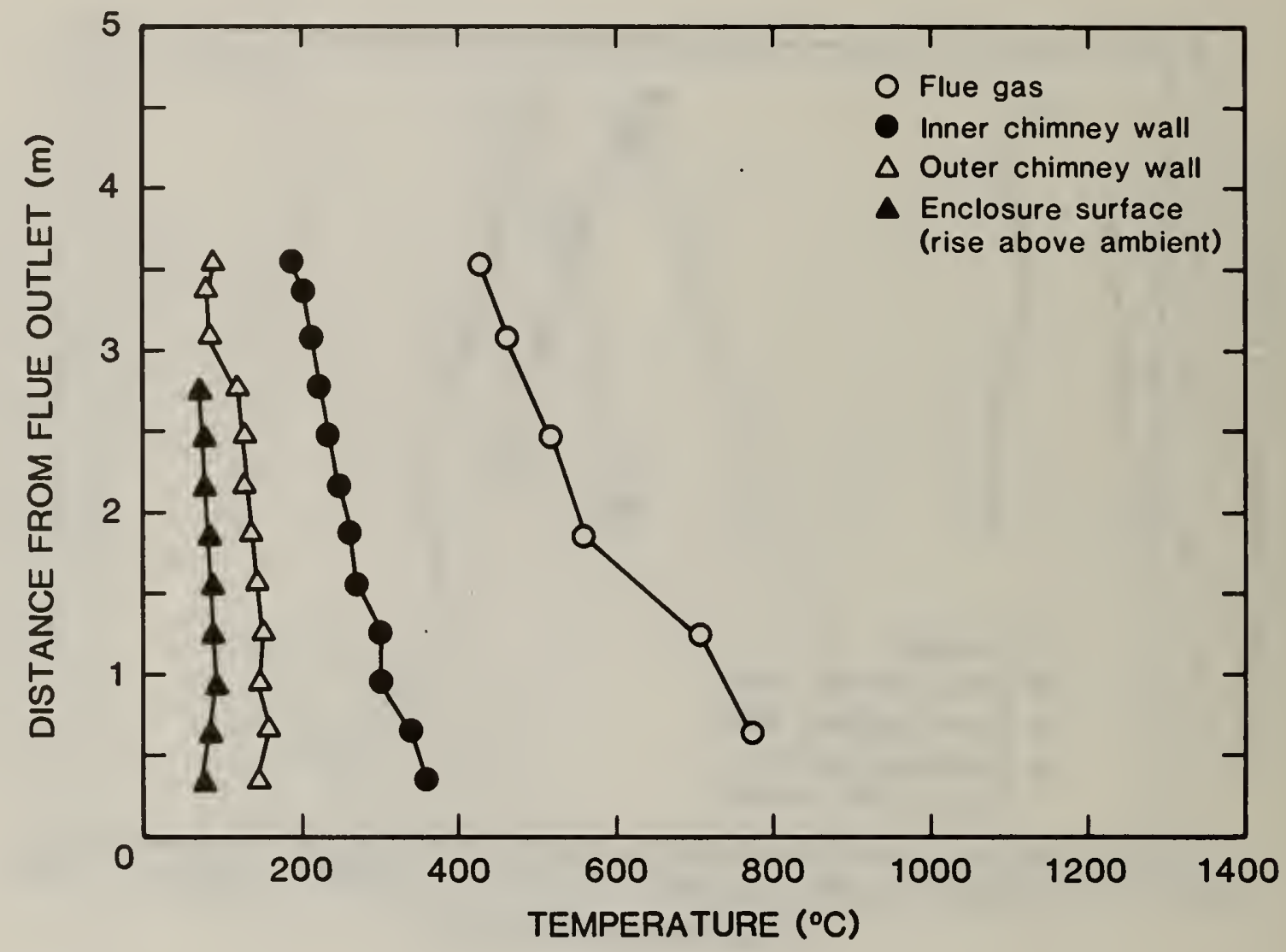

Figure 57. Temperature Profiles During Overfire Test of Chimney 3. 


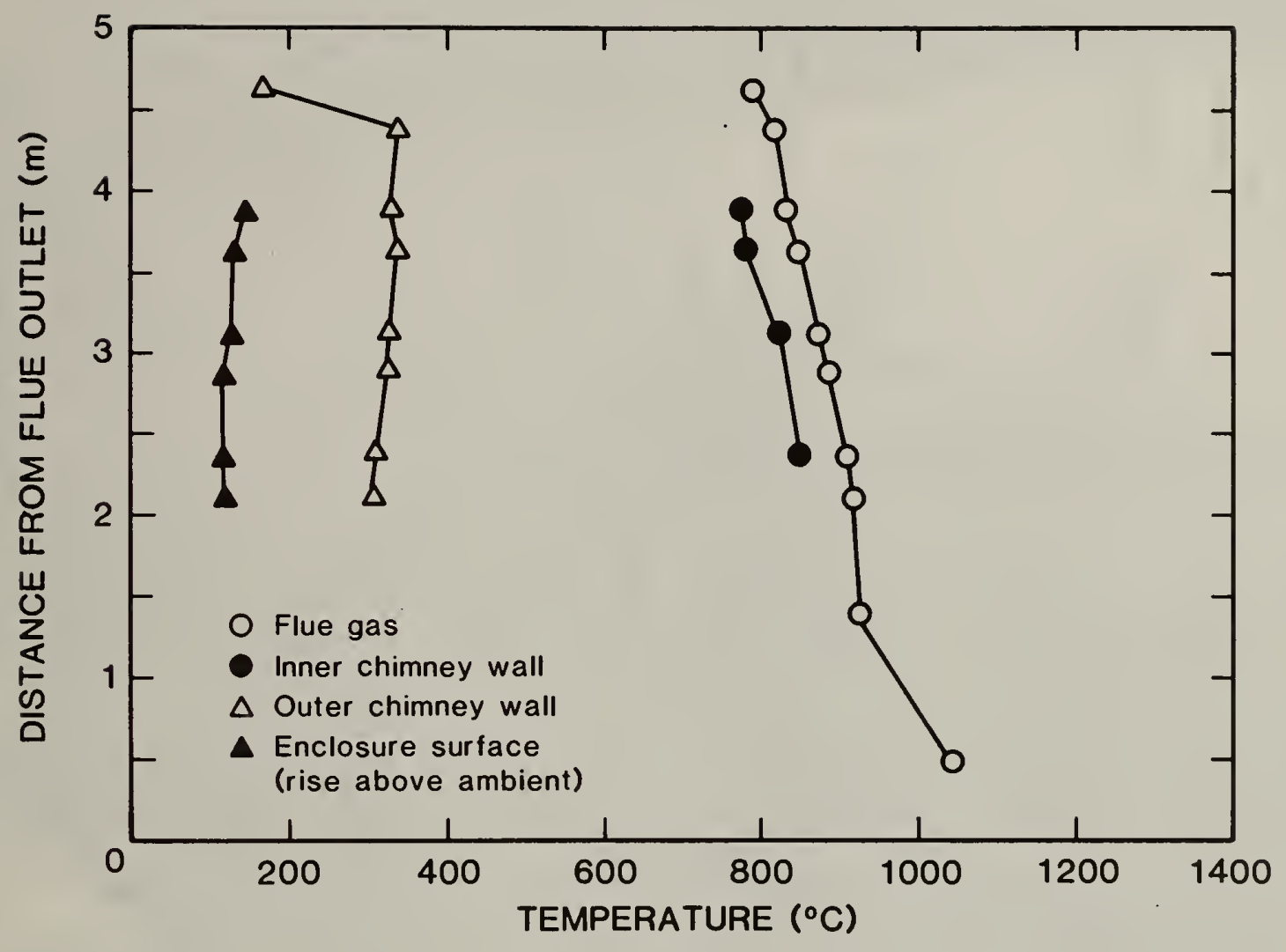

Figure 58. Temperature Profiles During Overfire Test of Chimney 4. 


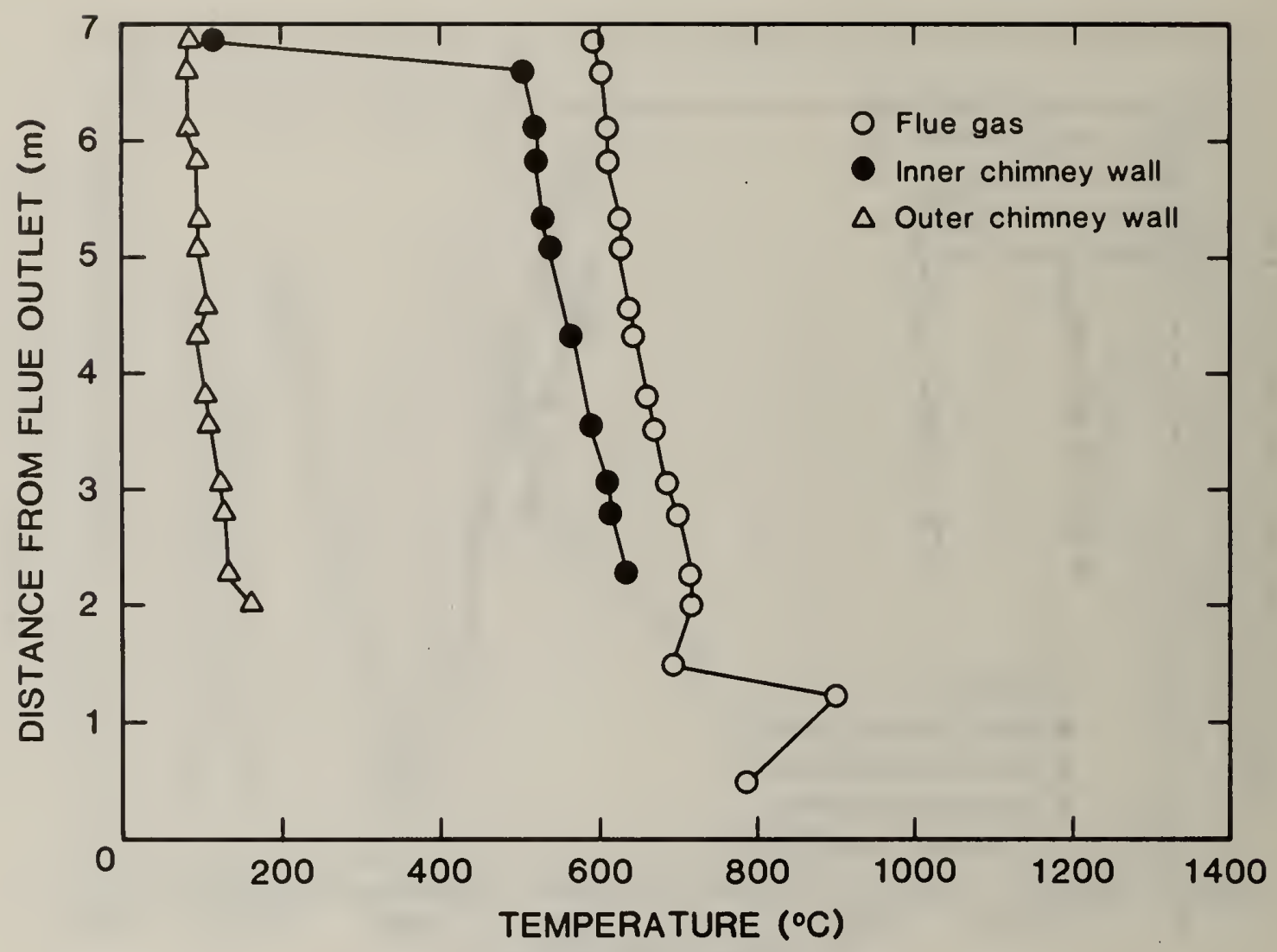

Figure 59. Temperature Profiles During Overfire Test of Chimney 5. 


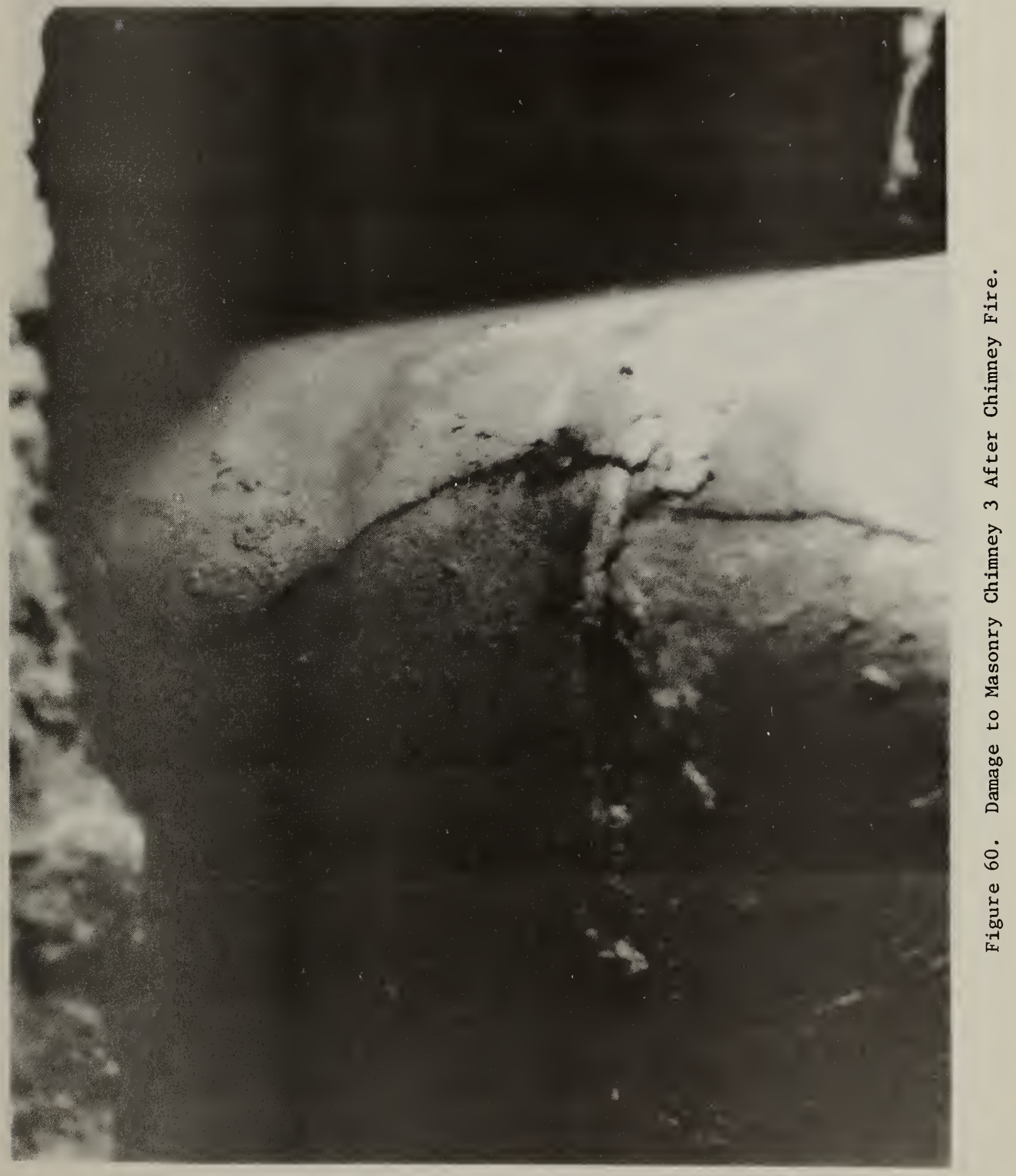




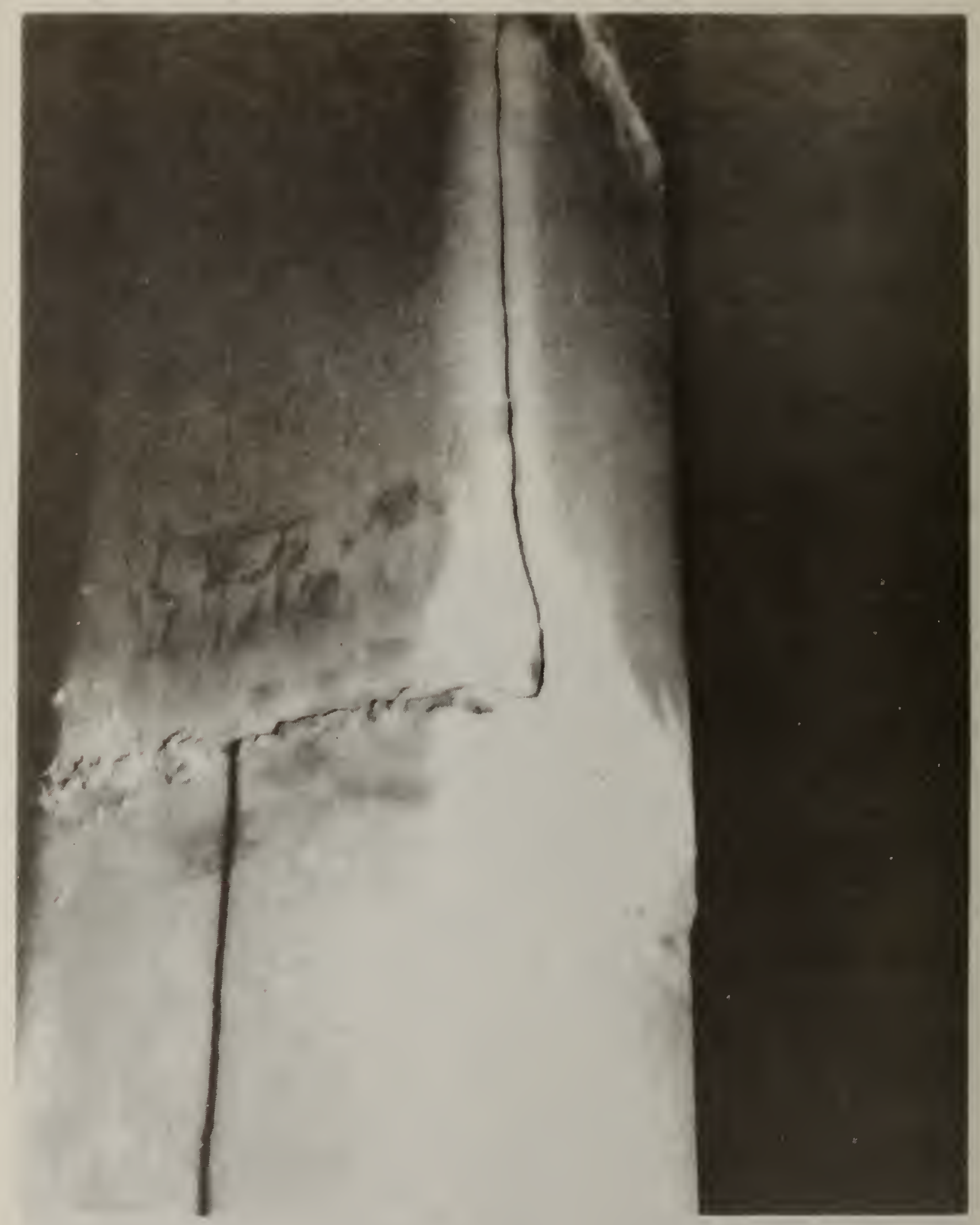

Figure 61. Damage to Masonry Chimney 3 After Chimney Fire. 


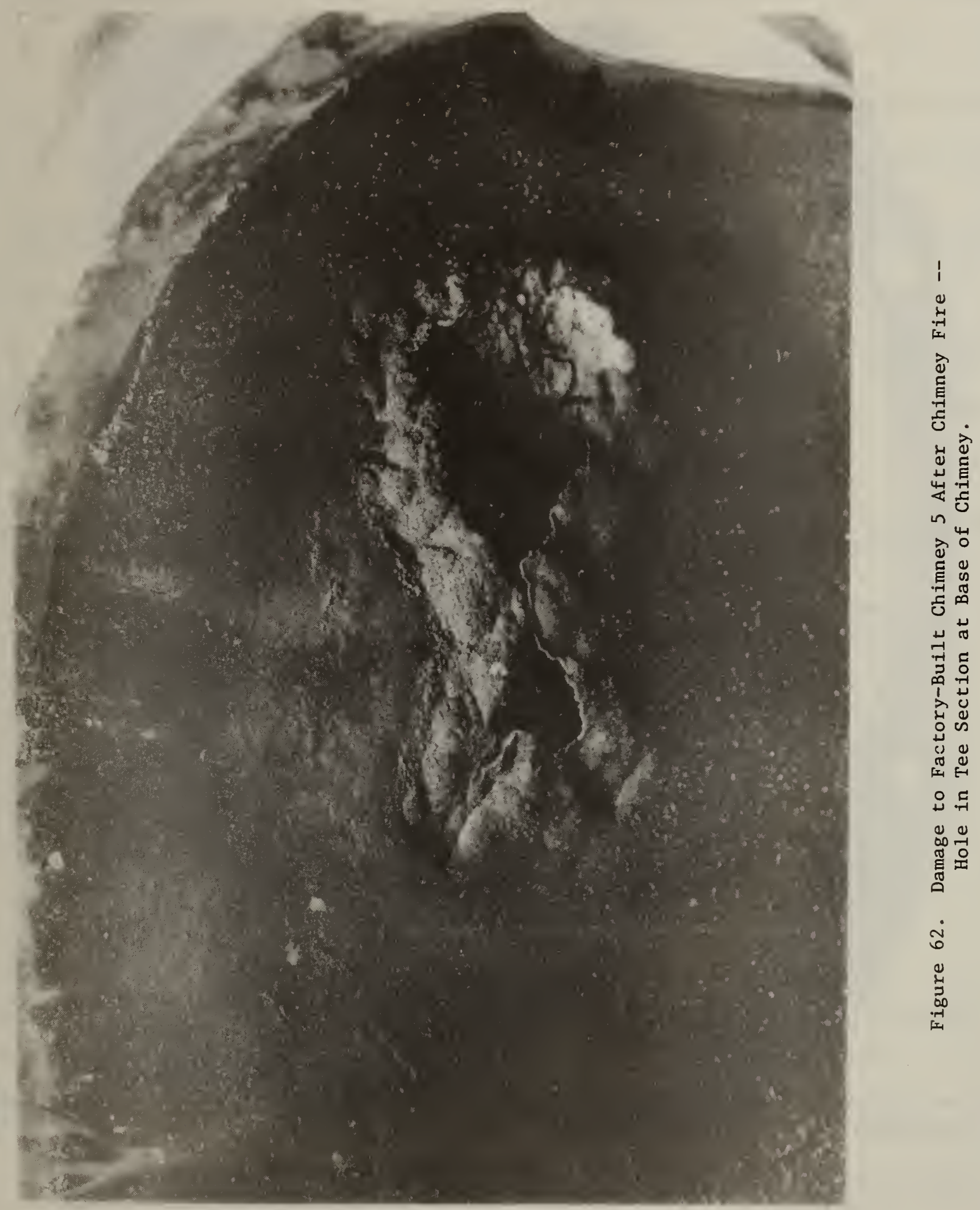




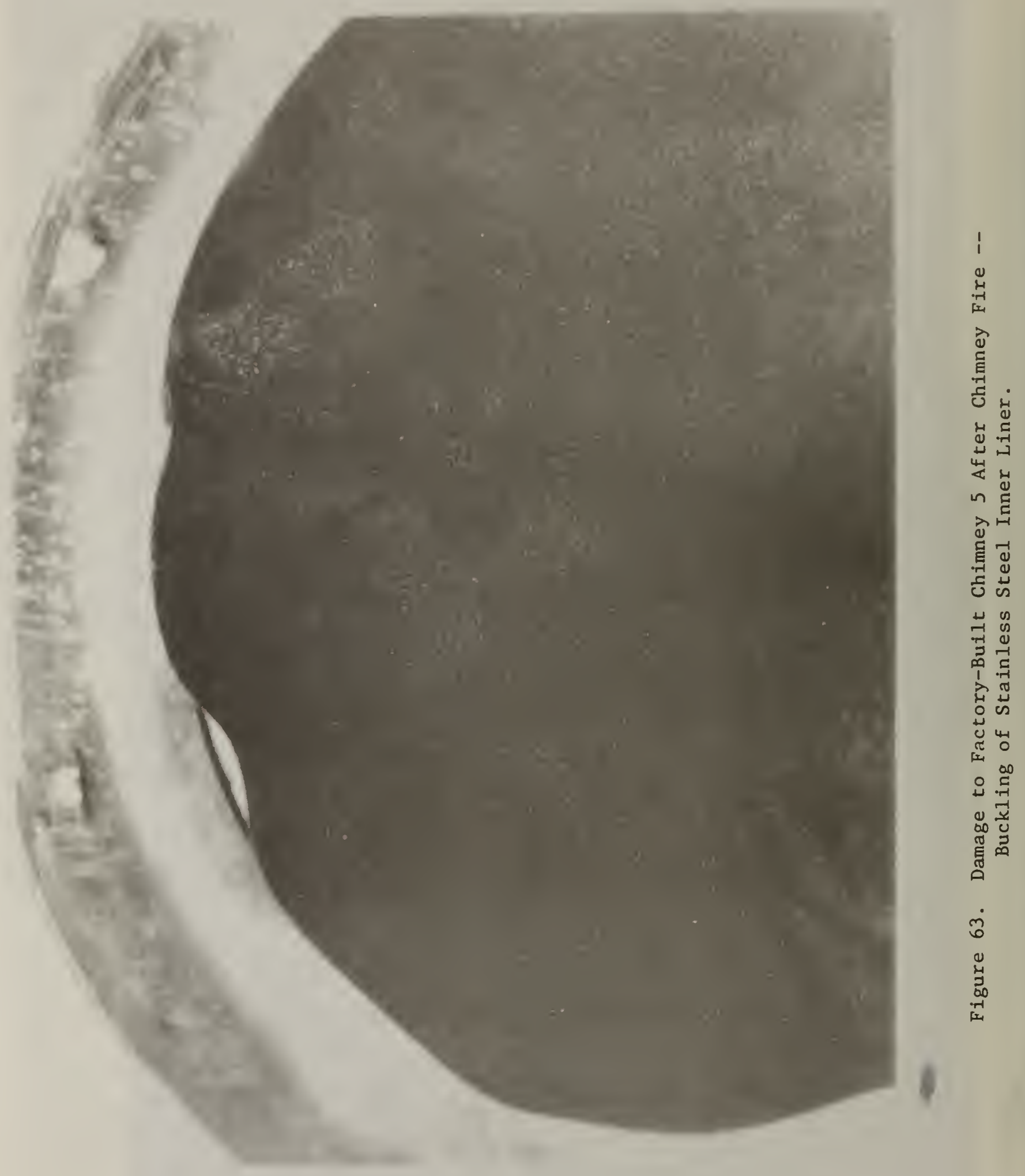


Intensity and Duration of Chimneys Fires in Several Chimneys

5. AUTHOR(S)

Richard D. Peacock

6. PERFORMING ORGANIZATION (If joint or other than NBS, see instructions)

7. Contracu Grant No.

NATIONAL BUREAU OF STANDARDS

DEPARTMENT OF COMMERCE

WASHINGTON, D.C. 20234

8. Type of Report \& Period Covered

Final

9. SPONSORING ORGANIZATION NAME AND COMPLETE ADDRESS (Street, Clty, Stote, ZIP)

U.S. Department of Energy

Washington, DC 20545 and
U.S. Consumer Product Safety Commission Washington, DC 20207

10. SUPPLEMENTARY NOTES

Document describes a computer program; SF-185, FIPS Software Summary, is attached.

11. ABSTRACT (A 200-word or less factual summary of most significant information. If document includes a significant bibliography or literature survey. mention it here)

A series of tests was conducted in four instrumented chimneys to study the intensity and duration of chimney fires due to the ignition and burnirig of combustible deposits accumulated on the chimney lining over a prolonged period of time. These tests were conducted (1) to establish typical conditions including temperatures in the chimneys and on combustible surfaces nearby, (2) to determine the duration of the burnout as evidenced by elevated temperatures within the chimneys, and (3) to compare these measured values with those obtained during overfire conditions - prolonged firing of the appliances at high rates.

The results of these tests point out some areas where the the codes and standards covering residential wood heating appliances should be modernized to better protect against failure due to chimney fires.

12. KEY WORDS (Six to twelve entries; alphabetical order; capitalize only proper nomes; and separate key words by semicolons) Chimney fires; chimneys; creosote; fire safety; fire tests; flues; heating equipment; stoves; wood.

XX] Unlimited

$\square$ For Official Distribution. Do Not Release to NTIS

$\square$ Order From Superintendent of Documents, U.S. Government Printing Office, Washington, D.C. 20402.

14. NO. OF

PRINTED PAGES

135

15. Price

[X] Order From National Technical Information Service (NTIS), Springfield, VA. 22161 


